MA K I NG

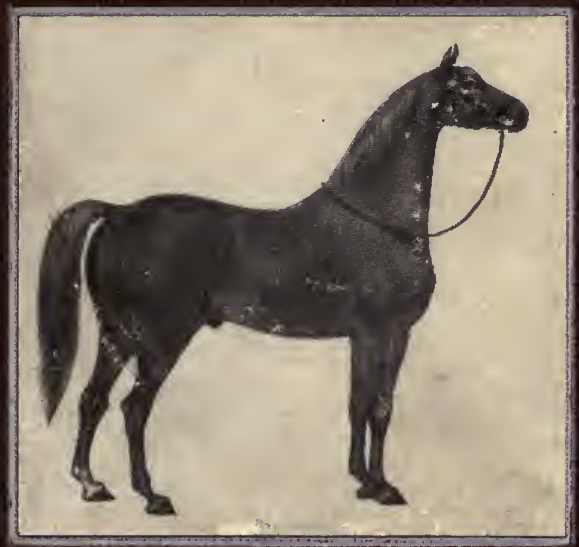

T H E

AMERICAN

THOROUGHBRED

JAMES DOUGLAS ANDERSON 


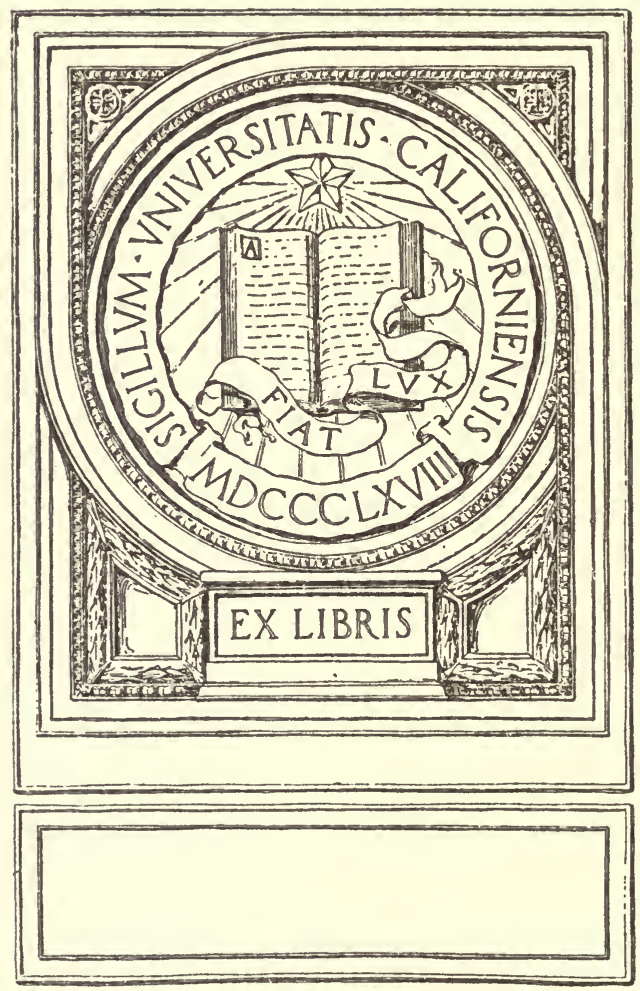



1 
MAKING THE AMERICAN THOROUGHBRED 
"Every age and every nation bas certain cbaracteristic vices, wbich prevail almost universally, wbich scarcely any person scruples to avow, and which even rigid moralists but faintly censure. Succeeding generations change the fasbion of their morals, with the fasbion of their bats and their coaches; take some otber kind of wickedness under their patronage, and wonder at the depravity of their ancestors." - MACAULAY.

"If I were to begin life again, I would go on the turf to get friends. They seem to me the only people who bold close together. I don't know why; it may be that each knows sometbing that might bang the otber, but the effect is deligbtful and most peculiar." - HARRIET, LADY Ashburton, to Lord Houghton. 


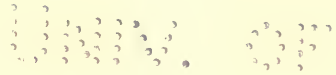

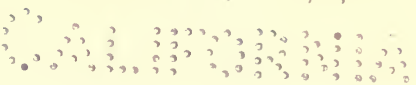




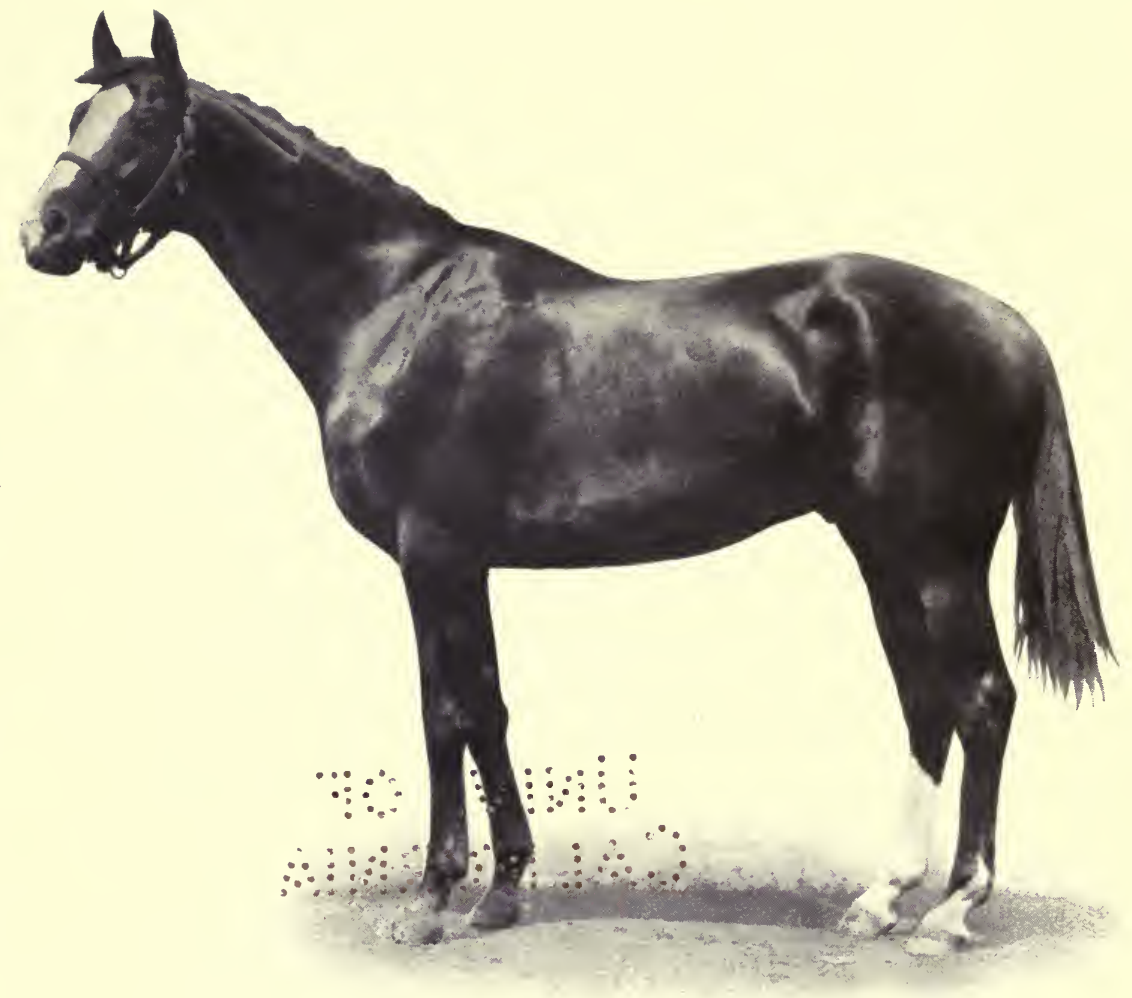

\section{GREAT BRITAIN}

Foaled, I9I0, at Edenwold Stud which embraces part of the Donelson farm where Grey Medley first stood in Middle Tennessee, in 1800 . A modern illustration of the thoroughbred made by long established methods set forth in the succeeding pages. See pages $94,287$. 


\title{
MAKING THE AMERICAN THOROUGHBRED
}

Especially in Tennessee, 1800-1845

\author{
BY \\ JAMES DOUGLAS ANDERSON \\ 11 \\ INCLUDING \\ REMINISCENCES OF THE TURF \\ BY \\ BALIE PEYTON \\ WITH NOTES BY THE AUTHOR
}

PRINTED BY

THE PLIMPTON PRESS, NORWOOD, MASS.

1916 


\section{$5 F 291$ A6}

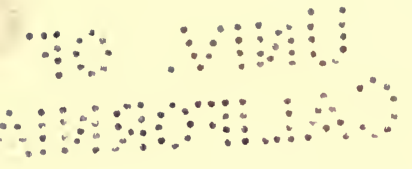

C OPY R IG H T, I9I6, в Y

JAMES DOUGLAS ANDERSON

PRINTED FOR THE AUTHOR BY THE PIIMPTON PRESS, NORWOOD, MASS. 
TO

MR. WALTER O. PARMER

WHOSE GENEROUS ASSISTANCE MAKES POSSIBLE

THIS BOOK

IT IS RESPECTFULLY DEDICATED 



\section{THIS BOOK AND BALIE PEYTON}

THE original purpose of this volume was to show the extent to which the raising and racing of thoroughbreds was carried on in Tennessee during the first half century, or more, of the State's existence.

Investigation developed that the breeding and turf interests of Tennessee were so interwoven with these interests in other states, the scope of the volume had to be enlarged to the point indicated by the title.

Most books about thoroughbreds of the period considered here are devoted chiefly to the science of breeding and methods of training and to the physical well-being of the horse, and are of interest only to horsemen. This volume endeavors to emphasize the effect that all these theories and experiments had on the customs and habits of the people.

The labor system, the code duello, the religious campmeetings and the open-house hospitality, of the "antebellum" South have aII been given their just share of attention by historians. But the origin, growth and extent of the thoroughbred industry have not, as far as I have observed, received any consideration whatever by any book purporting to treat of life in any Southern state.

In this volume will be found material upon which the historian of the future may base a chapter on "The America of Sir Archy," or "The Tennessee of Leviathan," that will rival in interest Green's chapter on "The EngIand of Shakespeare." In the absence of available facts 
to support such a chapter it would not be credited. Hence the details.

In all the literature of the period under consideration it appears that the then widespread interest in the thoroughbred was largely due to the generally known record of distinguished ancestors, both in America and England, on the race course, and in the stud. It is, therefore, necessary, in order to know the thoroughbred as our antebellum forefathers knew him, to present him not alone as an individual, separate and apart from others, but as the representative of a line running back through many years of honorable achievement. Both the subject matter and the index have been prepared with special reference to this point; and the accomplishments of all the principal progenitors in America and England, of almost every horse named in this volume, may be easily ascertained and the meaning of a pedigree fully understood. Interest in these pedigrees will be enhanced by the illustrations of noted foundation sires, among which the most prominent American families of the post-Revolutionary and Iater periods are fairly represented.

In the matter of pedigrees I have consulted Weatherby's English Stud Book, Joseph Osborne's (English) Hand Book and Breeder's Guide; and American Stud Books by Edgar, Skinner, Wallace and Bruce; also certifrcates contained in advertisements not accessible to any of these authors. All the material differences found in the statements of pedigrees in these publications are duly noted. By using the same source of information - newspaper advertisements - from which hundreds of ancient pedigrees have been collected into stud books, I have added to the list of stallions that stood in Tennessee many names not mentioned in any other volume. The body of the book, I think, will show the extraordinary 
care I have taken to avoid errors, which the duplication of names and the mistakes of other writers make it almost impossible to escape.

Whatever may be the demerits of the book I claim for it the fruits of original investigation. No one of the six stories I have written is in any sense a re-hash of any other account in any publication similar to this. In collecting material I have been rendered great assistance by many persons in various sections of the Union, to aII of whom I express my deepest gratitude. Among this number are Capt. B. M. Hord, Maj. George B. Guild, Hon. J. W. Byrns, Dr. John M. Bass, and Messrs. Percy Kinnaird, John H. DeWitt, W. E. Beard, R. C. Brien, Robert Dyas, M. L. Lewis, Clark Kirkman, Franc M. Bath, John Donelson, and Calvert Brothers, photographers, all of Nashville; Dr. J. C. Baker, Col. J. B. Malone and Mr. Harry Franklin, of Sumner County; Mr. Duncan Kenner Brent, of Baltimore; Mr. James P. Needham, of Washington, D.C.; and Messrs. H. M. Lydenberg and V. E. Schaumburg of New York. Mr. C. R. Kilvington, of Nashville, and Mr. B. A. Rowe of the Plimpton Press, have been of valuable aid in advising as to the details of manufacture. There is one other whose influence is most manifest by what does not appear in the book; but for fear that what remains of my inferior capabilities should be accepted as the full measure of her judgment and superior attainments it is perhaps best that I should not call her name.

Of Hon. Balie Peyton, whose pen and predilections for the turf have given to this volume many interesting features, it is appropriate that I should speak. The record of his public services has been written in several books and need not be followed here in detail. He was lawyer, orator, diplomat, statesman, patriot, soldier, breeder and 
turfman. His most notable gift was that for public speaking; his most prominent traits integrity, affability, courage and kindness; his strongest passion love of country; next to that, love of a race horse; and next to that, love of a horse race.

In his first campaign for Congress he practically won his election by his opening speech; at the end of his second term, in 1837, he voluntarily retired; and although he was but 34 years old he had distinguished himself throughout the Union as an orator, and as a leader, bold in initiative and inflexible in execution. Personally, there was not a more popular man of his day.

In dedicating one of his publications to Peyton, J. S. Skinner said of him: "He is in his own spirit and character exemplary of what is best and most excellent in men."

"Few lives," wrote one of his fellow townsmen, "have exhibited more of the excellencies of human character and fewer short comings than did the life of Balie Peyton."

"He had a richly gifted intellect," wrote another of his contemporaries, "but his heart seemed always greater and deeper than his mind. Free from all jealousy, he gloried in the triumphs of his political and personal associates and was always exuberant in heralding their achievements, while apparently forgetting his own." In his "Reminiscences" he did not exploit his own achievements, and turf literature is much the poorer by his modesty.

In several Presidential campaigns his talents for public speaking and statesmanship were drafted into service in many states North and South.

In New Orleans, he was made President of one of the Jockey Clubs. Four Presidents of the United States, by tendering him appointments, attested to his character 
and ability. Tyler asked him to become Secretary of War, but the position was not to his liking. When war came with Mexico, however, he did not wait to be asked to go to the freld of action. There he became Chief of Staff of Gen. W. J. Worth, after his own regiment of Louisiana and Alabama men had been recalled by President Polk. At Monterey it became necessary for Gen. Worth to communicate with General Taylor on the opposite side of the city, and Peyton was chosen for this errand. Mounted on a thoroughbred by imp Fop, presented to him by his friend, Lucius J. Polk, Peyton, though continually under fre, his horse bounding at the bursting of each shell near him, performed the trip at a dead run and in safety. For this and other acts showing his courage and effrciency he was favorably mentioned in Gen. Worth's reports and was voted a sword of honor by the State of Louisiana. With modesty and true sportsmanship he always credited the success of his trip to his horse.

In March, 1837, after the adjournment of Congress, Peyton came home by way of Richmond, Virginia, his purpose in going there being to see Priam who had just arrived from England. From Nut Bush, North Carolina, he wrote The Spirit of the Times an account of this trip. On the way out to the farm where he thought Priam was, he met a stranger, whom he felt convinced was the man he was on his way to see. He "inquired and it turned out to be so, which proves that one thoroughbred horseman will know another, as Falstaff knew the true Prince." Peyton introduced himself, only to learn that Priam was at the Half-Way House, between Richmond and Petersburg. Back to Richmond he went and in half an hour was on his way to the Half-Way House. Upon reaching Priam's stable, "I approached," he said, "and while the door was unlocking felt that painful anxiety, arising from the apprehension of disappointment, - of not realizing 
those expectations which we feel on being ushered for the first time into the presence of the great - of those of whom we have read and heard. But the first impression was a pleasing relief from all such fearful forebodings. Priam is a rare instance of a great name bearing acquaintance without losing 'the enchantment which distance lends.' How few great men there are of whom this can be said! No judge of form who saw him would wish to go to books and racing calendars to learn his superiority as a race horse. There it is before you - a plain case - written in old English characters too legibly to be misunderstood." After discussing at length the many points of merit in the horse Peyton closed his communication thus: "In fine I can say that taking him all in all I have never looked upon his like before and never may again, unless he is destined to leave a son who will -

'Rise the Hector of the future age,

So, when triumphant from successful toils,

Of heroes slain, he bears the reeking spoils,

Whole hosts may hail him with deserved acclaim,

And say this chief transcends his father's name.'

"This fellow I mean to rear myself, and to silence all dispute I claim the name in advance: Hector b.c., got by Priam, out of — ; raised by yours,

$$
\text { "P. of T." }
$$

This resolution Peyton did not forget three years later when he named his entries in the Peyton Stake.

After leaving Congress in 1837, Peyton was absent from Tennessee, except on occasional visits, until 1859 . During all that time he kept up his thoroughbred business, under the management of his brothers, Holmes and "Ran"; after they died, his son, Balie, assisted by Judge Thomas Barry, looked after the horses. 
During the war, when the master himself had control, he heard the Federals were headed his way, and he knew what their coming would mean to four of his highly prized colts. Removing the furniture and carpet from the dining room, and putting in a thick layer of straw, he had the colts led in, the doors locked and the windowblinds barred. In this way he saved them from the marauders, but they got his favorite brood mare, Noty Price, by Cost Johnson, son of Boston. One of these colts, Blacklock, afterwards distinguished himself.

Because of his opposition to secession and his neutrality during the war, Peyton was able to render valuable services to his Sumner County friends by standing as a strong rock between them and the Federal General, Payne. Among others, his neighbor, Rev. B. F. Ferrill, of the M. E. Church, South, was released from jail through his instrumentalities. One who was present when Peyton called on Payne in behalf of an excellent woman who had appealed to him for protection, is authority for the statement that if Payne had not then yielded to Peyton's demand for the woman's release, there would have been no diplomatic postponement of affirmative action on his part.

In 1869-70 Sumner County sent Col. Peyton to the State Senate, to use his influence in bringing order out of chaos. Later he took an active part in promoting the Philadelphia Exposition of 1876 , confident that it would tend to obliterate sectional animosities. Perhaps his last public address was delivered by invitation before the Tennessee legislature in furtherance of this patriotic movement.

Col. Peyton had now passed threescore years and ten and the sand in his glass was running low. The passing of the old order had brought new alignments in political, 
Iegal and business circles; new problems that demanded the best energies of younger men who must need build for the future. This is the heaviest penalty age has to endure. Others had paid it to Peyton, and now when younger men exacted it of him, he yielded with good nature and becoming grace. And it would seem, that during all the years of his absence in other lands he had not forgotten that the time would come when, in the race with younger competitors, he would have to pull up outside the distance and retire. At any rate, it was his good fortune, such as comes to but few men, to spend his declining years amidst the scenes of his earliest associations. Followed always by a pack of hounds, he walked, or rode his favorite saddler, a gray, through the frelds and woodlands where for nearly half a century his horses had grazed; and here he dwelt with pleasant retrospection on their qualities and the incidents they had brought into his life.

Pupils who attended his daughter's school at Station Camp at this period still retain vivid recollections of the kindness and consideration that convinced them that Col. Peyton was the greatest man in the world.

But there were stronger ties than these that bound Peyton to this land which his father, a Revolutionary soldier, had won from the savage. It was his birthplace, his first play ground. It was here that he first heard the stories of Revolutionary and Settlers' wars, that fired his young heart with a desire to serve his country. Here he had lived the first years of his married life; here his children had spent their infancy; and here, after his elections to Congress, he had received the plaudits of admiring friends.

But the old home place was not without its sorrowIaden memories. Here, on Christmas Day, a young 
daughter had met a violent death. Here he had presented to young Balie the Louisiana sword, and had bid him farewell and gazed after him with tear bedimmed eyes as he rode away to join the Confederate army, never to return. Thoughts of these events were ever in his mind, but they only tightened the cords that bound him to Station Camp. It was, indeed, good fortune that he, the last leaf upon a tree, should fall on soil consecrated by cherished recollections of the past. In midsummer, when the harvest was ripe, he was cut down, and his friends and neighbors who loved him because he was a good man, came and put him away under the sod over which he had played when a barefoot boy.

J. D. A.

Madison, Davidson County, Tennessee.

February 6, 1916. 



\section{CONTENTS}

CHAPTER

PAGE

I. Speaking Generally. . . . . . . . . . . . . I

II. English Aristocrats . . . . . . . . . . . . 18

III. First Families of Virginia . . . . . . . . . 30

IV. Hardy Tennessee Pioneers . . . . . . . . . 42

V. Knee Deep in Clover. . . . . . . . . . . . 66

VI. Sumner County, Breeding Centre . . . . . . . 96

VII. Tennessee and North Alabama . . . . . . . . . II4

ViII. Getting Their Money Back. . . . . . . . . . . 129

STORIES OF EIGHT FAMOUS RACES:

American Eclipse vs. Henry . . . . . . . . . . IgI

Post Boy vs. Јohn Bascombe. . . . . . . . . . . . . 164

Angora vs. RodolPh . . . . . . . . . . . . 175

The Leviathans $v s$. The Luzboroughs and Others . . . 184

The Peyton Stake . . . . . . . . . . . . 194

Fashion vs. Peytona . . . . . . . . . . . . . . 208

The Race of the Old King . . . . . . . . . . . . 219

A Diplomat in Pigskin . . . . . . . . . . . 224

REMINISCENCES OF THE TURF (PEYTON):

I. Green Berry Williams Begins His Career . . . 23i

II. Williams' Virginia Career . . . . . . . . . 235

III. Sumner County Races, 1804-05 . . . . . . . . 239

IV. President Jackson's Orders and Reminiscences . 243

V. Williams' Tennessee and Mississippi Campaigns 248

VI. Walk-in-the-water, A Remarkable Racer . . . 253

VII. Haynie's Maria Against the World . . . . . 258

ViII. Tennessee Oscar, A Horse Without a Rival . 266

Appendix: Letters from Andrew Jackson to Rev. Hardy M.

Cryer . . . . . . . . . . . 27I

AdDENDA . . . . . . . . . . . . . 275

INDEX . . . . . . . . . . . . . . 289 



\section{ILLUSTRATIONS ${ }^{1}$}

PAGE

Sir Charles . . . . . . . . . . Cover Design

Great Britain . . . . . . . . . . Frontispiece

The Darley Arabian, The Godolphin Arabian . . . . . 20

Flying Childers, King Herod . . . . . . . . . . . . . . 32

Matchem, O'Kelly's Eclipse . . . . . . . . . . . . . 44

Highflyer, Gimcrack, Imp Citizen . . . . . . . . . . . . 68

Imp Diomed, Sir Archy . . . . . . . . . . . . . . . . . 98

Timoleon, American Eclipse . . . . . . . . . . . . . II5

Imp Leviathan, Imp Glencoe . . . . . . . . . . . . 130

Rev. Hubbard Saunders, William Williams, Montgomery Bell I43

Andrew Jackson, William R. Johnson, George Elliott . . . . 152

John Bascombe, Boston . . . . . . . . . . . . . ${ }_{166} 66$

Lucius J. Polk, Hugh Kirkman, Andrew J. Donelson . . . . 176

James Jackson, Rev. Hardy M. Cryer, W. G. Harding . . . . 186

Jesse Cage, Jo C. Guild, Balie Peyton . . . . . . . . . . 196

Fashion, Sir Henry Tonson, Imp Priam . . . . . . . . 210

Wagner, Grey Eagle, Lexington . . . . . . . . . 220

1 See Addenda A. 


\title{
MAKING THE AMERICAN THOROUGHBRED
}

\author{
ChAPTER I \\ SPEAKING GENERALLY
}

"BEING in the midst of the winter's blast," wrote Gen. Robert Desha, of Sumner County, to the New York Spirit of the Times, on February 8, 1839, "there is nothing doing with us as regards that manly and gentlemanly amusement, the sports of the turf, to which Sumner County, from the earliest period has been and continues to be so much devoted. Every week brings us your valuable sheet, which is a rich delicacy amidst the common fare of our table. Like the old soldier we sit by the fireside and talk of comrades of other days; the battles they have fought and victories won. We talk of those now on the freld and those who are to come after them. In these discussions we exhibit the feelings common to man when we maintain that our county, Sumner, has produced, is producing and will continue to produce as good and as many race nags as any county in the United States."

"This, I suppose, is the acknowledged centre of the race horse region," wrote William Giles Harding from Belle Meade to The American Turf Register, on June II, 1839. "Blood stock here is all the go. To be without it 
is to be out of fashion and destitute of taste. So I, too, have procured a little of the real grit which by-and-by I hope to increase."

This thoroughbred industry had come to Tennessee from Virginia and the Carolinas - principally Virginia where it had flourished since pre-revolutionary days from the same causes which later made it "all the go" in Tennessee and other Southern and Southwestern States.

The English thoroughbred was a discovery - the result of scientific experiment. His speed and agility and his ability to stand heat and hard service, though weighing only about eight hundred pounds, attracted the attention of scientists, both in England and the United States, to his anatomy, especially to the solidity of his small bones and muscles and to his lungs, neck and shoulders. His value as a commercial asset was quickly perceived. He fit into the needs of the times and his importation into Virginia was based on business necessity and economy and was in the natural order of events.

When not engaged in the library, or in some public assembly protesting against British oppression, Colonial Virginia lived out of doors. Fox hunting was a popular sport; the thoroughbred was the very thing for the chase. In harness and under the saddle he solved the problem of rapid transit in ease and comfort. For overland travel he was the fastest medium known. Throughout a period when cross-country trips, forty, fifty, or a hundred miles, to visit friends or attend political or religious conclaves were of daily occurrence, the thoroughbred was considered as indispensable as all other more rapid means of conveyance have been regarded since. Practicing lawyers and judges on their circuits, pastors and elders on their rounds and bishops on their annual visitations found in him continual pleasure; not the least 


\section{Speaking Generally}

part of which sprung from a feeling of companionship so common to horse and rider on long journeys through nature's heart. With both young men and young women in the young South horseback riding was a fashion and an art long since displaced. In seeking to checkmate his rival who rode a thoroughbred the gallant who did not was apt to win no greater stake than an invitation to his own "funeral." No creation of man's ingenuity in devising means of transportation has ever excited greater popular interest or wrought a greater or more beneficent influence upon the customs and habits of the people. What the half-tone is to literature the thoroughbred was to the entire social fabric. He raised existence above the humdrum and the commonplace. He gave a new meaning to life - a new reason for sunshine and green grass.

To determine the best stock to breed from, tests on the race course were deemed necessary. "We can only judge correctly of the intellectual and moral worth of our great men when we view them on the world's stage in competition with distinguished competitors," said Gen. Harding. "Without a theatre the world could never have known those distinguished delineators of human character whose names now fill many an honored page in human history. Without a race course the breeder could not know the superior horses and the best strains to propagate, and without this knowledge his improvement would cease and deterioration begin. The race course is a necessity." This was the view of breeders generally, from the foundation of the industry in the United States, and the same rule has always prevailed in everything from cabbages to kings.

In these tests of individual types and families, with the view of propagating the best stock, competition and rivalry between owners, communities and states as to the 


\section{$4 \quad$ Making the American Thoroughbred}

respective merits of certain individuals and strains of blood was inevitable. Thus, it was reported in the 1830's that the controversies then going on in Kentucky between the "friends" of Medoc and the "friends" of Woodpecker, and, in Tennessee, between the partisans, respectively, of Luzborough and Leviathan, were as intense as were the controversies between the Whig and Tory parties of olden time. These rivalries furnished several generations that had no exciting pastime except war and hunting, the "manly and gentlemanly amusement, the sports of the turf."

For be it remembered that in all ages and in all climes men will have diversion from their daily routine. The native Hawaiian who, standing erect on a plank, rides the waves for a mile, into shore, is controlled in his inbornlove of excitement, risk and adventure, by his environment; but not less so than were the people of the South who, before the appearance of modern sports, found on the race course an opportunity for recreation based upon business necessity and economy and attended with that uncertainty of results which exhilarates every human endeavor - in war, in politics and in all commercial and professional pursuits. The race course was the natural product of conditions - as much so as the cotton gin and the slave trade. Indeed, it would have been very remarkable under conditions then existing, if horse racing had not become the great national amusement.

Prior to the Revolution, an old chronicle tells us, "races were established almost at every town and considerable place in Virginia: when the inhabitants almost to a man were devoted to this fascinating and rational amusement: when all ranks and denominations were fond of horses, especially those of the race breed: when gentlemen of fortune expended large sums on their studs, 


\section{Speaking Generally}

sparing no pains or trouble in importing the best stock and improving the breed by judicious crossing."

Under these circumstances Virginia, between 1758 and I 790, produced the best race horses, the best driving horses and the best saddle horses known in her history. So, long before Virginia became the Mother of Presidents she was the dam of the thoroughbred that presidents could not withstand. Here Jefferson and the Murat of his administration, Randolph, met Washington and Henry Clay on common ground. Nor was the United States Supreme Court, nor the Army, nor the Navy, immune against attack of this fecund sporting germ. Racing was the sport of kings. And where kings lead deuces always follow: in politics, religion and corner groceries it is even so.

It was the spirit of rivalry above alluded to, added to the commercial necessities of the times, that made the thoroughbred the "fashion" in Colonial Virginia and paved the way for his introduction into the western country by an immigrant population from the older states. The thoroughbred moved westward with the star of Empire as fast as conditions permitted. The interest aroused in "that manly and gentlemanly amusement, the sports of the turf" in Middle Tennessee was not due to the creative influence of any one individual, as many suppose; it was in the atmosphere then, as the automobile is now, and it followed the emigrant wagon from Hanover's slashes to the Rio Grande.

In promoting their industry Tennessee breeders, as well as those of other states, in the 1830's, were wont to tell of the thoroughbred's superior qualifications for war. They pointed to several European conflicts - the invasion of Europe by the Turks and their subsequent invasion of Italy - in which the Turkish progenitors of the Eng- 
lish thoroughbred made the Turkish cavalry invincible although opposed by trained and disciplined troops. The efficient aid rendered by Light Horse Harry Lee's cavalry to Gen. Greene, in time of stress, was made possible by the speed and endurance of the thoroughbred. In the Florida wars it was demonstrated that he could stand heat and hardship better than a mule and live on less. While scrubs died by the hundreds every son of Pacolet and Tennessee Oscar and other. Tennessee thoroughbreds came through in good condition and was turned back to the Government at Tampa Bay.

These views were more than confirmed a quarter of a century later. "Never did blood tell with more effect than in the beginning of the late Civil War when the successes of the Southern cavalry proved more than equal to the North, two to one. But towards the close of the war when the well-bred horses of the South feIl into the possession of the Northern cavalry this superiority failed to appear. A thorough scrub is incapable of either speed or endurance."

In this opinion, expressed by Gen. W. G. Harding, exConfederates and ex-Federals, generally will concur.

Gen. Forrest had similar views. In his pursuit and capture of Gen. Straight he demonstrated the superiority of the thoroughbred over the draft horse of the North. Gen. Morgan owed his escape on one occasion to Black Bess, a Kentucky thoroughbred, and her celebrated 20-mile run from Lebanon to Carthage, under a burning sun. The wonderful achievements of Stuart's cavalry would have been impossible without the use of thoroughbreds. Success and life itself often depended upon the slender thread of a pedigree.

From Tennessee the thoroughbred industry passed on to North Alabama where it secured a strong hold. It 


\section{Speaking Generally}

did not obtain to a great extent in the far South, but here the fortunes made out of cotton and sugar enabled the racing branch of the industry to be developed more extensively than anywhere else in the Union except, perhaps, in Charleston, S.C. Brood mares that were owned in the far South were generally kept in North Alabama or Tennessee but their foals were reared on the plantations of their owners. The number of these, how ever, was insufficient to meet demands of the high lords of the low country whose racing centre was New Orleans, "the Newmarket of the South." The winter race meetings at her three courses - Louisiana, Metarie and Eclipse - drew people from everywhere as the Mardi Gras did in more recent years. This had an important bearing upon the breeding industry of Tennessee. Nearly every good horse bred in Tennessee was eventually purchased for running in Mobile, Vicksburg, Natchez and New Orleans and other far Southern points. One hundred thousand dollars was paid for horses to run in New Orleans in December, 1837.

"The prevailing opinion in the South," wrote Lewis Sanders, a prominent breeder of Gallatin County, Kentucky, in 1836, "is that Tennessee possesses more and better blood than Kentucky. Tennessee stock will fetch more money in the South than ours will. . . . At the races two years ago, at Louisville, Tennessee stock had rather the advantage, though we beat them the 4-mile day with a Kentucky-bred horse."

This preference of the South for Tennessee stock continued. At the three New Orleans courses, on twenty days in December, 1838 , there were 62 entries (44 horses) in the 25 races that were run. Thirty-one ( 17 horses) of these 62 entries were got by (or were out of dams by) one of the horses named in the list (in this volume) of 
stallions, that stood in Tennessee. In several instances both sire and sire of dam were of this Tennessee stock. The number of individuals and entries by Leviathan exceeded the number by any other horse. Notwithstanding this showing Kentucky produced many fine horses and in September, 1839, 250 thorough-breds were said to be in training in that State.

On the turf, then, as in National politics, Tennessee was a pivotal State. Her race horses were not less famed than were her statesmen, her orators and her preachers.

As the thoroughbred came to establish a distinct type of work horse in the South, he also created a distinct type of mule. His fatigue-proof and heat-proof qualities were a heritage from his Arabian ancestors. When this blood was transmitted to the stronger mule - as was first done in the colonies - it made him incomparable for the Southern plantation - Ioo per cent efficient. In this way he contributed greatly to the growing of tobacco, rice, cotton and sugar, the greatest wealthproducing, mansion-building products of the South. Tennessee being a thoroughbred centre the production of mules for the Southern market came naturally out of the thoroughbred industry. Many Tennesseeans owned cotton and sugar plantations and supplied them with mules from Tennessee throughbred mares. Isaac Franklin, for instance, used Fairview in Sumner County, as a base of supplies for his several Louisiana plantations.

Out of this thoroughbred industry, also, the trotter came by process of evolution - a fact too well known to require extended mention. But it may not be well known that the superiority of the thoroughbred horse gave an impetus to, if it did not originate, the importation of -thoroughbred cattle, sheep and hogs. As admitted in the North, the South was far ahead of the 
North in improving other farm animals by thoroughbred importations.

Instances: in the same ship that landed in New Orleans December, 1838, with thoroughbred horses for Thomas Alderson of Nashville and Lucius J. Polk of Mt. Pleasant, Thomas Flintoff, a race horse man of Williamson County, brought over eight prize sheep; and Cassius, a Durham bull, that was immediately sold to L. J. Polk of Mt. Pleasant and James Jackson of Florence, Ala., for $\$ 5,000$. About the same time, at an auction sale of John H. Clopton's stock, near Nashville, J. W. Clay, a race horse man, Proprietor of Bellair, on the Lebanon road, and son-inlaw of John Harding, paid $\$ 700$ for a Durham cow; and H. P. Bostwick, of Williamson County, paid $\$ 626$ for her yearling calf. About this same time, also, Henry Clay Jr., of Fayette County, Kentucky, sold a cow to some of his neighbors for \$2,000; Thomas H. Clay paid \$700 for a 2-year old Durham bull and William P. Curd of Fayette County, Kentucky, paid $\$ 500$ for a pair of Berkshire hogs.

Out of the popular interest thus aroused in all sorts of pure blooded stock grew agricultural shows and county fairs known in Tennessee in 1836 , if not before. It was the spirit of the times, brought on by the thoroughbred horse, that caused Mark R. Cockrill, a Davidson County farmer and breeder of race horses, to capture premiums for the best Merino wool at the London Fair in 1851 . Of the more than 100 race tracks, in the United States, each under the jurisdiction of its own Jockey Club, at which races were known to a contributor to The Turf Register to have been run in 1839, it was said by this contributor that New Jersey had 4 tracks, New York I, Pennsylvania I, District of Columbia I, Maryland 3. Virginia 13, North Carolina 6, South Carolina 10, Georgia 5, Alabama 10, Mississippi 8, Louisiana 8, 
Arkansas 4, Tennessee io, Kentucky 17, Texas 2, Florida I, and Missouri, Illinois, Ohio and Indiana 6. Usually two, and often three, meetings of from 2 to 6 days were held each year at each of these tracks. Besides, there were many tracks without organized Jockey Clubs, and tracks from which no reports were made.

Of the I6o public stallions (thoroughbred) whose locations were known to the general public in 1839,37 stood in Tennessee, 36 in Kentucky, 23 in Virginia, 17 in Alabama, 7 in Arkansas, 6 in Georgia, 5 in North Carolina and the remaining 29 in the other states named. This list embraces nearly all of the most celebrated stallions; for the custom then was to stand them wherever their services were most in demand, and to advertise them. Still, there were others not advertised; and, in addition, there were many of equal breeding but of less general renown. Of these I6o stallions 45 were imported and I I of these 45 stood in Tennessee in the year named.

The Doncaster St. Leger - named for Lieut.-Gen. St. Leger - was established in 1776; the Oaks, at Epsom, in 1779 and the Derby at Epsom in 1780 . The Oaks, - named for the Earl of Derby's estate, near Epsom was open only to 3-year old fillies; the Derby and St. Leger to 3-year old colts and fillies alike; the entries at Doncaster, however, being confined to 3-year old winners of the six months preceding.

At the opening of the season in the spring came the Derby and the Oaks in the South, and at its close in September came the St. Leger at Doncaster in the North. The sectional rivalries common to the United States were manifest at these meetings, the people of the respective sections - North and South - backing their own horses whenever the contests narrowed down to this point. Thus, in 1836 , the South won $\$ 1,500,000$ on Elis, 
the Doncaster St. Leger winner, Lord Bentinck alone winning $£_{1} 6,000$. The "incredible sum" of $\$ 2,500,000$ was said to have changed hands on the result - almost equal to a day on a modern stock "exchange" - so called.

Between 1830 and 1840 the Doncaster St. Leger stake averaged, yearly, about $\$ 10,000$. A few years later it varied between $\$ 18,000$ and $\$ 24,000$. The sizes of the Derby and the Oaks stakes were of corresponding dignity. The honors and emoluments of these contests attracted the bluest of the blue. For sixty years, or Ionger, they formed the centre of gravitation in the English breeding and sporting world, and the supreme test of speed, endurance, blood and type. It is no wonder, then, that from the beginning, down to 1838 , the number of nominations for each of these stakes frequently exceeded 75 and ran as high as $\mathrm{I} 3 \mathrm{I}$, and that the number starting frequently exceeded 20 and ran as high as 30.

A knowledge of these facts is necessary to appreciate the progressive spirit of the Southern planter during the period under consideration. At a time when a hundred weight of cotton, a "ham of meat and a side of bacon," had to be used as a medium of exchange between neighbors, they went themselves, or sent agents, with gold, on long, tedious voyages and procured the cream of English aristocracy to use in building up the commercial interests of the South. While the best specimens of English horse flesh were contending for supremacy at Epsom and Doncaster, their brothers and sisters of the full and half blood, and other close kin, were frghting it out to the tune of "who lasts the Iongest" on the various race tracks between Beans Station and Memphis.

An instance: at the same time that many of the get of imp Priam were entered for the three great English 
stakes, eight of his get were entered for the Peyton stake and three for the Trial stake at Nashville. Three of the entries got by Priam won the Oaks and a son won the Trial stake. Other instances are given in succeeding chapters. AII together they show a spirit of enterprise not exceeded by that of any subsequent period in any line of business, in any section of the Union.

In the publications current between I830 and $1840 \mathrm{a}$ diversity of opinion, which did not exist in earlier years, is noticed with reference to the wisdom of additional importations.

The 4-miler was then playing out in England due to influences that had not yet obtained ascendency in America - and to avoid a similar fate here, many experts preferred to breed back as much as possible to the good old 4-mile stock of Jolly Roger, Janus, Morton's Traveller, Fearnought, Diomed and Medley the fountain heads of Tennessee's foundation stock.

As a general rule races were run in the Atlantic Coast States by horses owned in these states. West of the mountains the contests were between the horses of Tennessee, Alabama, Mississippi and Louisiana. Frequently ambitious owners from each of these sections crossed the barrier between them in quest of greater honors, but these were exceptional instances. Between Kentucky and Tennessee there appears to have been comparatively little intercourse. Conditions of settlement, trade and transportation, with which the reader is familiar, made Nashville and New Orleans closer together than Gallatin and Lexington, Kentucky.

Where there were organized Jockey Clubs, purses were hung up, the average value of which was about the same in all sections from New York to Texas, with New Orleans, perhaps, a shade more liberal. But these purses 


\section{Speaking Generally}

rarely if ever reached $\$ 2,000$. Generally, the highest ones ranged from $\$ 500$ to $\$ 1,000$. Sweepstakes were popular on all tracks and usually offered the greatest inducements. As with the number of the breeders, horses, and tracks, the size of the purses increased from year to year.

When neither sweepstakes nor club purses were believed to comport with the merits of a horse a challenge was issued to the whole world for a match race and an acceptance almost invariably followed. Match races between the best horses were generally for some amount between $\$ 5,000$ and $\$ 20,000$; banters were frequently made though none were accepted - to run for amounts as high as $\$ 50,000$. These contests usually involved state and sectional pride and aroused great rivalry and excitement, but did not, of themselves, arouse personal or sectional animosity. Correspondence relating to a great match race between rival leaders of the turf was always couched in terms of courtesy believed to be due from one sportsman to another. The esprit de corps was strong, even among leaders of rival states and sections. In local rivalries the crust of formalities was frequently pierced by good natured jabs, as in the following:

"To Col. Ramsey, Editor of The Knoxville Register:

"In my absence some banters have been made through the columns of your paper by Molo against Traveller, representing that if either Cashier or Traveller wanted a race with Molo they could get it for one thousand dollars, over the Red Bridge track with their appropriate weights. Now, I have no thought that Molo wants a race with Traveller; if he does and will back his statement, Traveller can beat him for any sum from $\$ 500$ to $\$ 2,000$ over any track in East Tennessee, or if Molo will come to the Madisonville track Traveller will bear his expenses three weeks. As to Molo's insinuations in regard to his training or riding, Cashier does not understand him; but there is one thing he does undersatnd, that is, that he of- 


\section{I4 Making the American Thorougbbred}

fered Molo a distance in four mile heats last Fall at the Red Bridge races, when he (Molo) was in training and Molo would not take him up.

"Traveller can beat Molo or any other covering horse in East Tennessee that has made two seasons, and served thirty mares each season (as he has done), - three or four mile heats for any of the above mentioned sums; the Race to be closed by the ist November next.

“Madisonville, Oct. 5, $1836 . "$

"William Ainsworth."

“Col. Ramsey, Sir:

“Chucky Bend, 2oth Oct. 1836.

"In your paper of the 5 th inst. I see that Maj. Ainsworth has taken upon himself personally to banter Molo with his famous time horse Traveller. I will state a few facts and then propose a race .. How do you think, Colonel, I am to get out of this banter. Molo is now ro years old and in the midst of his season. I see but one way and that is to follow the indications of your valuable paper. I see you have published in the same paper, - perhaps the second column to the left of the Major's banter, - that a steam doctor in North Carolina 'boasts that he has discovered a system by which he can make out of an old man a young man, and have enough left to make a small dog.' Now, if upon inquiry this aforesaid steam doctor can make out of an old race horse, that has been turned to the stable four years, a young one, and have enough left to make a small Jackass, I will agree to run it against Traveller, 4-miles and repeat, for his highest amount $\$ 2,000$.

"James Scruggs."

In contests involving the reputation of a state or section or family of horses, persons making the agreement usually gave each other permission to draw on the resjective states, sections, or stock involved for an individual contestant. As often as otherwise, parties issuing and accepting a challenge for a great match race ran some other man's horse lent and trained for that particular occasion. In these great events money was of secondary consideration. 


\section{Speaking Generally}

In the names of the horses were reflected the prominent men and important events of that and past periods. Napoleon had more namesakes than anybody. Picton, also, kept Waterloo in mind and Kosciusko divided public attention between his victories and the fate of Poland. La Fitte found some treasures for his owner but caused much to be buried. Balie Peyton's Great Western marked the beginning of a new era in trans-Atlantic commerce. In Expunge we have a reflex of a long contest in the United States Senate. Janette beat Flirtilla and Marion in 1824 and the nation's guest, who witnessed the race, was further honored by the changing of her name to Virginia La Fayette. The circumstances that led to the naming of John Bascombe indicate no feeling of personal antipathy between race horse breeders and camp meeting orators.

Nor was Rev. Hardy M. Cryer so opposed to the turf and the theatre that he could view with calm philosophy the death of his favorite, Ellen Tree. Constitution and States Rights had not then been retired to the back pasture. Even at this early period on the American race track, if nowhere else, Rights of Woman contested with Rights of Man for the crown, and cast dark shadows of future events. Nor was Cupid idle through all these years. "Many a fair belle" - as the saying then was among deferential writers of the old school - read her fate in a filly's name and had her own preserved from oblivion by the achievements of her namesake.

The principal organ of this extensive industry was The Spirit of the Times, a New York weekly, established Dec. $10,183 \mathrm{I}$, having eight, sometimes ten, pages of three col. umns each, 2,000 words to the column. W. T. Porter founded the paper and was its editor. The American Turf Register and Sporting Magazine was established by J. S. Skinner at Baltimore, in September, 1829, and was pub- 


\section{I6 Making the American 7 borougbbred}

lished there until purchased by The Spirit of the Times in I839. Both publications were conducted on the same general lines. A feature of The Turf Register each month was a likeness of some famous thoroughbred. Its picture of Coronation, in the November number, I841, was, the Editor said, "the first perfect specimen of electrotype engraving ever published in this country." It suspended publication in 1844 .

The first American stud book was compiled by Patrick Nisbett Edgar, of North Carolina, and printed in 1833. Of necessity it was incomplete and contained many errors. Before I833, and for a long time thereafter, certificates made by breeders as to the foaling and parentage of horses accompanied them through each successive ownership, together with such amendments as occasion demanded. The Turf Register opened its columns to horse owners throughout the Union and printed from first hands every pedigree that it could obtain of every thoroughbred horse of any consequence. Pedigrees thus presented were exposed to the scrutiny of those who had personal knowledge that enabled them to correct errors. By continuing this practice throughout its existence this magazine laid up priceless records in regard to American horses of that and preceeding periods and became the principal source of information for all compilers of stud books since that time.

The frrst three pages of The Spirit were usually devoted to New York theatricals, the English turf and literary miscellanies relating to hunting, fishing and the chase; and extracts from the choicest popular literature of the day - such as "Pickwick Papers," "Handy Andy," etc. The rest of the paper was given up to recording current events of interest to the breeding and race-loving world and to advertisements now valuable for their information about horses and horsemen. 


\section{Speaking Generally}

The Spirit kept special representatives in the South at all times to look after the most important racing events and the business interests of the paper. Local correspondents responded to this generous policy and helped the cause along by sending notices of events to come and accounts of races, meetings, sales, and the movements and plans of breeders. Thoroughbred cattle, sheep, hogs, colt shows and other stock shows, county fairs and agricultural societies in Tennessee and other Southern States, all received their just share of space in this New York paper. Horsemen discussed the theories and principles of breeding, the value of certain crosses, native and imported, and the possible disappearance of the game 4miler, and the best way to prevent it.

In this way The Spirit became the medium of communication - the connecting link - between the breeding interests of the entire Union. Tennessee was on the map in those days of progressive New York journalism and The Spirit wrote the names and character of Southern breeders high in the ranks of public spirited Americans. To turn the pages of this old paper is to live in another world, far distant from this, and form intimate friendships with the chief actors of a great drama, whose names, once household words in many states, are now unknown where their ashes lie buried. To call them back to earth and let them go through their parts again is to challenge the admiration of posterity for their services to the public, and secure for them an honored place in the history of their country. 


\section{Chapter II}

\section{ENGLISH ARISTOCRATS}

THE pedigrees of all thoroughbred horses of English stock now in the United States, or that have ever been here, whether native or imported, invariably trace to some of the horses named in this chapter.

In this chapter and the next, in mentioning horses in descending lines from the main stems, names are confined as much as possible to offspring whose blood reached Tennessee stock.

The relevancy of the facts set forth in the second and third chapters, to the main subject in hand, will be apparent when the reader passes to the remaining pages.

The English race horse was originally bred from the Arabian, Barbary, and Turkish stocks and contained in his veins nearly an equal admixture of the blood of each. From the Arabian blood was acquired speed, from the Barb strength and stride, and from the Turk length and height. With stock from this cross established in England's more suitable climate it was soon found that it was safest to rely on it rather than upon continued oriental importations. So the English race horse came to be an established type entirely different from any of his oriental progenitors.

In laying the foundation for this new type of horse the blood of many Barbs, Turks and Arabians was called into service. 
Curwen's Bay Barb was a present from Muley Ishmael, King of Morocco, to Louis XIV and was purchased by Mr. Curwen, together with the Thoulouse Barb, from two sons of Louis. Curwen's Bay Barb was the sire of many fine racers, among them being a mare that produced (Croft's) Partner and Soreheels and the dam of Crab. Crab himself was by the Alcock Arabian and was the sire of many "eminent" horses.

The Belgrade Turk was taken from the Bashaw of Belgrade, Turkey, at the siege of that place. The Prince of Lorraine's minister at the Court of London sold him to Sir M. Wyvills.

The Straddling, or Lister, Turk was brought into England by the Duke of Berwick after he had been at the siege of Buda, in the reign of James II. He was the sire of Snake, so named from a snake-bite; SquirreI (own brother to the sire of the grandam of O'Kelly's Eclipse) and of the noted mare that bred Squirt and other famous horses.

Other celebrated Turks that left their impress in the English blood were D'Arcy's Yellow Turk, The Alcaster Turk, The Helmsly Turk, The Marshall, or Selaby, Turk, The Strickland Turk and The HoIderness Turk.

The D'Arcy Yellow Turk was the sire of Spanker, Brimmer and the g. g. grandam of Cartouch. Place's White Turk was sire of the g. grandam of Cartouch. Place, the owner of the White Turk, was stud groom to Oliver Cromwell.

\section{Three Cornerstones}

Of the large number of the earliest Arabian, Barb and Turkish importations the English discovered the curious physical fact that very few were good foal getters. The Darley Arabian and the Godolphin Arabian were two 
notable exceptions. There were other good Arabians among them being the Leedes Arabian and the Oglethorpe Arabian, - the latter so called for his owner, the colonizer of Georgia. ${ }^{1}$ But the Darley and the Godolphin Arabians were the most famous, and ever since their day the best English horses have been either imbued with their blood or derived entirely from it. The descendants of these Arabians have rendered the English courser superior to all others, not only in the race, where, indeed, he has long excelled, but as a breeding stock. These two Arabians and the Byerly Turk are generally known among horsemen as the three great cornerstones of the English thoroughbred structure.

\section{Byerly Turk and Family}

The Byerly Turk was the most famous of all the Turks. He was used by Captain Byerly as a charger, in Ireland, in King William's wars, I689; his pedigree unknown. He sired several noted horses, among them being Basto, dam Bay Peg by Leedes' Arabian; and Jigg, "a middling horse," dam by Spanker.

\section{Darley Arabian and Family}

The Darley Arabian was a blaze face bay, about is hands high, with both hind feet and one fore foot white. He was imported into England in 1703, when four years old, by a man named Darley, a member of "a Yorkshire sporting family" who was a mercantile agent in the Levant.

The Darley Arabian got Flying Childers, Bartlett's Childers (both bred by Leonard Childers, near Doncaster)

1 This Arabian was the sire of the celebrated Makeless. The Leedes Arabian was the grandsire of Fox and others. 


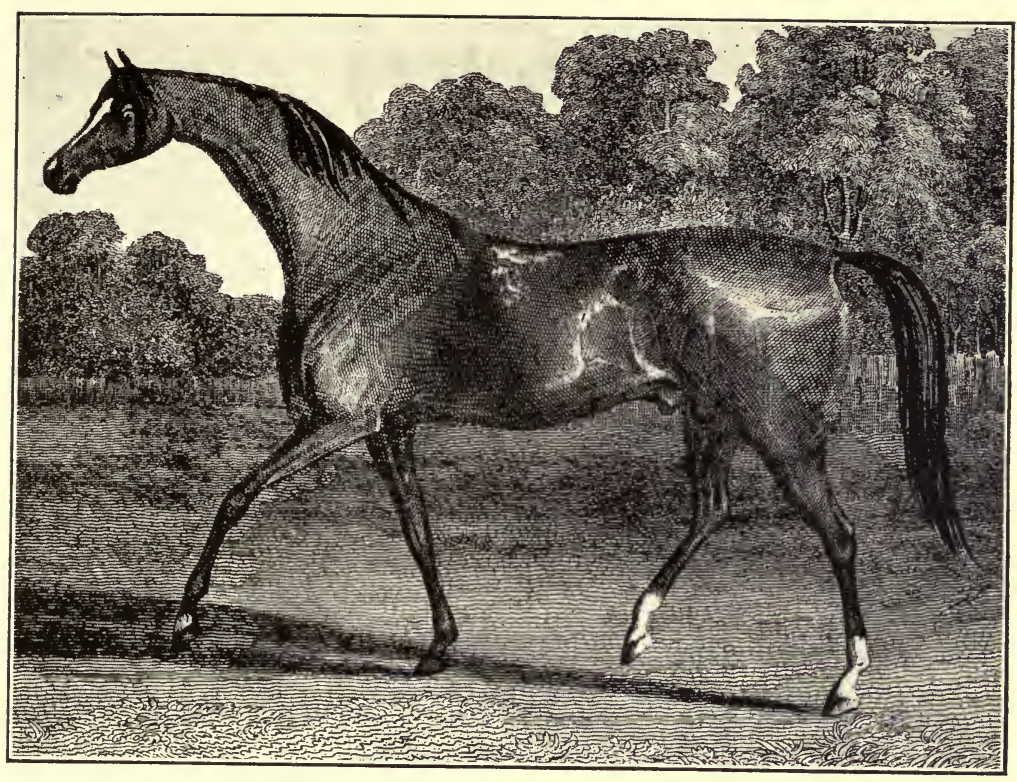

The Darley Arabian

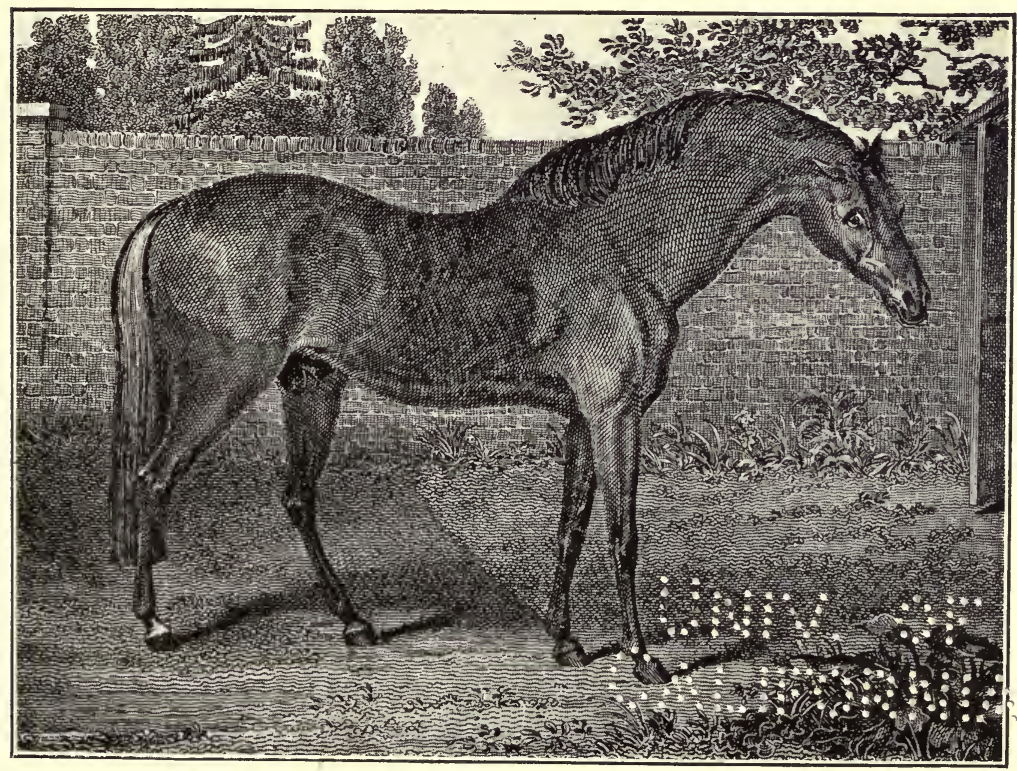

The Godolphin Arabian 
a

19 
and numerous others from whom sprang the largest and speediest race horses ever known. Bartlett's Childers was never trained. Flying Childers and O'Kelly's Eclipse, the latter a great-great-grandson of the Darley Arabian, were the swiftest horses that have ever been in the world; and Sampson, descended from the Darely Arabian, through Childers and Blaze, was the strongest race horse the world has produced.

Flying Childers was a bay with a blaze face and four white feet and is said to have been about fifteen hands high. He was foaled in 1715; his dam, Betty Leedes by Careless; - sister to Leedes by Leedes Arabian;- by Spanker; - Barb mare that was Spankers dam. Spanker was most all Barb.

In 1721 , when six years old and carrying 128 pounds, Flying Childers ran the Round Course at Newmarket, 3 miles, 3 quarters and 93 yards in 6:48-equivalent to 4 miles in 7:09. In the same year, same weight, he ran the Beacon Course, 4 miles, I furlong and 138 yards in $7: 30$ - equivalent to 4 miles in $7: 08$. This, according to a Newmarket chronicle; its accuracy is, however, questioned by many doubting Thomases.

The Editor of The Turf Register wrote that Flying Childers, when six years old, at York, ran 4 miles in $6: 48$, carrying I 28 pounds; and over another course of 4 miles, lacking 760 yards, he ran in 6:40. In the $6: 48$ race "he must have run at the rate of $5 \mathrm{I}$ feet 9 inches per second and at the exact rate of a mile in $\mathrm{I}: 42$." He gave the famous horse, Fox, 12 Ibs. over the course and beat him one quarter of a mile in a trial. Childers' owner, the Duke of Devonshire, refused an offer for him of the horse's weight in crowns and half crowns. Childers covered but few mares, except the Duke of Devonshire's. He sired, among others: 
SECOND, dam by Basto.

Blaze, dam by Grey Grantham by the Brownlow Turk.

SNiP, dam by Basto. Snip got Snap, whose dam was by Fox of Barb as well as Arabian descent.

SPANking Roger, grandam by Spanker.

Roundhead, dam Roxana by the Bald Galloway, a son of the St. Victor Barb.

\section{Godolphin Arabian and Family}

The Godolphin Arabian was a brown bay, is hands high, with no white except on one heel. He was not a beauty. He was imported into England by a man named Coke and it was strongly suspected that he had been stolen, as no information would be given as to his pedigree or the country from which he had come - only the one fact that he had been foaled in 1724. Coke gave the horse to Williams, proprietor of the St. James Coffee House, and Williams gave him to the Earl of Godolphin by whom he was kept as a teazer to Hobgoblin in 1730 and I73I. Hobgoblin, on one occasion, refusing to cover Roxana, the Arabian was called into service, the produce being Lath, a "very elegant and beautiful horse," the "best racer since Flying Childers"; but an indifferent stallion. Until his death in 1753 the Godolphin served in the Earl's stud and got a yearly succession of prodigies, among them being, besides Lath:

BLANK, dam by Bartlett's Childers.

CADE and Dismal, both out of Roxana. Cade was an indifferent racer but a fine stallion.

Cripple, gray, dam by Cade; g. dam by Childers.

Dormouse, dam by (Croft's) Partner.

JANUS, dam, the dam of Blank.

Matchless, dam by Soreheels, a son of Basto. Matchless was imported into South Carolina.

Regulus, dam Grey Robinson by the Bald Galloway. Regulus won seven King's plates when six years old and was never beat. 
$\mathrm{He}$ is generally referred to as the best son of the Godolphin. Also Babraham, Dimple and Gower Stallion.

Lath, Babraham, DismaI and Dormouse won all their races.

The Godolphin was buried with fitting ceremonies and cakes and ale were given at his funeral. Many writers have contended that he was a Barb.

\section{Live Lines of Descent}

From these three cornerstones of the English thoroughbred structure - The Byerly Turk, the Darley Arabian and the Godolphin Arabian - the "live lines" of descent were through King Herod, Matchem and Eclipse.

Repeating somewhat, to make clear the lines:

The Byerly Turk got Jigg out of a Spanker mare; Jigg got (Crofts) Partner out of a Curwen Barb mare; Partner got Tartar out of a Fox mare; Tartar got Herod. The Godolphin Arabian got Cade out of a Bald Galloway mare; Cade got Matchem out of a Partner mare.

The Darley Arabian got Bartlett's Childers out of a Careless mare; Bartlett's Childers got Squirt out of a Snake mare; Squirt got Marske out of a Blacklegs mare; Marske got Eclipse.

\section{(I) The Herod Line}

King Herod was foaled in 1758 , the property of William, Duke of Cumberland. Cypron, his dam, was by Blaze. Herod did not come on the Turf until he was five years old, ran only at Newmarket, Ascot Heath and York and invariably ran 4-mile heats; his forte was bottom and strength which enabled him to carry weight. He ran fourteen races and won ten. Out of five races for a thousand guineas each, ${ }^{1}$ he won three. Between 1771 and 1789 ,

1 A guinea was about $\$ 5$. 
497 of his sons and daughters won $£ 201,505$, several cups and 43 hogsheads of claret. Three of his get won the Oaks. During the last six years of his life he stood at 25 guineas and ro shillings. He died at Newmarket, May 12, I 780.

Florizel, foaled i768, was by Herod, dam by Cygnet, a son of the Godolphin Arabian. Cygnet's dam was by $\mathrm{Crab}$; - by Childers. Florizel was in the celebrated class. He won 16 of 23 races run and got two winners of the Doncaster St. Leger and one winner of the Derby.

WoODPECKER, by Herod, was foaled 1773 and was winner of 28 out of 35 races. His dam was by Cade. Woodpecker got Buzzard (winner of 28 races), who sired Selim, the sire of Sultan. Woodpecker sired one winner of the Oaks. He sired, in all, 176 winners of prizes worth $£_{70,189}$, besides the Whip and two cups.

Highflyer, King Herod's most celebrated son, was foaled in 1774, the property of Sir Charles Bunbury and by him sold, when a yearling, to Lord Bolingbroke. Highflyer's dam was Rachel by Blank, grandam by Regulus; - by Soreheels; - by Makeless, out of a D'Arcy Royal mare. ${ }^{1}$ Highflyer won fourteen races, was never beat, never paid forfeit; nor did he ever run after he was frve years old; yet his winnings and forfeits received amounted to 8,920 guineas. He stood one season as high as 50 guineas. He was the sire of 469 winning horses from 1783 to 1801 . Three of his get won the Derby and one the Oaks.

1 The frequent recurrence of the expression "Royal mare" in pedigrees relates to one of the Barb or Arabian mares (or their produce) purchased for King Charles II by his Master of Horse, who was sent to the Levant in 1670 to select a lot of the best stallions and mares for Hampton Court stud. 
Sir Peter Teazle, by Highflyer, was the most celebrated horse of his time and counted by some writers the best stallion that ever stood in England. Sir Peter's dam, Papillon, was by Snap, grandam by Regulus.

Snap was one of the best race horses that ever covered in England and founded a strain almost equal to that of Matchem. He was of great beauty in form and proportions, strong, vigorous, and muscular and was not surpassed in any respect by any horse of his day. The mares got by him produced more good race horses than the mares of any other strain in England. Twenty-one of them produced celebrated horses.

Sir Peter was foaled in 1784 , the property of the Earl of Derby. He won seventeen races; among them the Derby, in 1787; his losses not stated. He broke down at four years old, went into the stud and sired 296 winners of a far greater number of prizes between 1794 and 1808 . Four of Sir Peter's get won the Derby, two won the Oaks and four the St. Leger. He died Aug. ro, i8 I I.

For fifty years the descendants of Highflyer and Sir Peter Teazle were the best horses in England.

Rockingham, another of Highflyer's most famous sons, foaled $\mathrm{I} 78 \mathrm{I}$, out of Purity by Matchem, was winner of 32 out of 35 races.

\section{(2) The Matchem Line}

Matchem, foaled in I748, was out of a mare by (Croft's) Partner. Matchem won ten races and lost two. According to the same diary that records the achievements of Flying Childers, Matchem, in I755, carrying I I9 pounds, ran the Beacon Course at Newmarket in 7:20, ten seconds short of Flying Childers' time and equal to 4 miles in $6: 58$.

On being retired to the stud Matchem attracted great attention. The continued successes of his get caused his 


\section{Making the American Thoroughbred}

owner to gradually increase the fee for his service until he stood at 50 guineas, the number of mares being limited to twenty-frve, besides those of his owner, Mr. Fenwick of Northumberland. From 1764-1786, inclusive, I74 of Matchem's get won $\$ 670,870$ in specie, independent of valuable cups and subscriptions. As a stallion he profited his owner $\$ 75,480$. John Randolph wrote of Matchem: "He may be truly said to have earned more money than any other horse in the world. He was the greatest stallion ever known. He died February 2I, 178I." He got one winner of the Oaks and one winner of the St. Leger. His son most distinguished as a sire was Conductor, sire of both Imperator and Trumpator.

\section{(3) The Eclipse Line}

O'Kelly's Eclipse was out of Spiletta (by Regulus) out of Mother Western by a son of Snake full brother to Williams' Squirrel. Mother Western's dam was by Old Montagu; her grandam by Hautboy (by D'Arcy's White Turk), out of a daughter of Brimmer. Thus Eclipse inherited the blood of the two most distinguished Arabians.

He was foaled, the property of the Duke of Cumberland, during the great Eclipse of 1764. At the sale of the Duke's stud a man named Wildman, "a sporting sheepsalesman," purchased Eclipse, then a colt, for 75 guineas. Just after his victorious maiden race of 4 -mile heats, on May 3, 1769, Col. O'Kelly purchased one-half interest in him for 650 guineas and, after his eleventh race, in 1769 or I770, purchased the other half for I,000 guineas. Henceforth he was known as O'Kelly's Eclipse. He won eleven King's plates, ten of which weighed I68 pounds each.

Carrying 168 pounds, 42 more than the standard of 
Iater years, Eclipse ran 4 miles at York, in 8 minutes. According to the accepted calculations of experienced turfmen that 7 pounds extra makes a difference of a distance of 240 yards in a 4-mile heat, Eclipse moved along at a swifter gait than Flying Childers. ${ }^{1}$

Eclipse "was never beat, never had a whip flourished over him, never felt the tickling of a spur, nor was he ever for a moment distressed by the speed or rate of a competitor - out footing, out striding and out lasting every horse which started against him."

O'Kelly cleared $\$ 125,000$ by him - winning I 8 prizes. He withdrew Eclipse from the turf because no horse having a chance to win against him, the odds on him varied from 20 to IOo to $\mathrm{I}$.

Eclipse began his career as a stallion at 50 guineas a mare; reduced the next year to half that sum. In 23 years 344 horses got by him won for their owners $\$ 790,000$.

When requested to name a price for Eclipse, O'Kelly placed it at $£ 25,000$ down, in addition to an annuity of $£_{500}$ on his own life and the privilege of sending to him annually six mares. ${ }^{2}$

Marske who had been standing for half a guinea and who was sold for twenty guineas, - after siring Eclipse

${ }^{1}$ In 4 I 4 -mile heat races of 1838 , over the most popular courses in the United States, where the purse or prize was $\$ 1,000$ or more, the average winning time was $8: 12 \frac{1}{1}$; usual weights: 4 -year-olds I 00; 5-years I 10; 6-years I 18; aged I24. How far these and better horses of their day and of.later times would have been left behind by Flying Childers or Eclipse is a question referred to those who like to make figures.

${ }^{2}$ O'Kelly seems not to have been the favored son of mere luck. When Eclipse was about starting in the second heat of his first race O'Kelly placed him first and the others nowhere; and it was so. $\mathrm{He}$ bought an old hack mare by Tartar (of the Herod line) when she was past 20 years and cleared $£_{30,000}$ by her ten produce, all by Eclipse; among them being Mercury and Volunteer. 
was sold for one thousand guineas and covered at one hundred guineas.

Eclipse died February 27, I789. An exact measurement of every part of his body was made and put on record. His height at the withers was 66 inches - about $16 \frac{1}{2}$ hands; at the rump he was 67 inches. One of his hoofs was superbly set in gold, as a goblet; and nearly half a century later was presented by the King of England to the English Jockey Club. The tassel of "the Whip" was also said to have been taken from the tail of this renowned champion of the English Turf.

Eclipse got three winners of the Derby and one winner of the Oaks.

Among his get, besides Mercury and Volunteer, were:

Dungannon, dam by Herod, g. dam by Blank. Dungannon won 27 out of 30 races.

Hall's Eclipse (imported into Virginia), dam by Regulus.

King Fergus, dam by Black-and-All-Black; g. dam by Tartar.

Obscurity, imported into Virginia, in 1784 , dam by Careless (winner of ten King's plates), out of Cullen Arabian mare. This Careless was by Regulus.

Pegasus, dam by Bosphorous by Babraham. Bosphorous won seven King's plates.

Saltram, dam Virago by Snap, g. dam by Regulus. Foaled 1780. Won the Derby in 1783 . Imported into Virginia in 1800.

Also, Don Quixote, imported into Virginia; Janus, and Pot8os; Scota, dam by Herod, and Vertumnus, dam by Sweeper, g. dam by Tartar. Sweeper was by Sloe, son of Crab.

\section{Value of Crosses}

During the lifetime of Sir Peter Teazle a book was printed anonymously, setting forth the main frgures in the live lines of descent as here given. In the Herod blood, said the author of that volume, were united a strong constitution, celerity and lastingness - qualities 


\section{English Aristocrats}

"perpetuated" notably by Highflyer and his son Sir Peter Teazle. Their get, said this book, "inherit all the rare perfections that distinguish this noble race of blood. Highflyer mares are held in high estimation; Sir Peter mares cross well with the Eclipse class of blood. Woodpecker mares have also produced good runners. To the Herod blood we must apply whenever we want bottom or lastingness. The descendants of Matchem and Eclipse cross better with those of Herod than with each other."

As instances of the value of the Eclipse-Herod admixture he cites Beningbrough and Gohanna, by sons of Eclipse, out of Herod mares. All subsequent authorities take the same view; the early and continual beneficial results of these crosses has been the breeders' lode-star in England and America to the present time. In the horses mentioned in this volume the Herod-Eclipse cross has been the most frequent. ${ }^{1}$

1 For additional information about earnings of horses mentioned in this chapter see Addenda $\mathbf{B}$ at end of volume. 


\section{Chapter III}

\section{FIRST FAMILIES OF VIRGINIA}

THE greater number of thoroughbreds in the entire South and probably in the United States, in 1883, traced to some of the Virginia horses named in this chapter. This statement is made after a careful study of the pedigrees of the 88 principal stallions in service in the United States in 1883 , and the pedigrees selected, at random, of I39 thoroughbreds, bred or owned in Tennessee and Kentucky between 1888 and 1896 , the full tide period of post-bellum activities in the thoroughbred industry in the United States, especially in Tennessee and Kentucky.

Jolly Roger, known in England as Roger of the Vale, was the first horse that gave distinction to Virginia stock. He was foaled in I74I and was got by Roundhead, dam by Croft's Partner; - by Woodcock; - by Croft's Bay Barb; - by Makeless; - by Brimmer, etc. He was imported into Virginia and commenced his career in the stud about 1748 . He got many fine stallions and brood mares and his blood became a favorite cross in Virginia.

JANUS, a chestnut and, from his shoulders back, the most perfect horse ever seen in Virginia, was foaled in England in 1746 . His sire was Janus (by the Godolphin) dam by Fox; g. dam by the Bald Galloway. Janus was imported by Mordecia Booth of Gloucester County in 1752. In the third and fourth generations his descendants exhibited the same compactness of form, strength 


\section{First Families of Virginia}

and power that characterized their progenitor. The Janus stock exceeded all others in the United States for speed, durability and uniformity of shape and were noted as the producers of more good saddle horses than any other stock.

Celer, son of Janus, foaled in 1774, the property of Mr. Mead, of Virginia, propagated a stock equal in every quality to that of his sire. Celer's dam was a descendant of the Godolphin Arabian and the Cullen Arabian. He died in 1802 , aged 28 years.

Morton's Traveller, a bay, was foaled in Yorkshire, England, about 1748. His sire was (Croft's) Partner; his dam by Bloody Buttock's Greyhound, an Arabian. He had also the blood of Makeless, Brimmer, Place's White Turk and the Layton Barb mare. In 1754 Morton's Traveller was in the stud at Richmond Court House, Virginia. Many of his get became celebrated.

PARTNER, foaled in 1775, was the most distinguished son of Morton's Traveller, both as a racer and as a stallion. Partner got Rockingham out of Gen. Thomas Nelson's imp Blossom by Sloe (son of Crab), dam by Regulus; Fitz-Partner, out of the dam of Celer, and -

Mark Anthony, who was foaled about 1763. Mark Anthony's dam was Septima, by Othello, alias Black-andall-Black, and was descended from Spark who was presented by Frederick, Prince of Wales, to Lord Baltimore, who gave him to Govenor Ogle of Maryland. Mark Anthony was remarkable for his beauty, speed and bottom and propagated a stock held in highest esteem for their various valuable qualities as turf, harness and saddle horses. Mark Anthony had a habit of standing erect on his hind feet at the starting post and "screaming" until the other horses started. He also habitually passed them; in one race he distanced all seven of his competitors. 
On other occasions he frequently rose on his hind feet and walked twenty or thirty yards.

Fearnought, prior to the day of Medley, was the most famous of all the stallions in Virginia. He was foaled in 1755, the property of William Warren of England; his sire was Regulus, his dam Silvertail who had the blood of Darley's Arabian, Gresley's Arabian, the Helmsly Turk and a Royal Barb mare.

Fearnought was imported by Col. John Baylor, of Virginia, and first stood as a stallion in 1765 . He was a bright bay, is hands one inch high. AII his descendants ran well and his sons and grandsons were noted for the excellence of their get. He died in $\mathbf{1 7 7 6}$. Of his numerous offspring were: Apollo, out of an imported Cullen Arabian mare; Dandridge's Fearnought; Harris' Eclipse, out of Baylor's imported Shakespeare mare; King Herod, out of an Othello; Matchless, out of a Sober John; Regulus, out of imp Jenny Dismal by Dismal; Whynot, out of an Othello, and -

Symmes' Wildair, out of a Jolly Roger, and who proved to be best son of old Fearnought.

Among Wildair's get were Commutation, Highflyer and Chanticleer; the last named the sire of John Randolph's Gracchus.

Other distinguished stallions of Colonial Virginia were: imp Justice, imp Vampire and imp Merry Tom, all by Regulus; imp Juniper by Babraham; imp Ranter by Dimple, dam by Crab; imp Aristotle by the Cullen Arabian; Sterling by the Belsize Arabian and Selim by Othello. None of these Virginia owned horses were more than $15^{\frac{1}{2}}$ hands in height. In their day Virginia was famed for her saddle horses. ${ }^{1}$

1 To prove that the important thing in a horse was to have a well organized frame, with plenty of sinew, rather than sheer height and 


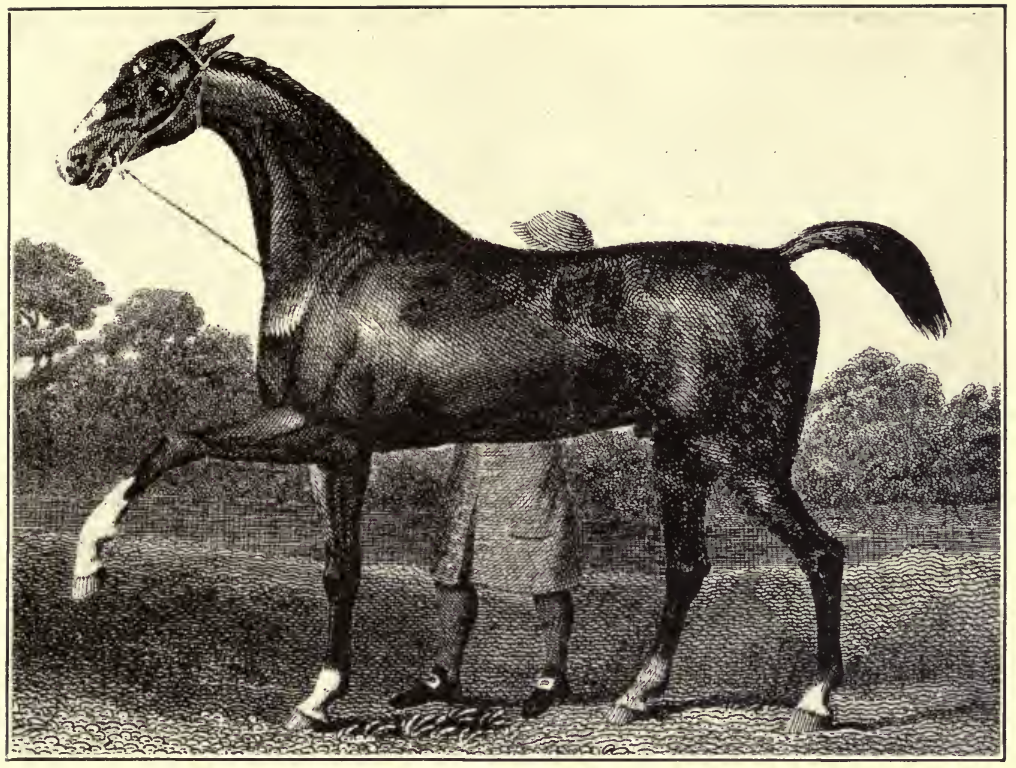

Flying Childers

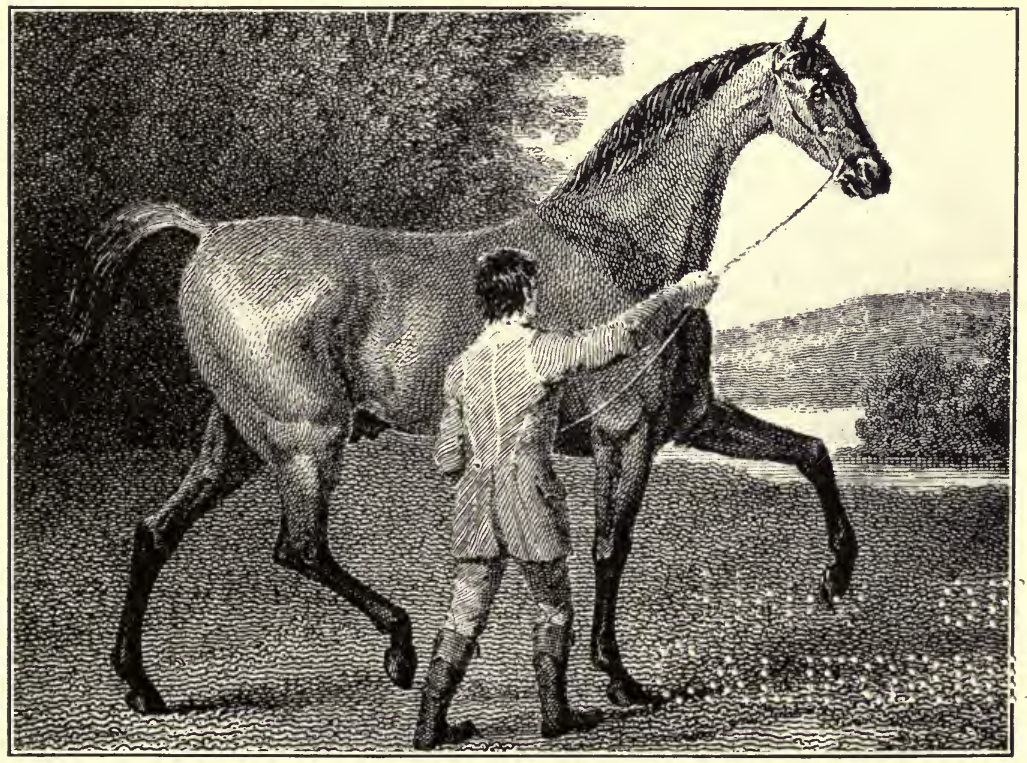

King Herod 
a

and 


\section{Famous Imported Mares}

Among the famous mares imported into Virginia before the Revolution - besides Blossom and Jenny Dismal were:

Mary Gray, by Roundhead, imported I746; owned by Carter Braxton. She produced seven filly foals by Jolly Roger. Through her daughters she gave the Flying Childers' blood to innumerable descendants and became the most celebrated brood mare in America.

Kitty Fisher, by Cade. Imported by Carter Braxton.

Jenny Cameron, by a son of old Fox, and her daughter, Blazella, by Blaze.

Besides mares mentioned elsewhere that were imported into Virginia after the Revolution, were these imported by Col. John Tayloe, of Mt. Airy:

Anvilina, foaled 1794, by Anvil, son of Herod, out of O'Kelly's famous Augusta, by Eclipse. Presented by

bulkiness, The Turf Register in 1830-31 reprinted from The American Farmer a table showing the height of 134 of the most celebrated horses in England prior to the Revolution. Only one of the I34 was as high as 16 hands. Of the remaining 133 only one was as high as 15.3, five 15.2, twelve is hands. Twenty-nine were under 14 hands. Among others: Babraham was 16 hands, Blaze 15, Cade

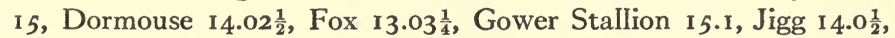

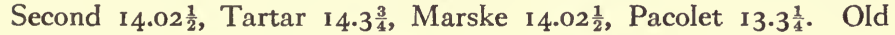
Cartouch, by the Bald Galloway, was not over 14 hands, "yet no horse in the kingdom was able to run with him at any weights from eight to twelve stone." Neither Flying Childers nor Eclipse conformed to the standards for symmetry but "the mechanism of Eclipse's frame was almost perfect. The velocity of his gallop could only result from the harmonious combination in the organs of progression." In Flying Childers "the strength of Ioin and general compactness of form, upwards, doubtless supported his extraordinary reach and enabled him to make those wonderful springs recorded of him." 


\section{Making the American Thorougbbred}

Col. O'Kelly to Col. Tayloe and sold to Col. Alston of South Carolina.

Also, Peggy, foaled 1788, by Trumpator, dam by Herod; and her daughter Brittannia by Pegasus; Flirtilla by Vertumnus, dam by Conductor; and Augusta by Saltram.

By Col. John Hoomes: Volante by Volunteer, and Favorite by Volunteer, dam by Matchem.

Among other mares imported into Virginia, before and soon after the Revolution, were one each by the Cullen Arabian, Bartlett's Childers, the Belgrade Turk, Tartar, Volunteer, O'Kelly's Eclipse and Highflyer. ${ }^{1}$

To a more or less degree the blood of all these mares eventually reached Tennessee stock.

\section{Post Revolutionary Sires}

Among stallions imported into Virginia after the Revolution were Pantaloon by Herod; Robin Redbreast, two Sir Peter Teazles, and Starling, all by Sir Peter Teazle; Seagull by Woodpecker; Spadille, St. George and St. Paul, all by Highflyer. ${ }^{2}$

The most famous sires of the post Revolutionary period were those sketched below.

The Lindsay Arabian whose name appears frequently in Tennessee pedigrees was presented by the Emperor of Morocco to the Captain of an English vessel who, en

I Among importations of mares into other states were: three by Sir Peter Teazle, one by the Cullen Arabian and one by Pot8os into South Carolina and Nancy Bywell, by Matchem, into Maryland. Still other importations, states not given, were: a mare by Cripple; one by Sir Peter Teazle, and one by Babraham.

2 Among importations of stallions into other states before and after the Revolution were Snap and Snipe by Snap; Prince by Herod; Star by Highflyer; and another Sir Peter Teazle by Sir Peter Teazle - all into South Carolina, from which state many horses went to Tennessee. 
route to England, landed in the West Indies. Turned out for exercise the horse fell from a high elevation and broke three of his legs. The owner then presented the horse to a sea captain who lived in Connecticut, to which State the horse was taken in 1766 . In 1777 or 1778 Gen. H. Lee, of the American cavalry, and his officers, were attracted by the superior form and appearance of some eastern horses employed in the cavalry. Upon inquiry the officers learned the story of the sire, as stated above. Gen. Lee then sent Capt. Lindsay to make more minute investigations with instructions to buy the horse if he answered the description given. The horse was purchased and sent to Virginia. He was white and of the most perfect form and symmetry, of lofty carriage and commanding appearance and proved a great success in the stud. Among his get was Gen. George Washingon's Magnolia (dam by imp Othello) who stood at Mt. Vernon in 1785 at $£ 5 .{ }^{1}$

SHARK, imp br. foaled I77I; by Marske, dam by Snap; - by Marlborough, full brother to Babraham and imp Selima; - natural Barb mare. Shark ran 29 races in England and won 19. Among his trophies were a gold cup, eleven hogsheads of claret and 20,000 guineas in plates, matches, forfeits, etc. "When no horse could be found in England to start against him," it was announced that he would be shipped to America, whereupon ro,ooo guineas were publicly offered for him to keep him in England. He was imported into Virginia by Col. John Tayloe and

1 About 1790 at a Jockey Club meeting at Alexandria, Virginia, at which Washington acted as a judge in some of the races, Magnolia ran a race and lost. Thomas Jefferson was more fortunate; at this same meeting his horse called the Roan colt is said to have won. Washington Iater sold Magnolia to Gen. H. Lee for $\$ 1,500$. Gen. Lee sent him to South Carolina and sold him for a handsome profit. 


\section{Making the American Thorougbbred}

died there about 1796, aged 25. Among his distinguished get were the grandam of Virginian, and the g. g. grandam of Sir Charles.

MEdLey was a son of the "little gray horse Gimcrack" who was foaled in 1760. Gimcrack's sire was Cripple and his grandam (some writers say dam) was by (Croft's) Partner. Gimcrack was one of the severest running and hardest bottomed horses that ever ran in England. He kept it up till he was I I years old. Though I4 hands and one quarter of an inch he was able to carry great weight, frequently giving odds as high as $28 \mathrm{Ibs}$. Both in England and in France he "swept the deck" of his famous competitors. Four and five-mile races were his chief delight. Such was his celebrity that his last owner left him for a long time at Tattersalls for close inspection by his enthusiastic admirers.

Medley, foaled 1776, was imported into Virginia in I785 by Malcolm Hart. Medley's dam was Arminda (full sister to Papillon) by Snap who was only I4 hands and one-half inch high. From Snap, Medley got his beauty, symmetry and strength. The want of size in the Medley stock was no obstacle to their success on the race course. They could carry more weight than other stock and they had better bottom, better limbs and better eyes than any other stock of horses ever bred in Virginia. This fact was due to their peculiar physical formation, and the purity of their blood, Medley being one of the purest bred horses ever produced in England. He stood at Hanover Court house. Col. John Tayloe who, between I79I and I808, won II 3 out of I4I races run by his horses, said that Medley was one of the most beautiful horses he ever saw and his stock the best in Virginia. Among Medley's distinguished get were Quicksilver, Young Medley, Melzar, Gimcrack and - 


\section{First Families of Virginia}

Bellair, bred and owned by Col. John Tayloe, and Medley's most distinguished son, not only as a racer but for the purity of his blood and the success of his get as racers, stallions and brood mares. He had the blood of Fearnought, Partner, Mark Anthony and Morton's Traveller and their distinguished ancestry. His great grandam was imp Selima (fuIl sister to Babraham) imported by Col. Tasker of Maryland. She produced I3 foals. Bellair lost only one race and that, when out of condition, to Gimcrack. In i791 Col. Tayloe refused an offer of $\$ 10,000$ for Bellair. He had numerous descendants in Tennessee.

Diomed was foaled in 1777, the property of Hon. Richard Vernon, of Newmarket, by whom he was sold to Sir Charles Bunbury. He was got by Florizel, dam sister to Juno by Spectator; g. dam by Blank; - by Childers; Miss Belvoir by Gray Grantham; - by Paget's Turk; Betty Percival by Leedes' Arabian; - by Spanker. Spectator's dam was by (Croft's) Partner. Spectator was by Crab.

Diomed was $15^{\frac{3}{4}}$ hands high and was a solid chestnut without white except on the heel of his right hind foot. He came on the turf in 1780 and in his first season won seven straight races one of which was the Derby at Epsom (he was the first Derby winner) and another, a sweepstake, of 500 guineas each, at Newmarket. Summing up his career; he won ten races and received one forfeit, was beat eight times and paid one forfeit. He was placed in the stud in 1785 at 5 guineas and in 1789 was raised to Io guineas. In England he got 65 "most distinguished" sons and daughters, besides many others of lesser note. His son, Grey Diomed, was one of the most noted horses that ever ran in England; and in Russia he ran with such success that several of his stock were sent for from that empire. 


\section{Making the American Thoroughbred}

Diomed was imported into Virginia in the spring of 1789 by Messrs. Lamb and Younger who had paid 50 guineas for him. He had lost popularity in England because of the obstinacy of his get. Soon after reaching Virginia he changed hands several times, the price in one deal being 1,000 or 1,200 guineas. As the property of Col. M. Selden and Thomas Goode he stood two seasons at Goode's in Chesterfield and, it seems, was kept all his life in Virginia.

Among the most renowned of Diomed's get in this country were: Ball's Florizel, dam by imp Shark, foaled I802; Duroc, dam Amanda by Grey Diomed, I806; Madison, dam by Chanticleer; Potomac, dam by Pegasus, I8or; Stump-the-Dealer, dam by imp Shark, I8or; Virginius, dam by Chatham, grandam by Hall's imp Eclipse, I805; and Sir Archy. Also the dams of Henry, Eagle, Corporal Trim and Sir Alfred; Bolivar's grandam; and others whose names are prominent in the early history of Tennessee stock.

In I83 I a writer said that there was not a good horse in Virginia that did not have Diomed's blood, or that of one of his descendants in his veins, and in 1883 so eminent an authority as Mr. Bruce said, "there is scarcely a good horse in England today but what has some of his blood."

Diomed died in Virginia in 1807 or 1808 , leaving behind him "a name and a fame which will endure to the end of all time, and crowned with the laurels of the two great racing countries of the world, England and America." 1

BEDFORD, foaled in 1792, was got by Dungannon, dam Fairy by Highflyer, g. dam by Young Cade; - by

1 Among the eminent Virginians who appreciated Diomed's qualities was Thomas Jefferson, whose Monticello, bred by him, was by Diomed, out of a mare by Chanticleer best son of Wildair and best horse of his day. 
Crab, out of the Warlock Galloway. He was bred by Lord Grosvener and was imported into Virginia by Col. John Hoomes. He was one of the best horses ever brought from England and left a numerous and valuable offspring. His blood was valued highly by Tennessee breeders, as evidenced by the frequency of his name in Tennessee pedigrees.

\section{The Godolphin Arabian of America}

In 1779 Col. John Tayloe imported a brown mare, Castianira, by Rockingham, dam Tabitha by Trentham; g. dam (the dam of Pegasus) by Bosphorus. Together with shipping charges, Castianira cost $\$ 750$. She made no distinguished frgure on the turf and was soon withdrawn. Her second foal, by imp Diomed, was dropped in May, 1805 , as the joint property of Col. Archibald Randolph of Ben Lomond, Virginia, and Col. John Tayloe. This was Sir Archy, doubtless named for Col. Randolph. He was a blood bay with no white except on the heel of his right hind foot. He grew to be 16 hands.

Sir Archy first appeared on the turf in 1808 when, having the distemper, he was more than distanced in a sweepstake at Washington, by Bright's Phoebus by Messenger. Col. W. R. Johnson, of Petersburg, Virginia, who witnessed the race, immediately purchased Sir Archy for $\$ 1,500$ and under Johnson's management he won every race he ran.

Johnson's challenge to run him against any horse in the world not being accepted, Sir Archy began his career as a stallion in 1810, as the property of Maj. A. J. Davie of Halifax County, North Carolina, who paid $\$ 5,000$ for him. Later he came into the possession of J. D. Amis of Northampton County, North Carolina, who, in I833, was quoted as saying that Sir Archy, in the stud, had netted him $\$ 76,000$. In 1829 he stood at $\$ 100$ to insure. 


\section{0 Making the American Thorougbbred}

In a list of 80 or 90 of Sir Archy's distinguished get it does not affrrmatively appear that any one of them except Virginia Taylor was bred in a Northern state; all others - or nearly all - seem to have been produced in MaryIand, Virginia, North Carolina and South Carolina. But after winning fame on the turf they carried the dynamic force of the Archy blood into the stock of all states, and gave to their distinguished sire the well-merited title, "The Godolphin Arabian of America."

Among Sir Archy's distinguished get were: Bertrand, foaled I821; Cherokee; Corporal Trim, I825; Flirtilla, I820; Gohanna, I821; Henry, I816; Industry, I824; Isabella, I82I; Janette, alias Virginia LaFayette, 1820; John Richards, I819; Kosciusko, I812; Lady Lightfoot, I8ı2; Marion, I820; Mucklejohn, I827; Pirate, I823; Reality, I813; Sally Gee, alias Pandora, I825; Sally Hope, I822; Sea Gull, about I8I5; Sir Archy, Jr., alias "Montorio," alias "Out-of-Transport," I822; Sir Arthur; Sir Charles, 18ı6; Sir William, out-of-Transport; Sumpter, I818; Tariff, I824; Vanity, I8ı2; Virginian, I8ı3.

Records at hand do not show that any of the above named horses served as stallions in Tennessee, or that any of the mares were owned here; but all of them, more or less, had descendants in Tennessee. Of Bertrand (bred by John R. Spann of South Carolina) Wallace wrote in 1867: "he was unequalled on the turf and in the stud had no rival" and "did more to improve the stock of Kentucky and Tennessee than any horse before or since his day." A short time before his death his owner James Lindsay, of Lexington, Kentucky, refused an offer of \$35,000 for him. Of equal fame was Sir Charles, both on the turf and in the stud. Of the others in the list here given the following named were perhaps the most celebrated for their performances on the turf: Flirtilla, 
Henry, Isabella, Virginia LaFayette, John Richards, Lady Lightfoot, Reality, Sally Hope, Vanity and Virginian. Sir Archy was most noted for his ability to get stock capable of winning at all distances, and this trait he transmitted to his sons to a remarkable degree. His daughters, also, proved true to the blood of their sire in producing stock of speed and endurance. More remains to be said of Sir Archy and many of his get. Here it is not inappropriate to quote an announcement made between mourning border lines in The Turf Register of July, I833:

"Extraordinary Coincidence - Deatb of Two Distinguisbed Characters on the Same Day. - OId Sir Archy and his son Sir Charles, by whose great achievements the fame of the sire was sustained and elevated, both expired on the 7 th of June.

"Peace to their ashes! - Theirs was an enviable destiny. ...

"How few of us can boast of having so honestly acted well our parts as did these two noble animals. And well were they rewarded by the humanity of their owners, and the pleasures procured for themselves by the glory of their achievements." I

${ }^{1}$ For additional information about horses mentioned in this chapter see Addenda C. 


\section{Chapter IV}

\section{HARDY TENNESSEE PIONEERS}

THE pedigrees of practically all thoroughbreds produced in Tennessee and Kentucky, and the pedigrees of a majority of all the thoroughbreds produced in the United States, between 1883 and 1896 , trace to some of the horses named in this chapter and the next, as standing in Tennessee prior to 1845 .

As early as 1790 , according to Killebrew's "Resources of Tennessee," the following named thoroughbred stallions were brought to Sullivan County, which joins Virginia: Stately, Milton, Genus (doubtless Genius), Flag of Truce, Don Quixote, Diomed and Peter Quicksilver. The leading men in this movement were Col. John Scott, Col. William Blevins and members of the Snapp, Tipton, Greene and Rutledge families. Killebrew gives no pedigrees, hence I am unable to identify any of the horses. The records show, however, that horses of these names were of this period. The only imported horse named Diomed was the sire of Sir Archy, and he was not imported until 1799.

Though I can find no authority other than Killebrew for the statement above made, there is still indisputable evidence that the thoroughbred beat the Constitution to Tennessee; or, to state it another way - "the Constitution followed the flag" of the thoroughbred to Tennessee.

Between 1790 and 1795 the following named stallions (pedigrees given here as in advertisements) were adver- 
tised in The Knoxville Register and State Gazette to stand in East Tennessee. The words in parentheses are mine.

Brilliant (said to have been imported and by "old" Peacock); at John Gibson's near Bulls Gap; service 30 shillings and a bushel of grain.

Brimmer, by Old Clubfoot (by imp Janus) out of Doll Pearson by old Pearson; at William Cocke's; $\$ 6$.

Chatham, by old Chatham (said to have been bred by Lord Chatham) dam Venus by Olympus. Bred by Capt. Williams of Maryland. At Alexander Brown's, Jefferson County; season 20 shillings.

LABURnam, by old Laburnam, dam a full blooded Fearnought; at Hesekiah Bayles; Knox County. (Old Laburnam was by imp Lath by Shepherd's Crab. Old Laburnam's dam was by imp Jolly Roger).

Leadall, by Selo (evidently Celer) "out of a Janus and Fearnought, mare," at William Shelton's, German Creek.

Rainbow, foaled May 2, I 787, by Dandridge's Fearnought, dam by Dreadnought. Bred by Capt. Harrison, Brunswick County, Virginia. At Charles Gilliam's, Knox County.

Raven (said to have been by "imp" Raven); at Stephen Duncan's near Knoxville; $\$ 3$ and a bushel of oats; 40 shillings to insure.

Young Northumberland, by imp Northumberland, dam by imp Bulle Rock; advertised by John Adair and Robert Christian to stand season 1792 at John Adair's place near Knoxville; \$3.50. (Imp Northumberland was by Bustard - probably the one by Crab. Imp Bulle Rock, imported in $173^{\circ}$, aged twelve years, was by the Darley Arabian. There were three native bred Bulle Rocks of later periods; one of these may have been meant, though the first was possible.)

Young St. George, by imp St. George, dam "by the old Arabian who was imported and come out of the famous Rosetta." Season 1792 at James Manasco's and Lazarus Dodson's, Greene County; $\$ 2$ and a bushel of corn. (The imp St. George referred to was most likely the one foaled $177 \mathrm{I}$, by Dragon, out of a mare by Blank.)

All of the horses hereinafter named as standing in Tennessee prior to 1840 descended from the Darley Arabian, or the Godolphin Arabian or the Byerly Turk, or 
from all three; this fact will not, as a rule, be further noted in pedigrees. Most all of these horses descended, also, from Herod, or Matchem or Eclipse, or from all three. Where the blood of any one of these three horses was prominent in a pedigree, and this fact does not otherwise appear, it will be indicated by the letters $\mathrm{H}, \mathrm{M}$ or $\mathrm{E}$ as the case may be.

\section{Stallions Between i80o and i8io}

The most noted stallions known to have stood in Tennessee between 1800 and 1810 were those named below. Except in one or two cases noted the cost of service did not exceed $\$ 30$ and was always payable in cotton, pork, beef, cattle or other "country produce," as the equivalent of money.

In this decade and the next, eight grandsons of O'Kelly's Eclipse and numerous representatives of the Herod and Matchem families laid a solid foundation for the Tennessee stock.

"Grey Medley, foaled I79I; got by imp Medley; dam by True Whig; g. dam Circe by Ariel. True Whig by Regulus (son of imp Fearnought) dam imp Jenny Dismal, by Dismal; g. dam by Lord Godolphin's Whitefoot. Ran at Tappahannock, Va., and taken to Tennessee."

The above quotation from "Wallace's Stud Book" as to Grey Medley's dam and age is supported by the testimony of Dr. R. D. Barry. In The Knoxville Register and State Gazette of March 20, 1799, Dr. Barry advertised Grey Medley to stand that season "at the Brothers Cottage adjoining Knoxville, the seat of Dr. Claiborne." In that advertisement he stated that Grey Medley's dam was by True Whig - which is the main point of difference between Wallace and Skinner. Dr. Barry also 


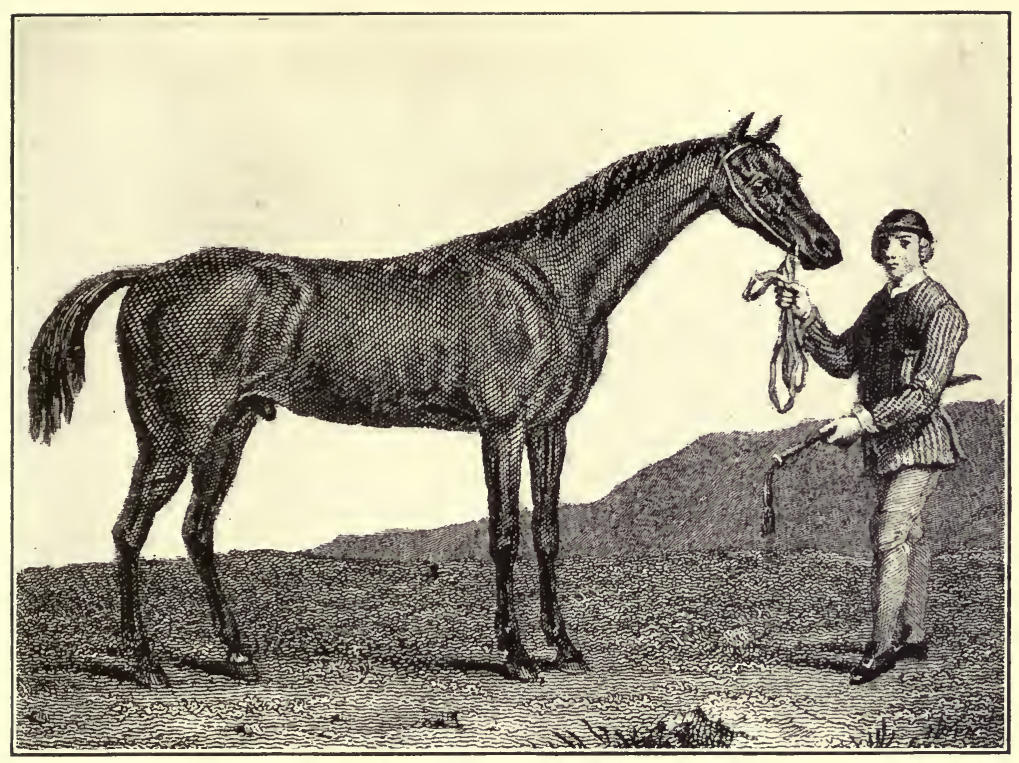

Matchem

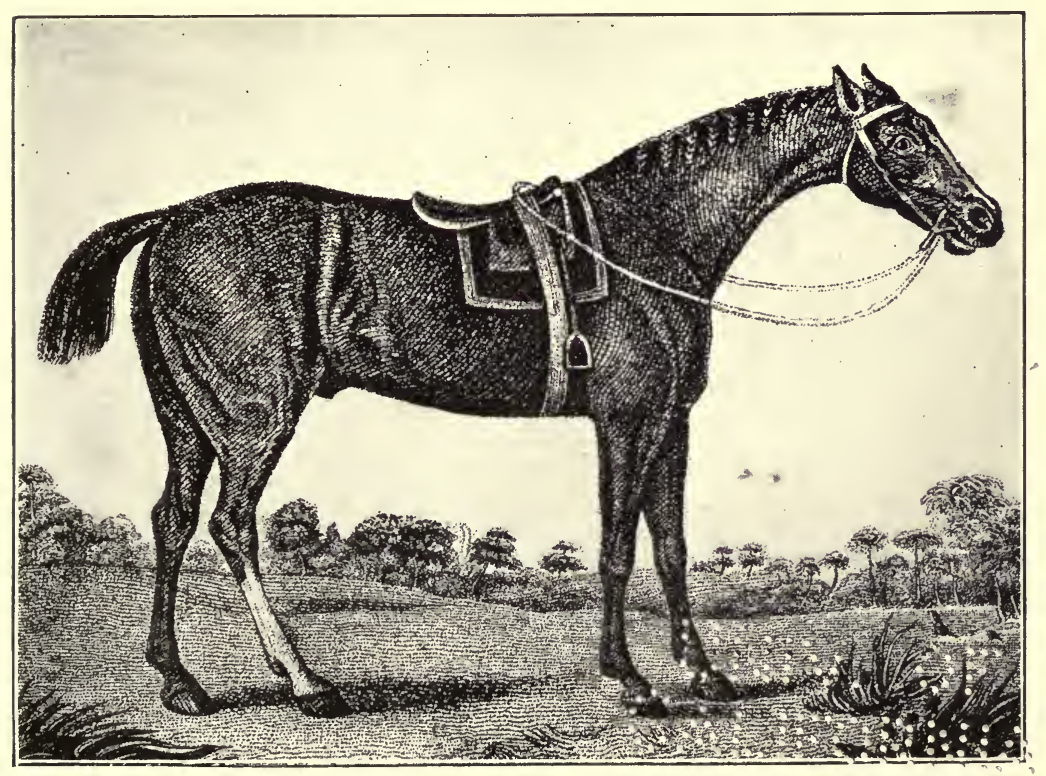

O'Kelly's Eclipse 


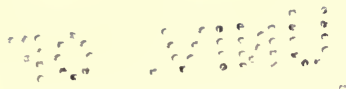

$$
\begin{aligned}
& \therefore
\end{aligned}
$$


printed a certificate signed by Lawrence Muse, Secretary and Treasurer of the Tappahannock Jockey Club, and Col. John Tayloe, of Mt. Airy, Virginia, stating that on May 13, 1795, Beckwith Butler's Grey Medley ran as a 4-year old at Tappahannock, defeating four competitors.

The season of I80o Grey Medley stood at the farm of William Donelson, ten miles from Nashville, on the Gallatin road; and for several years thereafter at the farm of Dr. Barry, in Sumner County. In The Nashville Clarion of March, 1810, he was advertised to stand at William Blackwell's, Parson's Creek, Montgomery County; \$8; \$12. He was very vicious. Bred by Gov. Williams, of North Carolina.

Tradition says that Grey Medley was the first thoroughbred stallion brought into Middle Tennessee. Quite to the contrary, yet worthy of consideration, is the statement made by Dr. Felix Robertson to Judge William Williams, in 1856, that about 1788 his father, Gen. James Robertson, brought from Maryland to Nashville "a thoroughbred - he thinks called Whynot." But it is generally believed that the thoroughbred industry of Middle Tennessee began with Grey Medley and mares already here in 1800 or brought soon thereafter. ${ }^{1}$

It is worthy of remark that Mr. W. O. Parmer's "Edenwold," the one remaining thoroughbred nursery of any importance in Tennessee, embraces part of the William Donelson estate which is said to have witnessed the beginning of the thoroughbred business in this section.

\section{Horses that Occasioned Duels}

Ploughioy, dk. b., foaled 1798; by imp Bedford, dam Miss Queenland by Gen. Daniel Morgan's celebrated

${ }^{1}$ For other evidence on question here considered see "Panton's" statement, Addenda D. 


\section{Making the American Thorougbbred}

Paul Jones; - Selima by imp Jolly Roger; - imported mare by Matchem. Paul Jones was by Specimen (son of imp Fearnought), dam Filis by Gov. James Delaney's imp Wildair (reshipped to England) by Cade. Specimen's dam (according to Erwin's advertisement) was Gen. Thomas Nelson's imp Blossom; Bruce says she was imp Jenny Dismal.

Bred by Col. John L. Alexander, of Virginia; owned in 1805-06 by Capt. Joseph Erwin (or Ervin) and advertised by Corbin Lee, manager, to stand the season of 1806, beginning April 10, at Capt. Erwin's, Nashville; service 100 weight clean, merchantable cotton; 200 weight to insure. Following is an excerpt from this advertisement, which appeared in the Impartial Review during February and March - and possibly in January - 1806.

"The prefent engagement with this horfe is such that he cannot be put to mares any fooner than the above ftated time - $\mathrm{He}$ is now engaged in a match of 3,000 dollars, half forfeit, against Gen. A. Jackfon's celebrated Truxton, to run on the $3 \mathrm{~d}$ of April. - In a few days after the race he will be ready to receive mares, and be properly attended to. This race being one of very confiderable importance, will, no doubt, excite a very numerous concourfe of fpectators, who will then, if not before, be able to decide whether or not Ploughioy merits the attention and preference of fportfmen and gentlemen breeders - Gentlemen who wifh to breed fine horfes would do well not to put their mares to horfes until after the race, as at that time it will be seen (barring accidents) whether or not he be the true bred racer."

In a match between Truxton and Ploughboy, set for Clover Bottom in the fall of 1805 , Capt. Erwin and his son-in-law, Charles Dickinson, had settled forfeit in a way satisfactory to Jackson. Statements credited to Jackson regarding the terms of settlement, which statements Erwin and his friends thought reflected upon Erwin's honor, started a bitter controversy about January I. 


\section{Hardy Tennessee Pioneers}

Dickinson's first contribution to this controversy was a letter written to Jackson on January $\mathbf{1 0}$, and delivered after Dickinson's departure for New Orleans. Dickinson's second contribution was a communication to the Impartial Review immediately after his return about May 2oth. It was this article that brought Jackson's challenge, Dickinson's death, and a wound that caused Jackson great physical suffering at frequent intervals the remainder of his life - even in his dying hours.

During Dickinson's absence the controversy raged in the columns of the Review - the impartial Review; it brought a caning to Thomas Swann from Jackson; and a dueI between McNairy and Coffee, on March Ist.

The second match between Truxton and Ploughboy may have been arranged before the controversy started - there is no evidence extant on that point. But it is more than probable that it, too, grew out of this Quixotic quarrel. And it is certain that the intense feeling between the two factions found expression at Clover Bottom on April $3 \mathrm{~d}$ and made this Truxton-Ploughboy contest the most serious ever witnessed there. That everybody was expected and that standing room would - it was thought - be at a premium, is shown by the following advertisement that appeared in the ever impartial Review, March I5, I806, and on divers dates thereafter:

\section{Clover Bottom Race}

On Thurfday the 3d of April next, will be run, the greateft and moft interefting match race ever run in the Weftern country, between Gen. Jackfon's horfe

\section{TRUXTON}

6 years old carrying I 24 Ibs. and Capt. Jofeph Erwin's horfe PLOUGHBOY

8 years old carrying 130 lbs. - These horfes run the twomile heats, for the fum of 3,000 dollars. No stud horfes can 
be admitted within the gates, but such as contend on the TURF - and all perfons are requefted not to bring their dogs to the field, as they will be shot without refpect to the owners. March rft. 1806 .

Ploughboy was not advertised in the Impartial Review after April 3, I806, nor in either of the two subsequent years. A possible reason for this may be found in the statement of Jackson quoted below.

Truxton, foaled I800; Is hands 3 inches in height. Advertised by Gen. Andrew Jackson to stand seasons of 1807 and 1808 in charge of John W. Clay "on the hill adjoining town near the College seat"; \$20 payable within the season; \$30, longer credit, in "merchantable ginned cotton." In I809 Truxton stood at Clay's at \$50. In I8I6 he stood at Will Trigg's stable, Gallatin, at \$10; $\$ 20$ to insure; all "notes payable to Maj. Gen. Andrew Jackson."

"We should be pleased to have a minute account of the performances of Truxton," wrote editor Skinner, of The Turf Register, in the December number, 1833, "but the following which we find in the tenth volume of The American Farmer is the only one we have. Every drop of his blood is to be prized wherever it is to be found."

The article then quoted is one by Gen. Andrew Jackson and is as follows:

"Truxton is a beautiful bay, full of bone and muscle; was got by the imported horse old Diomed, and came out of the thoroughbred mare Nancy Coleman, the property of Maj. John Verrell of Virginia. Truxton is, however, too well known to require minute description. His performances on the turf have surpassed those of any horse of his age that has ever been run in the western country; and, indeed, it might be said with confidence, that he is equal, if not superior, to Mr. Ball's Florizel horse, who was got by the same Diomed, and who now stands unrivalled in Virginia as a race horse.

"Truxton, by old sportsmen and judges, is admitted to be amongst 


\section{Hardy Tennessee Pioneers}

the best distance horses they ever run or had to train. His speed is certainly known to all of those who have run against him. He has, on the most unequal terms, started against the very best mile horses in Kentucky and Tennessee, and beat them with great ease; and in no one instance has ever run with any horse, when he himself was in order, but he either could or did distance him with ease. Although the four mile heats is the real and true distance for Truxton to run, he has beaten Mr. Gordon's five mile horse, Jack-of-Clubs, and Mr. Cotton's Greyhound, both aged horses, with equal weights of roo Ibs. on each, the single mile heats.

"And Iastly, to crown the much doubted speed of Truxton with his opponents, he beat, on only two sound legs, on the $3 \mathrm{~d}$ of April I806, over the Clover Bottom turf, the celebrated horse Ploughboy, who was never before beaten, and beating him without the assistance of whip or spurs. It is now no longer difficult for the numerous concourse of people who were present on that day to say 'whether or not Truxton be the true bred racer.'

"Truxton's winnings, from time to time, from the most correct information, amount to at least twenty thousand dollars, and his colts are not inferior to any on the continent.

$$
\text { "ANDREW JACKSON." }
$$

Appended to this communication was this certificate signed by Samuel Pryor:

"I do certify that I have trained the above mentioned horse Truxton, and with truth can say that I believe him in point of speed and bottom equal to any distance horse in America."

And a certificate from Maj. John Verrell of Dinwiddie County, Virginia., in which he gave the pedigree of Truxton's dam as follows:

"Nancy Coleman, was got by young Fearnought; her dam Latona, by old Partner; her grandam by the imported horse Jolly Roger; her g. grandam by the imported horse Skim, out of a Barb mare.

"Given under my hand this Ioth March 1806.

"John Verrell."

In no account of the Jackson-Dickinson duel that I have seen is mention made of this last race between Trux- 
ton and Ploughboy; yet, no matter how good a loser Dickinson was under ordinary circumstances, Truxton's victory could not have failed to intensify his feeling against Jackson at the time he wrote the article which brought Jackson's challenge.

\section{Other Rich Blooded Sires}

Baronet, imp b. foaled 1785; by Vertumnus, dam Penultima by Snap; g. dam by Cade; - by Crab; - by Flying Childers. Imported into New York with Pot8os mare, grandam of American Eclipse. As property of Walter Carr, James Martin and D. McGavock made season 1807 north of Nashville - "below the stone bridge on the road to McGavock's Ferry"; \$15, \$24. Empress, the grandam of the famous Ariel, was by Baronet. "Of all importations," says "Frank Forester," "none equalled him in elegance and finish."

Burrampooter, by imp Dare Devil, dam by Symmes' Wildair. Dare Devil by Magnet son of King Herod. At Augustine Willis', West Harpeth, 1806; at David Squier's, Franklin, I808.

Coevr de Lion, imp b., by Highflyer, out of Dido by O'Kelly's Eclipse. Foaled 1789; imported in 1800 by Col. John Hoomes of Virginia. Owned by Elisha Williams, then by his son, Judge William Williams. Stood three seasons in North Carolina, and after that in Davidson County, Tennessee, until his death in 1809. In 1807,1808 he stood at the farm of Joseph Phillips, 7 miles north of Nashville; \$25; \$30.

Crawler, foaled 1792; by Highflyer, dam Harriet by Matchem; g. dam by Regulus; - by Bartlett's Childers; Bred by the Duke of Grafton.

Doublehead, by imp Diomed, dam Polly Medley by Grey Medley; I 807 at R. C. Foster's, three miles southeast of Nashville, "on the Jefferson road"; \$20; \$25; I808 at Joseph Park's stable in Nashville; $\$ 25$. At one time owned by Gen. Andrew Jackson.

Sour Crout, imp b., foaled I786; by Highflyer, dam Jewell by Squirrel; - by Blank; - by Second. Sour Crout was sire of Mambrino's dam.

Royalist, imp red b. foaled 1790; by imp Saltram (winner of The Derby in 1783) dam by Herod, grandam by Marske. Bred by The Prince of Wales; imported into New York; 1806 at Nashville; 1807 


\section{Hardy Tennessee Pioneers}

(as property of Judge Robert Weakley, William Patton Anderson, and Joseph Coleman, first mayor of Nashville) stood in charge of J. W. Clay "on the hill adjoining town near the College seat." Anderson, for "most cogent reasons," advertised his half interest for sale at $\$ 2,500$ cash or $\$ 3,250$ in negroes, land warrants, young mares or geldings. Season 1808 at R. C. Foster's. Sold South, brought back and died 1814 in Williamson County, property of HaI Cook.

\section{Still Other Good Stallions}

\section{Other stallions of this decade were as follows:}

Big Quicksilver, by Quicksilver, dam by Shakespeare. Owned by Simeon Buford; 1806 at Nashville; 1808 at Lower Ferry.

Bloody Flag. Advertised by Simeon Buford to stand at Lewis Demoss' on Big Harpeth, 1808 . Buford says he "was by my celebrated horse, Union, out of the dam of President."

Buoy, alias Buford's Defeat. Advertised by John Park and David Barclay to stand 1807 , "two miles east of Jefferson"; few best mares $\$ 50$; highest price of all stallions of this decade - except Truxton in one year. Judge William Williams said this horse was by Janus and got his name from his owner, Bowie. This Bowie was probably a member of the famous family of Bowieknife fame that lived awhile (according to Cisco's "Historic Sumner County") near James Cryer's farm in Sumner County. One member, at least, of this family was a breeder in Mississippi or Louisiana in after years.

CADE, by imp Fearnought, foaled 17-; died in Tennessee, aged 5 years.

Chanticleer, by old Chanticleer; foaled i798; died in Tennessee, the property of Richard Jordan.

Dragon (Cage's), by imp Dragon, dam by Truxton. Bred and owned by Reuben Cage, of Sumner County.

EcLIPSE, by Hall's imp Eclipse, dam Phebe descended from Regulus and Snake; Maryland horse; 1806 at R. C. Foster's; 1808 at John Cockrill's "one and one half miles from Nashville on the Natchez road" - now Centennial Park. B. Bosley owned this horse at one time.

Fitz Medley, by imp Medley, dam by Symmes' Wildair; g. dam by Dandridge's Fearnought; I804 at "Weakley's" in Davidson 
County; I805 at "I. Hoopers," same county; died I805. "He was grey and very fine."

Grey Diomed, foaled i802, by imp. Diomed, dam by Flag of Truce; bred and owned by Daniel Barksdale "of Tennessee" - probably Montgomery County.

President, ch. by Celer, dam by Mark Anthony. Owned by Simeon Buford, Nashville; 1807 at the upper ferry in charge of a "careful young man"; 1808 at Jesse Mayfield's "on the Franklin road near Judge Overton's." Buford boldly affirms in his advertisement that President beat Truxton in a 4-mile heat race at Clover Bottom "with 160 on each" and in Warren County, Kentucky, with "I 50 on each" - a quarter race.

Rodney, imp, foaled 1790, by Paymaster dam Nina by Highflyer. Imported into Virginia. Said to have stood in Tennessee. Paymaster sired the winner of the St. Leger in 1786.

Young Diomed, ch. foaled 1804 ; by imp Diomed, dam Bellona by Wildair. Owned by Jesse Westmoreland; I 808 at Samuel Shannon's 8 miles north of Nashville.

Young McKinney Roan, by old McKinney Roan by Celer. As property of William Roberts stood I 807-08 at John Shute's, William Simpson's and Col. Joel Lewis', Davidson County. Season payable "in produce, cotton, pork, beef, corn, rye, wheat, oats, whiskey or brandy."

A communication from Judge William Williams to $T$ the Turf Register stated that Bryan O'Lynn and Dragon stood in Tennessee in the years named, and that the following named horses stood in Tennessee - years not remembered - between 1805 and 1826 :

Bompard, foaled about 1796 , by imp Obscurity, dam by imp Fearnought; - by imp Janus.

Dungannon, imp b., foaled I793; by Dungannon, dam by Conductor; - by Blank; - by Crab. H. M. E. Imported in 1799 by J. Tayloe of Va. Stood in Sumner County.

Heron, imp gr., foaled 1792; by Young Herod son of OId Herod dam by Conductor; g. dam by Florizel; - by Matchem. Imported 1790 by John Hoomes of Virginia. Stood in Davidson County.

Highlander, imp gr. foaled 1783; by Bordeaux out of Tetotum (winner of The Oaks in 1780) by Matchem. Imported into New York in 1794 . 


\section{Hardy Tennessee Pioneers}

Tup, imp b. foaled 1796; by Javelin out of Flavia by Plunder by

Herod. Stood at R. C. Foster's.

VolunteER, imp ch. by Volunteer, dam by Whipcord own brother to Woodpecker. Bred by Col. O'Kelly. Imported 1794 by CoI. John Tayloe, of Virginia. Stood in Rutherford County.

In two letters written from "Poplar Grove," in 1856 , and printed in "Frank Forester's," "The Horse of America,” Vol. I, pp. I40-I48, Judge Williams mentions as standing in Tennessee in early times - years not given these horses not elsewhere included in the author's list:

BucePhalus, b., foaled about 1795; by Symmes' Wildair, dam by imp Shark; - by imp Medley; - by imp Fearnought. Bred by John Jones of Virginia, and owned by Col. Ed Ward.

Dromed (Ragland's), ch., foaled I8or; by imp Diomed dam Silverheels; - by imp Janus; - by imp Fearnought; - by imp Jolly Roger. Bred by L. Ragland of Virginia.

Dromed (Second), called Randolph's; gr. foaled about r8or; by imp Diomed dam by imp Clockfast; he by Gimcrack dam by Regulus. Bred by William Randolph of Cumberland County, Virginia.

Dromedon, b., foaled I 803; by imp Diomed, dam by Hobb's Augustus. Bred by Capt. Ben. Ward of Nottoway County, Virginia.

Wildair (Weakley's), b. foaled i79I; by Symmes' Wildair, dam by Fearnought.

Judge Williams' list included, also, the following named horses that cannot be identified: Cross' Jupiter by Janus; Lewis' Comet by Harry Hill's Janus; Blakemore's Sterne; J. Thompson's Celer out of a Bellair; imp Childers - the "imp" doubtless error - and Suwarrow, said to be from Kentucky. There were three Jupiters by Janus.

Stallions Between i8io and i820

The most distinguished stallions of this decade were Top Gallant, Wilkes'Wonder, Tennessee Oscar and Pacolet.

Top Gallant, a black legged bay, by Gallatan (best 
son of imp Bedford), dam by Symmes' Wildair; - by Black-and-All-Black; - by King Herod; - by imp Partner; - by Apollo. Bred by Hon. Thomas Blount of Jones County, Georgia, and purchased from him by Col. George Elliott about 1812 and stood until 1817 , or longer, at his farm. He was then sold, possibly to Kentucky. Elliott paid $\$ 1,500$ for Top Gallant as a colt - a large price for the time.

WoNDER, first named Hazard and later called Wilkes' Wonder, and sometimes Little Wonder, was by imp Diomed; dam Mary Gray by Tippoo Saib (he by the Lindsay Arabian); - by Goode's Brimmer; - by imp Silver Eye; - by imp Valiant; - by imp Jolly Roger; imp Mary Gray by Roundhead.

Silver Eye by the Cullen Arabian; Valiant by Dormouse.

Wonder was foaled about 1800 and was bred by Francis Eppes of Chesterfield County, Virginia.

At Newmarket, Virginia, the spring he was four years old Wonder ran and won his first race. He lost his second because of a mistake made by his jockey, and ran second in his third race although laboring under the strangles. The next year he ran only five races, viz., Newmarket, Smithfreld, Norfolk, Warrenton and Belfield, but won all of them. Among the horses he defeated was Monticello, bred - if not then owned - by Thomas Jefferson, and another horse by Diomed. The next spring he covered 75 mares and that fall defeated the famous Bumper and Agnes (both by Bellair) in a 4-mile heat race at Belfreld "hard in hand" when the track was knee deep in mud and water. At Norfolk he contended with Eolus by Bedford, Top Gallant by Druid and Monticello and Bumper, in a 4-mile heat race. He won the first heat, lost the second to Eolus by a head, the third by a few feet and the fourth by reason of a plate slipping. 
Wilkes bought Wonder after his second race and owned him when he ran his last. After that he was brought to Tennessee and stood at the farm of Rev. Hubbard Saunders, in Sumner County. Wonder's pedigree and performances as here given were taken from a handbill issued by Rev. Hubbard Saunders advertising Wonder for the season of 1813 .

Wonder died at Franklin in February, 1815, the day after arriving there from Sumner County. James Hicks, of Franklin, stood a chestnut horse from Virginia named Wonder by Diomed, in 1808 , but he is said not to have been the Saunders horse.

Wilkes' Wonder was a chestnut about is hands, and one inch high. His thigh was "rather lean for beauty but not for action. In every other point he was perfect," said Rev. Hubbard Saunders. He contributed greatly to the blood of Tennessee stock. His son, Young Wonder, was a fine horse and his daughter, Bet Bosley, was a famous brood mare whose name appears often in latter day pedigrees. Hazard, another daughter, was a fine brood mare, owned by Alex Ewing, of Davidson County.

Pacolet, dapple gray, $15 \frac{1}{2}$ hands high, foaled in 1806 , was bred by Francis Eppes, of Virginia; sold for $\$ 179$ to Col. W. R. Johnson who trained and ran him in all the races he ran before coming to Tennessee, where he was brought by Gen. Andrew Jackson at a cost of $\$ 3,000$ to beat Haynie's Maria. He was by imp Citizen dam Mary Grey by Tippoo Saib. See Wonder.

Citizen was by Pacolet by Blank; his dam Princess by Turk by Regulus; his g. dam Fairy Queen by Young Cade, he by Old Cade; his g. g. dam Black Eyes by Crab, out of the Warlock Galloway, by Snake; - by the Bald Galloway, etc., to the Byerly Turk.

Citizen was foaled in 1785 . He was 15 hands and one 


\section{Making the American Thorougbbred}

inch high. He won 19 races in England; 14 of them 4 -mile races; 6 of them he won at three heats, beating the best horses in England, and is said never to have lost a race when the heats were broken. He was sent to the West Indies, thence imported into North Carolina in I803. In six years he covered 508 mares at \$28 each, and netted his owner \$ro,ooo. He sired the dam of Sir Charles and the dam of Stockholder. His cross was highly esteemed in Tennessee. He died and was buried at Oaklands, the home of Col. W. R. Johnson, according to one authority; Bruce says he died in Tennessee in 1809 .

In I8I4 and I8I5 Pacolet was advertised by Gen. Andrew Jackson, Col. Edward Ward and James Jackson to stand at J. W. Clay's. In I816 he was advertised by his owners, James Jackson and John Childress (or Childers) to stand at Clay's. In I8I he stood at "the Flat below Nashville." Later he was taken to Mississippi but was brought back to Tennessee in I82I or before as the property of Col. George Elliott, and stood at Elliott's farm until his death about 1825 or 1826 . Service \$20; \$40. Pacolet was the sire of many horses and mares famed for their performances and their offspring.

"Citizen," wrote Judge Williams, "had more accurate proportions and higher finish - a more game, Arabian look and carriage than any native or imported that I ever had the pleasure to look upon. Pacolet had the Arabian air but wanted something of his sire's finish in the shoulder. Yet his bearing was proud and lofty."

\section{Other Distinguished Horses}

Other stallions that stood in Tennessee during this decade were: 
Bashaw, by Grand Arabian; foaled in 1795, died in Tennessee 1819 the property of Mr. Ball (or Bell?) of Virginia.

BoAster, imp. b. foaled 1795; by Dungannon, dam by Justice. Imported in 181 I by Walter Bell of Winchester, Virginia, from whom he was purchased; 18 16 at John Harding's on "old Natchez road"; \$25; \$40; I8I9 at Henry Wade's $6 \frac{1}{2}$ miles southwest of Nashville. Died same year.

BRyAN O'LynN, foaled 1796; by Aston dam by Le Sang; - by Regulus. Le Sang sired the St. Leger winner of 1777. Bryan O'Lynn imported into North Carolina by Gov. Turner. Stood at J. Shute's, Davidson County, I8I I-12. Died in Georgia.

Coneueror, b. foaled 1808; by imp Wonder (Cripple), dam by imp Saltram. H M E. Stood 1815 at Henry Cook's, Williamson County; \$40; 1829 at Hollan Davis', Williamson County. Died 1830 .

Cook's Bellair, son of Tayloe's Bellair, dam by Hickman's Independence son of Fearnought. Williamson County.

Dragon, imp ch., foaled 1787; by Woodpecker, out of Juno by Spectator; - by Blank; - by Childers. Imported by CoI. John Hoomes of Virginia. Stood at R. C. Foster's, I8I I-I2. Died r812.

Florizel (formerly Grey Tail) foaled i8ı ; by Ball's Florizel, dam by Wildair. Property of W. B. and George Tankesley; I 8 I9 at James Ridley's stable, "Pacolet's old stand," at the "lower ferry;" Nashville; I826, as property of John M. Robertson, stood at Joseph Scales' south of Nashville and at John Criddle's, McGavock's ferry.

JACKson, dk. ch.; by Wonder, dam by Nutall's Whiskey (by imp Saltram) out of a Bellair mare; I815 and 1816 at Dr. Roger B. Sappington's, Nashville; \$I 6 .

MessinA, advertised by Dr. Roger B. Sappington to stand 1819 at John Harding's; pedigree not given. Cannot find this horse in Stud books. Probably Massena by imp Citizen; or the one by Pacolet, dam by Ragland's Diomed.

Oscar (Tennessee). See Peyton's "Reminiscences," No. 8. In advertising Oscar to stand season 1819 at his farm "adjoining" Nashville (service \$20.) Dr. Roger B. Sappington, his then owner included certificates from prominent men who saw Oscar win one or more of the races referred to by Peyton. These men were Giles Harding, John Harding, Peter Randolph, Henry Wade, Alex Ewing, William Carroll, Dr. John Shelby and John C. Hicks. Dr. Shelby and Dr. McNairy diagnosed Oscar as the swiftest 


\section{Making the American Thorougbbred}

horse in the United States. In I 822 Oscar stood at Edwin Smith's three miles south of Nashville "on the main road to Franklin." After that he stood in Sumner County. Among his get were Prosperine, Napoleon, Columbus, Josephine, Bolivar and other fine runners.

Phoenix. There were two horses of this name on record as standing in Tennessee. One, according to Judge Williams, was "by Venetian, imp dam Zenobia, by Don Carlos, from Maryland." The other was by Dragon, dam Portia by Volunteer; - by King Herod. Imported into Virginia and died in Montgomery County, Tennessee, in 1819. Portia and another of Volunteer's get won The Oaks and Spread Eagle by Volunteer won The Derby. See EAgLE. Stump the Dealer, by imp Bryan O’Lynn, dam by Grey Diomed. н Bred by Mr. Alston, South Carolina. Advertised by John T. Macon to stand 1819 at Hugh F. Bell's, near Nashville. Fall season 1829 at N. P. Carter's on Lebanon road.

\section{Stallions From i820 to i 830}

Besides Pacolet and Tennessee Oscar, whose services continued into this decade, the most celebrated sires were Stockholder and Timoleon.

Stockholder, b.; by Sir Archy, dam by imp Citizen, g. dam by imp Stirling; - by imp Mousetrap;- by Harris' Eclipse; - by imp Janus; - by imp Fearnought; — by Apollo; - by imp Partner; - by imp Silver Eye;by imp Jolly Roger; out of imp Mary Gray by Roundhead. Stirling descended from Highflyer, Herod, the Byerly Turk and Place's White Turk.

Stockholder was bred by Henry Cotten of Halifax County, North Carolina. He made an "enviable reputation" in Virginia. He was brought from North Carolina to Sumner County by O. Shelby, at a cost of $\$ 6,000$. His first season in Sumner seems to have been in 1825, when he stood at O. Shelby's; in 1826 he stood at Shelby's again. He covered 135 mares his first season in Sumner, I 20 the second and 160 the third. In 1829 he stood at the farm of Rev. 
H. M. Cryer; in I834 at Stockley Donelson's, Hermitage; $\$ 40 ; \$ 60$; in 1835 at William Pillow's three miles southwest of Columbia. Thomas Barry, of Sumner, owned Stockholder for some time; sold him to Long Brothers of Christian County, Kentucky, for $\$ 4,000$, and they sold him to A. B. Newsom for $\$ 4,500$. Newsom took him to his farm and had his pedigree registered in the office of the Register of Deeds of Wilson County. In I833 eight of Stockholder's get won 14 races, running 31 heats and 71 miles. In 1836 , seven won 14 races, running 25 heats and $75 \frac{1}{2}$ miles. In 1837,16 of his get won 18 races, running 37 heats and 53 miles. From 1832 to 1840 , inclusive, his get won I 2 races. As brood mares Stockholder's daughters rivaled Pacolet's.

Timoleon, foaled i813; by Sir Archy, dam by imp Saltram, g. dam by Symmes' Wildair; - by imp Fearnought; - by imp Driver; - by imp Fallower; - by imp Vampire. Wildair's dam was by Jolly Roger. Driver's grandam was by Herod. From other sources, also, as previously shown, Timoleon inherited the blood of Herod; also of Matchem; and from several sources the blood of O'Kelly's Eclipse, the two Childers, etc. FaIlower was by Blank, out of a Partner mare; Vampire was by Regulus, second dam by Partner.

Timoleon's hind quarters appeared higher than his forehand in which respect, as well as in others, he bore a strong resemblance to his great grand-sire, O'Kelly's Eclipse. It was this peculiar conformation in Eclipse, together with his uncommon strength, that put his agility and stride upon a par.

Timoleon was I 5 hands 3 inches in height; a light chestnut, his only mark a small star in the forehead. He was bred by Benjamin Jones of Greensville County, Virginia, and ran only in his third and fourth years. 


\section{6o Making the American Thorougbbred}

In $18 \mathrm{r} 6$ he won the sweepstakes over the Petersburg, Virginia, course, mile heats in $\mathrm{I}: 47$ and $\mathrm{I}: 48$. In the same year over the same course he and Reality ran three heats of two miles each in 3:47, 3:48 and 3:49 - won by Reality. In 1817 over the same course they ran both heats of four

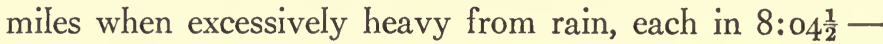
won by Timoleon.

In February, 1818 Timoleon, owing to an accident, was stopped and for that reason was beat. This was the Iast race he ever ran, having proven himself the swiftest horse in Virginia - the victor over Reality and Lady Lightfoot. AII in all he started in seventeen races, won nine, "walked over" for four and lost two.

At three years old Timoleon was sold to Col. William Wynn of Petersburg, Virginia, for \$2,500; the next year Col. Wynn sold him to Robert R. Johnson, brother of CoI. W. R. Johnson, for $\$ 4,000$, and ten days later offered $\$ 5,000$ to get him back, believing him "superior to any race horse that ever turned a gravel on any race course in the United States."

After Timoleon broke down he stood at Wynn's and Johnson's stables and in 1819 was sold for $\$ 4,300$ to CoI. David Dancy who later moved to Madison County, Alabama, taking Timoleon with him.

In 1829 Timoleon, still the property of Col. Dancy, stood at the Nashville race track "two miles below town" in charge of William C. Davis, proprietor of the track; service $\$ 30 ;$; 5 . In 1831 and 1832 he was back in Charles City County, Virginia, where, in the latter year, he got a certain horse named for a popular card game of that period - Boston.

After his brother had sold Timoleon CoI. W. R. Johnson, who had seen him run all his Virginia races, wrote that his performances at "from one to 4-mile heats would do 
credit to the best runner in this country or in Europe; and his style of going, the most superior action, his size and blood, entitle him to rank first rate as a stallion." Results confirmed this opinion. Timoleon's son Washington, at three years, beat the famous Henry, same age, in four heats, and was the best 3-year-old of that year. Another son, Hotspur, won all his races except the one in which he broke down to Flirtilla. His daughter, Sally Walker (dam by imp Dragon), was superior to all other racers of her time except Mons. Tonson.

"Frank Forester" said Timoleon was the "best son of Sir Archy and progenitor of half the best horses in the country of the present day" - 1857 .

In I838, I I of Timoleon's get won 20 races, running $4 \mathrm{I}$ heats and 120 miles. In the same years that Stockholder's get won i i2, Timoleon's won iri. Timoleon's reputation as a sire appears to have been founded on the performances of a comparative few of his get, - chiefly the performances of Boston.

Boston was foaled in Henrico County, Virginia, the property of John Wickham, the eminent jurisconsult, of Richmond. At two years of age he was sold to Nathaniel Rives, of Richmond, for $\$ 800$. In May, I839, he was sold to James Long of Washington, D.C., for \$12,500. Long subsequently sold half interest in him to Col. W. R. Johnson. Boston was first trained by Capt. John Belcher, 1836-37; after 1838, by Arthur Taylor. His first jockey was Cornelius, a negro boy; his second Gilbert W. Patrick, and his third, Craig.

His dam was by Ball's Florizel who never paid a forfeit and who, without feeling the touch of whip or spur, won every heat of every race he ran. His grandam was by imp Alderman by Pot8os; his g. grandam by imp Clockfast. Boston was a trifle over $15^{\frac{1}{2}}$ hands high, a chestnut 
with a white stripe down his face and white stockings on his hind feet. After he got on familiar terms with fame he was called "Old White Nose." He had no beauty to brag on, but in strength, substance, bone and speed he was a prodigy. Time and time again did the proprietors of race tracks persuade his owners not to run him, as his entrance into any contest would destroy the sport. His owners offered to bet several English sportsmen $\$ 50,000$ to $\$ 40,000$ that he could beat any horse they could bring from England. Declined. He started in 45 races, won 40, 30 of which were of 4-mile heats, nine 3-mile heats, and one 2-mile heats. Up to December, 1841 , his winnings amounted to $\$ 49,500$. In $\mathrm{I}_{4} \mathrm{I}$ i he covered 40 mares at $\$$ Ioo each. He won several races in 1842 and then retired from the turf sound and free of blemish. His career in the stud was no less remarkable than his success as a racer. In 1853,27 of his get won 56 races, I3 1 heats, 230 miles; in 1854, 21 won 50 races, 109 heats, $245^{\frac{1}{2}}$ miles. "The Turfman," wrote Hamilton Busbey in Harper's Magazine in 1870, "judges a horse by his blood, his form, his deeds, and his produce; and judging by such, Boston is pronounced the greatest race horse that America ever produced." His right to first place in the Hall of Fame would have gone unchallenged but for the career of his own great son, Lexington; - this has occasioned difference of opinion among horsemen. It was through Timoleon, Boston and Lexington that the Archy blood was mostly transmitted to Tennessee thoroughbreds of the post-bellum period. All of Capt. James Franklin's foundation mares at "Kennesaw" were by Lexington, notably Nevada, dam of Luke Blackburn, sire of Proctor Knott. Gen. Harding thought Lexington a greater sire than any predecessor. ${ }^{1}$

${ }^{1}$ For sketch of Lexington see Addenda E. 


\section{Hardy Tennessee Pioneers}

\section{Other Noted Stallions}

Next to Pacolet, Stockholder, Tennessee Oscar and Timoleon the most celebrated stallions of this decade were:

BAGDAD, brown horse of purest Arabian blood. Sold by Hassana de Gris, Minister to England from Tripoli, to George Barclay of New York, from whom he was purchased in 1823 by John Harding, representing a company of Nashville men, of which William Williams was Secretary. Price paid, \$8,00o. Season 1830 at Thomas Martin's, four miles on the Gallatin road; 1835 at Thomas AIderson's stable, Nashville. Bagdad sired several good horses but most sportsmen of that period preferred the Archys and Pacolets, and fought Bagdad.

Bluster, imp dk. b., 16 hands, foaled 1808 ; by Orlando (son of Whiskey) dam by Pegasus; - by Highflyer. His fifth dam was Herod's dam. Whiskey by imp Saltram, out of Calash by Herod. Imported into Virginia; 1826 at Giles Harding's, 7 miles southwest of Nashville. Died 1828. Whiskey sired two winners of The Oaks.

Constitution, dk. s., foaled about i 805 ; by imp Diomed, dam by imp Saltram. Stood $1825-26$ at John Shute's. "Owing to the hardness of the times he will be suffered to serve at \$25." Died 1827 in Bedford County.

EAGLE, imp b., foaled 1796; 16 hands high; got by Volunteer out of a Highflyer mare. Bred by Sir Francis Standish. Imported into Virginia in 1812 by Mr. Bell. Season 1821 at Henry Wade's. Advertised by Montgomery Bell to stand season 1822 at John Harding's, Belle Meade. Eagle was a "short-race" horse but was very fleet. His winnings in England amounted to \$933,373. He was full brother to Spread Eagle, who died in Kentucky in 1805 , Eagle died in Kentucky in 1826 . See Phoenix. To show Montgomery Bell's enthusiasm for the thoroughbred this extract is made from his advertisement of Eagle, dated Dec. 15, 1821: "Eagle combines more power and beauty than any horse on earth - more even than human mind can imagine."

Muzzle Diomed, by imp Diomed, g. dam by imp Fearnought. Said to have been first colt got by his sire after coming to America. Bred by Col. William NeIson, Caroline County, Virginia; 1820 at Samuel Savage's three miles west of Columbia. Died in Georgia. 


\section{Making the American Thorougbbred}

Napoleon, ch. s., foaled 1815; by Sir Archy, dam by imp Sir Harry (winner of The Derby in 1798) son of Sir Peter Teazle; grandam by imp Dare Devil. Bred in Virginia; purchased by Col. George Elliott and stood in 1825 , and until his death in 1830 , at Elliott's farm. Wallace says Napoleon's grandam was by Chanticleer.

Peacemaker, by imp Diomed, dam by Black-and-All-Black (Othello); foaled I8or; bred in Virginia; sold to General Greer of Tennessee and stood here in his latter years. He died in 1827 .

Sir William (Clay's), ch. foaled 1816; by Sir Archy, dam Bellona by Bellair. Brought from Virginia to Tennessee; 1829 at J. W. Clay's, near Lebanon road.

Sir William (Richardson's) by Ball's Florizel, dam by imp Clifton; her dam by Old Celer. Bred by Gov. J. B. Richardson of South Carolina; 1829 at Jubal Richardson's near Newsom's Mill on Big Harpeth. This pedigree is from Jubal Richardson's advertisement. Other authorities say he was by Sir Archy.

Young Truxton, dk. b., I6 hands I inch high. Advertisement in Nasbville Wbig of 1822 signed by Gen. Andrew Jackson says: "Young Truxton was got by my celebrated running horse, Truxton, dam by Young Wildair, grandam by imp Master Stevens out of Capt. Alexander Ewing's fine brood mare."

The General announced, furthermore, that Young Truxton would stand that season "at my stable where I now live" half of the season and the other half at the farm of the widow of William Donelson, ten miles from Nashville, on the Gallatin road. AIso that the charge for service would be " 300 pounds of good merchantable seed cotton or $\$ 18$ in cash."

Other good stallions that stood in Tennessee between 1820 and 1830 were:

Bay Diomed, by imp Diomed, out of a Wildair mare; 1825 at Maj. Colin Campbell's, Carter's Creek, Maury County.

Cumberland, gr., by Pacolet, out of Virginia by imp Dare Devil. Bred by James Jackson. Sold to Mr. Hyde of Davidson County. NAShVille, by Oscar, out of a Pacolet mare; 1829 at stable of Joseph T. Elliston, Nashville.

Sir JAMES, ch. s. 16 hands high; by Ball's Florizel, dam by Madison. Bred by Maj. Wm. Gaines of Virginia; 1826 at James Dabbs,' 4 miles east of Nashville. 


\section{Hardy Tennessee Pioneers}

Washington, by Pacolet, out of Rosey Clack. At O. Shelby's, Sumner County.

Young Medley, by Harris' Young Doublehead. Owned by Henry Wade \& Co.; 1829 at Robert Hills, Hillsborough, and several places in Davidson County.

Young Wonder, by Wilkes' Wonder. Stood at Wm. D. Phillips, seven miles north of Nashville and at David McGavock's ferry stable, in 1829. Phillips' advertisement said Young Wonder's dam was by Buford's President. ${ }^{1}$

${ }^{1}$ For other information of Tennessee horses mentioned in this chapter, and others of early days not mentioned, see Addenda D. 


\section{Chapter V}

\section{KNEE DEEP IN CLOVER}

IN the breeding and turf interests of the United States, as a whole, the decade beginning with 1830 is marked with several interesting features: (I) increase in growth and popularity; (2) the continuation of the Archy family's monopoly; (3) the continuation of the rivalry between Archy and Eclipse stock; (4) the beginning of a long contest between the advocates of native and imported stock; and (5) the rise and supremacy of imp Leviathan. How Tennessee stock profited by these conditions will be told in due order.

As far as the records show, from August, 1829, to September, 1834 , the get of only six imported stallions in the United States were among the winners, and these get won only is races. This supremacy of native stock was due almost entirely to Sir Archy and his numerous sons. They enjoyed a monopoly that is without a parallel, except that of the Godolphin Arabian and, perhaps, that of Lexington. This monopoly began in the early '20's, before the records were kept in detail, and continued until 1840 or later. A few illustration will suffice.

Forty-two native stallions were the sires of 137 winners of 234 races run between August, 1829, and December, 1830. Of these Sir Archy and 20 of his sons were the sires of 99 winners of 170 races, leaving the other 21 horses with 38 winners of 64 races.

Thirty-one of Sir Archy's sons were the sires of 186 
winners of 4213 -mile and 4 -mile heat races run in the seven years between 1829 and 1837 . The other 30 stallions, native and imported (named in the table printed in The Spirit of the Times, from which these figures were taken), that were not sons of Sir Archy, were the sires of 91 winners of 1763 -mile heat and 4-mile heat races.

Of the 160 stallions advertised for service in the United States in the spring of 1839 , Sir Archy got 21; was the grandsire on his sons' side of 43 and the grandsire on the dams' side of 13 - in all 77 of the I I 5 native bred stallions were Sir Archy's sons or grandsons.

Although the Archy blood showed no signs of giving out, and although good 4-mile horses in England were limited to a very few, many breeders believed that the infusion of new blood would be advantageous; and between 1830 and 1840 many importations were made into the several states. Chief among these "progressive" breeders - and they were merely harking back to the old days - were James 'Jackson and CoI. George Elliott. They had a hard tussle with the "reactionaries" of the Archy-Pacolet school, strongly entrenched, as these "reactionaries" were, behind the good results of Iong experience. This faction was largely in the majority in Tennessee and remained so for several years. Jackson and Elliott knew the power of the opposition, but followed their own bent, nevertheless. They met their opponents always on half-way ground and a few years' experience demonstrated the soundness of their judgment - if immediate results are to control. The Archy family, as such, continued their supremacy over every other family and over many families together. But as between particular individuals of the Archy tribe and particular importations, the Iatter soon won recognition as the equals and, in many instances, the superiors of the 
former; and the offspring of these importations were actually permitted to graze in the same pasture with the Archys and Pacolets and romp and play on terms of perfect equality. The success, as sires, of several of these early importations brought others from year to year, and in 1840 the foreign horses, not one-fifth in number, did more than one-half in performance. This according to "Frank Forester" who, in summarizing his tabulations in 1857, said: "It is indisputably proved by the above that a far less number of imported stallions have got a far greater number of winners than the American stallions, in the last eight and twenty years. And further, that the winning stock of the English stallions have won rather a larger number of heats and run a greater number of miles, each for each, than those of the Americans."

Whether these results were attributable entirely to the new blood or, in part, to the "old reliables" with whom the imported horses were mated, is a question the writer leaves to others, while he keeps to the main point, viz.: the effect the conditions set forth above had on the Tennessee stock.

Between 1825 and 1840 Sir Archy contributed to the Tennessee stallion class 17 sons, I4 grandsons in the male line and 6 in the female line-all in the stallion class. His mares not counted. So much for the Archy monopoly. American Eclipse and six of his sons stood in Tennessee - so much for the rivalry between the Archys and Eclipses. To show the merit of other horses whose blood permeated Tennessee stock some comparisons must be made. The facts stated are frshed out of "Forester's" tables which were compiled from reports in The Turf Register to show the relative rank of native and imported stallions, in the aggregate. "Forester's" tables differ somewhat from those printed in The Spirit of the Times, 


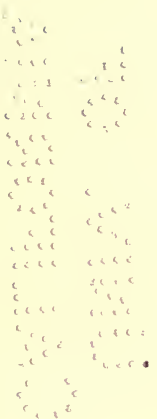


upon which the writer relies for some of the statements concerning races in certain years won by get of certain stallions. But both sets of tables are accurate enough for present purposes.

\section{Rank of American Stallions}

From August, 1829 to September, I833, and again from September, 1835 to September, 1836 Sir Charles' get won more races than the get of any other stallion in the United States. Sir Archy was second in three years, Bertrand in one and Eclipse in one. From September, 1833 to September, I834 Mons. Tonson led as sire of winners during that year. Bertrand was second. From September, 1834 to September, I835 Bertrand led; Mons. Tonson second. From September, 1836 to September, I837 imp Leviathan led. Sir Charles had one more winner but one less of races - the number of races won being the standard of excellence here adopted. In I838 Leviathan led; Eclipse second. Leviathan first in 1839; Medoc (by American Eclipse) second. In 1840 Medoc led; Leviathan second. So it was in $184 \mathrm{I}$. In $1842 \mathrm{imp}$ Priam advanced to first place; Eclipse second. In 1843 Leviathan was first; Priam second. Their places reversed in I844. In 1845 Priam led; imp Emancipation second. In I846 Priam Ied; Leviathan and Glencoe had each I5 "winners." In I847 Glencoe led, Wagner second, Leviathan third. In 1848 Leviathan was first, imp Trustee second, Wagner third. In I849 Glencoe led, Leviathan second. Glencoe first again in 1850; Grey Eagle second. In 185 I Boston led, Grey Eagle second, Wagner third. Boston first again in 1852; Glencoe second, imp Sovereign (by Emilius) third, Wagner fourth. In I 854 Glencoe Ied, Boston second, Wagner third, Grey Eagle fourth. In 1855 Glencoe led, Wagner second, Boston third. 


\section{Making the American Thorougbbred}

In "Forester's" table of "winners" for each year this word is used as a synonym of "horses," as shown by the excess in the number of races won over the number of "winners." But when, for brevity, we aggregate these "winners" for a long period of years we have many more "winners" than the number actual of horses, for the reason that the same horses won in many different years.

Leviathan's get first appeared on the turf in the year beginning September, I833, when he had 6 winners of 6 races; they appeared last in 1852 when he had 2 winners of 2 races. His best year was 1838 , when his get won more races than the get of any other horse (that stood in the United States) won in any one year between 1829 and 1855. Thirty-four of his get won 70 races, running 140 heats, and 263 miles. As to the number of winners, Leviathan's best year was I840, when he had 37, but they won only 54 races. The best period of his career was from 1837 to 1843 , inclusive, when the number of his get that won each year ranged from 20 to $37-$ an average for the seven years of about 27. During the entire period from September, 1833 to 1852 , inclusive, 298 of Leviathan's "winners" won 450 races, running 980 heats and I, 8 I 5 miles. ${ }^{1}$

American Eclipse had been in the stud seven years

1 In the supplement to "Skinner's Stud Book" is a list of "Winning Horses Since 1839." The dedication in this supplement is dated January I, I848; copyright notice same year. It contains tables showing the best time at various distances, the latest year of any race record therein given being 1846 . The original and supplement are both printed in one volume bearing the date 1857 on the title page. The date at which the list of winners closed is therefore indefinite. A count of the horses shows that Leviathan had 119 get that won, Medoc 74, Luzborough 44, Eclipse 43, Bertrand 33, Priam 32, Glencoe 23. The number of races won by each winner is not stated. 
when Leviathan was imported, and he served throughout Leviathan's lifetime. From August, 1829 to 1853 , inclusive, 221 "winners" by him won 358 races, running 884 heats and $1,700 \frac{3}{4}$ miles. His best year during the period mentioned was 1838 , when 25 of his get won 53 races, running 125 heats and 225 miles.

Glencoe's get came on the turf in $184 \mathrm{I}$ and continued for several years after the year when "Forester's" tables close - 1855 . His best year during the period indicated was 1854 , when 26 of his get won 56 races, running I 14 heats and 222 miles. During this I5-year period I84 "winners" by him won 329 races, running 779 heats and I,534 miles.

During the is years that Priam's get were on the turf, I838-1853, I30 "winners" by him won 226 races, running 492 heats and $867 \frac{1}{2}$ miles. His best year was 1842 , when 24 of his get won 53 races.

During 16 years that Trustee's get were on the turf, I 840-1855, inclusive, 90 "winners" by him won 165 races, running 374 heats and $804 \frac{1}{2}$ miles. His best year was 1848 , when 8 of his get won 19 races; his next best year 1843 , when 10 of his get won 17 races.

Next in order of merit among imported horses was Luzborough who, from 1837 to 1844 , inclusive, had 82 winners of 146 races, his best year being 1840 , when 27 of his get won 52 races, running 120 heats and 213 miles.

Then there was Sovereign who, in seven years, I 846 and 1847 , and from 1851 to 1855 , inclusive, had 40 "winners" of 84 races. And Margrave who, from I 840 to 1855 , inclusive, had 54 "winners" of I 19 races. And Ainderby who, from 1843 to 1854 , had 25 winners of 37 races. And Autocrat who, from 1838 to 1843 , had 29 winners of 33 races. 


\section{$74 \quad$ Making the American Thorougbbred}

successful in three contests in 1818 and $1819-$ one 3-mile and two 4-mile affairs - he was placed in the stud at $\$ 12.50$ the season, in 1820 , and stood again in $182 \mathrm{I}$, covering 87 mares the latter season. The New York legislature, after Eclipse had been withdrawn from the turf, modified the laws relating to racing; a society was formed to improve the breeding of horses and Eclipse was returned to the track in 1821 . After winning four 4-mile heat races of lesser note he met Henry (by Sir Archy) in a match race for $\$ 20,000$, after which he was returned to the stud at $\$ 75$ and $\$$ ioo. After the death of Sir Charles, for whom three offers of \$15,000 each had been refused, Eclipse was purchased at $\$ 10,000$ to take Sir Charles' place, and stood at Boydton, Virginia, Baltimore and other places in the South. He died in Kentucky July I0, I847.

As previously indicated Medoc was among Eclipse's most distinguished get. He was foaled in New York in I 829 and sold to Kentucky in I833. Another was Mingo, foaled in Pennsylvania in I83 I and taken to Kentucky in 1839, where an offer of $\$ 5,000$ for one fourth interest in him was declined. Two others were Ariel, dam Young Empress by Financier; and Black Maria, dam Lady Lightfoot by Sir Archy. Ariel won 42 out of 57 races, I 7 of the 42 being of 4 -mile heats. Black Maria frequently ran when out of condition. Of 25 races run she won I3, I I of which were of 3 -mile and 4-mile heats, and in one of which she had to run 20 miles to win. Time 8:06 - 7:55-8:13 - 8:39-8:47. Other distinguished get were Goliah, Lance, Shark, Monmouth Eclipse, Gano, Lady Jackson, Ten Broeck, and several that stood in Tennessee.

Of the 160 stallions standing in the United States in I 839 Eclipse was the sire of $2 \mathrm{I}$ and the grandsire on the dam's side of $\mathbf{I}$. 


\section{A King from a King's Stable}

"Leviathan was foaled i823; got by Muley; his dam by Windle; - g. dam by Anvil; - Virago by Snap; - by Regulus; - sister to Black-and-all-Black, by Crab; Miss Slamerskin, by True Blue;-Oxford Arabian;out of the D'Arcy's Black legged Royal mare.

"Muley by Orville, out of Eleanor, by Whiskey; her dam Young Giantess, by Diomed (later imported); Giantess by Matchem; - Molly Longlegs, by Babraham, etc.

"Windle, by Beninbrough, out of Maryann (sister to Warrior), by Sir Peter Teazle; - Young Marske; Matchem, etc.

"Anvil, by Herod; his dam by Feather, out of Crazy, by Lath; - sister to Snip, by Childers; - Basto Mare (sister to Sore Heels); - Curwen Bay Barb, etc.

"Orville by Beningbrough, out of Evelina, by Highflyer, etc.

"Whiskey by Saltram, out of Calash, by Herod; Theresa by Matchem; - Regulus, etc."

King Fergus got three Doncaster St. Leger winners, Beningbrough being one. Beningbrough got two winners of The Oaks, and one winner of The St. Leger - Orville. Orville got two Derby winners - Emilius being one - and one St. Leger winner. Emilius got two Derby winners - Priam and Plenipotentiary. Emilius also got one winner of The Oaks, and Mango, winner of the St. Leger in 1837. In I80 I Eleanor won The Derby and the next day won The Oaks; she was the first to win both stakes the same year. Muley got one winner of The Oaks and one St. Leger winner-Margrave. Among the nominations for The Derby of 1837 were seven sons of Muley; for The Oaks were four fillies by Muley. 


\section{Making the American Thorougbbred}

Leviathan's family connections were therefore of the best.

Leviathan was I6 hands high, a deep chestnut, "with a peculiar shade of deep red interspersed"; his only mark a narrow blaze. Most of his get followed him in color. He was bred by Mr. Painter and made his debut on the turf in 1825. "At two years old," wrote Col. George Elliott, "he ran two races; won one, and lost one, subsequently beating the winner; at three years old he won nine in succession, and was not beaten; at four years old he ran nine races, won seven; lost one to Dr. Faustus, whom he had previously beaten, and one to Paul Pry (by bolting) whom he had also beaten, and beat afterwards. He was handicapped in this year and ordered to carry 7 Ibs. extra weight over horses of his age, conclusive proof of his superiority."

Only one of these races was of 4-mile heats.

On Sept. I, I827, Leviathan "walked over" in a 3-mile heat race, after which his then owner, Mr. Giffard, sold him to the King of England for 2,000 guineas. On his arrival at Newmarket the King's trainer discovered that his legs were injured. The Duke of Grafton, who conducted one of the finest studs in the kingdom, was anxious to buy Leviathan but he was sent to Windsor and remained idle all during 1828 . In 1829 one experiment showed his career on the turf was over and he was sold to Lord Chesterfield, who stood him the season of 1830 . In that year he was purchased by the Messrs. Weatherby for James Jackson and was placed under the care of Maj. Geo. A. Wyllie (son-in-law of Col. George Elliott) at Lord Chesterfield's. After a tedious passage of $5 \mathrm{I}$ days he was landed at New York on Aug 30, I830, and was taken by Wyllie to his home in Virginia to recuperate. He reached the farm of Col. Elliott on 


\section{Knee Deep in Clover}

Nov. 15, 1830, and remained there until his death in 1846.

The literature of Leviathan's day always spoke of him as James Jackson's property; Jackson returned his name in a list of his stud in April, 1837; and Bruce, who knew Elliott, says Leviathan died the property of the estate of James Jackson. Circumstances indicate that Leviathan was purchased and kept under some sort of partnership arrangement between Elliott and Jackson. Whether Elliott Iater became sole owner, or not, he managed to hold to Leviathan, the results being the same. Jackson sent mares to Sumner County every year to be bred to Leviathan, and later bred Leviathan mares to Glencoe.

Owing to the prejudice existing in Tennessee against all importations Leviathan had a chance to show his popularity in six other states. The two Carolinas, Georgia, Louisiana, Mississippi and Kentucky had to join in with his Tennessee "friends" to give him a full quota of mares his frrst season. He served 102 at $\$ 75$ each and got more than 90 foals. But his first colts were stringy and subjected him to much ridicule from the Archy-Pacolet school. In 1835 he still stood at $\$ 75$, and netted his owners $\$ 10,000$. In 1837 he stood at $\$ 100$; in I839 and the rest of his life at $\$ 150$. After the frrst few years he was limited to a smaller number of mares.

"Of all recent importations," wrote Wallace in I867, "this was the most valuable except it be Glencoe." "Forester" had previously expressed the same opinion. AIthough not noted as a 4-miler himself Leviathan got many 4-milers out of native 4-mile mares. On one occasion Col. Elliott declined an offer of $\$ 7,500$ for two sucklings and a yearling by Leviathan and Thomas Barry declined an offer of $\$ 2,500$ for a yearling, full sister to Angora. Comparisons previously made, showing Levi- 


\section{$78 \quad$ Making the American Thorougbbred}

athan's standing in the United States, as a whole, do not fully signify the point of popularity he finally attained in Tennessee; a rough estimate that he had more winning stock on the turf in Tennessee and farther south, than any other half-dozen or more horses would not be far wrong. Throughout the entire country he was regarded as "the modern Sir Archy." If you don't know the story of Leviathan you don't know the history of Tennessee.

\section{Son of a Derby Winner}

Luzborough, imp dk. b., was foaled in 1820; got by Williamson's Ditto, winner of The Derby in 1803; dam by Dick Andrews; g. dam Eleanor by Whiskey; - Young Giantess by Diomed (afterward imported);-Giantess by Matchem; - Molly Longlegs by Babraham;- by Cole's Foxhunter; - by Partner; - sister to Roxana; sister to Chanter by the Alkaster Turk; - by Leedes' Arabian; - by Spanker.

Williamson's Ditto was by Sir Peter Teazle.

Dick Andrews was by Joe Andrews, he by O'Kelly's Eclipse. Dick Andrews' dam was by Highflyer. Eleanor won 28 of 43 races; Dick Andrews won 20 of 27.

Luzborough won 25 of 36 races run and received forfeits from 585 horses, among them many of the famous racers of England. He lost only one race of heats, when he ran second to Presentiment whom he had beat before and beat afterwards. He generally ran handicapped. At 8 years of age he was withdrawn from the turf and stood three seasons in England where his colts ran with success. In 1832 he was imported into Virginia by Merritt \& Merritt and made two seasons there. He was brought to Nashville in January, 1835 by a company in which L. P. Cheatham was probably interested, as he advertised that Luzborough would stand the season of 1835 at Thomas A. 
Pankey's, Franklin; \$75; \$125. In I837 Luzborough stood at Rev. H. M. Cryer's farm near Franklin, on the Nashville road; \$10o; \$150. He died in Georgia in 1840. Among Luzborough's distinguished get was Portsmouth. Others are named elsewhere.

In announcing the coming of Luzborough to Nashville it was stated that he would be exhibited to public inspection before the legislature adjourned.

\section{The Immortal Glencoe}

Glencoe was foaled i83I; got by Sultan, dam Trampoline by Tramp; - g. dam Web by Waxy; - Penelope by Trumpator; - Prunella by Highflyer; - Promise by Snap; - Julia by Blank; - Spectator's dam by Partner; - Bonny Lass by Bay Bolton; - by Darley's Arabian; - by Byerly Turk; - by Taffolet Barb; - by Place's White Turk; - Natural Barb Mare. Bred by Lord Jersey.

Tramp got two Derby winners and one winner of The St. Leger. Selim, Sultan's sire, got one Derby winner and two winners of The Oaks. Sultan got two winners of The Oaks and one Derby winner-Bay Middleton. See St. Giles.

Glencoe was much inbred to Herod, Eclipse and Matchem. He was a golden chestnut with both hind legs white half way to the hocks and a large star in his forehead. He belonged to a family of great racers; in 1835 , I9 of SuItan's get won 46 races, the stakes amounting to $\$ 60,89$.

"Glencoe made his first appearance in the Newmarket Craven meeting, 1834, when he won the Tuesday's Riddlesworth stakes of 200 sovs. each, half forfeit, for the produce of mares covered in 1830. - Twelve subs., beating Zulima and two others.

"On the Thursday in the same meeting, he was beaten by Plenipotentiary in a sweepstakes of 100 sovs. each, h. ft. - Nine subs. 
"In the first spring meeting he carried off the Desert stakes of Ioo sovs. each, h. ft. Ten subs. beating Ganges; and the 2000 gs. stakes, beating Flatterer, second, Bentley, third, and four others not placed.

"He ran third for the Epsom Derby stakes, Plenipotentiary being first, and Shilelagh second.

"His next appearance was at Goodwood, where he won the Gold Cup, beating Colwick, Famine, and seven others not placed, Rockingham, St. Giles, and The Saddler among the number. He likewise won at the same meeting, the Racing Sweepstakes of 50 sovs. each, beating Louisa, Defensive, and Rebel.

"His last performance in 1834 , was at the second October meeting, winning the Garden stakes at roo sovs. each. - Five subs. beating Glaucus and Colwick.

"In 1835 he only started once, when he won the Gold Cup at Ascot, beating Bran, Nonsense, Shilelagh, Pussy and four others.

"At the Newmarket second October meeting, Lord Jersey challenged for the Whip, and named Glencoe, but the Challenge was not accepted." 1

Glencoe's fame spread to America and James Jackson "sent an order to England to purchase the best horse in the market and named Plenipotentiary, Priam and Glencoe. . . G Glencoe was purchased at a round sum" said to have been 2,000 guineas - "and made the season of 1836 in England as the property of James Jackson." He more than confirmed the good judgment that induced his selection. Wallace says he "proved to be one of the best horses the world has produced."

Few of Glencoe's sons were ever in the stud. Vandal, one of them, stood many years at Belle Meade and got many winners. But it was through his daughters, mostly, that Glencoe's qualities were fastened upon posterity. Through his daughter, Pocahontas, foaled in England in 1837, and her three great sons, Stockwell, Ratalpan and King Tom, sires of a long list of winners, Glencoe's name was placed so "imperishably upon the scroll of honor"

1 American Turf Register. 
that half a century later it was said that "there is scarcely a good stallion in England today that does not possess a strain of the blood of this great horse"; and in America - "it is safe to say that few or none of the most famous horses now on the turf but have a cross of Glencoe." Among Glencoe's get in this country was Reel who won every race she ran except the last in which she broke down; and who produced Le Compte and War Dance, both bred in Louisiana, the property of Thomas J. Wells. Reel also produced Starke and Prioress. Among Glencoe's many other famous daughters were Fanny King who produced Brown Dick; Nannie Lewis who produced Aldebaran; Topaz who produced Waterloo, Austerlitz, Wagram, Cotton and Lodi; Magnolia who produced Princeton, Skedaddle, Daniel Boone and Kentucky; Rhoda who produced Fleetwing; Novice who produced Norfolk; Nebula who produced Asteroid, Sue Lewis and Asterisk; the dam of Goodwood and the dam of Idlewild. Others, still, of Glencoe's distinguished get were Highlander, Pryor, Frankfort, Peytona and Charmer, the latter the best mare of her day. "As a sire of brood mares no horse native or imported equals him," says Bruce. Among the get of Stockwell, Ratalpan and King Tom were a great many winners of the Derby, the Oaks and the Doncaster St. Leger.

Glencoe stood in Alabama at \$1oo until 1844, but served comparatively few mares besides those of his owner, for reasons previously given. Most of his colts bred by Jackson were sold to Thomas J. Wells and other Southern turfmen. Wells paid Jackson \$6,00o for one half interest in six "young things," the list comprising three sucklings by Glencoe, two 2-year olds or less by Leviathan and one 2-year old by Mango. This was one of many similar sales noted at the time. 
A certain event that took place in Nashville, in 1843 , brought Glencoe into greater favor in Tennessee and in I 844-5-6-8, and, probably, 1847 , he stood at Thomas Flintoff's stable in Nashville at \$50. In I848 Thomas (or James) Kirkman sold Glencoe to W. F. Harper, of Kentucky; he died in that state in 1857 , a few months after his purchase by A. Keene Richards. He was a very nervous, fretful horse and was blind when Kirkman sold him. The statistics of winners previously quoted show that Glencoe was much more liberally patronized in Kentucky than he had been in Tennessee.

Of the 88 principal stallions standing in the United States in 1883, as set forth in Bruce's Turf Guide of that year, 28 were imported. Of the 60 natives, 47 had from I to 6 or more tracings to Sir Archy. Eighteen traced to American Eclipse, and 3 to Leviathan. Of the 28 imported stallions, I3 traced to Glencoe. Of the 60 natives, 35 traced to Glencoe. Among all the thoroughbreds that have been on the American turf since 1820 the author ventures the assertion that more have traced, and with more tracings, to Sir Archy, than to any other horse that has been in America since Diomed.

\section{Devastation of War}

It may take many years to determine the proper rating of a horse. Glencoe, in his day, was noted for the excellent qualities of his get and their ability to run long distances, rather than for an exceeding number of winners. And from the statement just made it would seem, on the surface, that his blood has outlasted Leviathan's. The remarkable number of winning horses got by Leviathan is sufficient to put anyone upon inquiry for some other reason for the difference noted.

Leviathan's get were mostly in Tennessee and farther 


\section{Knee Deep in Clover}

south, whereas Glencoe spent the last eight years of his life in Kentucky, which, throughout the civil war, sat complacent and comparatively unscathed in her neutrality. Although Glencoe stood in Alabama and Tennessee together, twelve years, and in Kentucky nine years, only one of these 35 native-bred descendants of Glencoe was foaled in the South, outside of Kentucky.

With the live stock interests of the South wiped out almost entirely by the demands of two contending armies, for four years, it is not surprising that the names of many horses, celebrated throughout the South, do not occupy a more prominent place in the pedigrees of post-bellum thoroughbreds. The infrequency, or entire absence, of the names of many of them, indicates that they are unknown to this generation by reason of the devastation of war. ${ }^{1}$

\section{Other Distinguished Sires}

Other distinguished horses of this decade were:

Post Boy: See "Post Boy vs. John Bascombe," post. Picton, b. by imp Luzborough, dam Isabella by Sir Archy. Isabella's dam was Black Ghost by imp Oscar; - Pill Box, by imp Pantaloon by King Herod. Pantaloon's dam was Nutcracker, by Matchem. Up to Nov., I837, Isabella's produce had earned $\$ 75,000$, and a $\$ 10,000$ offer for Picton had been refused. Bred by Col. Wm. Wynn, of Virginia; season I839 at L. P. Cheatham's, Nashville; \$1 oo. See "The Leviathans vs. The Luzboroughs," this volume, post.

${ }^{1}$ The destruction wrought by "the" war on the habits and industries of the Southern people is strongly reflected, also, by contrasting the facts now to be stated with the figures given on the same subject in Chapter I. Of the entire 88 thoroughbred stallions in 1883, two were in Virginia, three in Maryland, one in Alabama, one in Texas and eleven in Tennessee, those in Tennessee being in Sumner and Davidson Counties. Of the 60 native stallions in I883, eight were bred in the South outside of Kentucky. Of these eight, two were bred in Virginia, five in Tennessee and one in Texas. 


\section{Making the American Thorougbbred}

Ainderby, imp ch.; by Velocipede, dam by Catton. Foaled 1832. M E. Imported by Lucius J. Polk, Mt. Pleasant, Dec., I838; \$75; \$100. As a 3-year old Ainderby, carrying I 8 Ibs., ran in the then unprecedented time (for 3-year olds) of $1: 43$. Polk paid a "high figure" for him. Velocipede sired more winning horses than any stallion of his day. One of his get, Queen of Trumps, won The Oaks in 1835 and the St. Leger in the same year, and another, Amato, won The Derby in 1838. Catton got one Derby winner.

Anvil, br. foaled 1829; by Mons. Tonson, dam Isabella by Sir Archy. Bred by Col. Wm. Wynn of Virginia. Won three out of four sweepstakes. Later purchased by Balie Peyton for $\$ 6$, ooo from James B. Kendall of Maryland; \$50; \$75.

ArAB, foaled 1820; by Sir Archy, dam Bet Bounce by imp Sir Harry by Sir Peter Teazle. Bred by J. J. Harrison of Virginia. Rev. H. M. Cryer's, Sumner County; \$35; \$50. Arab, valued at $\$ 8,000$. From 1833 to 1838 , inclusive, Arab's, get won 52 races. Autocrat, imp gr. I6 $\frac{1}{2}$ hands high, foaled 1822; by Grand Duke, dam Olivetta by Sir Oliver; - Scotina by Delpini; - Scota by Eclipse; - by Herod. Delpini sired two winners of The Oaks and one St. Leger winner. Autocrat, bred by Lord Derby, won many races in England. As property of Tayloe \& Tayloe, of Virginia, stood 1836 at Thomas Barry's, \$50; $\$ 60$; in 1837 at R. C. Dickinson's, Montgomery County; sold to Col. Samuel Lyne, of Montgomery County, in 1839. Autocrat had 37 traces of the Darley Arabian, 25 of the Godolphin, 2 I of Flying Childers, 13 of Bartlett's Childers, 14 of Regulus, 7 of Herod and 5 of O'Kelly's Eclipse. He was in the male line from Herod and had blood of Diomed. Elis, who won the Doncaster St. Leger in 1836, was something like a half-brother to Autocrat.

BeнEмотн (Hamlet), br. foaled i 824; by Bagdad, dam Rosey Clack. Bred by Rev. Hubbard Saunders. Owned by W. E. Broadnax, Virginia; 183 I at A. B. Newsom's; 1836 at A. G. Ward's one mile north of Clover Bottom.

Belshazzar, imp ch. foaled 1830; by Blacklock, dam Manuella (winner of The Oaks in 1812) by Dick Andrews. Bred by Richard Watt. As a 2-year old Belshazzar won races at York and Doncaster. He won the Gascoigne stakes, 5 subs. 100 sovs. each, after which Watt refused 5,000 guineas for him. After a victory at Newmarket in 1834 he broke down and was placed in the stud. Imported in 1838 by Thomas Flintoff or Thomas Alderson \& Co., 


\section{Knee Deep in Clover}

and stood in Nashville; \$75; \$100. H E. The dam and grandam of Belshazzar produced winners of 99 races, 19 of which were of four miles. Manuella produced Memnon, a Doncaster St. Leger winner. Manuella's sister also won the St. Leger. Theodore, out of Blacklock's dam, won the St. Leger.

Carolinian, b. foaled 1815; by Sir Archy, dam by imp Druid, whose dam was by Herod. Bred by Phil Claiborne of Virginia or North Carolina; 1830 at Edwin Smith's, Davidson County. Advertised by Thomas Claiborne to stand 1831 , in charge of $\mathrm{P}$. W. Long at Nashville race track. Carolinian ran eight races and won seven.

Crusader, b. foaled i 823; by Sir Archy, dam Lottery by Bedford. Lottery's dam imp Anvilina. Bred by Colonel Singleton, of South Carolina, 1833 and other years at Rev. H. M. Cryer's. Of eighteen entries in a 2-mile race arranged in 1830 at Columbia, South Carolina, fourteen were by Crusader. Of eighteen entries, produce of $183 \mathrm{I}$, in a race to be run in 1835 , eleven were by Crusader. He beat the renowned Ariel, by American Eclipse, several times. His stride is raid to have been twenty-five feet. See Appendix.

Fop, imp gr. foaled 1832; got by Stumps by Whalebone, dam by Fitz James. H E. Imported by Lucius J. Polk; \$50; \$75. See Whale and Lap Dog. In I843 Fop was purchased by W. G. Harding for $\$ 2,000$.

Giles Scroggins, b. foaled 1824 or 1828; by Sir Archy, dam Lady Bedford by imp Bedford, g. dam by imp Dare Devil. Bred by James Jeffries or W. B. Moses, Caswell Co., North Carolina; 1836 at W. B. Gowen's, 6 miles from Nashville, on Murfreesboro road. Two seasons previous at Wm. Pillow's, Maury County.

MARGRAve, imp ch. foaled 1829; by Muley, dam by Election who won The Derby in 1807 ; g. dam by Hambletonian who won the Doncaster St. Leger in 1795. Election's son Gustavus won The Derby in 1821. Margrave bred by Mr. Dilly. Won the Doncaster St. Leger in 1832, 73 subscribers; the Criterion stakes, 36 subscribers; the Grand Duke Michael stakes, 15 subscribers; the Gascoigne stakes, II subscribers and other races. Imported into Virginia by Merritt \& Merritt, 1835; 1837 at Thomas Alderson's stable, Nashville; \$75; \$roo. See Leviathan.

O'Kelly, gr. foaled I827; by American Eclipse, dam Young Empress (the dam of Ariel) by Financier. Bred by John C. Stevens, Flat Bush, Long Island and i 4 Barclay Street, New York. In a 4-mile heat race over the Union Course, Long Island, in I833, O'Kelly 


\section{Making the American Thorougbbred}

beat Tobacconist and three other competitors; time 8:02 - 8:01 - 8:08. In 1835 O'Kelly stood at Alderson's stable, Nashville, and Iater stood several seasons in Williamson County - at A. T. Nolen's, Ennis Murray's and A. Rodgers'. Service $\$ 40 ; \$ 75$. Valued at $\$ 8,000$.

PACIFIC - "The Great Pacific" - b.; by Sir Archy, dam Eliza (full sister of Gallatin best son of imp Bedford), out of imp Mambrina by Mambrino. Pacific full brother of Bertrand. Bred by John R. Spann of South Carolina. Owned by Duke W. Sumner; kept many years at his farm, Spring Grove, 7 miles north of Nashville, adjoining the Phillips farm. Service $\$ 30$. Pacific got many winners of races and several stallions of note. In $1837-38$ his get won 30 times. Sumner sold to Henry A. Tayloe of Macon, Alabama, (formerly of Mt. Airy, Virginia) two 2-year old Pacifics for $\$ 3,500$. Another of his colts sold to Mobile for $\$ 1,000$. These were not exceptional sales; but Bertrand's get brought more money than Pacific's.

Philip, imp br. foaled 1828; by Philo da Puta, dam Treasure by Camillus. н м. Philo da Puta won the Doncaster St. Leger in 1815 and his son Birmingham won it in 1830 . Imported by Tennessee company, in February, 1838 , and stood that season at Franklin; 1839 at Rev. Hardy M. Cryer's; \$75; \$125. In EngIand Philip ran in 40 races, won 23 and was several times second. RAtLer (or Rattler) (Thornton's), foaled 1816; by Sir Archy, dam by imp Robin Redbreast, g. dam by imp Obscurity. Robin Redbreast was by Sir Peter Teazle; his dam, Wren, was by Woodpecker. Ratler was bred in Maryland. He ran 25 races and won 20, 18 of which were of 2 miles or more. Owned by Balie Peyton; stood at John H. Robinsons', Murfreesboro, and at G. W. Parker's, Sumner County; sold to Maurice E. Boyles (or Broyles), La Grange, Tennessee. Service \$40; \$6o. As a sire Ratler had a fine reputation. Of sales reported by Balie Peyton was a Ratler colt to Mississippi for \$2,000.

SHAKESPEARE, imp foaled 1823 ; by Smolensko, dam Charming Molly by Rubens; g. dam by Beningbrough. Shakespeare ran second to Lap Dog in a field of 19 contestants when Lap Dog won The Derby in 1826 . He won 8 of 9 races run. Imported into Virginia by Merritt \& Co., I 835; stood at Rev. Robert Hurt's, Paris. See Leviathan. Among the nominations for The Derby of 1837 were three colts by Shakespeare; for The Oaks one filly by him. Smolensko won The Derby in 1813 and got one winner of The Oaks 


\section{Knee Deep in Clover}

and one winner of the Doncaster St Leger. Smolensko belonged to the Matchem family, being a son of Sorcerer, son of Trumpator. Sir Richard Tonson, gr. foaled i823; by Pacolet; dam Madam Tonson; 1829 at Thomas Foxhall's, Sumner County; I831 at P. J. Burrus', Murfreesboro.

Sir Henry Tonson, foaled i 824; full brother to Sir Richard Tonson; I 829 at Rev. H. M. Cryer's. In January, I 831, purchased by Jo C. Guild and Thomas Barry, brought back from North Carolina and stood at "Barrymore." Died at Portsmouth, Virginia, September, 1836 , as property of Balie Peyton.

SKYLARK, imp, foaled 1826; by Waxy Pope (of the Whalebone family), dam by Musician, etc. H. Bred by Mr. Daxon. Winner of 42 races, 24 of them King's plates. Imported into Virginia by Dr. Merritt, 1836; stood at L. P. Cheatham's. Service \$1oo; \$125. It required a four column advertisement for Cheatham to tell of Skylark's pedigree, performances and progeny.

Whale, imp b. foaled 1830; by Whalebone, dam Rectory by Octavius winner of The Derby in 1812 . H E. Direct male line from Pot8os. Imported into North Carolina by Edward Townes, 1835. Under control of Rev. Robert Hurt and John Hurt, stood at McLemoresville, Carroll County; \$6o. See Lap Dog.

Wild Bill (formerly Pilot), foaled I827; by Sir Archy, dam by Gallatin. Season 1837 at George W. Garrett's, on Bradshaw's Creek, Giles County; \$50; \$75. As Mr. Cheatham's entry Wild Bill ran in Tennessee in 1831 . At the Nashville fall meeting of that year he beat five competitors the first three heats in a mile race "best 3 in 5"; time $1: 52-1: 52-1: 50$. He got many winners. One of his sons, Gander (dam Grey Goose by Pacolet), was sold by Capt. John Connolly to R. H. Long, of Columbus, Mississippi, for $\$$ ro,ooo.

\section{Other Good Stallions}

Other good stallions of this decade were as follows:

Bolivar, gr. owned by Gen. Andrew Jackson and advertised by him to stand at the Hermitage; \$20. In his advertisement Jackson says: "Bolivar was gotten by Oscar out of a mare by Pacolet; she out of a mare by my favorite horse Truxton by Diomed; and she out of the Opossum filly by Wildair or Melzar. Opossum filly a first rate four-mile runner." Advertisement con- 


\section{8}

tains statement signed "Jesse Haynie" to the effect that he had trained Bolivar; qualities given. See Appendix.

The O'Possum filly, about 1807 , was purchased by James Jackson from SamueI Pryor, of Kentucky, for $\$ 400$ and placed with Gen. Andrew Jackson to breed on shares. She produced two mares by Truxton, which Gen. Jackson kept as brood mares. The O'Possum filly was a grey, by imp Medley, dam by imp Highflyer by Highflyer.

Cock OF THE Rock, foaled I8I4, half brother to American Eclipse; his dam Romp by Messenger. Bred by Nathaniel Coles. Ran successfully in the East. Season 1835 at Thomas Barry's. Service \$6o. In 1836, 1837 Cock stood at W. R. Brown's, Giles County. In 1838 , Barry and Maj. David Burford, of Dixon Springs, sold him to John McGhee, of Knoxville, for $\$ 2,500$. Barry sold two Cock of the Rocks to Governor Anderson, of Illinois, for $\$ 1,000$.

Contention, deep sorrel foaled 1815; by Sir Archy, dam a Dare Devil mare, owned by Mr. Irby of Virginia; 1831 at Henry Cook's, Sr., Franklin; \$25.

JEFFERSON, br. foaled I825; by Virginian, dam by Bellair by imp Medley. Bred by J. J. Harrison of Virginia (Wallace says Francis Thornton, North Carolina), stood in Poughkeepsie, New York, in 1831; in 1835-1837 at W. L. Alexander's near Hartsville; 1832 at Thomas Barry's. Alexander sold to Arkansas a mare by Jefferson, dam by Sir Henry Tonson, for $\$ 1,500$, and four Jefferson colts for $\$ 4,000$.

Jerry, dap. gr. foaled 1825; by Pacolet, dam Black Sophia. Bred and owned by Col. George Elliott; 1831 at Hugh Long's, Giles County, where he stood three seasons. Won seven of ten races run. John Dawson, b. foaled 1830; by Pacifrc. In advertising Dawson for season 1836 at his place Cotton says Dawson's dam was by Barry's Grey Medley, g. dam by Pacolet, g. g. grandam by Gen. Jackson's Truxton; 1825 at Arthur Cotton's, Sumner County; I839 at Francis Gordon's, Spring Hill, Maury County; $\$ 50$.

LAP Dog, imp b. foaled 1823; by Whalebone, dam by Canopus. H E. Bred by Lord Egremont. Pot8os, son of O'Kelly's Eclipse, got one St. Leger winner, one winner of The Oaks and two Derby winners, one of whom was Waxy who won The Derby and got four Derby winners and three winners of The Oaks. The four Derby winners were Pope, Whalebone, Blucher and Whisker. Whalebone got one winner of The Oaks and two or three Derby winners, one of whom was Lap Dog, the winner in 1826. Lap Dog imported by James Jackson, Alabama, in 1835; stood 1836 at 


\section{Knee Deep in Clover}

Thomas AIderson's stable, Nashville; \$50; 1837 at George Elliott's; 1838 in Lincoln County.

Mambrino, dk. ch. foaled 1827; by American Eclipse, dam John Randolph's Grand Dutchess by Gracchus. Bred by Gen. C. Irvin of Philadelphia. A. J. Donelson purchased one half interest in 1835 and kept him several seasons at his farm near the Hermitage. $\$ 40 ; \$ 50$.

Marshal NeY, foaled 1824; by Pacolet, dam Virginia by imp Dare Devil. н M. Rev. Hardy M. Cryer's.

Merman, imp br. foaled 1826; by Whalebone dam by Orville. Imported by Dr. Merritt of Virginia; 1836, 1837 at L. P. Cheatham's; 1838 at Alex Black's, McMinnville. \$60; \$10o. See LAP Dog and Leviathan.

\section{Still Other Good Ones}

Still other successful stallions of this decade were:

Andrew Jackson, by Virginian, dam by Sir Arthur; Giles County. Bellair, by Sir Archy, dam Favorite by Bellair, g. dam by imp Bedford; owned by Robert H. Peyton; stood at Jackson.

Chesterfield, by Pacific, dam Roxana; A. T. Nolen's, near Franklin; $\$ 30$.

Citizen, by Stockholder, dam Patty Puff by Pacolet; Giles County. Coronet, imp b. by Catton, dam by Paynator. Imported in 1837 by Dr. Merritt of Virginia. Stood at Edward Hoskins near Somerville, \$6o; \$roo. See Ainderby. Coronet won about 30 races.

Count Badger, ch. foaled 1826; by American Eclipse, dam by Hickory. W. T. Sperrill's, Lincoln County.

Cramp, by Arab, dam by Sir Archy; Giles County.

Flint, by Stockholder, dam Sting by Conqueror; Jesse L. Flippin's, near Somerville.

Frozenhead, by Crusher, dam by Sir Archy. Crusher's dam by imp Sir Harry. A. B. Newsom's.

Gaston, by imp Truffle, dam Lady La Grange by Sir Archy. Col. Joseph H. Townes, Dresden.

Glenroy, by Editor, dam by Sir HaI; D. D. McFalls, near Columbia.

Gold Boy, by Industry, dam by Oscar; Jesse Luton's near Pulaski. GrEy ARchy, by Sir Archy, dam by Grey Medley, foaled I8II. 


\section{$90 \quad$ Making the American Thorougbbred}

Bred by Benjamin Phillips of Davidson County. Owned in 1830 by Duke W. Sumner.

Gun Powder, by American Eclipse, dam Gazelle by Sir Archy. At William Dickinson's, Cornersville, and Thomas Alderson's, Nashville.

Havoc, ch., by Sir Charles, dam Powancy by Sir Alfred by imp Sir Harry. Bred by W. R. Johnson of Virginia. Sold to Rev. H. M. Cryer for $\$ 2,500$. Stood at his place in Sumner, at Ledbetter \& Clark's, Murfreesboro, and at Hal Cook's, Franklin. Name changed to Sir Charles Pinckney; as such stood at Rev. Martin Clark's, near Murfreesboro, in 1831 .

Hephestion, by imp Buzzard, foaled 1807; died in Tennessee in 1833. Owned originally by Col. John Tayloe, of Virginia. Buzzard was by Woodpecker; was imported into Virginia and died in Kentucky in 1811 , aged 24. Quiz, by Buzzard, won the Doncaster St. Leger in 1801 .

Highlander, foaled 1828; by American Eclipse, dam by Duroc. Bred in Pennsylvania. Stood at Memphis Race Course.

HUGH LAWSON WHITE, foaled I 833; by Leviathan dam by Conqueror. Owned by Gen. J. A. Mabry of Knoxville. After Mabry's death in 1837 purchased by a Sparta company for $\$ 6,410$. Stood at Samuel V. Carricks, Sparta; $\$ 60 ;$ \$ $о$ oo. Celebrated racer.

La FAyette, by Conqueror, dam Julia by Sir Arthur. Stood at Hollon Davis' and at L. B. Beech's, Williamson County.

Leviathan, JR., by imp Leviathan, dam by Napoleon. F. S. Heiskell's, Sinking Creek, near Knoxville.

LuRCHER, imp foaled 1832; by Grey Leg, dam Harpalyce by Gohanna sire of Election. Bred by Lord Egremont. Selected for importation by Allen J. Davie of North Carolina. Stood at Col. Samuel Bunch's, Grainger County; $\$ 50 ; \$ 75$.

Macedonian, by Roanoke, dam Statira by Alexander the Great. Bred by John Randolph of Roanoke; 1834 at Nashville race track.

Melli Melli, by Virginian, dam by Sir Archy; 1836 at W. H. Edwards', Fayette County.

Mercury, by Sir Archy, dam by Sir Archy; 1832 at H. S. Wilkinson's, Murfreesboro.

MondecaI, imp foaled 1833; by Lottery, dam by Welbeck. Sold by Thomas Flintoff, of Franklin, to Henry Baldwin, Jr., of same place in the Iatter '3o's. Fine horse. Lottery got one winner of the Doncaster St. Leger. 
Orphan Boy, by American Eclipse, dam Maid of The Oaks; 1834 "in Tennessee."

Partnership, by Volunteer (by Gallatin), dam Rosey Clack; I832 at farm of W. R. Saunders, son of Rev. Hubbard Saunders, near Saundersville.

PrIAM, by imp Leviathan, dam by Sir Archy. Wm. McMahon's, near Memphis, \$35; \$50.

RoBin Hood, ch. foaled I828; by Henry, dam by Hickory and he by imp Whip. Bred by Nelson Lloyd of Long Island; 1838 at Jesse Luton's near Pulaski; \$40; \$6o. Up to the race in which he broke down he won nine, Iost two and paid forfeit once.

Romulus, by Pacolet, dam by Sir Archy, out of a fine Bedford mare from North Carolina; S. Cantrell's, Charlotte road, Davidson County.

Robin Adair, by Sir Archy, dam Lady Burton, by Sir Archy. Bred by John Randolph, of Roanoke; Marshall and Bedford Counties. SaXe Weimer, b. foaled 1822; by Sir Archy, dam Lottery by imp Bedford. H E. See Crusader. Bred by Col. William Alston of South Carolina. Stood at Rev. H. M. Cryer's several years; at Samuel Mitchell's, Shelbyville, in 1835 .

Sir ANDREw, by Bagdad, out of Lady Deaderick. Thomas Martin's, Davidson County.

SkYLARK (called a hunter), b. foaled 1824, by imp Exile; bred by Philip Wallace, Maryland; owned in 1832 by Rev. H. M. Cryer. St. GiLEs, imp foaled 1829; by Tramp, dam Ascot Lass by Androssan. н м. Bred by Mr. Risdale; won The Derby in 1832 . His half-brother Scroggins ran second in a field of 14 contestants in The St. Leger in 1836 ; another brother (half or full), Bloomsbury, won The Derby in I839, defeating 20 contestants. John Bull, sire of Androssan, won The Derby in 1792; John Bull's dam was Fortitude by Herod. St. Giles imported in 1835 by James Jackson; in 1836 stood at George Elliott's; \$6o. See Glencoe.

Talleyrand, by Kosciusco, dam Kitty Fisher by Financier; Jesse Luton's; \$3o; \$40.

Telegraph, b. foaled 1828; by Stockholder, dam Caroline by Volunteer. Bred by Rev. Hardy M. Cryer, but raised in "Western District;” (John) Barfield, Caldwell \& Co., Paris; \$50; \$75.

Toвacconist, a Virginia horse, foaled I829; got by Gohanna; dam Yankee Maid by Ball's Florizel; Rev. H. M. Cryer's. Fine racer. Traveller, by Arab, dam by Conqueror; Maj. Wm. Ainsworth's, Madisonville, Monroe County. 


\section{2 Making the American Thoroughbred}

Wacousta, ch. foaled 1832; by imp Leviathan, dam Lady Lightfoot by Oscar. Bred by Hugh Kirkman. Stood at H. and J. Kirkman's, near Nashville; and at Thomas T. Bullock's, Middletown, Rutherford County. Wallace says this horse was "the property of W. Williams of Tennessse."

Walton (or Walter), by Eclipse, dam by Constitution; Liles E. Abernathy's, near Pulaski.

Young Virginian, by Virginian. R. H. Wallace's, on Murfreesboro road.

Young Sir Charles, by Sir Charles, dam by Ball's Florizel; at Abner Stacy's, Spring Hill, Maury County.

ZAMOR, by Silver Heels (by Ogle's Oscar), dam Aurora by Vingt'un, was bred in Maryland and purchased in Pennsylvania by a Tennessee company that placed him in charge of Gen. Robert Desha, at Gallatin, in 1832 . Vingt'un was by imp Diomed, dam by imp Clockfast.

Judge Williams said that "Swiss" stood at Duke W. Sumners in 1835. Imp Swiss was foa ed 1821; by Whisker. He was "first favorite" for the St. Leger in $1824 .{ }^{1}$

\section{Mares Imported}

By L. J. and R. K. Polk: Vaga, Venetia, Tunica, Stumps Mare, Primrose, Sweetbriar, Pledge, Panola, Jennie Mills, The Colonel's Daughter (Adela), Variella, Varialetta. The Colonel won the Doncaster St. Leger in 1828. R. K. Polk owned, also, imp Refugee and imp Tomboy Mare.

By H. and J. Kirkman: Florestine; Myrtle, by Mameluke who won The Derby in 1827 and ran second in the Doncaster St. Leger the same year; Mango, Nannie Kilham, and Equity. Florestine, Nannie Kilham and Equity were sold to W. G. Harding.

By Thomas Alderson: Black Bess, by Belzoni brother to Belshazzar.

By J. C. Beasley: Rebecca.

By Thomas Flintoff: Kill Devil by Belzoni, and Fortuna, by Langar sire of Elis.

Among importations into other states, known to have come to Tennessee were: Vamp by Langar; Nun's Daughter by Filo da Puta; Phantomnia, Anna Maria, Likeness, Blacklock mare and Chance mare.

.1 For list of stallions extended into the 1840 's, see Addenda F. 


\section{Imported Horses of Later Period}

The following named imported stallions, not previously mentioned, stood in Tennessee after 1840 ; the names only being given by Killebrew; other facts from other sources: Ambassador, by Emilius; imported by Col. Wade Hampton. Scythian, and Sacklowie (an Arabian); imported into Kentucky. Rowton, winner of the Doncaster St. Leger in 1829; imported into Virginia. Teneriffe and Emu; both imported by Thomas Flintoff. Espersykes, by imp Belshazzar; imported by Thomas Alderson. Volney, by Velocipede; Shamrock by St. Patrick; and Albion by Cain or Actaeon.

\section{Straight Down the Line $^{1}$}

The way in which the "live lines" came down and penetrated the Tennessee stock is shown by these instances of descent through sire and son. As a rule the dams of the horses belonged to a line different from that of the sires.

Matchem Line - (I) Matchem, Conductor, Trumpator, Sorcerer (who got three winners of The Oaks), Smolensko, imp Shakespeare.

(2) Sorcerer, Comus, Berner's Comus of North Alabama.

EcLipse Line - O'Kelly's Eclipse, King Fergus, Beningbrough, Orville, Muley, sire of Leviathan and Margrave.

Herod Line - (I) Herod, Florizel, Diomed, Duroc, American Eclipse, O'Kelly and others.

(2) Diomed, Sir Archy, Timoleon, Boston, Lexington.

1 For additional facts about performances and offspring of English horses mentioned under this sub-head, and elsewhere in this chapter, see Addenda B. 
94 Making the American Thorougbbred

(3) Herod, Highflyer, Sir Peter Teazle, Williamson's Ditto, Luzborough, Picton.

(4) Herod, Woodpecker, Buzzard, Selim, Sultan, Glencoe, Vandal, Virgil, Hindoo, Hanover, The Commoner, and Great Britain whose likeness is presented as illustrating the continuation of the line to the present time.

Tremont, the sire of Great Britain's dam, Touch Not, was by Virgil. The Commoner, besides having many crosses of Glencoe, traced to Lexington, Woodpecker (by Bertrand) imp Medley, Virginian, Ball's Florizel, and many other horses named in these pages.

Touch Not, besides having many crosses of Glencoe, numbered among her ancestors Lexington, Stockholder, Pacolet, NeII Saunders, Wilkes' Wonder, and many other horses previously mentioned.

Among Great Britain's achievements these are noted in an advertisement printed by his present owner Mr. Geo. M. Hendrie:

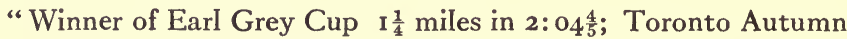
Cup; Derby Cup, $1 \frac{3}{4}$ miles in 3: $0 \frac{8}{5}$, Canadian record; Toronto $\mathrm{Au}$ tumn Cup; Ontario Jockey Club Cup, $2 \frac{1}{4}$ miles in 3:54 $\frac{3}{5}$, Canadian Record; Louisville Cup; a mile in $\mathrm{r}: 37 \frac{2}{5}$."

All in all he has won 16 races, has run second in 6, third in 3 and has been unplaced twice. Great Britain's trainer is John Walters, of Nashville.

The number of celebrated stallions that stood in the various sections of Tennessee prior to 1840 is a fair index to the large number of planters, merchants, Iawyers, doctors, preachers and what not, who bred race horses "on the side." In this respect the breeding business was more profitable than it was after the Civil War, when it centred in a few large establishments.

Before 1840 the average price for a suckling or yearling seems to have been about $\$ 1,000$; for a promising indi- 
vidual between one and three years old about \$2,000; the get of Leviathan, Glencoe and Bertrand averaging higher than other stock of the same period.

Of the 88 celebrated stallions in I 883 only one - King Ban - stood as high as $\$ 150$. Only 15 others stood as high as $\$$ roo. Most all the others at $\$ 50$. Some as low as $\$ 25$. Forty-two Belle Meade yearlings sold in 1883 for an average of $\$ 652.85$ - Great Tom's get averaging $\$ 400$, Enquirer's, $\$ 867.25$. Only 13 were sold to Tennessee and states south of it. 


\section{Chapter VI \\ SUMNER COUNTY, BREEDING CENTRE}

Sumner County, established I786, antedating the State of Tennessee by ten years, lies between the Kentucky line and the Cumberland River. It is at the head of the great Middle basin which extends through the state to the Alabama line. A dozen or more counties comprise the central area of this basin, among them being, besides Sumner, Davidson, Montgomery, Williamson, Rutherford, Maury, Giles, Bedford, MarshaII and LincoIn. The soil of this basin is ingrained with limestone and - as has been learned in recent years - with phosphate. It is abundantly watered. Its adaptability to animal life was made known to the Indians by the great number of buffalo and deer always found here; and by agreement of various tribes this basin was held in common for use as a hunting ground. It was, therefore, in the logical course of events that the farmers of this rich basin should avail themselves of the opportunities which nature had placed at their door, and become the supply depot for the horse and mule market of other states. ${ }^{1}$

The leading county in this industry was Sumner; and in Sumner the breeding business centred on east Station Camp Creek, which flows from the highlands in the north to Cumberland River, passing about two miles west of Gallatin. This creek is crossed by three roads

1 See Addenda G. 


\section{Sumner County, Breeding Centre}

that run west or northwest from Gallatin. Where the Nashville road - the one nearest the river-crosses the creek, lived Dr. Redmond Dillon Barry. Where the Long Hollow road - next on the north - crosses the creek lived James Cryer. Farther up the creek, where it is crossed by the Red River road, lies the farm long owned by Col. George Elliott. About four miles to the west of the Barry home, on the Nashville road, resided Rev. Hubbard Saunders. Orville Shelby lived "one half mile southwest of Gallatin" - probably at Spencer's Choice. These were the men who Iaid the foundation for Sumner County's reputation among horsemen of the entire Union - a reputation acquired as early as 1829 and maintained to within recent years.

A few words about these men before showing the immediate results of their labors as breeders.

Dr. Barry was a native of Ireland, a schoolmate and friend of Gen. Packenham at Dublin University. Through the influence of Charles James Fox he secured a position as surgeon in the British navy, but his sympathies being with the colonies, he resigned, settled in North Carolina, practiced medicine and made a fortune. He then studied law in the office of John Breckenridge (AttorneyGeneral in Jefferson's Cabinet) in Louisville, removed to Gallatin, married Jane Alexander of the Mecklenburg (North Carolina) Alexanders, and became a successful lawyer. He was a warm friend of General Jackson.

The history of the grazing sections of Kentucky and Tennessee show such a close connection between blue blood and blue grass, it is worthy of mention that Dr. Barry, who brought Grey Medley into Middle Tennessee, also introduced blue grass; he blazed the way for the greatest agricultural specialty the Middle basin has ever had - the breeding of thoroughbred horses. By this 


\section{$98 \quad$ Making the American Thoroughbred}

specialty has Tennessee been best known ever since she stopped producing presidents.

James Cryer was a Revolutionary soldier and came to Sumner County from North Carolina. He was a wealthy and influential citizen and represented Sumner County in the legislature of 1815 . On the farm he owned may still be seen the marks of a track which is said to have been the first in Middle Tennessee where public race meetings were held, antedating Clover Bottom by many years. A few hundred yards away is the site of the old log court house, where Andrew Jackson had his famous fight with the Kuykendalls. It is tradition, firmly believed in this locality, that when Jackson was here attending Court as Attorney-General he rode in races on this track. The only way to undermine this tradition would be to prove that races were not run on this track when Jackson was here as Attorney-General.

Cryer died in 1816. Madam Tonson was his chief contribution to Sumner's foundation stock.

Col. George Elliott, born in North Carolina in $178 \mathrm{r}$, was a colonel under Gen. John Coffee in the Creek war, and at the battle of New Orleans. By his efficient military service he won the friendship of Gen. Jackson. Jackson offered him command of the troops in the Florida war, but Elliott thought he had done his share of fighting and declined.

Col. Elliott commenced his career as a breeder and turfman, prior to 1813 , and continued until about the time of his death, in 186r. "Wall Spring" was the name of his farm and the residence built by him in 1828 still stands. In a flat across the road from his house Elliott had a splendid race track where many a "nag," afterward famous, joined the infant class in daily exercise. His home was a gathering place for people from all sections 


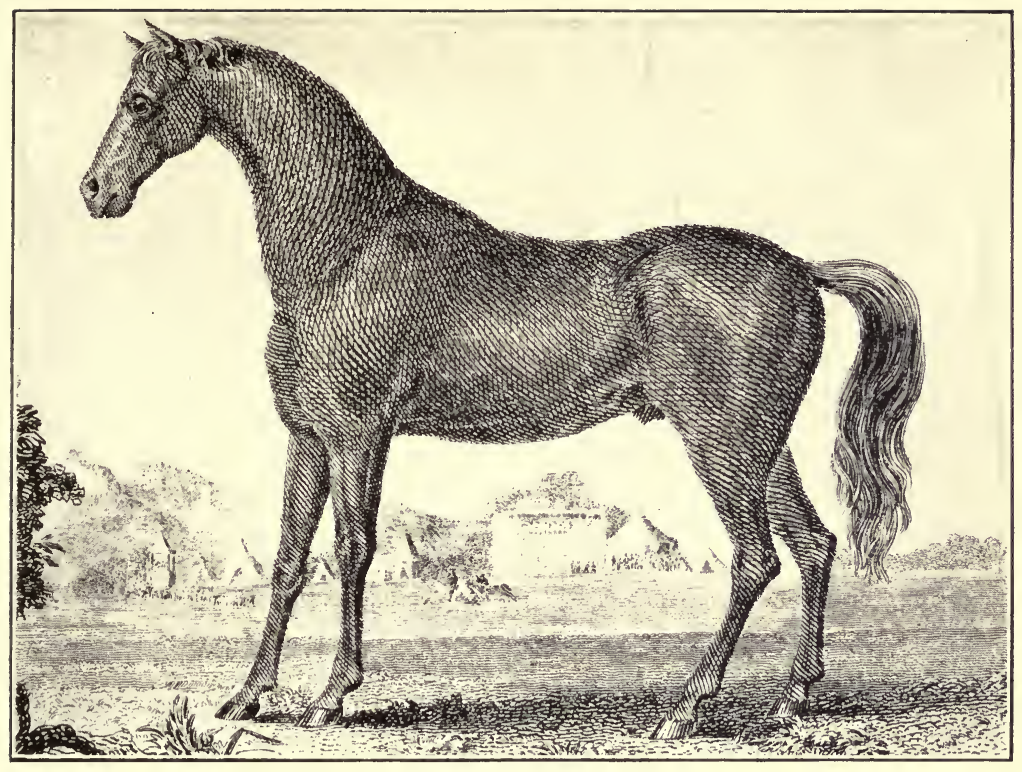

IMP DIOMED

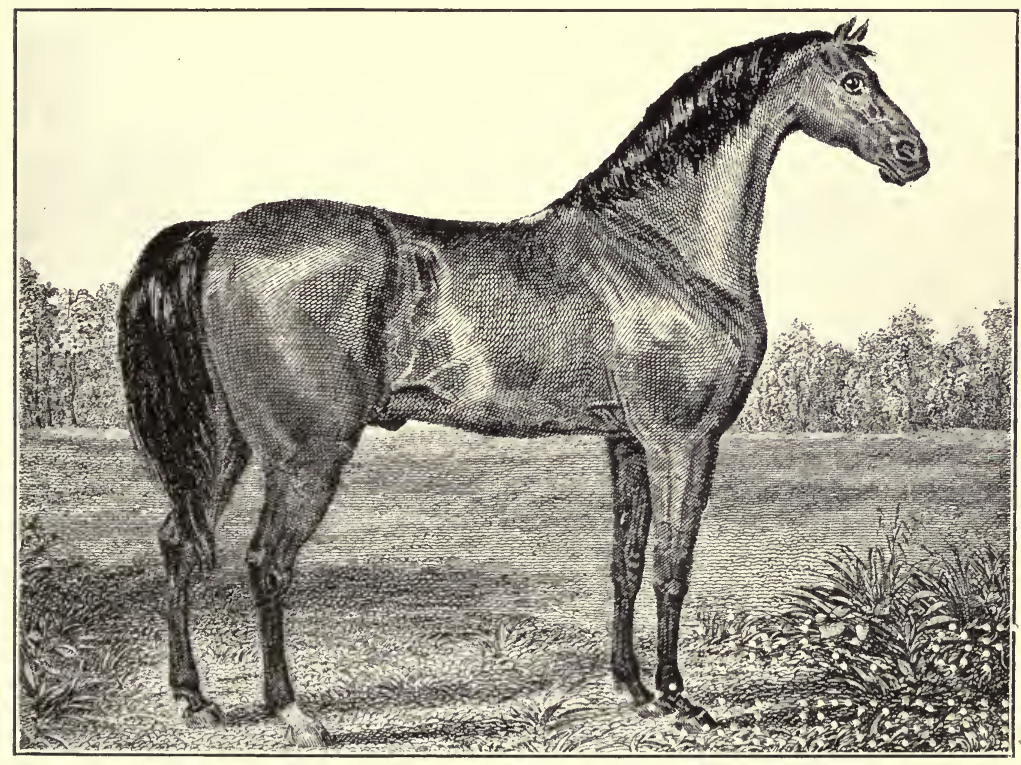

Sir Archy 



\section{Sumner County, Breeding Centre}

of the country and every meal was prepared for "company." Elliott accumulated a fortune. His success bespoke for him a genius for his calling - tact, sound judgment and fine capacity for detail. All his contemporaries conceded to him first place among Tennessee breeders and turfmen. Top Gallant, Pacolet, Napoleon and Leviathan, in the order named, were Elliott's chief contributions to Sumner's foundation stock prior to 1840 , in the male line; in the female line only Black Sophia need be mentioned.

Rev. Hubbard Saunders came from Virginia to Sumner County in 1798 and settled one mile west of the present site of Saundersville. McFerrin's "Methodism in Tennessee" says that Mr. Saunders "lived to an advanced age laboring all the time as a local preacher," and "maintained a fine reputation as a citizen and minister." On his land was erected a church - the progenitor of the present Saunders Chapel - and an encampment where, for many years, the Methodists held camp meetings. "These annual convocations," says McFerrin, "were great blessings and were the nurseries of Methodism in Sumner County." Mr. Saunders' farm was also the nursery of some fine race horses. His main contributions to Sumner County's foundation stock were Wilkes' Wonder, Rosey Clack and Tennessee Oscar. Mr. Saunders died in 1829, possessed of numerous slaves, several race horses, many thousands of acres of land in various sections of the country and thirteen children; to each of those living at his death he willed \$30 to buy "mourning" to wear after his demise.

Orville Shelby, a son of David Shelby and grandson of Anthony Bledsoe, was born in Sumner County. He married, for his second wife, a daughter of Gen. James Winchester and moved to Kentucky about I830. General Jo Shelby, of Shelby's Brigade C.S.A., was Orville 


\section{Ioo Making the American Thorougbbred}

Shelby's son by his first wife. As previously shown, Orville Shelby introduced Stockholder into Tennessee.

\section{Three Mares and Their Produce}

Rosey Clack was bred in Virginia by W. E. Broadnax of Brunswick County, or by John Clack. Her sire was imp Saltram. Her dam was either Camilla by Melzar or Camilla by Symmes' Wildair - both Camillas being owned by Broadnax. Balie Peyton said her dam was the Camilla by Wildair, and in his Reminiscences, No. 8, gives her pedigree extended; which see.

Rosey Clack was brought to Tennessee by Rev. Hubbard Saunders about 1812 or 1813 , and he owned her and bred from her until her death in 1827 . Of her thirteen foals were Oscar by Wilkes' Wonder, I8I4; Partnership by Cotton's Volunteer, I82I; Patty Puff by Pacolet, I823; and Washington by Pacolet, I824.

Madam Tonson, by Elliott's Top Gallant, was foaled I8I4, dam by Dr. Barry's Grey Medley; grandam by imp Oscar; g. grandam by imp Fearnought. Wallace says: "This was one of the most distinguished brood mares this country has produced. She was owned by the Rev. Hardy M. Cryer of Tennessee. Died I831."

Madam Tonson's dam, owned by James Cryer, was from the stock of Boswell Johnson, a Virginian, who settled as a close neighbor to Cryer. Among Madam Tonson's ten foals were four sons by Pacolet: Monsieur Tonson, 1822; Sir Richard Tonson, I823; Sir Henry Tonson, I824; Champion, $1826 .{ }^{1}$

Black Sophia was by Elliott's Top Gallant, dam by Lamplighter, grandam by Beeder; - by Buie (alias Bowie, alias Bouye). Lamplighter was by imp Medley.

${ }^{1}$ For further information see sketches of James and Rev. Hardy M. Cryer and Thomas Foxhall. 


\section{Sumner County, Breeding, Centre iof}

Beeder was by old Union and out of a full blooded Medley mare. See "Buoy, alias Buford's Defeat."

Black Sophia ran at Bledsoe's and Mansker's creeks; in Wilson and Lincoln Counties; in Mississippi; and at Green Bottom Inn, near Huntsville, Alabama - six or seven races in all - and won every race. Elliott owned her many years and later she was owned by CoI. A. B. Newsom. Newsom sold to Andrew Jackson, Jr., and other Alabama men, one half interest in her and two of her colts for $\$ 6,000$. Bruce says "she was one of the best brood mares in America."

Among her produce when Elliott owned her were Morgiana by Pacolet, 1824; Jerry by Pacolet, 1825; Fortuna by Pacolet, 1826; Parasol by Napoleon, 1827; and Birmingham by Stockholder, I83 I. When Newsom owned her she produced Catherine Barry, later called Beeswing, by Leviathan, 1835. She produced eight foals, the last, in $184 \mathrm{I}$, by Stockholder.

Morgiana ran eight races in Tennessee, Alabama and Missisippi and won six. After Fortuna had run four races and won three, Elliott sold her for \$2,000. Jerry's seven victories, out of ten races run, were won at Nashville, Natchez, New Orleans and other places.

\section{Performances of Produce}

Now, as to this parent-stock's near descendants:

All of the produce above named were more or less famed on the turf and as stallions or brood mares. But Oscar and the "four Tennessee Tonson Brothers" did more than any other horses, before 1829 , to establish the reputation of Sumner County's native-bred stock.

Monsieur Tonson was 5 feet 3 inches high, a beautifuI blood bay with black legs, mane and tail. AII his markings showed the bluest blooded aristocracy. 


\section{In2 Making the American Thorougbbred}

In his first race, run in 1824 , when thin and out of condition, he was defeated by A. B. Shelby's Pacolet filly, Maria. Three weeks later, at Cairo, Sumner County, he beat Maria and others in a mile-heat race. In the spring of 1825 he won the Jockey Club purse at Gallatin, 2-mile heats. In the fall of that year he won the great colt stakes at Gallatin, I I entries, $\$ 200$ each, again beating Shelby's Maria, Col. Robert Smith's, Andrew Jackson and others. Time 1:50-1:51. A few days later, at Florence, Alabama, he beat Andrew Jackson again - and others. From Florence he was taken to Natchez to run there and at New Orleans, but took the distemper and thrush and did not start. In the spring of I826 Henry M. Clay bought a half interest in him and he travelled I,200 miles to Milton, North Carolina, in June and commenced his career in North Carolina on Sept. 21, by winning a 2-mile heat race. The next week, at CasweIl Court House, he beat Sally Walker, by Timoleon, in a 2-mile heat race. On Oct. I9 following, after travelling I 50 miles, to Tree Hill near Richmond, Virginia, he beat the famous Ariel, Gohanna, and Blenheim in a 4-mile heat race. Two weeks later he beat Ariel, Sally Walker and LaFayette 3-mile heats at Belfield. The next week at New Hope, he vanquished Shakespeare in a 3-mile heat contest. Two weeks later at Boydton, Virginia, he beat Sally Walker in a 4-mile heat race, which for many years afterward was regarded in Virginia and elsewhere as the best race ever run in the United States. The track was pipe clay and hilly and at that time very wet, tough and heavy. Time 7:56-7:55. In the spring of 1827 he was lame and did not run. In the following September at CasweIl Court House, North Carolina, in a 3-mile heat race with Frantic he wound up his turf career on three legs - but he wound it up a victor and the recognized superior of any horse of his day. 
Sally McGee, in six successive races, beat all her competitors except Sally Walker and later maintained her brilliant reputation "in the west." Sally Walker was considered greatly superior to all other race horses that ran in "this country" from Timoleon's day to I833 - except her only successful competitor, Monsieur Tonson.

After Mons. Tonson had become distinguished on the turf he was purchased by Orville Shelby for $\$ 1,000$, and after he had beat everything from Nashville to Natchez, Green Berry Williams sold half interest in him for \$1,000. Sir Henry Tonson, Sir Richard Tonson and ChamPION were on a par with their oldest brother, as race horses. The Turf Register of March 1, 1835, printed a picture and sketch of Sir Henry Tonson, furnished by Balie Peyton. In both picture and sketch due notice is taken of a peculiarity which Henry inherited from his sire. Henry, like Pacolet, was a dapple gray, with "a red belt passing from midway his back around the near side - sure pledge of his Arabian origin." Henry was I5 hands 3 inches high. At two years of age he was sold for the then enormous price of $\$ 2,200$ to $O$. Shelby, who put him in training in charge of John C. Beasley and found him to be a colt of superior qualities of speed and bottom. In bleeding him his wind pipe was permanently injured, cutting short his once promising career on the track. But even under this physical disadvantage he scored one notable victory as a 3-year old at Gallatin. After winning the frrst heat over Mr. Malone's Negro, by Pacolet, and CoI. Robert Smith's Oscar, and while in front, in the second heat, he bounded through the field, came back on the track sixty yards behind his competitors and won the race by several lengths, though his bolt lost him the money. He started only one other time. 


\section{I04 Making the American Thorougbbred}

Neither Sir Richard Tonson nor Champion, "although each bantered and ran against the world," was ever beat; and Henry, but for his injury, was considered their equal. Champion is said to have been sold for $\$ 3,000$ before he ever ran a race ${ }^{1}$ and in 1831 he was held at $\$ 10,000$. "Richard," said Judge Williams, "was the most beautiful horse that could be led into a show room."

In the Tonson brothers were united the crosses of Citizen, Medley and Bedford, and being of different types, also, from the Archy stock, their blood was much sought to mingle with that of the descendants of Diomed. In I833 Col. W. R. Johnson, who owned many mares of the Archy and Eclipse stock, paid $\$ 10,000$ for Mons. Tonson to use as a sire.

Among Mons. Tonson's distinguished get that joined the stallion class were Anvil who was brought to Sumner County, Drone (sold for \$5,000) who stood in Virginia, Governor Burton who stood in South Carolina and Rhoderick Dhu who stood in North Carolina. AII four of these horses were grandsons of Sir Archy, the first two out of Isabella, the last two out of Lady Burton. Argyle, another son, started I 8 times, won II, five of them 4mile and two 3-mile heats. Champion was destroyed by disease; Richard died young but left some fine stock; Henry was a great success in the stud.

Betsey Malone, next in point of time, was the most distinguished product of Sumner County. Of her Wallace says: "Foaled 1829; got by Stockholder dam by Potomac g. dam by imp Diomed. Nothing more is known with certainty of the blood of this wonderful animal, but her performances on the turf at all distances and her produce in the stud, entitle her to a very high place in the true horse

1 Peyton says he was sold at this price while at the head of the turf. 
aristocracy. Out of 22 races at all distances she lost one, and she produced Charmer." 1

Betsey Malone was foaled the property of John Wesley Malone, of Sumner County, and was named by him for his wife. Tradition in the Malone family is that this mare never lost a race. ${ }^{2}$ She was trained by John Malone and Green Berry Williams and ran in Nashville, Natchez and other Southern cities. A news item in The Spirit in 1838 stated that Richard Beasley, of Nashville, had sold to W. J. Minor, of Natchez, Betsey Malone and her colt by imp Consol, of Alabama, for $\$ 2,200$.

\section{Celebrities of the i830's}

Among the most successful racers in the United States, I836-39, inclusive, were the following named descendants of the above mentioned parent stock. AII of them were foaled in Sumner County unless otherwise stated.

Angora (Gen. Robert Desha's), foaled 1832; by Leviathan, dam Patty Puff. See Angora vs. Rodolph, post.

Sarah Bladen (Col. George Elliott's), foaled i 834; by Leviathan, dam Morgiana. She won $\$ 11,500$ in six races and forfeitures in 1836-38. See "The Leviathans vs. The Luzboroughs," post.

In Skinner's table showing the best time on record at 2-mile heats prior to 1847 , Sarah Bladen is put down as making that distance in 3:46 at New Orleans, March 17, I842; in the 4-mile heat races she is credited with 7:457:40, at New Orleans on March 17, 184I. Referring to an entirely different race from the above the Editor of

1 Bruce says Betsey Malone's second dam was by imp Diomed and her third dam by Pegasus. Charmer was by Glencoe.

${ }^{2}$ A writer in The Turf Register said she never lost a beat except the one in which she fell. Judge Jo C. Guild said she never lost a race except the one in which she fell. 


\section{Io6 Making the American Thorougbbred}

The Turf Register wrote in February, 1843: "To this day the Turfmen of the Old Dominion and of the North will not concede that any performance made at New Orleans equals that of Sarah Bladen who, at eight years old, with her full weight up, ran 4-mile heats in 7:37-7:40."

(3) Birmingham (Col. George Elliott's), foaled i83i; by Stockholder, dam Black Sophia. Sold for $\$ 700$ to A. B. Newsom, who sold him for $\$ 2,500$ to Dr. Scott of Benton County, Alabama, who sold him for $\$ 4,500$ to Maj. Kean of Mobile. After several victorious campaigns Birmingham, in the presence of a great crowd at Mobile, in April, I837, as the entry of P. B. Starke, defeated CoI. Vance Johnson's Scarlet in a match race, 4 -mile heats, for $\$ 5,000$. Scarlet was by Waxy (son of Sir Archy) dam by Tiger. Scarlet distanced first heat. Time r:54- $1: 54-\mathrm{r}: 55$ - 2:05. Total 4 miles 7:48. The Spirit said Birmingham could have made better time, but, as it was, proved himself "one of the very best horses on the American turf." At this same meeting four days later he was allowed to take down a $\$ 1,000$ purse without opposition. In I 838 he was taken to Kentucky for use as a stallion and in 1839 Y. N. Oliver \& Co., of New Orleans and Louisville, sold half interest in him to Throckmorton and Prestbury of Louisville for $\$ 4,000$. As a stallion he earned a place in the list of celebrities.

(4) Linnet, ${ }^{1}$ foaled I832, by Leviathan, dam Object by Marshal Ney by Pacolet. James Jackson sold her as a 3-year old to W. J. Minor of Natchez, Miss., for $\$ 3,000$

1 The fact that Linnet was Iater owned by James Jackson probably caused some writers to say she was bred by Jackson. General Desha who lived in Sumner at the time, said she was bred in Sumner. Bruce credits John Duncan of Alabama with owning Object. The fact that Object produced nine foals by Leviathan indicates a long residence in Sumner. At any rate she was of Sumner County stock. 
and Minor sold her to T. J. and M. Wells of Alexandria, Louisiana, for $\$ 6,000$. Wells Brothers refused an offer of $\$ 12,000$ for her. In seven races run in $1836-7-8$ she won more than $\$ 20$, 000 in prizes. In a match race for $\$ 10,000$ a side, $\$ 5,500$ bye, mile heats, set for December 15,1836 , at Alexandria, Louisiana, Linnet received forfeit of $\$ 5,000$ from Francis Henderson's Coahoma, by Mercury, dam by Sir Peter Teazle. In 1838 , in a 4 -mile heat race at New Orleans for a \$2,00o purse she beat, among others, A. L. Bingaman's Fanny Wright (by Bertrand), "Crack of the South," who, in 1837 , had won six 4-mile heat races aggregating $\$ 9,000$ in purses. In 1838 at Natchez, Linnet won a $\$ 10,000$ sweepstake from Angora. Angora's jockey fell off and Linnet got the money, but the respective merits of these two half-sisters from Sumner was not decided.

In addition to the more than $\$ 20,000$ winnings referred to above, Linnet received $\$ 5$,ooo forfeit on an inside bet of \$10,00o with CoI. Osmund Claiborne's Hinda (Susan YandeII) by Sir Richard Tonson, dam by Rockingham, in a 4-mile race won by Fanny Wright at Natchez in March, 1837. Both Hinda and Linnet were out of sorts and the latter was distanced the first heat. Linnet was the favorite.

(5) Zelina, foaled I833, by Leviathan, her dam (a sister to Betsey Malone) by Stockholder. Afterward owned in turn by Eli Abbott, J. B. Jones, Johnson \& Tayloe and Henry H. Tayloe of Alabama. In 1836-7-8 she won three 4-mile heat races, five 3-mile heat races, two 2-mile heat races and four mile-heat races, her winnings amounting to $\$ 13,900$. In this list was a $\$ 5,000$ sweepstake won over Gen. J. A. Mabry's fine racer, Hugh Lawson White, by Leviathan, dam Julia Franklin by Conqueror, at Tuscaloosa, Alabama. At New Orleans, in December, I838, she beat Linnet in a 2-mile heat race for a $\$ 10,000$ purse; time 4:07-4:09. 
(6) The Poney (Col. Jesse Cage's), foaled I834; by Leviathan, dam by Stockholder; later sold to Thomas J. Wells, of Alexandria, Louisiana, for $\$ 3,000$. In six races - two of 4-mile heats, three of 3-mile heats and one a mile heat, run within the two years ending March I5, I839, The Poney won \$12,100. Ten thousand dollars of this sum was won in a match race at Mobile, 4-mile heats, with David Stephenson's Melzare, by Bertrand, dam Madam Bosley, by Sir Richard Tonson; time 7:48- 7:56. Four days later, on March 15, 1839, at the same place, The Poney defeated four competitors in a 4 -mile heat race for J. C. P., \$1,00o. After his racing career was over he became celebrated in the stud.

(7) Beeswing, by Leviathan, dam Black Sophia. Foaled 1835, as property of A. B. Newsom of Wilson County; at 2 years old sold to Jo C. Guild and Balie Peyton of Sumner, for $\$ 2,000$. Peyton Iater sold his interest for $\$ 1,500$ to T. J. and M. Wells of Louisiana and Beewsing joined the Iong procession of Sumner County horses that went South. In eight races run in I838 and I839 she won $\$ 14,100$ for her owners. In her list of victories was a $\$ 5,000$ match race in 1838 with Willina Herndon (by Woodpecker dam by Whipster), 4-mile heats, at New Orleans; time 8:15-8:37. On March 6, 1839, at New Orleans, she won $\$ 5,250$ in a sweepstake, four running; time $3: 44-3: 47$. Six days Iater at Mobile she distanced two competitors - one 5 and the other 6 years old - in a 2-mile heat race for a purse of $\$ 700$.

In a statement of the best time on record at 2-mile heats up to December I, 1846 , Beeswing is one of the twelve horses mentioned. Her time was $3: 44-3: 47$, made at New Orleans, March 26, I839.

In winding up her successful turf career in New Orleans 
in 1840 , Beeswing ran a 4-mile heat in 7:38. This was better than Peytona did in her race with Fashion; it was only one half second behind the best time made in the Eclipse-Henry race. It will be borne in mind that Sarah Bladen's time of $7: 37$, previously stated, was better than either heat of the Eclipse-Henry contest.

(8) Lavinia, foaled 1835, by Leviathan, dam Parasol (by Elliott's Napoleon). Bred by Col. Robert Smith of Murfreesboro. She won seven mile-heat races in Tennessee, Alabama, Mississippi and Louisiana, in 1838. Sold to B. M. Grissett, of Alabama (along with Lizzy Diggs by Leviathan, dam by Tennessee Oscar), for $\$ 6,000{ }^{1}$

It must not be assumed that these results came from haphazard ways of breeding. Mating was a science, and the chief pleasure that most breeders got out of the turf was in watching the practical test of their theories - the joy of achievement. This fact must be kept in mind by all who would get at the heart of the thoroughbred industry before one branch of it came under the blighting influence of the bookmaker. Conceding this much to the impelling power behind the breeders it may be easily imagined how the news of the victories above enumerated, leaking back through the wilderness by way of the Natchez Trace, or by Mississippi steamer, stirred "the grand old county of Sumner" from the head of Goose to the mouth of Mansker.

Other successful horses bred in Sumner County at this same period, and wholly, or in part, from the above mentioned foundation stock were:

1 Between Oct. I, 1829 and May 8, I835, Black Maria won \$ 4 4,900. Trifle, a nonpareil, and the most successful racer of her day, won $\$ 14,380$; Post Boy won $\$ 12,700$. In nine 4-mile heat races Boston won only $\$ 7,600$ in purses. Atalanta in three races in New York and New Jersey won \$1,500. Fanny Wright, "crack of the South," in six races won \$9,000. Comparatively speaking the Sumner County stock made a very good showing. 


\section{I Making the American Thorougbbred}

(9) Daniel O’Connell, foaled 1832; by Sir Henry Tonson, dam by imp Sir Harry; grandam by imp Diomed. Bred by G. W. Parker and sold to Col. Robert Smith of Murfreesboro for \$I,200. Later he went south. After closing his career on the turf he became celebrated as a stallion. As a 2-year old he ran a mile in $1: 49-$ an unusual feat for his period.

(io) Queen of Trumps (Jesse Cage's); foaled I 835; by Leviathan, dam Fanny Maria by Pacolet; sold to Thomas J. Wells of Louisiana.

(I I) Fanny Bell (Jesse Haynie's); foaled 1833; by Murat, dam by Tennessee Oscar; sold to Col. Robert

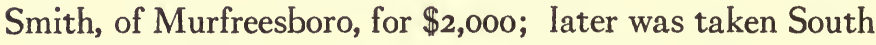
and her promising career begun in Sumner County was cut short by incompetent handling.

(12) John Malone (formerly Dr. Duncan) (Jo C. Guild's); foaled 1836 , by imp Leviathan, dam Proserpine by Tennessee Oscar.

(13) Boyd McNairy (George Elliott's); foaled i836, full brother to Sarah Bladen. After a successful career on the turf served as stallion in Kentucky.

Still other chips off these old foundation blocks, contemporaneous with those named above, were:

(14) Hortensia, by Pacific, dam Bet Bosley by Wilkes' Wonder; bred by Duke W. Sumner, of Davidson.

(I5) Narrcissa Parrish, by Stockholder, dam by imp Eagle; bred by William McCrory, of Davidson.

(I6) JIM PolK, by Stockholder, dam by imp Eagle; bred by Henry Smith, of Maury, and sold by him for $\$ 2,500$.

All of these horses were sold to Mississippi and Louisiana and proved true to their family name and reputation, in the rivalries between their new owners. 


\section{Sumner County, Breeding Centre}

\section{Expectations and Realizations}

The important place occupied by Sumner County in the estimation of sportsmen of the entire country is well illustrated by a letter written by Balie Peyton from "Station Camp" on July I, 1837, to The Spirit of the Times, in which he said:

"The sweepstakes to come off over the Gallatin Course at the Fall meeting 1840, 2-mile heats, for $\$ 1$, 000 (each sub.) $\$ 250$ forfeit, has closed with 23 subscribers. The nominations comprise ten of the get of imp Leviathan, three of imp Luzborough, three of imp Consol, two of imp Merman, one of imp Whale, one of imp Chateau Margaux, one of imp Priam, and two Bertrands. A more promising Iot of colts, if we are to judge from their illustrious ancestry, has never been named for any stake, at least upon these waters. Large expectations are entertained. ... We have in this stake entries of the most splendid turfmen in several of the adjacent states. One - and a counter - will be from the Old Dominion - several from Alabama, Mississippi." 1

Other evidence - without meaning to, say it is all picked up at random is here given:

All of the six races run at the Nashville spring meeting, 1838; four of the five at the Nashville spring meeting, 1839; and four of the seven at the Nashville September meeting, $184 \mathrm{I}$, were won by Sumner County horses; most of them wholly, and the others in part, descended from one or more of the foundation sires or dams, or both,

I The Barry Sweepstakes for 3-year olds, 2-mile heats, \$1,000 entrance, $\$ 250$ forfeit, 23 subscribers, was run at Gallatin Sept. 14, 1840. Three started: Thos. Barry's Celerity, by imp Leviathan, dam Patty Puff; G. W. Parker's Flight by imp Leviathan, dam by Sir Charles; and Samuel Ragland's Lady Sherbrooke, by imp Priam, dam an imported mare by Woful. Celerity won the first heat in 3: 49, but fell in the second and Lady Sherbrooke tumbled over her. Flight then went home and pulled down the $\$ 8$, ooo, which was $\$ 900$ more than the "Great Inauguration stake" at the opening of Jerome Park, New York, in October, 1866. 


\section{2 Making the American Thoroughbred}

named in this chapter. The four winners in $184 \mathrm{I}$ were owned by Charles Lewis; three of the four were by Leviathan. Another of Leviathan's get, owned in another county, won at this meeting. In 184 I A. P. Yourie jogged out to Carrollton, Booneville and Dover, Missouri, with three samples of Sumner County "nags," won six races, lost one and paid forfeit in one. He "showed 'em" so well they thought he was a native of their own state.

\section{Wagner and Albion}

In I843 Maj. Geo. A. Wyllie brought Wagner, by Sir Charles, dam Maria West by Marion, to Sumner County; and after Leviathan's death Col. Elliott put Albion at the head of his stud.

Wagner played a leading rôle in two of the most memorable contests in the annals of Kentucky racing. At Louisville, on Sept. 30, 1839, he met the great Kentucky champion, Grey Eagle, by Woodpecker, in a 4-mile heat contest for a sweepstake, \$14,000. Wagner was $1_{5}^{\frac{1}{2}}$ hands high, a handsome chestnut with a blaze in his face and white hind feet. Grey Eagle was "one of the finest looking horses that ever charmed the eye. He was I6 hands high, a beautiful gray, with flowing silver mane and tail." Wagner was owned by John Campbell, of Maryland, and run by James S. Garrison, of Louisiana; Grey Eagle was owned by A. L. Shotwell and run by Oliver and Dickey. All Kentucky witnessed the race and not a dollar of Kentucky money was bet against Grey Eagle; that would have been an unpardonable sin. Wagner won the first heat; the close of the second is thus described by Editor Porter of The Spirit:

"From the Oakland House home it was a terrible race. By the most extraordinary exertions, Wagner got up neck and neck with the gallant gray, as they swung round the turn into the quarter stretch. The feelings of the assembled thousands were wrought up to 


\section{Sumner County, Breeding Centre}

a pitch absolutely painful. Silence the most profound reigned over that vast assembly as these noble animals sped on as if life and death called forth their utmost energies. Both jockeys had their whip-hands at work, and at every stroke each spur, with a desperate stab, was buried to the rowel-head. Grey Eagle, for the first hundred yards, was clearly gaining; but in another instant, Wagner was even with him. Both were out and doing their best. It was anybody's race yet; now Wagner, now Grey Eagle, has the advantage. It will be a dead heat. 'See, Grey Eagle's got him!' 'NoWagner's ahead.' A moment ensues - the people shout - hearts throb - Iadies faint - a thrill of emotion, and the race is over. Wagner wins by a neck in 7:44, the best race ever run South of the Potomac."

Kentucky made a motion for a new trial, which was granted, and the horses met again five days later on the same course, same distance, same crowd - or larger and more excited. Grey Eagle won the first heat, Wagner the second; in the third Grey Eagle broke down - and so did Kentucky.

Of 20 races run, Wagner won I4, I I of them being of 4-mile heats; his earnings $\$ 36,200$.

Wagner's fame, therefore, preceded him to Sumner. But with Albion it was quite different - he had no fame to precede him. It was not known who imported him. He was landed at Charleston, South Carolina, in the ship Cbina, in January 1839, and was purchased at auction by Col. Geo. W. Polk for $\$ 1,600$. He was trained awhile at Richmond and was later sold to Lucius J. Polk who kept him in the stud several years and then sold him to Col. Elliott. Tradition, supported by the records, is that Albion was a failure in the stud until he went to Elliott's. At any rate Wagner and Albion (and imp Sovereign who also stood at Elliott's) well sustained the reputation which their predecessors had given to Sumner County as a producer of fine stock. Albion's dam was Panthea, by Comus or Blacklock. 


\section{Chapter VII \\ TENNESSEE AND NORTH ALABAMA}

Col. George Elliott, after the passing of his elder contemporaries, continued "the dean of the institution" among all the younger men, who, prior to the Civil War, Iabored zealously to keep Sumner's greatest industry up to the high standard set by "the fathers."

Thomas Barry, who, late in life, was Chancellor at Gallatin, succeeded his father at "Barrymore." He did much to improve Tennessee stock and was a frequent contributor to The Turf Register; and to similar publications of later days, down to the time of his death about 1892 . To Judge Barry the passing of the old time 4-miler was the cause of great regret.

James Cryer's son, Rev. Hardy Murfree Cryer, was born in North Carolina in 1792; married in 1812; was a member of the Tennessee Conference, Methodist Episcopal Church, 1813-16, and served one year on the Nashville district. After withdrawing from the itinerant ranks he served as a "local" preacher and continued to exercise the offices of a minister the remainder of his life. His many contributions to The Turf Register and The Spirit of the Times are rich in Biblical and classical allusions, after the style of that day; show much force and originality; and amply support the statement of McFerrin that he was of an ardent temperament and had a brilliant mind. His ardor distinguished him as a breeder no less than as a preacher. He kept more thoroughbred stallions 


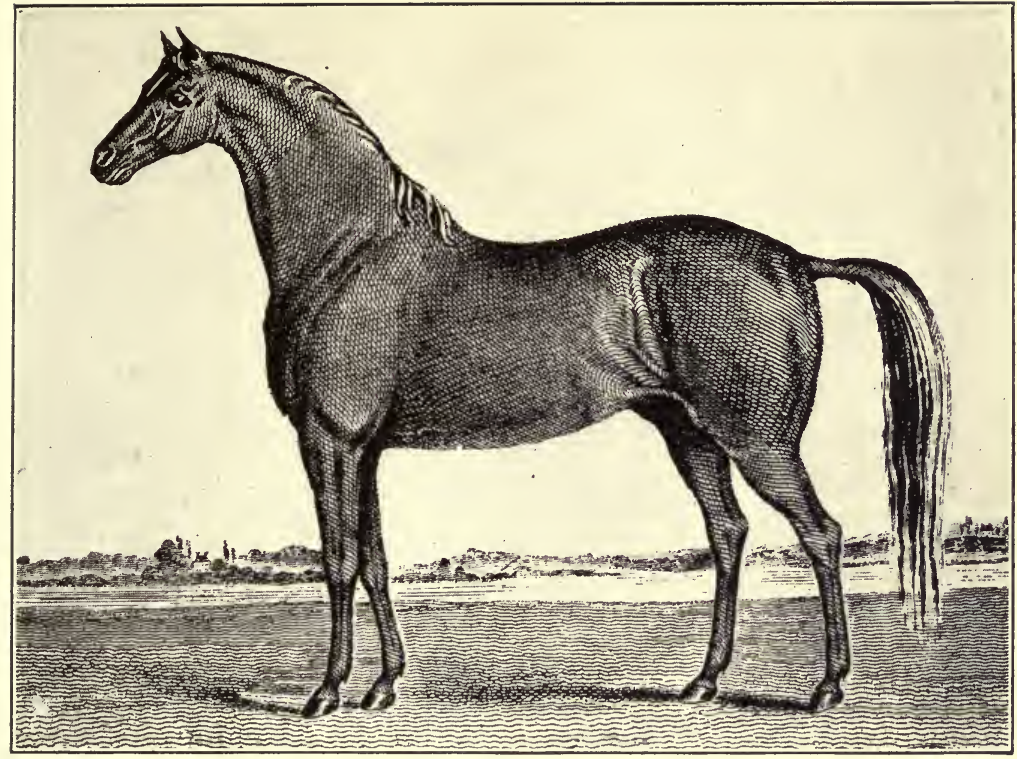

Timoleon

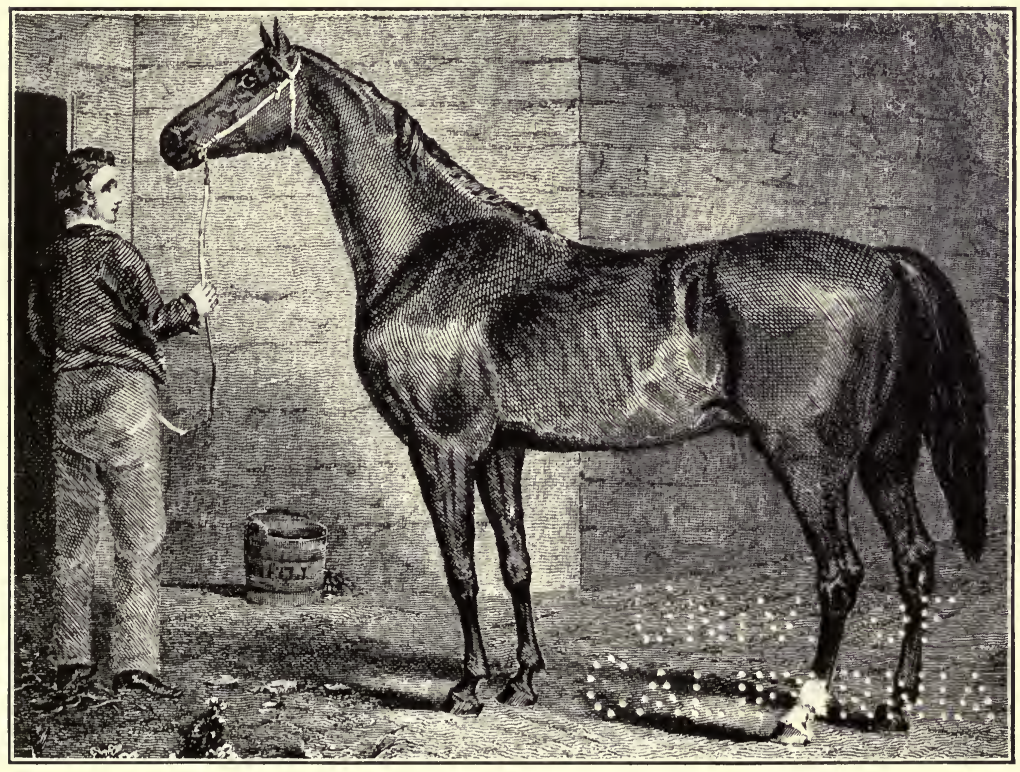

American Eclipse 

than any man of his time except, perhaps, Thomas Alderson; owned a few brood mares; and took a great interest in turf events. From his father he inherited Madam Tonson, and after her death (as his property) he wrote her obituary, in which he said:

"The last display of inimitable grandeur she ever exhibited was in my yard. The grooms of Arab and Havoc had been making a display of them both, in view of each other, and they became much excited, threw themselves in lofty attitudes and were dismissed. The old mare had just been turned into an adjoining lot, but was a spectator of what was going on. After the stallions were stabled, the gate was opened; she walked back and no one thought anything more about it, till she walked up to the very spot where those daring fellows had been whatting and coming again. She looked agitated - commenced pawing the earth and snorting; at last she raised her full flowing tail, and, for several minutes walked the yard 'with the tread of dominion in her haughty step,' as much as to say, 'Ye peerless steeds, though ye are as the feathered Mercury, look at me, the mother of the Gracchi. Though I am old and near my journey's end, still there will one arise from me (the Phoenix of the West) that will perpetuate my name with my youthful charms.'

“ . . I I gave her a decent grave, my wife and children all protesting against the dogs and buzzards rioting on her carcass."

Thus did the thoroughbred enter into the hopes, affections and daily life of past generations. ${ }^{1}$

Not the least interesting phase of Cryer's career was the friendship existing between him and President Jackson, as set forth in the Appendix to this volume.

Maj. J. R. Hubbard ("Albion"), writing in The Spirit of The Times of a trip to Sumner County early in the I880's, said this of Rev. H. M. Cryer:

"He was a man of strong common sense, and of decided influence with the people. He got into difficulties at one time with his church. He was charged with horse-racing, and summoned to trial before a church tribunal. The proof was clear and conclusive, but the evi-

${ }^{1}$ See Addenda $\mathrm{H}$. 


\section{6 Making the American Thorougbbred}

dence showed that the horse was raced in the name of Col. George Elliott, and that this gentleman owned one-half of him. After all the evidence had been taken, Mr. Cryer was asked by the Judges if he had anything to say in his defense. 'Nothing,' was his reply, 'except that I would like for you to let me know how I can arrange it for my half of the horse to stand in the stable while Col. Elliott's half is racing. The horse belongs to us jointly. He has the same right to control him that I have, and he will race him and I cannot keep him from it.' It is needless to say that the defense was complete and an acquittal inevitable."

The fortune inherited by Cryer was not squandered on race horses; $\$ 50,000$ of it went to discharge surety obligations incurred for three friends.

Cryer, like Saunders, was more orthodox - in one respect, at least - than many Methodists of the present day who taboo the race horse - he was the father of thirteen children. Nor were these two ministers any the less pious because of their race-horse affiliations. Cryer and Saunders "talked horse" till time for family prayers and after rising from their knees "talked horse" late into the night. Cryer was not able to attest his devotion to Methodism by founding a church; but his faith he put of record in his Bible, in his hours of darkest gloom, as one after the other of his little ones was laid to rest. Which being so, who can doubt or criticise after reading this Bible entry written and signed by one of his sons:

"Hardy M. Cryer Departed this life on the evening of the seventh of February, 1846- He was a kind Father and Christian."

The name of Thomas Foxhall, an adventurer from England, got into the thoroughbred annals of Sumner County by reason of the fact that he, a very young man, married the aged widow of James Cryer. For mistreating her he had the honor of being horsewhipped by her ministerial son. 
Foxhall is credited by Balie Peyton and others with having bred the four Tonson brothers, whose dam, as shown above, was left by James Cryer to his son, Hardy M. Cryer.

Jo C. Guild, who served five terms in the legislature, a brief time as Chancellor and one term as Circuit Judge, and who was twice a Democratic elector, actively engaged in raising horses before 1830 and kept at it until after the Civil War. Proserpine (dam by Pacolet) produced for him, besides John Malone, Caroline Malone and four others by Leviathan. Flight, by Leviathan, brought him Oliver by Wagner. A daughter of Black Sophia, bred to Wagner produced a mare that foaled Hiawatha, by Albion, and eight other colts, among which were Capitola, Duke of Orleans, and Nannie Douglass. Gloriana, by American Eclipse, produced for him Jack Malone by Lexington, and Lucille and Patrician by Hiawatha. Hiawatha, Jack Malone and Beeswing were the three most famous horses Guild owned.

In a race of "two miles and repeat," run over the Albion course at Gallatin, Hiawatha beat Dan Calgy's Pot8os and Eli Odum's Mary Wyllie, foaled 1855, by imp Albion, dam by imp Sovereign; - by imp Leviathan; - by Bertrand. A statement made by Odum to the effect that Mary Wyllie's defeat was due solely to the breaking of her bridle-bit, "brought on more talk" - and that of the heated sort - between Guild and Odum, and it ended in Guild accepting Odum's banter to run his mare against Guild's horse for $\$ 6,000$ a side, 4 -mile heats, over the Nashville course. Each horse had a host of "friends"; the contest, originating as it did, caused great excitement and much betting. An immense throng witnessed the event. Hiawatha won the first heat. In the second, Mary set out from the first to run him down. For the 


\section{8 Making the American Thorougbbred}

first three miles they ran head and head; then Mary weakened and Hiawatha left her, and, seeing she was done for, came in under a strong pull. If Mary had made Hiawatha run it through, experts - it is pleasing to note-

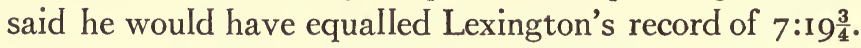

After this race Guild sold Hiawatha to Dr. James Bradley for $\$ 6,000$ cash, but bought him back, after he broke down in a race at Memphis, and put him in the stud where he proved a great success. He lived until his twenty-fourth year and was buried on Guild's farm, a short distance south of Gallatin.

Balie Peyton's stud usually contained fifteen or more brood mares. Among those he owned prior to 1840 was the aged Lady Burton, by Sir Archy, dam Sultana who was out of the mare and by the horse sent as a present by the Bey of Tunis to President Jefferson, who sold them and deposited the money to the credit of the United States. Others were imp Anna Maria; Maria Shepherd, by Sir Archy; Minerva Chance, descended from Craig's imported Highflyer; and Lilac (by Leviathan), Gen. J. A. Mabry's famous racer, for whom Peyton paid $\$ 3,400$.

In 184I John C. Stevens, of New York, presented Peyton with Cora, own sister to Medoc. In conjunction with Gov. Butler of South Carolina, Peyton, in the same year, purchased of Col. W. R. Johnson and Capt. D. H. Branch of Petersburg, Virginia, Trifle, by Sir Charles and Atalanta, by Industry. Atalanta had beat nearly every prominent horse of her day, and it was Col. Johnson's opinion that she was the only horse in the country that could possibly compete with Boston. Trifle's reputation on the Turf was second to that of no horse ever bred in this country. Of 24 races run she won 20,14 of them being of 4 -mile heats. Her dam was by Cicero, son of Sir Archy; and she traced, on her dam's side, to 
Bedford and Medley. Cora, from an injury, left the turf at 3 years, but was considered a flyer. AII of these mares were kept at "Station Camp."

When purchased, Atalanta was in foal to Boston and Trifle to American Eclipse. For each of these foals, as sucklings or yearlings, their owners were offered more than they had paid for both mares. Atalanta's foal was named Cost Johnson and became celebrated. Trifle produced two other foals by American Eclipse: Miss Peyton (in I843) and Gloriana (in I846) later owned by Jo C. Guild, as stated.

In addition to Balie Peyton's horses, there were at Station Camp during the 30's a number owned by two of his brothers, William Randolph ("Ran") and Robert Holmes Peyton. "Ran" Peyton owned Black Kitty Clover, a famous mare by American Eclipse, and a number of young ones by Ratler and Bertrand, valued at from $\$ 1,500$ to $\$ 3,000$ each.

Thus Balie Peyton and his brothers laid the foundation of a stud that produced many fine horses during the next twenty years; and the remnants produced some good ones "after the war."

Satellite, by Albion, out of a Leviathan mare (g. dam imp Anna Maria) ran successfully in England. Satellite's dam, bred to Thomas Barry's O'Meara (son of Glencoe, dam by Leviathan), produced Fanny McAlister (1858), who produced, among others, Muggins by Jack Malone and Richelieu by Hiawatha. Chickamauga, by Jack Malone, was out of Alboni who produced eleven other foals, the last in 1872 . Alboni was by Albion, dam Noty Price by Cost Johnson. All the above named were famous horses of their time.

Col. Jesse Cage, whose farm lay a mile west of Peyton's, at the mouth of Bender's Ferry, or Cage's Bend, 


\section{20 Making the American Thoroughbred}

road, was a prominent figure in all turf matters of Sumner and other Middle Basin counties, and was more than ordinarily successful as a breeder. One of his brood mares was Fanny Maria (by Pacolet) whose dam, by imp Stirling, Bruce says, "came from one of the best racing families in the United States." Fanny Maria produced, among others, Lisbon Maid by Napoleon (1828) and Queen of Trumps. A Stockholder mare owned by Cage produced, besides The Poney, eight other foals by Leviathan (frve unnamed), one by Glencoe and one by Wagner.

The most extensive breeder in Davidson County was Leonard P. Cheatham, a lawyer, and father of Gen. B. F. Cheatham, C.S.A. In I 839 Cheatham owned nine brood mares and about twenty colts and fillies. Gen. B. F. Cheatham, of the Confederate Army, was, himself, a breeder. One of his mares, Cottage Girl, foaled I849, produced fourteen foals. She was by imp Ainderby, dam by Leviathan.

William Williams, of Davidson County, was, in his own words, "an occasional breeder on a small scale," and always kept a few brood mares of the richest blood. As Iate as 1830 Williams and other members of the family had descendants of a horse and mare owned by their father, Elisha Williams, of Scotland Neck, Halifax County, North Carolina, between 1786 and I79I. The horse was the famous Harris' Eclipse by imp Fearnought; the mare by imp Janus. A noted brood mare of her time owned by Williams was Fanny Foster, by Symmes' Wildair, dam by old Partner. Williams lived four miles from Nashville on the Gallatin road. As Circuit Judge he presided over many trials in the Court House, and as Secretary of the Nashville Jockey Club he arranged for many trials on the race track. He attended Harvard with Joseph Story and corresponded with him through subsequent years. 
Also, he frequently wrote for The Turf Register. His most lengthy contributions to thoroughbred literature may be found in The Tennessee Agriculturist, of 1840 , and in "Frank Forester's" "The Horse of America."

William Giles Harding was born at Belle Meade in I808. About I829 he settled on Stones River and lived there several years. In 1839 his father, John Harding, surrendered the management of Belle Meade to him. Many years prior to 1839 John Harding had taken an interest in thoroughbreds; beyond this the records at hand do not speak. It is possible that the following letter, written from Belle Meade to the editor of The Turf Register, shows the beginning of the Belle Meade breeding establishment so well remembered by this generation:

"Sir - This is, I suppose, the acknowledged centre of the "racehorse region.' Blood stock here is all the go. To be without it is to be out of fashion, and destitute of taste. So I too have procured a little bit of the real grit, which by-and-by I hope to increase. I began with old Juliet, by Kosciusko; bred by Col. Singleton of South Carolina, foaled in 1822." After stating Juliet's pedigree and performances Harding continues: "Since it is a custom to bespeak names in your valuable Journal I will claim for all mine at once, the Greek Alphabet from Alpha to Omega, inclusive.

"Alpha, bay, by imp Leviathan, out of Juliet; the first colt bred by me; foaled 1otb Marcb, 1836 . Sold to John C. Beasley for \$1,240, and taken to Louisiana last Fall.

"Beta, ch. f. by imp Leviathan, out of Juliet; of good size and beautiful proportions. She is entered in the Criterion Stake, 4-mile heats, subscription $\$ 1,000$ each.

"Gamma, gr. f. by Pacific, out of Melzare's dam by Sir Richard [Tonson], grandam by imp Eagle, g. grandam by Wilkes' Wonder - Chanticleer - imp Sterling - Clodius - imp Silver-Eye Jolly Roger - Partner, etc. Gamma is a promising filly and has two engagements for next Fall.

"I hope ere long I shall be able to send you a morel interesting account of this Greek Alphabet.

"June Ist 1839."

W. G. Harding." 
Gamma turned out to be a famous racer.

Lucius J. Polk, born in I802, owned "Hamilton Place," a part of a 5,000 acre tract at Mt. Pleasant that was willed by Col. William Polk, of the Revolutionary War, to his four sons, Leonidas, George, Rufus K. and Lucius J. The two last named were devoted to the thoroughbred and owned jointly and severally one of the most valuable stables in the State. In commenting on some of Lucius J. Polk's importations the editor of The Spirit wrote: "It is highly gratifying to see gentlemen of the character, spirit and wealth of Mr. Polk engaging in an enterprise fraught with so much importance in a national and patriotic point of view. In a very few years his breeding and racing establishment will be second to none in the Union."

Maj. Allen J. Davie, who owned Sir Archy in North Carolina, lived in Nashville a few years prior to 1820; and - it appears from the list of subscribers to the Peyton stake - later returned to Tennessee. He was editor of The Turf Register in 1836. He imported many horses into North Carolina.

Judge Robert Weakley, a contemporary of William Williams at the Nashville bar, owned a stallion, BlackAnd-AII-Black, by Madison, son of imp Diomed, dam Virago by imp Whip, and several full blooded mares. George S. Yerger, State Attorney-General and Reporter for eighteen years; his lawyer brother, Jacob S. Yerger; and Montgomery Bell, founder of the still flourishing Montgomery BeIl Academy, are on record as making sales of thoroughbreds. Bell's sale was four Luzboroughs and one Merman, all under two years, showing that even at this early period this Tennessee philanthropist had his heart set on the "young ones."

To this list of Davidson County notables may be added that of United States Supreme Court Judge, John 
Catron, who is on record as owning race "nags." William CarroII, twelve years Governor, doubtless owned a few, as he frequently acted in an official capacity at the races.

In regard to race horses Henry Baldwin, Jr., of Williamson County, followed the example of his father's associate on the United States Supreme Bench, Judge Gabriel Duval, who, during his long service as a member of the highest Court, was one of the Turf leaders of Maryland. In The Turf Register of March, I830, Sir Charles, then the property of Col. W. R. Johnson and B. Moody, was advertised to stand "at the stable of Robert Hurt, Esq. ten miles north of Halifax Court House, Virginia, at \$25." This was Rev. Robert Hurt who later moved to West Tennessee. He was tried by his Church, the Baptist, for "following the fashion" with respect to breeding race horses, but "came clear" on the plea that he never shared in the purses his horses won. Rev. Robert Hurt was the father of W. W. Hurt who, as elsewhere shown, was a successful turfman in West Tennessee, until he returned to Virginia. Rev. Robert Hurt was the grandfather of Gen. W. H. Jackson, of Belle Meade memory.

Among other prominent breeders before 1840 were $F$. Zollicoffer, J. H. Webster, Nimrod Porter, Thomas C. Porter, John G. and Edward Shegogg, all of Maury; Liles E. Abernathy of Giles; Thomas Mumford of Wilson; William Lytle and J. G. Bostwick of Rutherford; John D. Tyler and George W. Cheatham of Montgomery; M. E. Broyles (or Boyles), of La Grange; Charles H. Dickinson, Charles Bosley, John Bosley, M. R. Cockrill, Arnold Russell and Col. Henry L. Douglass of Davidson; Wilson Cage, Reuben Cage, Orville Cage, James Douglass, B. F. Simpson, Thomas C. Trimble, Henry Duffy, Gen. Joseph Miller, Maj. W. H. Harvey and Eli Odum, all of Sumner; Beverly Reece and James H. 


\section{I24 Making the American Thorougbbred}

Bradfute of Williamson, and many others prominently mentioned elsewhere in this volume. A famous brood mare owned by Charles Bosley was Madam Bosley, Gamma's dam. Between 1833 and 1859 she produced fifteen foals. A still more remarkable mare was Duke W. Sumner's Matilda, by Greytail Florizel. She was foaled April 12, 1820. Beginning in 1825 she produced a colt every year up to and including 1842 . The first four colts (ages not given) when sold, averaged $\$ 300$. Of the next nine, all by Pacific, one died and the other eight sold for sums ranging from $\$ 950$ to $\$ 2,000$, the average for the eight being $\$ 1,268.75$. The twelve colts brought $\$ 11,350$, an average of about $\$ 946$. Sales of last five colts not noted.

\section{North Alabama Breeders}

James Jackson was born in Ireland, Oct. 28, 1782. His parents were in comfortable circumstances and he was well educated. With Thomas Kirkman, who married his sister Ellen, Jackson came to Nashville well supplied with coin of the realm and began life as a merchant on the Public Square.

If Jackson did not have the race horse fever when he left Ireland he soon took it in Nashville; as early as 1807 , he owned thoroughbreds. Ten years later he was one of the leading horsemen of Tennessee; and, doubtless, it was to take care of his horses that he moved to a small farm called "Greenvale" "two miles from Haysboro on the Haysboro road."

About I8I9 Jackson, Gen. John Coffee and others organized the Cypress Land Company that bought a large area of land around Florence, Alabama. At the Forks of the Big Cypress and the Little Cypress was a magnificent building site occupied by Doublehead's wig- 
wam. Here Jackson built an "old time" Southern mansion (still standing) and "dispensed a princely hospitality" until his death in 1840 .

"He was equal to most men we have known, in native vigor and intellect," wrote the editor of The Florence Gazette. "He possessed a clear, discriminating judgment, and great firmness of purpose. He was a man of strong passions, had a warm heart and a liberal hand. The claims of suffering humanity were never presented to him in vain. Those whom he believed to be his friends he never deserted, if all others did. He was a liberal contributor to objects of public benefit, and ever ready to patronize what he was convinced would advance the highest interests of his adopted country."

"The eulogy which is paid him in this brief extract speaks the unanimous opinion of his friends in Alabama and Tennessee," wrote the editor of The Turf Register, "and it is grateful to our own feelings to be able from personal acquaintance fully to confirm such encomiums upon the deceased."

"He was possessed of great energy, tact and judgment" - says Brewer's "Alabama," - " which added to an open and manly deportment, wealth and liberality, gave him extensive popularity and influence." He was first elected to the General Assembly in 1822 and was President of the Senate in 1830 . The fact that he came to be a Whig was due in part, if not entirely, to his estrangement from Gen. Andrew Jackson, with whom he had been on terms of intimate friendship. ${ }^{1}$

1 This estrangement is said to have been caused by Gen. Jackson's long delay in paying borrowed money. So bitter was the Kirkman-Jackson hatred of "OId Hickory" that Mary Kirkman's marriage to Gen. Richard K. Call, of Florida fame, was opposed on the sole ground that Call was Gen. Jackson's friend. The mar- 


\section{I26 Making the American Thorougbbred}

The chief industry at "The Forks" was the breeding and training of race horses. At that period there was close affiliation, due to settlement, kinship and commercial interests, between the people of North Alabama and Middle Tennessee. Huntsville and Florence were in the Tennessee Conference until after 1840 and were just as closely identified with the Tennessee turf and breeding industry. Reports of races show that for the next twenty years after moving to Alabama, Jackson had entries at nearly all the best meetings in Middle Tennessee, which fact made his presence - or that of a representative necessary in Tennessee for a great part of the time. He was a sort of non-resident Tennessean.

Thomas Kirkman's four sons, James, Thomas, Hugh and John, actively engaged in the breeding business. Hugh and John lived in Nashville; James in Louisiana and Thomas in Alabama. Thomas and James were associated with James Jackson in the management of his breeding interests. Jackson, and Hugh, Thomas, and James Kirkman, in 1837, owned, severally, about twenty brood mares, kept at "The Forks-of-the-Cypress"; ten were imported and one, Pigeon by Pacolet (Pigeon's dam, imported, by Waxy), was bred by Benjamin McCulloch of Rutherford County, Tennessee. Among the mares returned as James Kirkman's property was Eliza, by Rubens.

Jackson's fame as a breeder is based mostly on the success of Leviathan and Glencoe in the stud.

riage took place at the Hermitage, and when "Old Hickory" called on Mrs. Ellen Kirkman to effect a reconciliation he was persuaded to get out at the point of a loaded pistol in the hands of Mrs. Kirkman.

This was not Gen. Jackson's first experience in helping a friend to out-general obdurate parents. When he was a United States Senator, or about that time, he helped Samuel Donelson steal Polly Smith from a second story window of "Rock Castle" in Sumner County. 
There was a close business relationship between Jackson and Col. George Elliott in all breeding and turf matters; they did more for the stock interests of Tennessee than any two men of their time; no two since their day have done more. No history of Tennessee, or of the American thoroughbred, can be complete without giving them the same place of honor in its pages that they occupied among their contemporaries.

Because of its close proximity to Tennessee and its influence on Tennessee stock, mention of E. H. Boardman's establishment at Boardman's Mills, near Huntsville, Alabama, is here in order. In 1838 it consisted of two imported stallions-Consol and Berner's Comus; nineteen imported brood mares; one native; and thirty-one head under two years of age. These importations had been selected by Richard Tattersall to meet the Iong-distance requirements of horses in this country, Boardman's idea being to save to American breeders the time and money necessary to go to England for stock.

AII of his horses came from noted English studs among others the Royal stud at Hampton Court, Lord Chesterfield's, the Duke of Grafton's and Sir Thomas Stanley's. "It is the only establishment of its kind in the United States," wrote the Editor of The Spirit of the Times," and it is conducted upon a scale so grand, both in regard to the extent and the quality and value of its stock, as to rival the most celebrated studs in England."

Samuel Ragland and Nicholas Davis had stables of fine racers and took many purses on Tennessee tracks.

Another successful horseman near Huntsville was John Connolly. Connolly, and E. H. and John Boardman, like thousands of other "Southern" men of their time, were of Northern birth. The Boardmans, natives of Connecticut or New York, and Connolly, a native of 
I28 Making the American Thorougbbred

Pennsylvania, joined the long procession of Northern emigrants attracted to the South during the cotton "boom" days in the early part of the last century. AII three of these men became leading citizens in North Alabama.

From the foregoing it will be seen that many men of eminence, who left untarnished memories, had a very warm appreciation of the "diamonds of the desert"; and although many of them did not race their horses, they helped to give a strong, aggressive force and vitality to "the manly and gentlemanly amusement, the sports of the turf." 


\section{Chapter VIII}

\section{GETTING THEIR MONEY BACK}

PRIOR to 1840 race tracks were established and maintained - practically all of them under the jurisdiction of regularly organized Jockey Clubs - at Madisonville, Beans Station and Red Bridge near Knoxville, in East Tennessee; McMinnville, Winchester, Murfreesboro, Hartsville, Gallatin, Clarksville, Franklin, Pulaski, Mt. Pleasant, Shelbyville, Fayetteville, Petersburg and Nashville in Middle Tennessee; Paris, Dresden, Jackson, Bolivar, Somerville, La Grange and Memphis in West Tennessee. This list is not given as complete. The Dresden "Social Course," fenced in on all sides, was situated a mile and a half from town and was owned by Willis Nailing. The first meeting was held in September, I838.

In September, I839, a club was organized at Columbia with Gen. Allen Brown, President, Dr. A. H. Buchanan, Rufus K. Polk and Evan Young, Vice-Presidents and Felix K. Zollicoffer (later a Confederate General) Secretary. The course was named the "Ashland Course" and was placed under the supervision of William R. Hill.

Besides tracks located in the various county seats and other towns, where stated meetings were held at regular intervals, there were tracks of a more local nature on which horses were trained and races run at the pleasure of the owners or the neighborhood. 


\section{I30 Making the American Thoroughbred}

Clover Bottom, Gallatin and Nashville each had a Jockey Club as early as i807. Col. Edward Ward was President of the Clover Bottom Club in the year named. In 1808 a three days meeting was held at Fairfield, Rutherford County. At the Bledsoe Creek track in I820, Col. George Elliott's Black Sophia distanced Gen. Desha's Pacolet mare; three of Truxton's get, owned respectively by Col. Weathered, Maj. Lauderdale and Gen. Winchester and CoI. Winn's mare by Ragland's Diomed. At Mansker's Creek, in 1820, Mr. McGavock's Pacolet mare distanced five competitors in the first heat. At Fayetteville, in 1820 , there were five entries at $\$ 1$ oo each. In Wilson County, in 1820 , Black Sophia beat Col. Ed Ward's CEdAR SNAG in a match race for $\$ 500$ a side.

In recounting the performances of Timoleon's get, in an advertisement in February, 1829, David Dancy refers to a two days meeting held by the Fayetteville Jockey Club, a two days meeting at Pulaski and a meeting at Shelbyville.

In April, 1829 there was a two days race meeting at Franklin at which horses ran owned by Messrs. Cash, Olmstead, Perkins and Southall.

At Gallatin, in 1826 , there was a Jockey Club of which Reuben Cage was President. In September, I829 there was ten days racing at Gallatin. In October, 1829 the Pulaski Jockey Club, of which John L. Smith was Secretary, held a two days meeting.

In I829 Jesse Luton, backed by endorsements of John McGavock, Thomas Alderson, Robert Orr, L. P. Cheatham, D. W. Sumner, William Hinton, Col. Robert Smith, Henry Wade and others, as witnesses to his skill as a trainer, started a training track at Franklin. Later Col. Thomas Watson, one of the most skilful trainers of that 


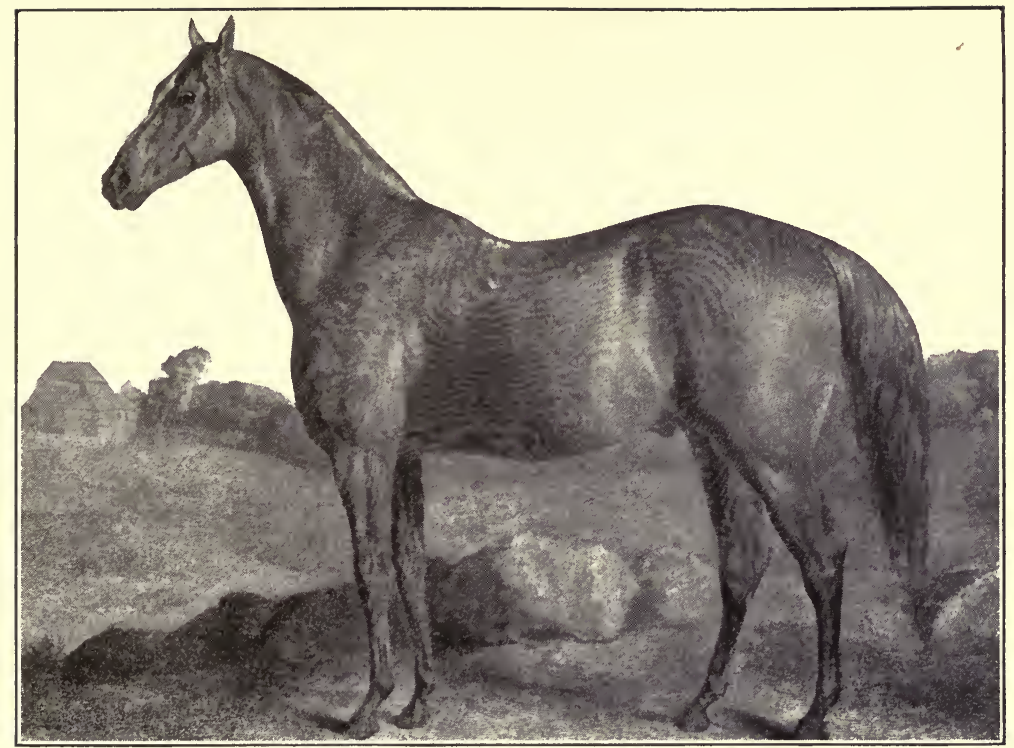

IMP LeViathan

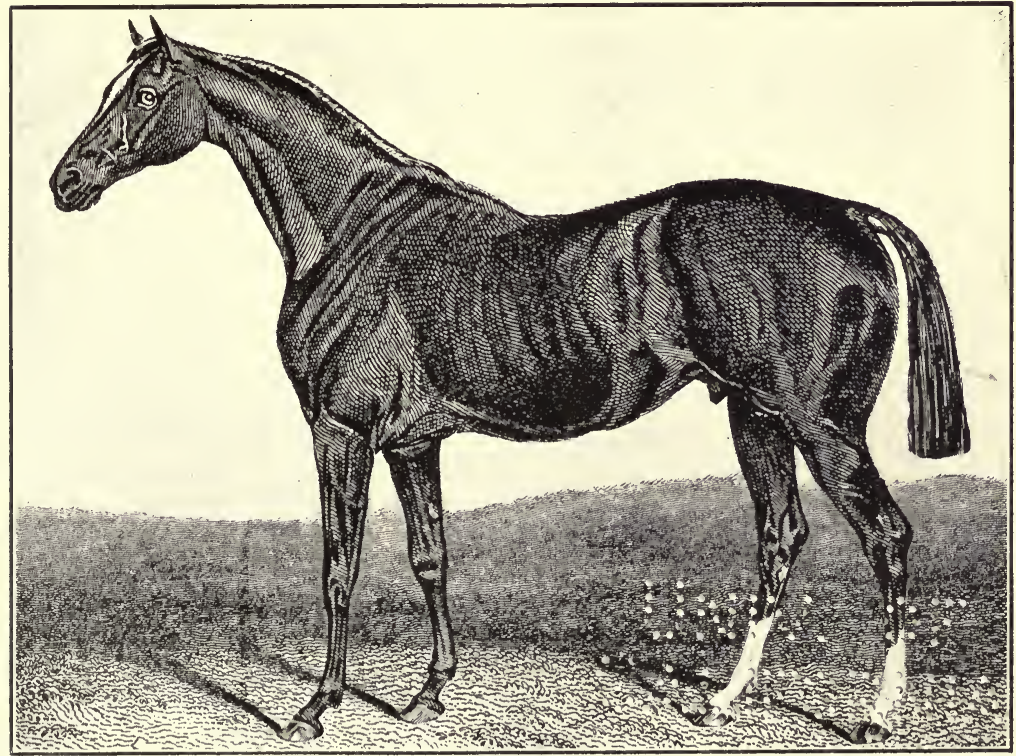

Imp Glencoe 


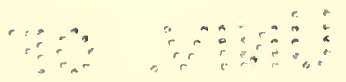

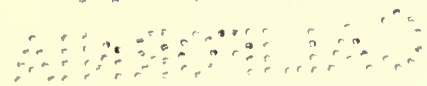




\section{Getting Their Money Back}

period, also had a training establishment at Franklin and trained horses for the leading sportsmen of Tennessee and other states south of it.

\section{Early Day Nashyille Meetings}

Among those who ran horses at the Nashville meetings between 1825 and 1832 were O. Shelby, Thomas Foxhall, George Elliott, Arthur Cotton, Capt. Donelson, Gen. Robert Desha, — Bledsoe, J. W. Clay, Mr. Cheatham, Mr. Beasley, W. C. Davis, proprietor of the track, CoI. J. W. Camp, A. B. Shelby, Major Bibb, S. J. Carter, Mr. McEwen, Mr. Rudd, Mr. Olmstead, Mr. Tompkins.

The officers of the Nashville Jockey Club in 1829 were: Judges, John Harding, Solomon Clark, Francis McGavock, Thomas D. McNairy and Thomas Martin; Timers, Gen. Robert Desha, Gov. William Carroll and William Temple.

In October, I830 the officers were John Harding, President; Dr. McNairy and Duke W. Sumner, Judges; Gov. William Carroll, J. Horton and E. Wilborn, Timers; Judge Phillips and Maj. Marshal, Distance Judges; Messrs. Maxey, Earthman and Brown, Stewards; Messrs. G. Harding, Ewing, Stratton and Higgins, Patrol. In I826 Frank McGavock was Secretary of the Nashville Jockey Club. In 1829 William Williams signed himself "Reporter to the Club"; in 1830 he was temporary Secretary and then Secretary. The Nashville track was then "on a bottom below town on the Cumberland" - near the end of the present Jefferson street.

In The Turf Register of May, I831, "A Western Subscriber" wrote of the Nashville track:

"The half of the track, next the river, is alluvial, and, of course, deep sand; the other half is a sweet-gum flat, and, from the nature of such soil, very hard, when dry, and very tough, when wet; and 


\section{I32 Making the American Thorougbbred}

the whole nearly level, and is considered unfavorable to good time. The same horses run quicker at Gallatin, and other Tennessee courses, by 2 or 3 seconds in the mile.

"The buildings, on the course, are a mansion house, large enough to accommodate the gentlemen of the turf, a dining-room about roo feet long, a stage of the same length, a stage for the judges, and stables, with about 40 stalls, painted white. The course affords a good prospect of the Cumberland river, the new bridge, and the new state house; and the town of Nashville, or, as some of our editors have brevetted it, the city, is seen to prominent advantage. College hill fills up the more distant view."

\section{Race Winnings for Bibles}

In October, 1829 at Nashville, W. C. Davis' Polly Powell, by Virginian, dam by imp Sir Harry, won two races. A few days Iater one Alpha Kingsley wrote Davis "hearty congratulations" on his "successes during the last week's sport" and asked him to "constitute" himself a member of the American Bible Society by making a "contribution of thirty dollars."

This "memorial" was backed up by a petition signed by John Harding, Duke W. Sumner, and Solomon Clark, who told Davis that "our confidence in your well-known liberality induces us to believe that you will not only take a pride but a pleasure in the above suggested donation."

In sending in the thirty dollars Davis wrote:

"Although devoted to the sports of the turf I trust I am not insensible to the great and important necessity of religion; and that I will give no cause of reproach to the Society of which I now become a member, whilst I pursue an honorable and upright course in the pursuit of these amusements.

"And believing, as I do, that nothing tends more to the improvement of the moral condition of man than the general and universal dissemination of the Word of God, I cannot but wish success to your efforts and remain your Obt. Servant,

"Wm. C. Davis." 


\section{Meetings in Several Counties}

At the Mt. Pleasant race track in November, 1831, horses were run by Willis $\mathrm{H}$. Boddie, Mr. Coxe, Mr. Shegogg, H. Davis, George Elliott, Gen. R. Desha, Mr. Neely, Thomas Northern, - - Goodrum. Wesley Nixon was Secretary.

At the Woodlawn Course, $\mathrm{I} \frac{1}{2}$ miles from Clarksville, on the river, in September, 1831 , horses were run by Joseph Rudd, George B. Nelson, George W. Cheatham, Arthur Cotton, H. C. BeII and W. R. Gilbert.

The list of entries at the Hurricane Hill (Murfreesboro) meetings of 1831 and 1832 show that horses were run by B. Johnson, P. J. Burrus, Col. Robert Smith, Hollon Davis, O. Shelby, L. L. Davis, H. S. Wilkinson, R. Morgan, James Morton, John Crow, E. Sparks, J. B. Carter, W. Campbell, Mr. Gowen. G. S. Crockett was Secretary of the Jockey Club.

Lists of entries at Franklin in 1831 and 1832 show horses run by Beverly Reese, Gen. R. Desha, Haman Critz, S. D. Sharp, A. Rankin, Hollon Davis, W. B. Peebles, Joel G. Childress, George Elliott, N. Davis, John Crow, J. W. Camp, William Whitfreld, Daniel P. Perkins.

Lists of entries at the Clover Hill Course, Winchester, 1832, I833 show that horses were run by Maj. Richard Sharp, M. S. Wagner, O. C. Woods, M. J. Goodwin, Maj. John G. Bostick, Col. C. B. Hollingsworth, H. Bledsoe, R. H. Oliver, P. J. Curle, Maj. William Robinson, Turner B. Henley, J. A. Jenkins. E. Eaves was Secretary.

Lists of entries at Paris in 1832 and 1833 show that horses were run by J. C. Hamilton, Col. H. Harris, Col. W. B. Miller, John W. Cooke, Col. Henry Wright, Col. Robert Searcy, Gen. G. W. Terrill, Capt. Benjamin 
I34 Making the American Thoroughbred

Blythe, Dr. W. J. DeWitt, George W. Mix. F. T. Reid was Secretary.

Lists of entries at Jackson, 1830 and 1832 , show that horses were run by CoI. Wright, Maj. Martin, Col. Miller, Col. Cotton, Mr. Newsom, G. W. Cheatham, B. H. Slater, Dr. Thomas Rivers, Dr. W. E. Butler, Abner Pillow, R. Pryor.

Race meetings known to have been held, but from which no reports were made to The Spirit of the Times or The Turf Register, were those at Dresden, Paris and La Grange, in 1838 and at Petersburg in 1839 .

Having shown the character and performances of the leading horses in England, Virginia and Tennessee, from whom came the Tennessee horses of the gala-day period, it will be of interest to see how these scions of noble ancestors acquitted themselves on Tennessee tracks.

Following are official reports (condensed) of race meetings held in Tennessee, 1836-39 inclusive, as reported to The Spirit of the Times and The Turf Register.

The rule as to weights on tracks in Tennessee and other states to the south were usually the same as those adopted by the Nashville Jockey Club, as follows:

2-year-olds, 70 Ibs.; 3-year-olds, 86 Ibs.; 4-year-olds, Iоo Ibs.; 5-year-olds, I Iо lbs.; 6-year-olds, I 8 Ibs.; aged I 24 Ibs.; with an allowance of 3 lbs. to mares and geldings.

In the following reports, where a horse was run by one person and owned by another, the name of the owner is placed in parentheses after the name of the person making the entry.

\section{Hartsville Jockey Club}

At the Hartsville Jockey Club meeting, September, 1836 - Hartsville was then in Sumner County - there were four races, eighteen entries, by Capt. Jesse Haynie, Alex Yourie, Thomas Barry, Rich- 
ard Hall of Sumner, Col. Robert Smith of Murfreesboro, Col. R. Burford of Dixon Springs, John Coplinger and others.

Winners - (I) Sweepstake, 3-year-olds, mile heats, sub. "a bale of cotton," 8 subs. two running - Thomas Barry's gr. c. by Sir Henry Tonson; time not recorded but "pretty bang up."

(2) P. $\$ 430$, 3-mile heats, four running - FANNY BELL; time 6:426:13.

(3) P. \$250, 2-mile heats, two running - Yourie's b. c. by Bertrand, dam by Whip, 3 yrs.; time $4: 01 \frac{1}{2}-4: 01-4: 12$.

(4) P. \$200, mile heats, four running - Burford's ch. h. by Stockholder, out of Patty Puff by Pacolet, 5 yrs.; time I:54- I:57I: 59 .

At the Hartsville meeting, October, 1837 there were 13 entries owned by Richard A. Hall, Woods S. Miller, John Coplinger, Maj. W. L. Alexander, Thomas Barry, Watson \& Rutherford, Elliott \& Jackson, Cyrus Hart, James Jackson.

James Jackson's entry, SARAH BLADEN, "walked over" in a sweepstake, I3 entries, \$100 each, 2-mile heats. Elliott \& Jackson's ExoTIC by Leviathan, dam imp Refugee by Wanderer, 3 years, won a sweepstake, 12 subs. at $\$ 500$ each, h. f., three running, 2-mile heats.

Other winners were: Miller's HARPalyce, Foster Doak's (or Dake's) colt by Leviathan, dam by Conqueror, and Hall's gelding by Jefferson, dam by Conqueror.

\section{Gallatin Jockey Club}

In the years $1836-7-8-9$ the Gallatin Jockey Club held six meetings at one or more of which entries were run by W. W. Gift of Raleigh, North Carolina, John C. Beasley of Louisiana, Samuel Ragland, James Jackson, CoI. Robert Smith, Col. Thomas Watson of Franklin; Hon. A. J. DoneIson, David Burford, W. L. Alexander and A. Alexander of Smith or Sumner; Jo C. Guild, A. P. Yourie, Smith C. Franklin, Balie Peyton, Capt. Jesse Haynie, Maj. George A. Wyllie, Jesse Cage, G. W. Parker, B. F. Simpson, Charles Lewis, John Malone, Richard Hall, William Covington, C. CantreII, Arthur Cotton, Woods S. Miller, Yourie \& Head, Thomas Barry, George Elliott, Green Berry Williams, and W. E. Douglass, all of Sumner; John G. Turner, Thompson \& French, Head \& Smith, Ben Rutherford and W. H. Wilkinson. Head \& Smith's entry, DAY DREAM, by Luzborough, dam by Sir Archy, was owned by Hon. M. P. Gentry. 


\section{I36 Making the American Thorougbbred}

At the first meeting September, 1836, - four days, four races, there were 13 entries. The winners were Jesse Haynie's FANNY BELL; Beasley's othello by Leviathan, dam by Sir Archy; Jackson's waxlight by Leviathan, dam Pigeon by Pacolet, and Fanny bell again. Waxlight's race was a 4-mile heat race for J. C. P. \$750.

At the second meeting (Sept. 22-25 inclusive), 1837, there were five races and 19 entries. The winners were: Burford's crtizen, by Stockholder, dam Patty Puff; Jesse Cage's gray filly by Leviathan dam by Pacolet; Jesse Cage's THE PONEY; Ragland's QueEN oF DIAMONDS by Leviathan, dam by Sir Archy; and Ragland's oTHELlo by Leviathan, dam by Sir Archy. The highest purse, \$700, was won by The Poney, 3-mile heats; time 6:17-6:05 $6: 10$. There were five entries. The race was "severely contested, affording much sport; betting pretty severe after first heat." The race won by Othello was a 4 -mile race for a $\$ 600$ purse. Nature of soil "prohibited" good time. The Spirit gave this meeting a "write up" of 900 words.

At the third meeting, Sept. 17-22, 1838, there were seven races and 21 entries. The winners were Guild's DOCTOR DUNCAN (Iater JOHN malone); A. P. Yourie's filly by Crusader; Jesse Cage's QueEn of TRUMPs; James Jackson's Exotic; Thomas Watson's SHERIDAN (later osceolA), by Pacific dam by O. H. Perry; Thomas Watson's QUEen of TRUMPS; A. P. Yourie's ch. g. by Crusader, dam by Stockholder.

The first race, won by Queen of Trumps, was a sweepstake, 3year-olds, 19 subs. at $\$ 100$ each, $h$. f., five running, 2-mile heats; time 4:03-3:56. The Queen's second victory was a race of 4-mile heats for J. C. P. $\$ 600$; time 8: $12-8: 43$. Yourie's gelding ran a mile in $1: 58$, over a track 4 to 8 inches deep in dust after a four months' drouth.

At the fourth meeting, May 21-24, 1839, only ten horses ran. The winners were: Col. Jo C. Guild's John malone; Guild's CaroLINE MALONE, 3-year-olds, by Leviathan, dam by Sir Richard Tonson, out of the dam of Betsey Malone; George Elliott's воуD MCNAIRY, and Green Berry Williams' FLETA, by Leviathan, dam by Clay's Sir William. One-mile and 2-mile races only were run. The best heat, I : 49, was run by Caroline Malone, carrying 83 pounds.

At the fifth meeting, fall of 1839 , the winners were: Jesse Cage's maria williams, by Leviathan, dam by Napoleon; C. Cantrell's 
colt by Cantrell's Leviathan, dam by Bertrand; John G. Turner's BETSEY MILLER by Leviathan, dam by Oscar; . Ben Rutherford's colt by John Dawson, dam by Pacolet; Jesse Cage's Ragland, by Leviathan, dam by Stockholder, and his gray colt, MUD, by Leviathan, dam by Pacolet. The best mile heat, 1:54, was run by Betsey Miller, two years, carrying 67 pounds. Highest "take down" \$500.

Officers of the Gallatin Jockey Club in 1837 were: President, Jesse Cage; Vice-Presidents, James J. Blackmore and Eli Odum; Judges, Gen. William Hall (ex-Congressman and ex-Governor), Dr. Anderson and Eli Odum; Timers, Hugh Kirkman of Nashville, and Balie Peyton; Secretary, Thomas Barry.

Officers offrciating at the fall meeting, 1839, were: Jesse Cage, President; Thomas Barry, Secretary; Francis Wilson, Treasurer; Nicholas Davis of Alabama, Samuel Ragland of Alabama and Dr. Blackmore, Judges; Thomas Barry, Timer.

\section{Nashville Jockey Club}

Meeting, October, 1836 . Hinchin Petway, President; L. P. Cheatham, Secretary pro tem; Judges, James Gordon, Samuel J. Carter, E. H. Boardman, of Alabama, and L. P. Cheatham; Timers, Balie Peyton and Gen. Robert Desha. Six races; 26 entries; by Stockley Donelson, L. P. Cheatham, Arnold RusselI, George W. Cheatham, Thomas A. Pankey, Col. Robert Smith, John C. Beasley, James Jackson, John Crow. Track heavy.

Winners - (I) Sweepstake, 2-year-olds, one mile out, sub. $\$ 100$, h. f., four subs., two running - James Jackson's (George Elliott's) ch. SARAH BLADEN; time 2:00; won in a canter, competitor being amiss.

(2) P. $\$ 300$, ent. $\$ 120$ added, 2-mile heats, four running - James Jackson's WAXLIGHT; time 4:17-4:16 $\frac{1}{2}$.

(3) P. $\$ 500$, ent. $\$ 80$ added, 3-mile heats, two running - James Jackson's ExтıO, by Leviathan, dam White Feather, by Conqueror, 4 years; time 6:29-6:25. Hugh Carlin of Alexandria, Louisiana, then offered \$2,000 for Extio, which was declined.

(4) P. $\$ 700$, ent. $\$ 300$ added, 4 -mile heats, six running - James Jackson's (Kirkman \& Dickinson's) b. c. WACOusta, by Leviathan, dam by Tennessee Oscar, 4 years; time 8:13 - 8:12 - 8:24.

(5) Ladies' Purse $\$ 250$, ent. $\$ 210$ added, mile heats, best 3 in 5 , seven running - John C. Beasley's (Duke W. Sumner's) b. HoRTENSIA, 4 years; time $\mathrm{I}: 55-\mathrm{I}: 53-\mathrm{I}: 58-\mathrm{I}: 57$ I:) 54 . 


\section{I38 Making the American Thoroughbred}

(6) Sweepstake, 3-year-olds, mile heats, sub. $\$ 200$, h. f., three entries, two running - John C. Beasley's (Sam Ragland's) QuEEN OF DIAMONDS; time 1:55- I:53.

The Spirit of the Times gave this meeting 2,500 words. The most interesting feature was the hot fight between Wacousta, Fanny Bell and Othello, running in the order named.

At the meeting of the Nashville Club, Oct. 2-6, 1837, the officers were: President, H. Petway; Judges, H. Petway, John P. Hickman, L. P. Cheatham, Hon. Alex Barrow, Randall Ewing; Timers, Hon. Balie Peyton and Thomas Enbank Leefe, special Southern agent of The Spirit of the Times; Secretary, Hugh Kirkman; Patrol, Buck Maxey, R. P. Estes, S. W. Gilman, Aris Brown. Seven races, 34 entries; by George Elliott, Nicholas Davis, L. P. Cheatham, Andrew J. Donelson, John Donelson, Balie Peyton, William B. King, E. H. Boardman, W. J. Bass, G. Mason, James Jackson, L. Baller, Stephen Fenwick, A. B. Newsom, John C. Beasley, Stockley Donelson, W. H. Ghee, Thomas A. Pankey, A. L. Bingamon, of Mississippi, J. H. Bradfute, Samuel Ragland, A. V. and G. B. Long, of Kentucky, Randolph Skinner. Track muddy and heavy all week.

The Congressional stake, 3-year-olds, 14 subs. at $\$ 500$ each, h. f., 2-mile heats, three running, was won by George Elliott's SARAH BLADEN; time 4:13 - 4:15. Other winners were Newsom's 2-yearold filly (then unnamed, later BEESwING); J. H. Bradfute's victoria; Ragland's QUEEN of DIAMONDS; Bradfute's harkaway, by Merlin, dam Isabella by Sir Archy; Ragland's othello and G. B. Long's MARY JANE DAvis, by Stockholder, dam by Sir Archy. Queen of Diamonds' victory was in a race of 3-mile heats; time 6:21-6:20.

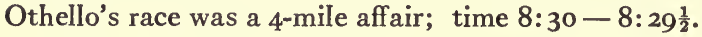

The Spirit of the Times gave this meeting a brilliant write-up of 3,000 words.

Nashville May meeting, 1838; six days; six races; 17 entries; by Guild \& Peyton, Col. George Elliott, A. J. Donelson, John Malone, S. W. Goodrum (Col. Thompson), F. Zollicoffer, Thomas Kirkman, James Jackson, A. Jackson, Robert Hayes, G. B. Williams, David Thompson, J. C. Guild, Thomas A. Pankey. AII the winners were bred or owned (or both bred and owned) in Sumner County. They were:

(I) Guild \& Peyton's Leviathan filly out of Black Sophia (undoubtedly BEESwING), 3 years, mile heats, best heat $1: 58$. 
(2) Guild's virginia overton, by Leviathan, dam by Virginian, 4 years, 2-mile heat race; best heat 4:12. She beat Exotic, another Leviathan (who later made a great reputation as a racer), the entry of James Jackson.

(3) John Malone's entry (Guild \& Peyton's) CATHERINE BARRY (Iater BEEswiNG), won a mile heat race in 2:05-2:04-2:06.

(4) Colonel Jesse Cage's THE PONEY, 4 years, was run as James Jackson's entry and won a 3-mile heat race in 6:44-7:03.

(5) G. B. Williams won a mile heat race with his Leviathan filly, dam by Sir William, in 2:02-2:07.

(6) The principal event of this meeting, the get of Leviathan vs. the get of Luzborough, is elsewhere described; post.

In August, 1838 the Nashville Club held a four days meeting at which were five races and 19 entries.

Nashville Fall Meeting, Sept. 29-Oct. 6, 1838: President pro tem, L. P. Cheatham; Secretary, Hugh Kirkman; Treasurer Thomas Gowdey; Judges, L. P. Cheatham, L. J. Polk, W. G. Harding; Distance Judges, William B. Gowen and R. Ewing; Patrol, H. Compton, R. P. Estes, Aris Brown, Thomas Alderson; Timers, Thomas Eubank Leefe and Henry Dickinson. Six races; 13 entries; by James Jackson, Davis \& Ragland, Col. William Wynn, of Virginia, W. J. Minor of Louisiana, Maj. W. R. Peyton, Thomas Barry, John Malone and William Potts. Except in two other events, described elsewhere, entries by Ragland \& Davis won all the races. Two of these five winners, ScIPIo and oTHELLO, were by Leviathan, two by Count Badger and one by Luzborough. Among the defeated were John Malone's entry, sheridan (Iater osceola), Colonel Wynn's victoria and his MARY WYNN. Victoria was by Eclipse, dam Isabella by Sir Archy; and Mary Wynn was by Eclipse, dam Flirtilla by Sir Archy. Track muddy all week.

At the Nashville Spring Meeting, 1839, beginning on May 7, and lasting five days, the winners were A. J. Donelson's colt by Mambrino, dam by Ratler; Jesse Cage's filly by Leviathan, dam by Napoleon; George Elliott's BOYD McNAIRY; also his three-year-old BIRMINGHAM; and Green Berry Williams' fleta. This last race, 3-mile heats, was run against Capt. H. M. Clay's GIRAFFe, by Luzborough. It was so close and exciting that the timers forgot to stop their watches. Owners of defeated horses, besides Clay, were Thomas Alderson, Mr. Kirkman, Arnold Russell, Mr. Peyton, Samuel Carter (Mr. Beal) 


\section{I40 Making the American Thorougbbred}

and W. H. Carroll. Thirteen horses in all; no purse exceeding $\$ 500$. The best mile was made by Birmingham $-1: 51 \frac{1}{2}$.

Nashville Jockey Club's First Fall Meeting, Sept. 19-22 and Oct. 5, 1839 .

Samuel Ragland of Alabama and H. Petway, Judges; L. P. Cheatham and John McNairy, Distance Judges; Nicholas Davis and T. E. Leefe, Timers; Hugh Kirkman, Secretary.

Five races, I7 entries; by Breathett \& Carroll, Samuel J. Carter, J. G. Shegogg of Columbia, J. H. White, J. C. Guild, Phil C. Shute, T. W. Gilman, Smith Criddle, D. Pitt, Davis \& RagIand, Robert Smith, A. P. Yourie and W. W. Gift.

Breathett's \& Carroll's three entries - two by Luzborough and one by Merlin - Davis \& Ragland's Luzborough filly, dam by Timoleon; J. C. Guild's Leviathan colt and S. J. Carter's filly by Russell's Houston were the winners. Best mile I :57.

Second Fall Meeting, Oct. 6-12, 1839.

President, L. P. Cheatham; Secretary, Hugh Kirkman; Judges, Gen. W. G. Harding, W. H. Boddie and H. Petway; Distance Judges, John McNairy and Thomas Alderson; Timers, Lucius J. Polk and Thomas E. Leefe. J. B. and S. J. Carter were now proprietors of the track, which was "fetlock deep and fast time impossible."

Eight races; 28 entries; by Charles Bosley, W. G. Harding, Wilson \& Nichol, Thomas Gale, W. W. Gift (J. Scott), L. Leavell, Ragland \& Davis, James Jackson, Balie Peyton, J. Anderson, G. W. Cheatham, H. Petway (James Hagan), L. P. Cheatham, Thomas Watson (L. Leavell), G. W. Cheatham (W. R. Peyton), L. J. Polk, Nicholas Davis, J. G. Shegogg, Col. Robert Smith, Jesse Cage, A. J. Donelson, L. P. Cheatham (James Long of Washington, D.C.).

(I) Charles Bosley's (W. G. Harding's) gr. c. Gamma, by Pacific, out of Madam Bosley by Sir Richard Tonson, won a 2-mile heat race in $4: 04-4: I I$.

(2) W. W. Gift's GOVERNOR POINDEXTER, by Leviathan, out of the dam of Giantess, won a 3-year old sweepstake worth $\$ 5,400$,

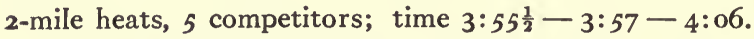

(3) George W. Cheatham's (Charles Lewis') EMILY SPEED, by Leviathan dam by Pacolet, won a 2-mile heat race in 3:58-3:56.

(4) Cheatham's MARY wYNN won a 3 -mile heat race, J. C. P. $\$ 600, \$ 30$ added, 3-mile heats; time 6:12-6:08-6:18.

(5) Jesse Cage's maria williams, by Leviathan, dam by Napo- 
leon, beat 5 competitors in a contest of mile heats, best 3 in 5; time 1:55- 1:53-1:53.

(6) Robert Smith's KINLOCK, aged, won a match race, one mile, in $1: 52 \frac{1}{2}$.

(7) N. Davis' Luzborough colt beat Shegogg's (S. J. Carter's) Bertrand filly in a 2-mile heat race; time 4:04-4:06.

(8) The main event of this meeting, the race between pIcton, OSCEOLA and BOYD MCNAIRY, is described elsewhere; post.

In the 3-mile heat race won by Mary Wynn, Thomas Watson's (L. L. Leavell's) Leviathan colt, James Jackson, won the second heat, after which he was sold for $\$ 3,000$. Mary had won the frrst heat and won the third and fourth.

\section{Franklin Jockey Club}

At one or more of the four meetings of The Franklin Jockey Club held, respectively, in Ocotber, 1837 , in May, 1838 , in the fall of 1838 and in October, 1839, entries were run by John Beach, John C. Irvine, David Pinkston, B. F. Nowlin, James H. Bradfute, Col. Robert Smith, Samuel Ragland, Thomas Watson (T. J. Wells), George W. Skinner, CoI. William Wynn, John A. Holland, A. Rodgers, Philip Shute, W. G. Harding, James Anderson, R. Skinner, Davis \& Ragland, Breathett and Carroll, Thomas M. Warren, J. L. Grainger.

At the first meeting, three days, three races, 8 entries, the winners were: Beach's bay colt by Malcolm, dam by Whip (then sold to Alabama); Smith's DANIEL o'conNell; Bradfute's victoria, 4 years, beat Ragland's QUEEN OF DIAMONDS, same age, in a race of 3-mile

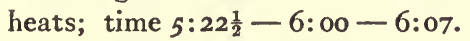

At the second meeting THE PONEY beat LEILA, by Luzborough, owned by Col. William Wynn, and BEESWING beat MARTHA WASHINGTON, by Sir Charles, out of Isabella by Sir Archy, owned by Colonel Wynn and run here as entry of George W. Skinner.

At the third meeting (1838) Col. William Wynn went out with MARY WYNN and VICTORIA and was given two "walk overs." In the other race his HARKAwAy, by Merlin, out of Isabella, left HAILSTоRм, by Stockholder, dam by Conqueror, "out in the cold"; time I : 59. Highest purse, $\$ 400$

At the fourth meeting, six days, six races, 23 entries, the winners were: Holland's colt by La Fayette, dam by Grey Tail; Skinner's 


\section{Making the American Thoroughbred}

POLLY PILlow, by Leviathan, dam by Sir Archy; Ragland \& Davis' SIR JOSEPH BANKS, by imp Luzborough, dam by Sir Archy; Robert Smith's (M. P. Gentry's) DAY DREAM; his PATSEY DAvis, by Count Badger, dam by Timoleon; and W. G. Harding's gamma. Patsey made the best time, mile heats - I:53-I:52-2:02. Largest purse, \$400. No 4-mile race was run.

The officers of the Club in 1837 were: President, Henry Baldwin, Jr.; Vice-President, James Swanson; Secretary, F. T. Reid; Treasurer, T. H. Handy; Judges, James Swanson, J. C. Southall, Henry Baldwin, Jr.; Timers, Hugh Kirkman, Samuel Ragland, Dr. S. S. Mayfield.

In 1839 the officers were: President, James Swanson; VicePresident, M. Puryear; Secretary, Thomas K. Handy; Treasurer, M. Doyle.

\section{Mr. Pleasant Jockey Club}

The race course of the Mt. Pleasant Jockey Club was on the property of W. H. Boddie and was managed by him. It was "delightfully situated in the centre of a dense wood contiguous to the town of Mt. Pleasant and was thirty feet over a mile."

At one or more of the three meetings held there, respectively, in October, 1836 , October, 1837 , May, 1838 , and May, 1839 , entries were run by W. H. Boddie, L. J. Polk, R. K. Polk, Nimrod Porter, William Pillow, James H. Webster, Henry Smith, F. Zollicoffer, all of Maury; Gen. J. A. Mabry of Knoxville; G. W. Parker of Sumner; Duke W. Sumner, Stockley Donelson, William McCrory, L. P. Cheatham of Davidson; Col. Robert Smith of Murfreesboro; Samuel Ragland, James Kirkman, James H. Bradfute and A. T. Nolen, and the following named, most of whom, probably, lived in Maury and Giles: J. Sutton, W. Lawhorn, Ben Greer, Thomas Heath, Dr. Roberts, G. W. Garrett, Thomas N. Williams, John S. Willis, Samuel MitchelI, J. G. G. Garrett, Thomas Heitt, N. G. Murphy, N. F. Smith, H. B. Porter, William Thomas, Thomas S. Smith, Wilkinson Barnes, S. NeweII, William G. Cage, John G. Keeble, D. L. Whitaker, Thomas E. Ridley, Thomas Goodrum, R. C. Whitesides.

At the frrst meeting referred to above Gen. Allen Brown was President; Lucius J. Polk, Vice-President; H. A. Miller, Secretary; Judges, William Pillow, L. J. Polk and Nimrod Porter; Timers,

L. P. Cheatham and J. J. Goodrum.

There were six races and 22 entries. 

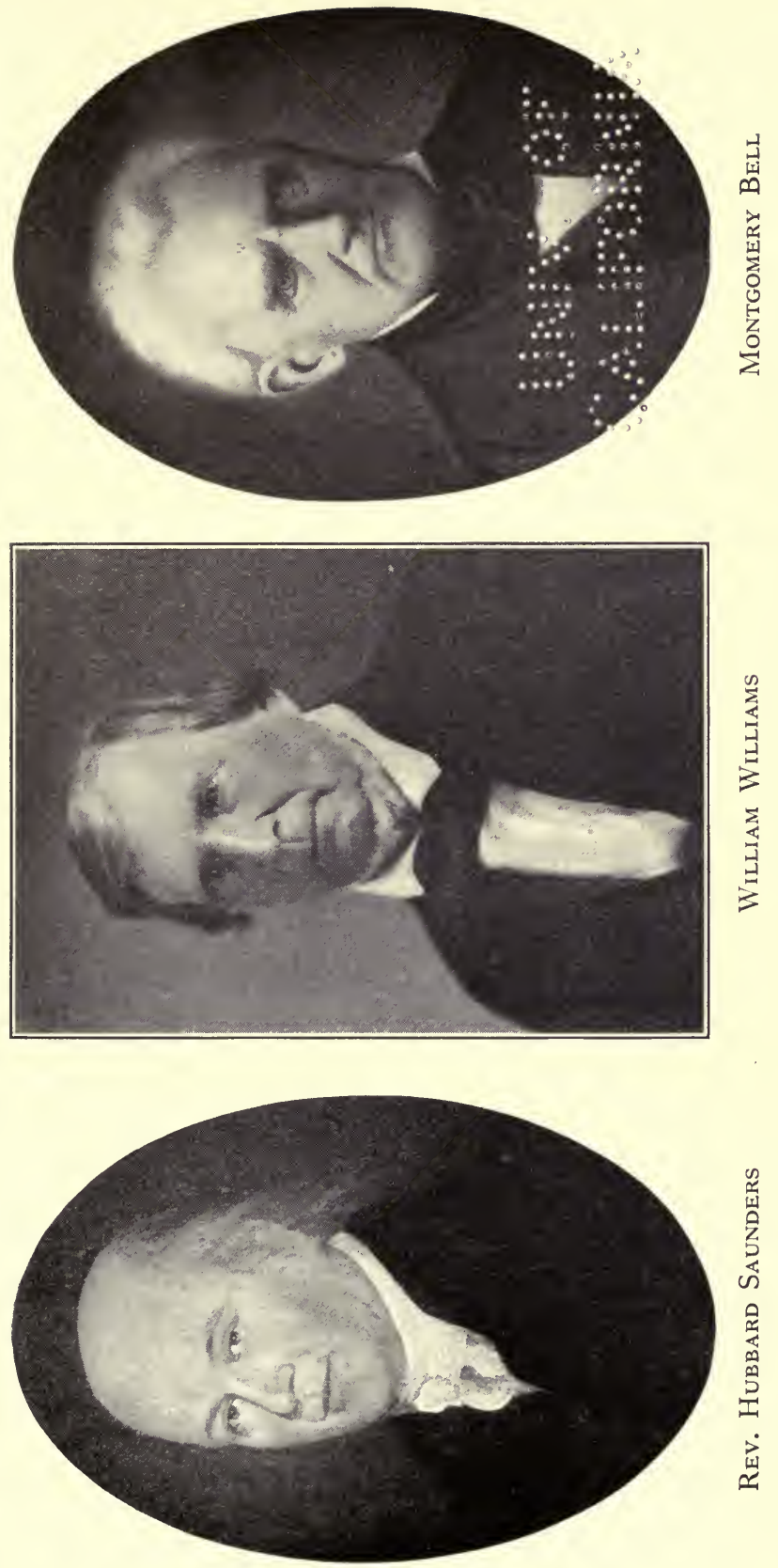

Winners: (1) Sweepstake, free for all, one mile out, sub. \$25, 4 subs. two running - Boddie's b. f. WHITE PINNER, by Stockholder, dam Pinner; time 2 :'06.

(2) P. $\$ 350$, ent. added, 4 entries - D. W. Sumner's hortensia; first heat $5: 57$.

(3) P. $\$ 200$, ent. $\$ 100$ added, 2-mile heats for 3-year-oIds, foaled and owned in Maury or Giles, with an inside stake of $\$ 100$ each, 4 entries, three running - L. J. Polk's ch. Lezinka, by Leviathan, dam Anvelina Smith; time 4:30-4:30.

"This race caused much excitement and the betting was pretty severe." Goodrum's gray maria, by Stockholder, dam by Pacolet, ran second; Henry Smith's Logan, by Pacific, dam by Stockholder, being distanced. Before the race Lezinka and Logan were each in turn the favorite. Polk had purchased Lezinka, when a yearling, from Henry Smith, for $\$ 500$.

(4) P. $\$ 250, \$ 100$ ent. added, mile heats best 3 in 5 , four running - Henry Smith's blacklegs, by Stockholder, dam by Pacolet, 4 years; time 2:01-2:04-2:11-2:11. G. W. Parker's Daniel o'CONNELl ran second, Ragland's QueEn of DIAMONDS, third. This was counted a great race.

(5) Sweepstake, 2-year-olds, one mile out, sub. $\$ 50$ h. f. and inside stake of $\$ 50$ each, seven subs., five running - William McCrory's NARCISSA PARRISH; time 2:04 $\frac{1}{2}$.

(6) Match, 2 miles out, \$10o a side, play or pay, W. Bromley's gr. ANThony wayne, by Jerry, dam by Sir Peter Teazle, 4 years, beat J. Sutton's ch. c. SELIM, by Talleyrand, dam by Little Billy, 4 years; time 4:50, with ease. The Spirit gave this meeting 1,500 words.

At the second meeting of four days Brown, Polk and Miller still held their positions as President, Vice-President and Secretary, respectively; Timers, Thomas Eubank Leefe and R. M. Wynne; Judges, John Dawson, Colonel Pillow and John Gordon; Patrole Judges, Henry Hunter, D. D. McFall, John W. Clanton and F. Zollicoffer; Distance Judges, J. H. Webster and Evan Young.

There were five races and 25 entries at this meeting. The winners were: Henry Smith's entry by Stockholder, dam by imp Eagle; John S. Willis' filly by Industry, dam by Ball's Florizel; Henry Smith's NARCISSA PARRISH; and his BEN MORgan, by Pacific, and Col. Robert Smith's daniel o'connell. Best mile heat I: 54 by Ben Morgan. O'Connell's race was of 3-mile heats and Narcissa Parrish's 


\section{I44 Making the American Thorougbbred}

of 2-mile heats. Prior to this, on October 12, at this track, NARcissA PARRISH won a sweepstake for 3-year-olds, 2-mile heats, time 3:573: $56-4: 10$.

At the third meeting of four days there were six races and 20 entries. At the fourth meeting of three days the track was fine and purses ranged from $\$ 500$ down. The winners were: Henry Smith's ALlen BRown, by Stockholder, dam by imp Eagle; R. C. Whiteside's filly, Allegra, by Stockholder, dam by Pacolet; and J. $\mathrm{H}$. Webster's colt, voltaire, by Leviathan, dam by Bertrand. Best mile heat was run in $\mathrm{I}: 52$ by Whiteside's 3-year-old filly, carrying 86 pounds. She won the $\$ 500$ P. P. sweepstake against four competitors. First heat $1: 56$.

\section{Clarksuille Jockey Club}

The officers of the Clarksville Jockey Club in 1837 were: William S. White, President; Thomas W. Barksdale, Vice-President; Reuben Pollard, Stephen Neblett and William S. White, Judges; M. D. Simmons and T. W. Barksdale, Distance Judges; C. Cruiseman and E. A. Davis, Timers; James C. Johnson, Secretary.

At one or both of the two meetings held respectively in September, 1837 and September, 1838 , entries were run by A. K. and L. L. LeavelI, Joshua EIder, Wilson Gilbert, Dr. John C. Ray, A. M. McLane, George W. Cheatham, William H. Irby, William L. Alexander of Hartsville, Reynolds Stark, H. H. Bryan, C. Cruiseman, Stephen Neblett, M. G. Gholson, John D. Everett and John Poindexter.

At the first meeting of two days there were two races and 9 entries. The winners were:

(I) P. \$400, ent. \$30, all ages, 2-mile heats, four contestants A. K. Leavell's general cheatham, by Stockholder, dam by Knowsley, 5 years; time 3:54-3:58.

(2) A. K. Leavell's Prince talleyrand, by Eclipse, dam by Duroc, 6 years; time 2:00- $-1: 59-1: 59-1: 58$.

At the second meeting of four days there were four races, 13 entries.

(I) Cheatham's MARY CRUiseman, by Woodpecker, 3 years, won a 2-mile heat race in 3:52-4:05.

(2) Alexander's Betsey watson, by Jefferson, dam by Sir Henry Tonson, aged, won the free for aIl sweepstakes, mile heats, best 3 in 5 , time $1: 50-1: 56-1: 53$. 


\section{Getting Their Money Back}

(3) Cruiseman's albert king, by Commodore Truxton, dam by Pacolet, won the 2-year-old sweepstake, $\$ 100$ subs. $h$. f. one mile, seven subs., two running; time $\mathrm{I}: 52$.

(4) Alexander's EudorA, by Jefferson, dam by Oscar, "walked over" for the citizens purse of $\$ 100$.

\section{Hurricane Hill (Murfreesboro) Meetings}

During the meeting held at Maj. John Bradley's race track, Hurricane Hill, near Murfreesboro, August 30 - Sept. 2, 1837, there were seven races and I9 entries: by Capt. John Crow, Col. Robert Smith, H. Hawse (Howse?), P. J. Burrus, O. W. Crockett, N. C. Dill, J. R. Head, of Mississippi, John Robinson, John Kennedy, R. Pattelo, Wilson Kerr. Purses ranged from $\$ 50$ to $\$ 300$. Track twelve feet more than a mile.

WinNers: (I) Crow's b. f. by Stockholder won the 3-year-old sweepstake, mile heats; time $\mathrm{I}: 57$ each heat.

(2) Smith's Sally McCall, by Leviathan, dam by Tennessee Oscar, 3 years, won a 2-mile heat race in 4:10-4:03.

(3) Crow's gr. h. by Washington, dam by Sir Archy, 6 years, won a 2-mile heat race in $4: 08-4: 00$.

(4) On the same day he won a mile race in $1: 52$ after which he was sold to J. R. Head for $\$ 3,500$.

$(5,6)$ In two separate mile heat contests Smith's s. h. vicksBurg (I:54) and Robinson's SIR RICHARD, dam by Sir Archy ( $1: 59$ ) were the winners.

(7) Pattelo's gr. m. by Waterloo, dam by Pacolet, 6 years, beat Kerr's b. f. by Tom Jefferson, dam by Stockholder, 4 years, in a single mile race; time 2:10.

At the August meeting, 1838 , at this track five races were run in dust 4 to 8 inches deep.

\section{McMinnville Race Meeting}

October 17-20, 1837; four races - entries by P. Hoodenpyle, B. C. Thomas, J. M. Bragg, F. A. Henry (Patre), A. Clark, J. Wilcher, W. R. Stewart, Thomas \& French. Mile and 2-mile heats were run. Best mile heat $I: 57$. Two-mile time 4:10-4:00. The winners were Hoodenpyle's colt by O'Kelly, dam by Black Sutton; Henry's (Patre's) colt by Kosciusko dam by Potomac; Henry's (Patre's) sportsman, by Brunswick, dam by Hamlintonian (or Hambletonian) and Henry's (J. H. Jenkins') Leviathan mare. In addition to these there were many trotting and saddle horse contests. 


\section{I46 Making the American Thorougbbred}

\section{Jackson Jockey Club}

The Jackson Jockey Club (Western District Central Course) had a meeting Sept. 26-Oct. I, inclusive, 1836 , and another meeting on the same dates in 1837 . Those who had entries in one or both of these meetings were W. W. Hurt, Dr. G. Bowles, Thomas Haile, Dr. Goodge, Mr. McFenner, John Timms, B. Lyons, H. Harris, B. Davidson, L. Coch, Mr. Sparks.

At the first meeting there were seven races and 25 entries. Harris, f. obeinA, by Telegraph, dam by Bagdad, 4 years, won a 4-mile heat race for a purse of $\$ 500$, time 8:17-8:30. She was then sold to an Indiana man for $\$ 3,250$.

Hurt's mıLo, by Benehan's Archy, dam by Royalist; Bowles' filly by Sir Charles, dam by Sir Alfred; Hurt's shylock, by Medley, dam by Powhatan, and his Twilight, by Sir Charles, dam by Aristotle, were other winners. A 3 -mile heat race for J. C. P. \$400 was won by Hurt's sterling, by Sir Charles, dam by Powhatan.

At the second meeting there were five races and 14 entries. The winners were Hurt's milo; Davidson's selima, by Sir Charles, dam by Sir Alfred; Coch's shylock, Hurt's sterling and Spark's (Bond's) MARY BOND, by Pacific, dam by Timoleon. STERLING's race was of 4-mile heats in the rain and mud; time 9:30.

\section{Bolivar Jockey Club}

October 12-13, 1836. Three races, 9 entries; by W. W. Hurt, B. Davidson, and another.

Winners: (I) P. $\$ 400$, ent. $\$ 40$ added, 3-mile heats, three running - Hurt's SHYLOCK; time $5: 55$.

(2) Prop's P. \$250, ent. \$30 added, 2-mile heats, two running Davidson's JANE PHILliPS, by Gohanna, dam by Wonder, 5 years; time $4: 00-4: 10$.

(3) Handicap Purse, $\$ 200$, ent. $\$ 10$ added, mile heats, four running - Hurt's TwiLight distanced the field, time $1: 51$.

\section{Somerville Race Meeting}

June $18-21,1838$. Four races.

(I) A. J. Henry's maria miller, by Stockholder, dam by Madison, 4 years, beat L. Coch's milo, 4 years, in a match race for $\$ 100$ a side; time 3:50-3:53. 
(2) Sweepstake 3-year-olds, 3 subs. at \$200 each - Henry's tom BENTON, by Telegraph, dam by Pacolet, beat L. Coch's Selim, by Saxe Weimer and Davidson \& Gowen's colt by Telegraph, dam by imp Buzzard; time $1: 54-1: 55^{\frac{1}{2}}$.

(3) Milo beat Davidson's hannibal, by O'Kelly, dam by Sir Charles, 3 years, in a 2-mile heat race for a $\$ 200$ purse.

(4) MARIA MILLER "walked over" a 3-mile heat, getting \$250 for her trouble.

\section{Memphis Jockey Club}

In 1836 , Oct. 31-Nov. 4, a race meeting was held at Memphis at which there were five races; Io entries owned by G. Bowles, Mr. Lyons, W. W. Hurt, Mr. Bumpass, Mr. Pitcher, and H. Harris. Among the races was a match, $\$ 1$, ooo a side between Hurt's KINLock, by Havoc, dam by Conqueror, 4 years, and Pitcher's ch. f. by Sir Charles, dam by Sir Alfred, 3 years; won by KINLock, time $1: 59-1: 56$.

(I) At the first meeting of the Memphis Jockey Club, Nov. 7-1 2, 1837, the judges each day were Maj. J. Cotton, President; Maj E. Hickman, Vice-President, and P. G. Gaines. No purse more th an \$500. Nineteen entries. The winner in the mile race was Y. N. Oliver's (of New Orleans) JOE KEARNEY, by Medley, out of Kate Kearney, by Sir Archy, 4 years. He beat DANIEL o'CONNELL and two others; time $1: 58-2: 01$.

(2) Oliver's MARY JONES, by imp Barefoot, dam by Eclipse, 4 years, won the 2-mile heat race; Robert Smith's SALLY McCALL second; L. Coch's MARY BOND, third; time $1: 58-2: 01$.

(3) The 3-mile race went to L. Coch's sterling, 6 years, time 6:23-6:20-6:20.

(4) William Burton's selima, by Sir Charles, dam by Sir Alfred, 4 years, won the 4-mile heat race; time 9:01 - 9:00.

(5) In the mile heat race, best 3 in 5, Oliver's MARY JONES won each heat; time 2:07-2:05-2:05. Last two races, track very muddy.

Owners of defeated horses were Col. Robert Smith, B. Davidson W. W. Hurt, L. Coch, John Frost of St. Lou is, Missouri, and J. R. McKee.

Another correspondent reported that Capt. Oliver had "found the soft place he was in search of." Also that this was "the first meeting of the Club" and the track "an entirely new one" by a never failing big spring. "The citizens and everybody appeared to be in the spirit of racing." 


\section{I48 Making the American Thoroughbred}

Memphis he considered the ideal "great central place of meeting of all horses from Alabama, Missouri, Kentucky, Tennessee, Illinois and all the lower country. Those who cannot travel here at aII seasons of the year by steam, have as good roads as need be, and not more than two hundred and forty miles to travel by land, which they can do at the rate of twenty miles per day, and lodge their horses comfortably every night. ... In traveling to the lower country this place lies in the route of all sportsmen passing with their horses. By next season they will find as good a track as ever was run over, with T. G. Johnson,-proprietor ... and here you will find as jolly a set of good fellows as ever you may meet with on any race track."

And so they are in 1916.

\section{Bean's Station and Red Bridge}

Reports of race meetings held at Bean's Station in 1836,1837 , and I839; and at Red Bridge, near Knoxville, in 1841 , show entries run by John McGhee, James Clark, John Blevins, Daniel Carmichael, Cox \& Morrison, Col. Samuel Bunch, William S. Geers, Daniel Green, Capt. John B. Proffit, James Scruggs, George Routledge, Mr. Guthrie, James M. Hord, James Powell, Capt. J. H. Anderson, Clark \& Bowen. In the list of entries is noticed, among others, the get of Cock of the Rock, Wild Bill, Leviathan, and Bertrand. At one meeting at Bean's Station, out of eleven horses that ran six were Leviathans and four of the six won. No purse exceeded $\$ 500$. A match race for $\$ 1,500$ a side was billed for Nov. I5, I 837 between Carmichael's LADY holston, by Bertrand, and Colonel Powell's ANN BARRow, by Thomas Barry's Cock of the Rock. James Scruggs was Secretary of the Bean's Station Club. 


\section{STORIES OF EIGHT FAMOUS RACES}





\section{AMERICAN ECLIPSE vS. HENRY}

The first North and South match, which started a long series of sectional contests, grew out of the fact that American Eclipse was without a rival in the North and Sir Charles without a rival in the South.

On Nov. 20, 1822, C. W. Van Ranst, of New York, owner of American Eclipse, and James J. Harrison of Brunswick County, Virginia, owner of Sir Charles, appeared at the Washington, D.C., course to run a match race, 4-mile heats, with these horses, for $\$ 10,000$ a side. Harrison paid forfeit, $\$ 5,000$, because Sir Charles had met with an accident that disabled him for a 4-mile contest; and then he proposed a race of one 4-mile heat for $\$ 1,500$. This race was run. Sir Charles broke down.

Later in the same day CoI. William R. Johnson, of Virginia, who had witnessed Sir Charles' defeat, offered to produce a horse on the last Tuesday in May, I823, to run 4-mile heats against Eclipse over the Union Course, Long Island, for $\$ 20,000$ a side, $\$ 3,000$ forfeit. An agreement to this effect was consummated at once; it was virtually Eclipse against the world. This contest soon assumed the phase of a North and South affair - the first of the many matches of that name and character that enlivened the annals of American racing.

From the time the news of the match reached the far interior the South felt sure of victory, due largely to confidence in Col. Johnson's well known skill and ability in the management of contests of this sort. 


\section{I52 Making the American Thorougbbred}

His father, before him, was on the turf, and if the son was not born in a manger he certainly grew up in the stable.

When quite young he was entrusted with his father's horses and started one contrary to instructions. Upon being reprimanded he challenged his father to a match race to prove that the horse he had started was better than the one he had been told to start. After this race the elder Johnson announced that William was "keener" than he was and surrendered the management of all the horses to him. That the father, himself, was a man of keen judgment was proved by the subsequent career of the son.

About I804-05 Col. Johnson was partner in a match race run by Peacemaker and Ball's Florizel, and trained Peacemaker. He was defeated but he afterward won Iargely with Sir Archy, Pacolet, Sir HaI, Vanity, Reality, Sally Walker, Trifle, Andrew, Boston, Bonnets O’Blue and many others.

"In I808," said a writer in The Spirit of the Times in 1839, "with an inferior colt, True Blue, Col. Johnson won the great Fairfield stake, beating Sir Archy, Wrangler Palafox and Virginius - all, subsequently, of the highest distinction. In 1809 and 1810 he won greatly with Sir Archy and Pacolet, beating every competitor; and in the latter year, with Maria, an inferior nag to the others, won the famed 20-mile race at Fairfield, beating Duroc, Sir Alfred and others. Shortly after this, Tuckahoe, by Ball's Florizel, became the great race horse of the day, first in Virginia and then in Maryland. In I8I6 the Colonel beat him in Washington with Vanity, having brought $\$ 30,000$ to stake on the event. His brilliant career has since been continued with Reality. But from I823, the time of the Eclipse match, his exploits on a 

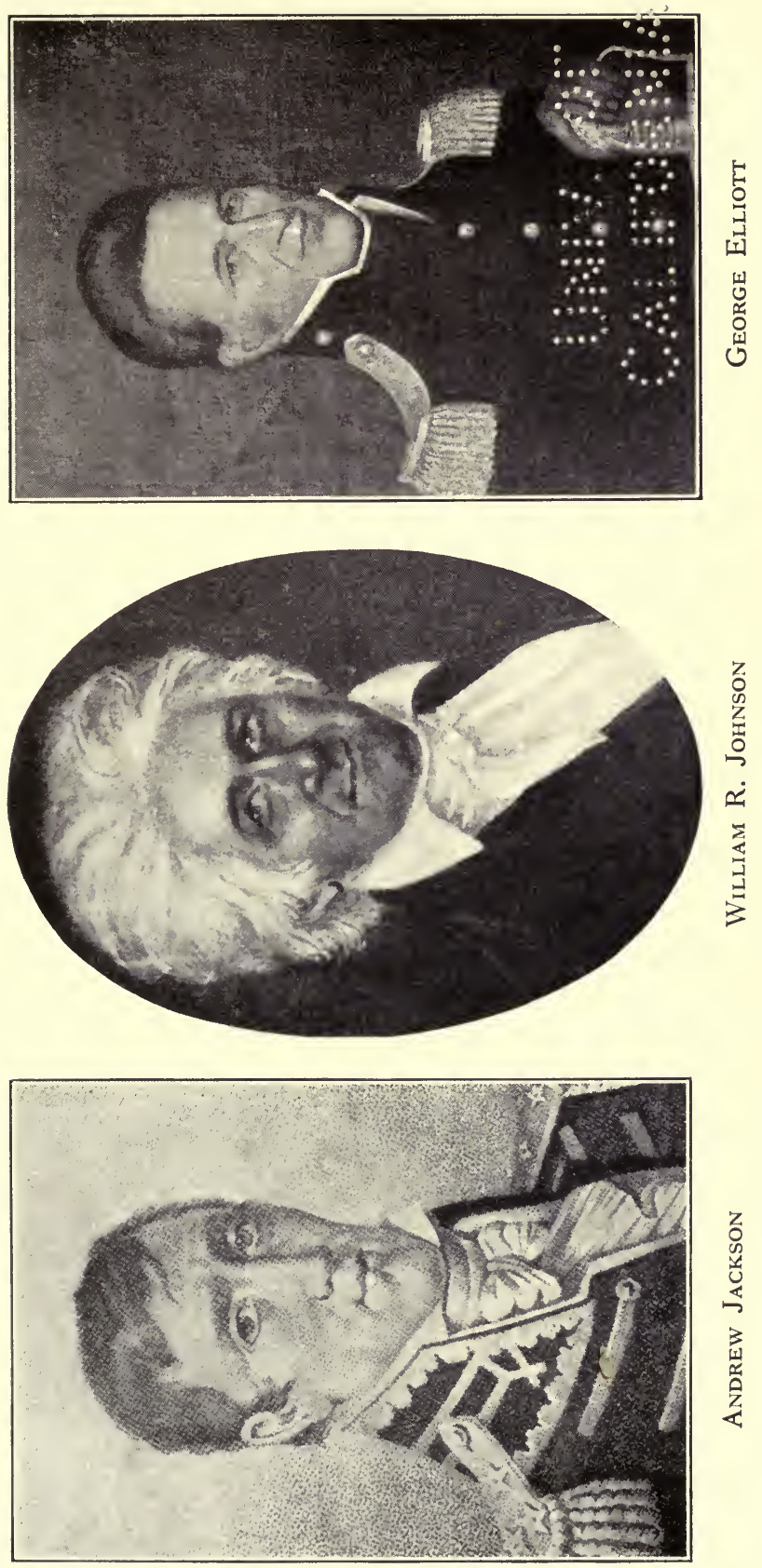

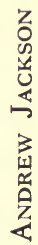




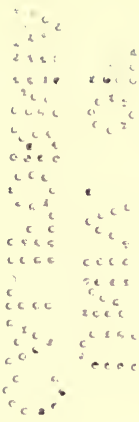


wider theatre may be dated. If ever defeated - from that he was sure to reap advantage; like another Frederick his genius shone brightest after a repulse. He may have rode and trained his own horses. You will recollect the Duke of Bedford rode Dragon ${ }^{1}$ when he beat Sir J. Lade's Cliffden, rode by the latter. Both horses came to the United States."

In the 30 North and South matches and sweepstakes run between 1823 and I834, John C. Stevens and W. R. Johnson were usually the largest stockholders, when stakes were divided, and each usually owned the entries of their respective sections or managed the contests. Of the 30 races the South won 17 . The aggregate sum at issue in the 30 contests was about $\$ 120,000$, and it was regarded as singular that a balance of only $\$ 6,000$ stood to the credit of the South. This amount, $\$ 120,000$, was exclusive of bets and Jockey Club purses. The latter, in which the South was generally victorious, would increase the sum to her credit by $\$ 12,000$ to $\$ 15,000$. The week before the frrst Peytona-Fashion race was run, in 1845 , The Spirit reported that in large stakes, and in matches for sums ranging between $\$ 1,000$ and $\$ 5,000$, the North seemed to have the best of it, but the South had made a drawn game of big events. More of this in another story.

Some men engaged in the breeding and raising of horses for pastime; Johnson made it his vocation, his avocation and his vacation. Being a man of good judgment, having a just regard for the importance of system and the care of details, and in love with his business, success was inevitable. He accumulated a large fortune and for 30 years or longer he was known as "the Napoleon of the Turf." A visitor to his home, "Oaklands," near Moody's

${ }^{1}$ Dragon, as shown, stood in Tennessee. 


\section{I54 Making the American Thorougbbred}

Tavern, wrote that everything about his place, the movements of servants, etc., showed the master's executive ability and love of order, and clocklike regularity in the daily routine.

For several terms Col. Johnson was a highly respected member of the Virginia legislature, was a Whig candidate for Presidential elector, and for several years was among gubernatorial and congressional probabilities. According to the writer just quoted, Johnson prided himself "upon never having read a book through, like General Jackson. Yet the former I regard as a man of much the best mind of the two - better fitted to make a President."

John Randolph had great confidence in Johnson's genius as a horseman and in his judgment of congressional as well as Jockey Club races, and frequently sought his advice concerning party policies and his own individual interests. As evidence of his esteem Randolph willed Johnson $\$ 25,000$ and made him one of the executors of his estate, which, by the way, included about Ioo thoroughbred horses at the time of Randolph's death. Following the precedent set by Randolph, Abner Robinson, a wealthy horseman of Richmond, Virginia, who died in 1843, made Col. Johnson one of the executors of his estate and willed him $\$ 25,000$.

Under the agreement between Van Ranst and Johnson the South, as stated, had the privilege of naming the contestant against Eclipse. Five horses were put in training at Bristol, Pennsylvania - John Richards, Betsey Richards, Henry, Washington and Flying Childers. John Richards was Johnson's first choice and Henry, or Betsey Richards, second. Washington fell amiss, John Richards was lamed and both were left at Bristol. With the other 
three, Johnson arrived at the Union Course a week before the time set for the race. Only after repeated trials did the Southern turfmen decide to run Henry in preference to Betsey Richards. This, according to accounts printed at the time. Another story, printed by the Baltimore Cbronicle I4 years later (not entirely contradictory of the first), was to the effect that in a private trial in New Jersey Henry gave evidence of such high speed it was determined to distance Eclipse and make but one heat of the race. Subsequent events tend to support this statement.

Henry was foaled June 17, 1819, "the property of Lemuel Long of near Halifax, N.C." " 1 His dam was by imp Diomed and his grandam Belloni by Bellair; - by son of imp Fearnought; - by imp Valiant; - by imp Janus; - by imp Jolly Roger. In the Diomed line, therefore, Eclipse and Henry were closer kin than third cousins and each was a great-grandson of imp Medley.

The day the race was run was fine. At noon, it was said, few people were left in New York City outside of Bridewell and the hospitals. The straight stretch in front of the grand stand (nearly a mile) was lined with carriages four and five deep. Trees and fences "groaned with their loads of human beings." Sixty thousand ${ }^{2}$

1 Halifax, North Carolina, is within a very short distance of the Northampton County line. In 1826 , one Lemuel Long, born in 1799 , moved from Northampton County, North Carolina, to Mt. Pleasant, Maury County, Tennessee. Dr. S. C. Long, of Mt. Pleasant, informs the writer that his father, Lemuel Long, was the man that bred Henry.

2 The record attendance at baseball games in the United States was in I9I 2 when, in the series of eight games between New York and Boston for the world's championship, the aggregate number of admissions was $25 \mathrm{I}, 90 \mathrm{I}$ - an average of $3 \mathrm{I}, 487$. Only 60,000 people witnessed "Gil" Anderson's record breaking automobile run in New York in October, 1915. 


\section{I56 Making the American Thorougbbred}

people, many of whom were from the South, were on the ground. But Col. William R. Johnson was not.

"Where, where was Roderick then!

One blast upon his bugle-horn

Were worth a thousand men."

Indeed, the entire 60,000 could have been spared better than he - from the Southern standpoint. An overdose of lobsters had put the actual management of the race upon others. Besides the stake of $\$ 20,000, \$ 200,000$ was bet on the result.

Though not yet four years old Henry was required to carry 108 pounds. Eclipse, nine years old, carried 126 pounds. In the first heat William Crafts rode Eclipse and a Virginia boy named John Walden rode Henry. Crafts wore a crimson jacket and cap and Walden a sky blue jacket and cap.

Henry took the lead at the start, was soon three lengths ahead, and kept that distance ahead up to the last quarter of the fourth mile, running all the time under a strong pull, neither whip nor spur being used at any time. Eclipse was terribly punished and pushed to his utmost but never got any closer than one length to Henry; thus they came under the wire; time $7: 37 \frac{1}{2}$, which remained the record for many years. Henry had run the four miles in shorter time than his managers had expected.

Samuel Purdy, who had frequently ridden Eclipse and who understood him better than anyone else, was then engaged as a housebuilder in New York City. A misunderstanding had resulted in his not being chosen as Eclipse's jockey for this contest. Purdy, feeling that he would be needed, attended the race, wearing his jockey suit under his citizens clothes and with cap and spurs in his pocket. After Crafts had demonstrated to everyone 
his inability to manage Eclipse, Purdy was chosen. $\mathrm{He}$ was 49 years of age, a man of high integrity and honor, a popular favorite and famed for his grace and self-possession in the saddle. When he appeared for the second heat the Northerners went wild with joy.

Henry took the inside and kept the lead, followed by Eclipse. Purdy saw that his only chance was to make it a contest of strength and endurance and for nearly three miles he drove Henry nearly at the top of his speed, about 20 feet ahead, with little variation. Near the end of the third mile Purdy made his run and Eclipse's nose about reached Henry's tail as they entered the fourth mile where there was a turn, or sweep, in the track. On this move Purdy risked everything; it was a desperate case and he boldly took a desperate chance. He made a frght for the inside and before they reached the centre of the turn Eclipse lapped Henry about head and girth. A little more than halfway round the sweep the horses were a dead lap, Eclipse on the inside; when three-fourths round Eclipse's quarter covered Henry's head and neck. As they finished the bend and entered upon the straight run along the back part of the course Eclipse was clear and ahead. By strong persuasion he gained inch by inch during the remaining three-quarters of a mile and came in about two lengths ahead. As the horses passed down the home stretch, according to a writer who was present, "the long and loud applause sent forth by the Eclipse party exceeded all description; it seemed to roll along the track as the horses advanced, resembling the loud and re-iterated shout of contending armies," Time 7:49.

"The time of their second heat," according to an experienced critic, "proved that Henry had been overworked and that the bottom of Eclipse, joined to his great recuperative powers, was too much for his young competitor." 


\section{I58 Making the American Thorougbbred}

In the third heat Walden was supplanted as Henry's rider by Arthur Taylor, later famed as Boston's trainer for three and a half years, and "long a rider equalled by few and surpassed by none." . At the start, quoting from the same eye-witness, ${ }^{1}$ "Purdy took the lead and pushed Eclipse from the score, and indeed the whole four miles, applying the whip and spur incessantly, evidently resolved to give Henry no respite, but to cause him, if determined to trail, to employ all his speed and strength without keeping anything in reserve for the run in." Henry continued trailing until about 60 rods from home in the Iast mile. "Here, being about five yards behind, he made a dash and ran up to Eclipse so far as to cover his quarter, or haunch, with his head, and for a moment had the appearance of going past; he made a severe struggle for about two hundred yards when he again fell to the rear and gave up the contest. ... In the last heat Henry carried I io Ibs., being two pounds over his proper weight; it not being possible to bring Arthur Taylor to ride less, and although a small horse, and wanting twenty days of being four years old, he made the greatest run ever witnessed in America." Time 8:24. The time for each of the twelve miles averaged $\mathrm{I}: 59$. In the opinion of many experts "the amazing swiftness of Henry lost him the race."

To Col. Johnson's absence many of the Southerners attributed Henry's defeat. Their unshaken confidence in Henry's superiority was shown by the challenge issued by Johnson a few days later to run Henry against Eclipse, at Washington, the following Fall, 4-mile heats, \$20,000 to $\$ 50,000$ a side, each party being allowed the privilege of substitution from horses of their respective sections. In declining this challenge, for himself and others in the 1 C. R. Colden. 
most gentlemanly manner possible, John C. Stevens, of New York, closed as follows:

"For Mr. Van Ranst I answer that he owes it to the Association who have so confidently supported him, to the State at large, who have felt and expressed so much interest in his success, and to himself as a man not totally divested of feeling, never, on any consideration, to risk the life or reputation of the noble animal whose generous and almost incredible exertions have gained for the North so signal a victory, and for himself such well-earned and never-failing renown."

What the "Eclipse party" thought of Henry was evidenced by his purchase soon after his defeat and his removal to New York, where he stood for many years and did much to improve the stock of that state. He died in Hanover County, Virginia, in I831. Besides Post Boy, he got Decatur who won a $\$ 10,000$ match race from Fanny Wyatt, 4-mile heats, at Washington, D.C., in 1838; time 7:45. Decatur's dam was Ostrich by American Eclipse.

And so it came about that both Henry and Eclipse won the esteem of all sections by their performances, and, through many worthy descendants, linked their names and their fame inseparably in the list of the great horses of America.

Immediately after the adjournment of Congress on March 3, 1823, according to Garland's biography of John Randolph, the sage of Roanoke, "hurried off to Virginia and spent some days with his friend, William R. Johnson, in Chesterfield, who was then in high training for the great match race between the North and the South. The exercise and excitement of mind in anticipation of his favorite sport produced an evident change in Mr. Randolph's 


\section{I6o Making the American Thoroughbred}

health; it was much improved; he slept better than he had for ten years.

“" To that night,' says he, 'spent on a shuck mattress in a little garret room at Chesterfield Court-house, Sunday, March the 9th, I 823, I look back with delight. It was a stormy night. The windows clattered, and William R. Johnson got up several times to try and put a stop to the noise, by thrusting a glove between the loose sashes. I heard the noise; I even heard him; but it did not disturb me. I enjoyed a sweet nap of eight hours, during which, he said, he never heard me breathe. N.B. I had fasted all day, and supped (which I have not done since) on a soft egg and a bit of biscuit. My feelings next day were as new and delightful as those of any bride the day after her nuptials, and the impression (on memory at least) as strong.'

"He was present (as most lovers of the turf were) at the celebrated race between Eclipse and Henry, on the Long Island Course, in the month of May. He stood in a very conspicuous place on the stand during the race, surrounded by gentlemen of the North and the South; and he evidently was very confident of the success of Henry. But after the result, to him so unexpected, and while the thousands of spectators were vociferously applauding the successful rider (Purdy), Mr. Randolph gave vent to his great disappointment by exclaiming to those around him in his most satirical tone:

" "Well, gentlemen, it is a lucky thing for the country that the President of the United States is not elected by acclamation, else Mr. Purdy would be our next President, beyond a doubt.'"

Hon. Rufus King, of New York, and Col. William Wynn, of Virginia, were together at the race, and the editor (then or Iater) of the New York Express was near them. 
Randolph "was excited to an astonishing degree, as almost every other person present was," wrote the Express editor many years later. "When Henry had beaten Eclipse in the first heat, and had come in ahead on both the first and second rounds of the second, it was a despairing moment and all was breathless silence. Even in a crowd where more than a hundred thousand persons were spectators, the slightest noise could be heard, and at this particular juncture when the horses were hidden by a knoIl, Mr. Randolph cried out in his shrill voice, to Colonel Wynn, of Virginia, who stood in a better position 'Whose horse is ahead now, Colonel Wynn?' to which a reply was given in a stentorian voice, 'Mr. Randolph, Eclipse has passed Henry' - 'Then,' cried out Mr. R., 'we have lost the race, by God.' These emphatic words were heard by the multitude, and deafening shouts rent the air."

Randolph believed that Henry was the best horse, and, it was said, could never endure the sight of a lobster because, as he stated, "it was a supper of lobsters, not Eclipse, that beat us. If Johnson had been there the day would have been ours. As it is - Eclipse will gain more fame for beating such a horse as Henry than for winning the race."

But on the authority of A. T. Nolen, of Williamson County, Tennessee, it may be stated that Johnson, more conservative than Randolph, did not place all the responsibility for Henry's defeat on the supper of lobsters. In advertising O'Kelly, by Eclipse, to stand at his place in I836, Nolen said that after Johnson had failed to put down Eclipse and had failed later to put down his colts, "he turned about and bought several of Eclipse's best sons, such as Lance, Goliah, O'Kelly, Vertumnus, etc., and, to cap the climax, bought half of the veteran, Eclipse. Being a general of great sagacity and skill he 


\section{I62 Making the American Thorougbbred}

turned to gathering in his own hands the armour of warfare with which he had been scourged."

At a session of Congress, some time after the EclipseHenry race, the exigencies of the hour bring Randolph to his feet to roam at large through a wide range of subjects. He has bouquets for some persons, thorns for others; biting sarcasm for the people of the North as a whole. His long service and many speeches have not diminished the attractiveness of his unique personality or lessened interest in what he has to say upon any subjct. Among his associates in Congress - as had been the case among strangers at the Eclipse-Henry race-his emphatic, shrill-voiced scintillations always fall on appreciative ears. The scene at the Union Course flashes across his mind. He pauses a moment for a starting point while House and galleries lean toward him in perfect silence, wondering what he will say next - eager to catch every word. And this is the gold, unalloyed with the sting of defeat, with which they are rewarded:

"Mr. Speaker: I pass from the great men, as they are pleased to call themselves, of the Northern tribes - and digressing even further from the particular object of my speech, call the attention of the House to a man, who knows, in his vocation, no superior. He has not, Sir, 'split the ears of the groundlings' in this hall, a panorama of human life, or, in the theatre, the mock representative of man's follies and woman's weakness, drawn down the applause of the galleries, by 'tearing a passion to pieces,' as we see and hear every day, or rather night, in the play houses of this country. No, Sir. The man of whom I speak, was the last and only hope of the North in a struggle between it and the South, where pride and skill were at stake. I was opposed to him; I joined in the general wish 
of every true son of the South that his great knowledge of his vocation should fail him. But we were all doomed to sad disappointment. I believe we lost by the absence on the occasion of one of Virginia's best sons, who had a 'rascally ague' at the time. - I speak, Sir, of Samuel Purdy, the rider of Eclipse! Had you witnessed the exultation of the South when Henry came out ahead, on the first heat of that memorable contest, you might form some idea of the consternation which prevailed in our ranks when it was announced that Samuel Purdy was to ride Eclipse the next heat. The breathless anxiety and silence with which we eyed him, as he threw his leg over the noble animal, were only broken by the murmuring applause with which the adverse party greeted his appearance. The skill of the Virginia rider was undoubted, but it required something more than human to compete successfully with Samuel Purdy. The horses went off from the score, and as all the world knows, Eclipse won. The renown of the performance of that day will go down with the history of civilized society, and transmit the name of Samuel Purdy as the most skillful of jockeys to the latest posterity." 


\section{POST BOY vs. JOHN BASCOMBE}

What Southern horse was fit to go against Post Boy?

That was the question that focused public attention as the time drew near for the great North and South match of 1836 .

The date set for the race was May, 31; up to April 12 the horse that could give Post Boy a run for his money had not yet appeared in the South.

For the race with Eclipse CoI. Johnson had put several horses in training in the Virginia winter. Now, hot weather had come to the Southern racing kingdom and found it still without a horse.

The gravity of the situation was intensified by the brilliant performances of Post Boy in his 4-year-old form, the previous year, when he won six races without losing a heat and secured a place in popular esteem second only to that held by Eclipse a few years before. Two of these races were of two miles, and four of four miles. On Nov. 6, he ran two 4-mile heats under a pull, yet ran each in 7:52 - the best 4-mile heats of that year. In all of these races, which were run in New York and New Jersey, Post Boy contended with the best horses of the East, and some from Maryland and Virginia. The "Old Napoleon," himself, had one of his best in the race in which Post Boy made the record 4-mile time of the year.

This North and South match was to be of 4-mile heats for $\$ 5,000$ a side, half-forfeit. Each side had the privilege 
of naming a contestant at the post. As of one voice the North, at the close of the season in November, 1835, named Post Boy as their champion and awaited impatiently the time when his prowess would win for him the championship of the entire Union.

To be caught hors de combat was very trying on Southern spirit and sportsmanship; but what hurt still more was the feeling of confidence at the North, and the knowledge that this confidence was well based. Then it was, when the South was sore depressed, that a new star came into the racing firmament where least expected and pointed the way to a creditable contest, if not to victory.

And what of this new star?

In the frrst place his dam was foaled in Williamson County, Tennessee. Col. James Gray Jones, of Williamson, owned a Kentucky bred mare by imp Buzzard a grandson, through Woodpecker, of King Herod and the great-grandsire of Glencoe. This mare Col. Jones bred to Pacolet when that historic horse stood at J. W. Clay's, in what is now South Nashville. Grey Goose, the produce, after being run by Col. Jones in Tennessee, was sold to John Connolly, of near Huntsville, Ala., who, in 1830 , bred her to Bertrand, the produce being a colt.

Soon after this colt was foaled a Methodist Camp Meeting was held on Connolly's plantation. The chief orator of the meeting - as his name was spelled by Connolly - was Rev. John Bascom-be. Connolly attended the services, formed a warm admiration for the preacher and entertained him in his home. By way of expressing his esteem, Connolly asked permission to name one of his colts John Bascombe, and this pleasure was not denied him.

Of all his colts of that year John Bascombe was Connolly's favorite. 


\section{I66 Making the American Thorougbbred}

In the best racers in England at that time the BuzzardDiomed cross was the most prominent, and in this country Woodpecker (by Bertrand), winner of every race he ran, was a forcible illustration of its worth. The success of this intermixture of blood was doubtless the basic reason for Connolly's good opinion of John Bascombe. But the colt's early performances did not come up to Connolly's expectations and he was sold in a lot of four or five others, including Bill Austin (by Bertrand dam by Timoleon), to Connolly's son-in-law, Maj. John Blevins, of South Alabama. Maj. Blevins, finding that Bascombe could beat Bill Austin in all their trials, sold the latter to CoI. John CroweIl, of Fort Mitchell, Alabama, who put him in charge of M. L. Hammond to be trained.

Hammond had trained for President Jackson and his private Secretary Maj. A. J. Donelson, and if he had not learned his system from "Old Hickory" he certainly agreed with the President of the United States as to the necessity of severe treatment in training race horses. Hammond's methods were condemned by many but he brought results where others failed. It was so with both Bill Austin and John Bascombe. In a race between these two horses, at Mt. Meigs, Alabama, November 24, I835, Austin defeated Bascombe, and Maj. Blevins, miffed at his defeat, let Bascombe go for a small sum to join Bill Austin in Col. Crowell's stable. Hammond then put Bascombe through the "third degree" and brought him into the winning class, on two 3-mile occasions.

Over in South Carolina, in the stable of Col. Wade Hampton, at this time, was a famous racer, Argyle (by Mon's Tonson, dam Thistle by Ogle's Oscar), owned jointly by Col. Hampton and Col. W. R. Johnson, and another, and valued at $\$ 15,000$. Just for pastime Argyle's owners proposed to Col. Crowell to put $\$ 17,000$ 


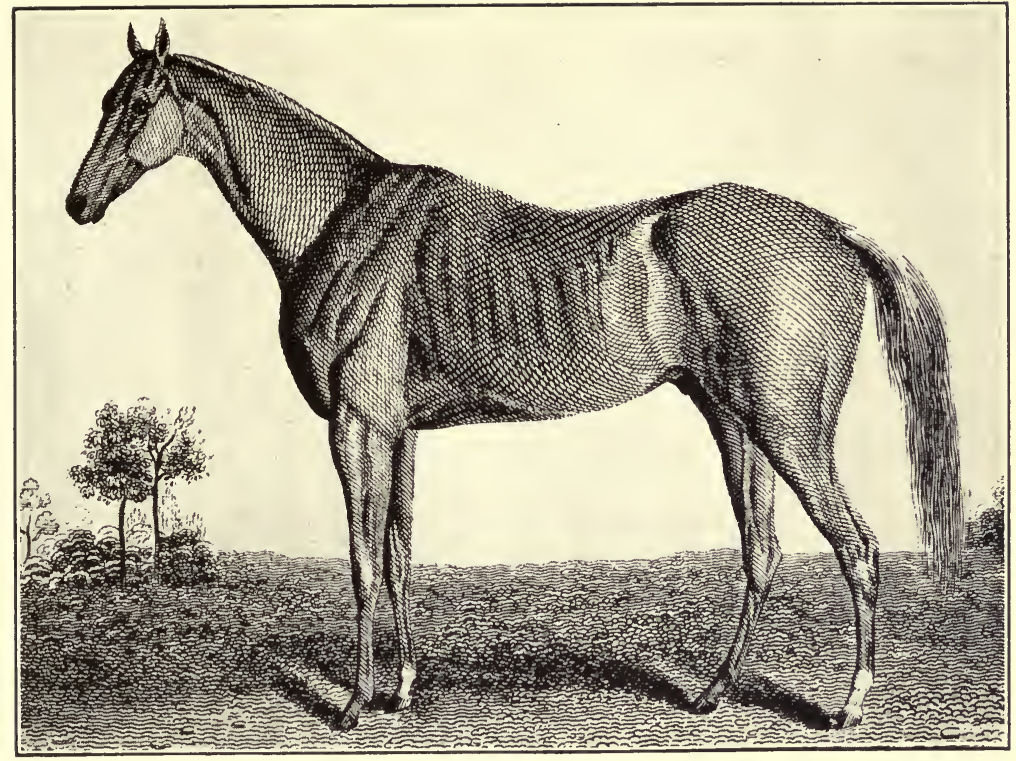

John Bascombe

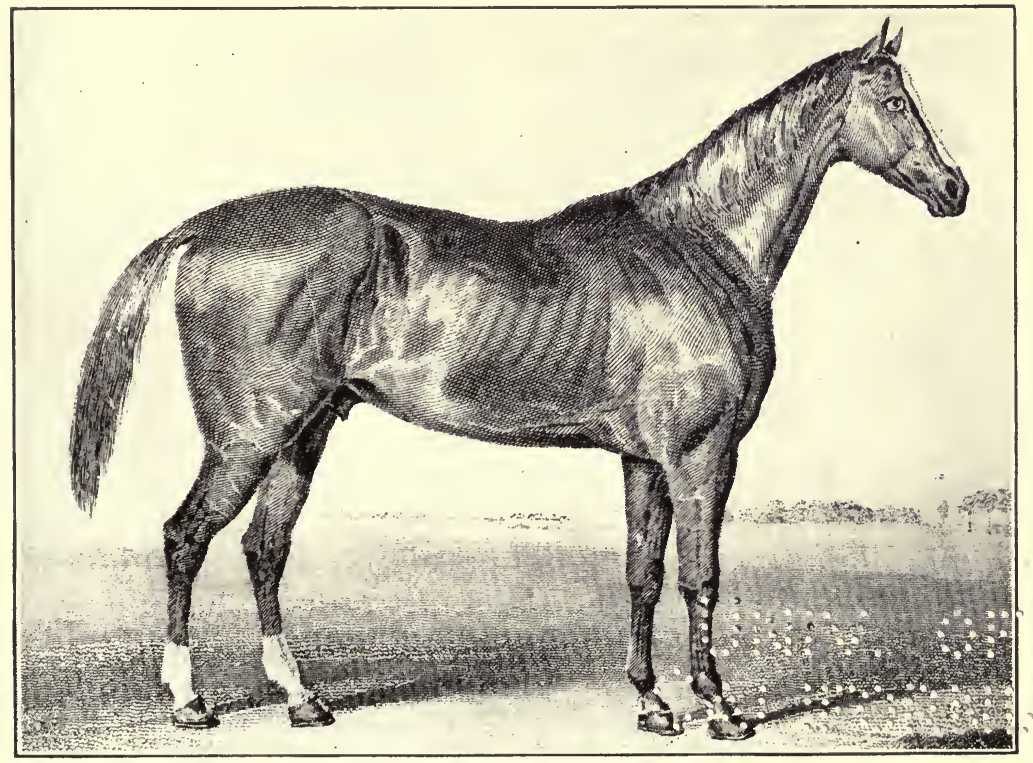


4 
on Argyle against $\$ 15,000$ on the choice of Bill Austin, Lady Nashville, Bolivia or John Bascombe, in a little 4mile heat affair between friends. ${ }^{1}$

This challenge was accepted and the race set for April 12, 1836 at Augusta, Georgia.

In training for this match Bill Austin and Bolivia broke down and Lady Nashville fell amiss. To Col. Crowell it was a ground hog case-John Bascombe or forfeit and, what was worse, a back down. To John Bascombe it was Opportunity knocking loudly at his stable door. The hearty response he made showed he was prepared for the call. Carrying 102 pounds he distanced Argyle in the first heat; time $7: 44$.

A new light had come into the South.

That everybody felt that way about it is clearly shown by what followed.

CoI. Crowell, as soon as the race was over, tendered John Bascombe to Col. W. R. Johnson to contend with Post Boy, and the offer was promptly accepted.

Simultaneously with the news of Bascombe's discovery the word went northward that Post Boy would have a competitor worthy of his fame.

Bascombe, who had been in hard training since the

1 Bolivia was by Gen. Andrew Jackson's Bolivar and Lady Nashville was by Stockholder. Both mares had been foaled in Davidson County, Tennessee, as the property of Maj. A. J. Donelson, Bolivia being owned subsequently by President Jackson. After both mares had been trained in the White House stables by Hammond they were sold to Col. Crowell. In a letter to Stockley Donelson written in Washington, July 24, 1835, A. J. Donelson said he had received a letter "from Col. Crowell of Georgia in which he says of Lady Nashville: 'she can run under a hard press the first and second heat of four miles' and he believes the third without giving back one inch and I am satisfied if Johnson had her he would not give her for two Trifles. Crowell has refused three thousand for this mare and the same price for Bolivia." 


\section{I68 Making the American Thoroughbred}

previous August, took up the line of march at once for Long Island. His route took him through the land where his two grandsires, Sir Archy and Pacolet, had brought renown to Col. Johnson; and it must have been with a feeling of considerable pleasure that the OId Napoleon looked upon Bascombe and called him good.

At Newmarket, Virginia, Bascombe stopped for a little recuperation and proceeded from there with horses of Col. Johnson's stable. Most of the journey was made on foot and under many hardships incident to flood and mud.

Post Boy was bred by Nelson Lloyd, of Lloyd's Neck, Queen's County, Long Island, and was foaled May 5, 1831. He was out of Garland, by Duroc. Garland's dam was by Hambletonian (by imp Messenger) and her grandam was Miller's Damsel (by imp Messenger); so in Post Boy was united the blood of Sir Archy and the Eclipse family, excellent crosses, as shown in the careers of Shark, Black Maria, Mingo, Alice Grey, Henry Archy and others.

Post Boy was fifteen hands and two inches high, dark chestnut, one hind foot white. He was well put together for hardihood and carrying weight, his greatest and almost only defects being a short trunk and too much rotundity.

In April, I834 (Robert) Tillotson \& Gouveneur, of New York, paid $\$ 700$ for Post Boy, and thereafter he ran in Tillotson's stable. Gouveneur sold his interest to Tillotson in the fall of 1836 .

Bascombe had not as many victories to his credit as Post Boy, but he had made better time at Augusta than Post Boy had ever made. Carrying I I4 pounds, in a race with Post Boy, of the same age and carrying the same weight, what would be the result? 


\section{Post Boy vs. Jobn Bascombe}

The fact that there was very little betting before or during the race showed that conservative minds considered the horses about evenly matched, an opinion subsequently confirmed. The track was not in the best condition and a strong wind blew from the northeast, so the best time was not anticipated.

Post Boy's popularity at the North, and the sudden leap into fame by the hitherto unknown John Bascombe, drew to the Union Course the largest crowd that had assembled there since the Eclipse-Henry race.

Bascombe was a light chestnut, with one forefoot and one hind foot white. As a whole, his form indicated speed, but neither great endurance nor ability to carry weight. So said some critics. Others thought his makeup indicated speed, endurance and strength. The accuracy of these widely divergent opinions was soon to be tested.

When the Southern champion, after an unprecedented journey, was stripped for action, his high spirits, perfect condition and game appearance won for his trainer the most Iavish praise. Col. Johnson's favorite jockey, Willis, who had ridden Argyle at Augusta, mounted Bascombe. Gilbert W. Patrick, who Iater rode Boston successfully for three years, and who, still later, rode Lexington when he made a new 4-mile record at New Orleans, mounted Post Boy.

Post Boy had the pole. Bascombe took the outer edge of the track to make a straight run for the lead. At the first tap of the drum they got away, making play from the start. Willis collared Post Boy, was soon a length in front, and as they entered the back stretch Bascombe took the track and was never headed. As they swung round the turn Post Boy let out a link and the pace improved, though Bascombe still led his saddle girth. As they 


\section{Making the American Thoroughbred}

passed the Judges' stand Bascombe widened the gap a length. Willis' strategy now became evident.

"Bascombe made play on each straight stretch, and led so far as to give his antagonist no chance in rounding the semi-circles, where Willis, hugging the pole, held him up invariably, obliging Post Boy to make so wide a swerve in order to pass, that by the time the horses were neck and neck, they had cleared the turn, when he (Willis) would immediately take his place in front. Willis' riding evinced the utmost nicety of judgment as to the powers of the nonpareil he so gracefully bestrode. He found that his horse had the foot of Post Boy, and the only fear was of his endurance. But he made his race safe by striding away at a tell-tale pace around the back stretch, on the north bend of which he had reason to fear Post Boy might prove dangerous. The first mile was run in 2:02; in the second Post Boy having got limber, and finding he had an ugly customer, went at him in earnest, and the pace grew very much better, as he locked him. With little change of position, they ran thus the whole of the second mile in $1: 56$. Now Willis was to do or die. He knew that on the fourth mile, Post Boy would make bis brush, and he had heard of that before - it was a caution but the 'Metbodist Priest' under him was ' $a$ sin to Crockett!' Post Boy collared him as they passed the gate on the third mile, when Willis at once took a pull at his horse, and holding him well together, kept him at his work. The pace was killing - but 'calm as a summer's morning' Willis was winning his race out of the fire. This mile, the third, was run in I : 54 and it gave Bascombe the race. Post Boy had lapped him aII the way, and the result was that when they reached the north corner he had not a run left; while Willis, who was going the pace without distress, drew a little upon his horse, and finally won the heat in 7:49 with something to spare, in hand, Post Boy pulling up within the distance pole and walking in."

Just before the bugle sounded for the second heat announcement was made from the Judges' stand that C. W. Van Ranst would present, as a meed of honor to the victor of the contest, the saddle worn by American Eclipse "in the first great strife between Northern and Southern horses, together with his bridle, rider's cap, 
jacket and spurs - the glorious trophy to remain a perpetual prize for all similar trials of speed and bottom."

Neither Bascombe nor Post Boy had seemed distressed by the first heat and both came up fresh for the second.

After some trouble in starting they got away neck and neck, Post Boy on the outside, and went to the end of the first mile in two minutes, without apparent effort.

"On passing the stand, Post Boy received a hint to increase his stride, and Willis, wide awake, but cool, let go his horse a little by the head. The pace mended at once, Bascombe still leading by a throat Iatch, and Willis keeping him there. This mile and the third were both run in $1: 56$, the horses locked all tbe way, and so close together that the knees of their jockeys were knocking against each other - both, too, going the pace, as the time shows, at a flight of speed.

"So beautiful and spirited a contest was never witnessed in America.

"On sweeping round the first curve of the last mile the gallant little fellow on Post Boy set-to in sporting style. He had long been finessing to get a pull at his horse, to bottle him up for a desperate brusb. But Willis gave him no respite - he knew both horses like a book and his judgment of pace told him, that to make the race a safety Post Boy must be allowed no let up to recover his wind. Bascombe was creeping ahead gradually as they got on to the back side, when but one chance remaining for Post Boy, little Gil seized upon it, determined to do or die. Catching his horse by the head, the rowels were laid in up to the shank, claret was tapped, and his whip-hand at work. Under persuasions like these Post Boy drew out a head and neck in front, but Bascombe maintained his stride steadily as they went along the great sweep on the back side, the pace getting more and more severe as they neared the hill. Leaning forward as they came to the dangerous corner, Willis grazed his glossy side with the spur, and the noble animal under him justified his training by instantly recovering his position, and they came down to the last turn at a slashing rate, running a dead-lock the whole way. The pace now grew still more severe, and the shout that went up from thousands as they dashed round upon the straight run home, told of hopes and fears, how delightful to a sportsman! Here Post Boy made his final struggle - heels and hands were 


\section{I72 Making the American Thorougbbred}

busy with him - little Gil is a punisher, and he did wonders - but the go-along had been taken out of his horse by the artiste on Bascombe, who now clapped in both gaffs and gave him a push a la Cbifney, that sent the phenomenon from Alabama past the winning post a clear length ahead, midst the waving of hats, and kerchiefs, and enthusiastic cheers that made the welkin ring for miles around."

The following is the record of the time of each mile, taken from the timer of the race as it was noted at the stand:

First Heat - Ist mile 2:2; 2 d mile 1 : 56 ; 3 d mile 1 : 54 ; 4 th mile $1: 57$. Total $7: 49$.

Second heat - Ist mile 2:00; 2 d mile $1: 56$; $3 \mathrm{~d}$ mile I : $56 ; 4$ th mile $1: 59 \frac{1}{2}$. Total $7: 51 \frac{1}{2}$.

Amidst the approving shouts of the multitude, Willis, as Bascombe's rider, was formally presented with the trophy offered by Van Ranst. "Let its glorious associations," wrote Editor Porter, "ne'er be sullied by those unworthy of the trust, but endure through all time the memento of never fading victories achieved by the high mettled racer and his honest rider. John Bascombe is worthy of his laurels, his title and descent. The South has beat us fairly and honestly on our own ground. We give them joy of their victory. The trophy now goes from us, but how long shall the South retain it?"

Both Willis and Hammond received their dues in the way of compliments. "The South may boast of another Bascombe," said Editor Porter, "but we shall Iook in vain for another trainer like M. L. Hammond, or a second Frank Buckle in the person of Willis. The latter's riding was a theme of general praise; the grace with which he sat his horse, not less than the perfect coolness, judgment and skill with which he managed him would have done credit to Sam Chifney or Jem Robinson in their primest days. Well has he won his honors - may he wear them long." 
"Arthur Taylor" continued Porter, "is a great creature in his line of life and has long been deemed at the head of his profession; but he must be content to bear a rival near the throne. For out of twenty races in which Col. Crowell's horses have been named this year, Hammond has won eighteen, winning for the veteran, in purses and matches, the sum of thirty thousand dollars."

Bascombe's victory took the Northern people by surprise, and the excitement and feeling of chagrin over the defeat of their favorite was slow in dying out. They believed Post Boy was the better horse and that his defeat was due to a change of trainers. John Buckley, who had charge of him for this match, had been out of the training business for two years, and, it was urged, did not know Post Boy's temper and constitution. There was, therefore, a strong desire for another test. At the club dinner where the wine was red, there were many banters and acceptances, from which reports spread that Bascombe's friends were afraid of another trial. This led to a proposition by Col. Crowell for another race for a sum not less than $\$ 10,000$. This banter was not taken. Later a challenge was issued to the world for a match race for $\$ 20,000$ a side. This banter not being taken within the time specified, Bascombe, after running and winning one more race, went into the stud at $\$ 100$, at the Hampton Course, near Augusta. Col. Crowell had combined his stable with that of John G. Winter, of Augusta, as a result of trouble with the Indians at Fort Mitchell, Alabama.

During the ten days following his defeat by Bascombe, Post Boy won two 4-mile heat races, in one of which he ran the fourth mile in $\mathrm{I}: 47$; but in the Fall campaign, he Iost two races to Col. W. R. Johnson's Atalanta and paid $\$ 1,000$ forfeit to Mingo. Up to this time he had run sixteen races and won nine; in three years netting $\$ 12,700$. 
I74 Making the American Thoroughbred

As the property of Robert Tillotson, Post Boy stood at James Holmes, Murfreesboro, Tennessee, 1838-1841; service \$roo. He covered 62 mares in 1838 . In 1839 Tillotson declined an offer of $\$ 10,000$ for him. He lived to a great age and died at Dixon, Illinois. The likeness of John Bascombe is reproduced from a steel print made at the time of his races with Argyle and Post Boy. 


\section{ANGORA vs. RODOLPH}

"Gallatin, Tenn., Dec. 22, 1835.

"To the Editor of the Baltimore Sport Magazine:

"I will run my mare, Angora, by imp Leviathan, out of Thomas Barry's mare, Patty Puff (by the renowned stallion, old Pacolet, out of the famous brood mare Rosey Clack) 4-mile heats against any horse, mare or gelding in the world for $\$ 5,000$ a side $h$. f. The race to be run on the first Thursday in October next over the Nashville Course; or I will run her the same distance against any horse, mare, or gelding in Kentucky for the same amount on any half way course on the same day - the rules of the Central Course of Baltimore to govern the race. If either of the above propositions is accepted the nag must be named and a forfeit of $\$ 2,500$ deposited in the Union Bank at Nashville on or before the first day of April next.

"Robert Desha."

Attracted by the tide of emigration to the Southwest, Robert Desha left Pennsylvania, lived awhile in Kentucky and finally located in 1782 about four miles east of the present site of Gallatin. Among his children, accompanying him on this journey, were two sons: Joseph, then I4 years of age and Robert, a few years younger. Joseph Desha later returned to Kentucky, where he became a legislator, Congressman and Governor. In the war of I812, he was a Major General. Robert, the younger brother, remained in Sumner, served in the war of 1812 as Captain and Brigade Major, and represented his district in Congress two terms, I827-3I. He married Nellie Shelby, daughter of David Shelby and granddaughter of Anthony Bledsoe, and lived at Spencer's Choice in a residence built by his father-in-law, in 1798 . 


\section{I76 Making the American Thoroughbred}

Some years after the events recorded in this narrative, "General" Desha - as he was called - moved to Mobile, Alabama. Since then his name as the breeder and owner of one of the best race "nags" of his time has been entirely lost to memory, and he is now best known as an ancestor of several New York multi-millionaires and a sprig or two of English "nobility" - so-called. ${ }^{1}$

Gen. Desha's challenge added greatly to the feeling of expectancy that pervaded Spencer's Choice and the country round, during the Christmas festivities that followed its writing. It was several times printed as an advertisement in one of the Nashville papers and, doubtless, in Kentucky papers. Anyhow, in the course of a few weeks, it came to the eye of Capt. Sidney Burbridge of Frankfort, then at the head of Kentucky breeders and trainers, who lost no time in removing Gen. Desha's fear that no one would accept his challenge. After some public correspondence, running through several weeks, during which time counter propositions were made, it was finally agreed that the race should take place on Sept. 21, 1836, at Oakland Course, Louisville, the stake and distance being as named by Desha.

Burbridge met Desha's challenge with Rodolph, 5 years old, bred by Charles Buford, of Scott County, Kentucky, and sold by him to Burbridge and Dickey. Rodolph was by Archy-out-of-Transport, son of Sir Archy; his dam by Haxall's Moses, grandam by Cook's Whip (by imp Saltram, dam by Herod) and great grandam by Craig's Alfred, son of imp Medley. Rodolph was $15 \frac{1}{2}$ hands high, bay, with a coat like satin; his hind feet white to the upper pastern joints; his forehead fine, his head, neck, shoulder and back "almost perfection"; a

1 For statements about the Desha family Cisco's "Historic Sumner County" is relied upon. 

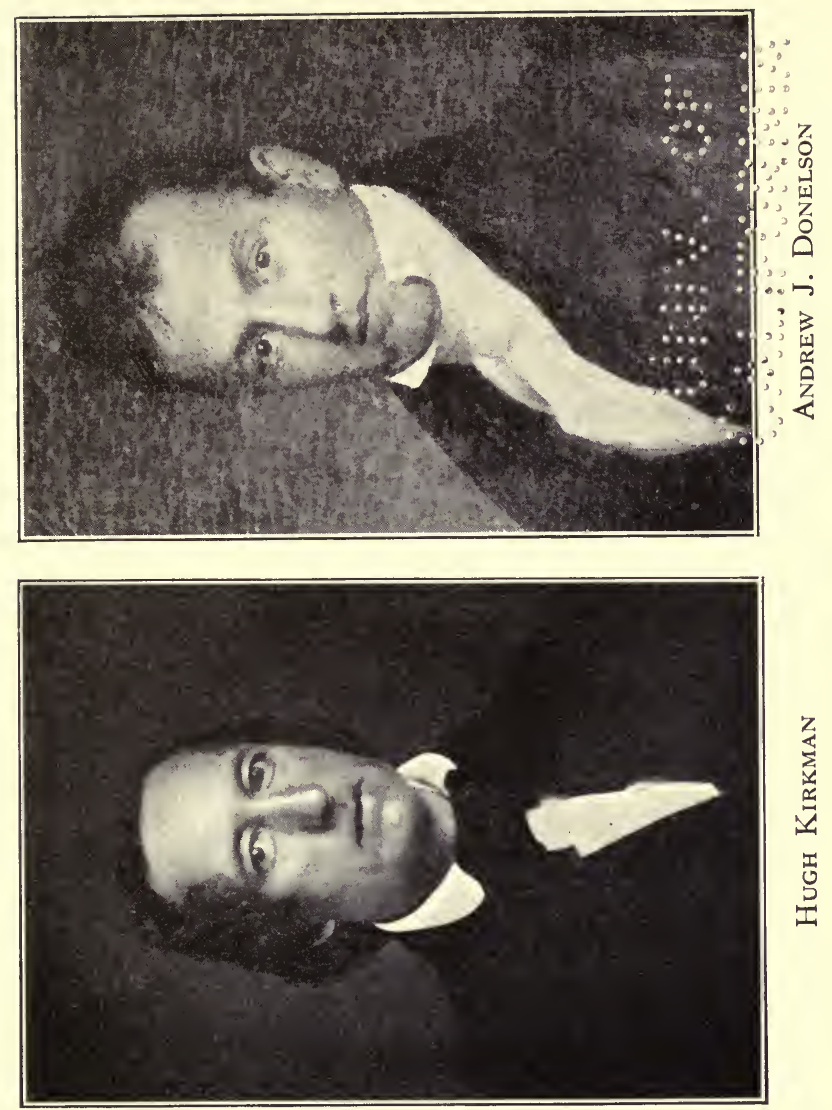

资

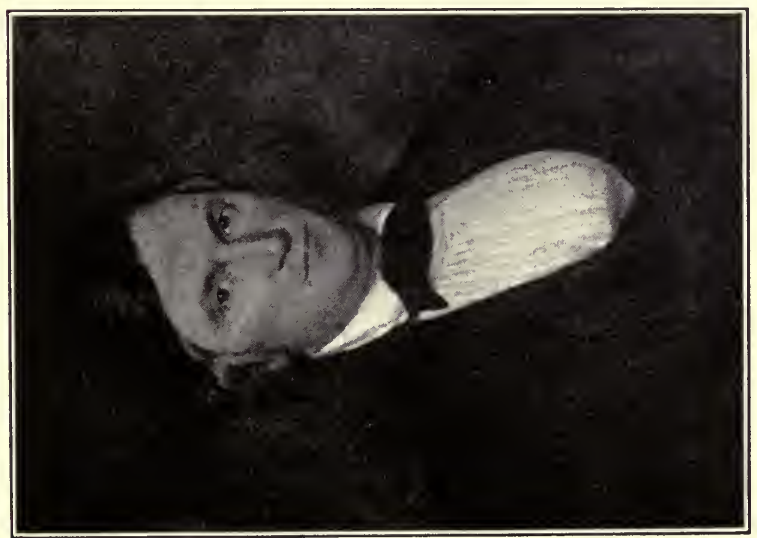

م. 


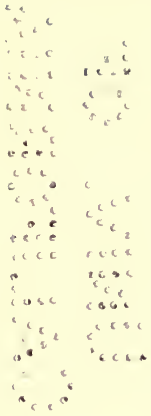


clean set of limbs; homely, but muscular, quarters; light bodied; his forearm "uncommonly long, thick and strong."

Under the training and management of Burbridge Rodolph had run six races and won all of them. These were a 2-mile heat race, three 3-mile heat races and two 4-mile heat races. Over the Oakland Course in the spring of 1835 , in a 3-mile heat race, he was credited by his owners as having made the best time ever made "west of the mountains" - first heat $5: 54$; second heat $5: 48$. Kentuckians thought him a great 4-miler, but the Editor of The Spirit, who was in no sense prejudiced against Kentucky, could not see that Rodolph's best time entitled him to be so classed. After Desha's challenge had been accepted Rodolph served his full quota of 40 mares. Angora was 4 years old, $15 \frac{1}{2}$ hands high, a chestnut without white. Her head was finely shaped and well set on a long neck; her forelegs set wide apart, but came to the ground evenly and in line. Her thighs and arms were light but muscular; her cannon bones very long; across the loin and through the brisket she was."very fine," her shoulders broad and oblique. She was bred by Gen. Desha and was trained for this race by Green Berry Williams.

Under the agreement Angora was to carry 97 pounds and Rodolph 118 pounds.

The only questions that could possibly have been involved in this contest were the merits of the horses, the relative merits of the Archy and Leviathan blood, and the skill of the respective trainers and riders. But here, as in many political campaigns, the real question became of secondary importance, and the contest assumed the phase of a great fight between Kentucky and Tennessee for imaginary supremacy in the racing world of "The West." 


\section{I78 Making the American Thorougbbred}

As such contest it excited great interest among the people of the two states named and, also, among devotees of the turf throughout the Union. The extent of the popular interest is indicated by the reports of events at Louisville where enthusiasts commenced to gather two weeks before the day set for the fates of Kentucky and Tennessee. Louisville at the time had about I5,000 population, all told.

"The town is crowded with strangers from all parts of the Union," wrote The Spirit of the Times correspondent on September 20. "The stages and steamboats still continue to bring in crowds. All the hotels are actually crammed. It would do you good to witness the anxious looks after the first bell rings for dinner, all are so eager to make the first rush. I presume the excitement in this part of the world to be much greater than it was in New York during the conflict between Bascombe and Post Boy."

"Perhaps no race in the Union ever excited greater or more intense interest," said a Louisville Journal correspondent.

"The excitement produced by this contest," said The Lexington Observer and Reporter, "has never before been equaled in the West."

On the 19th both Angora and Rodolph were exhibited to "a large assemblage of gentlemen." "They were both admired and reflected great credit upon their trainers, Mr. Williams and Mr. S. Burbridge. Several bets were made even, though Angora is the favorite." So wrote The Spirit man the day before the race was run.

Ten thousand people saw the race. The "magnates of the land, friend and foe in the political arena, met on the turf in cordial friendship." Among the spectators were Col. A. L. Bingaman and Gov. Poindexter, of Mississippi; Judge Porter of Louisiana; Gen. Desha, Col. George 
Elliott and Gen. J. A. Mabry, of Tennessee. Balie Peyton's services were in great demand by the friends of Hugh L. White in the campaign then raging in Tennessee, but if he was not there in person he most likely was in purse.

But the rain! It had been falling for several days and more came that morning. The track was muddy and full of puddles. "In some places the track had been ploughed. Exception was taken and overruled."

Honorable Henry Clay and H. Daniels were the Judges and Mr. Prestbury the Timer. Rodolph was ridden by "a darkey in a purple jacket" and Angora by "Anthony a yellow boy in green jacket and cap."

"For days previous," wrote a Louisville Journal correspondent, "Angora was the favorite, the mainstay and cherished hope of the knowing ones. They looked upon her as the lioness destined to crush in embryo and silence forever the claims of Kentucky for speed, bottom or stock in horses. Two to one and even greater odds were bet with a recklessness which testified that their confidence amounted almost to a certainty, thus treating our modest but gallant champion with contempt. Some even went so far as to wager that Rodolph would be missing at the appointed time and the forfeit surrendered."

Continuing: "The day has arrived, the crowd collected, and the eventful hour is rapidly approaching. Pocket books are open and lots of bank bills fluttering in the breeze. Rodolph, that lordly steed, is on the track. Look at him as he walks down the stretch, curving his proud neck and disdaining the earth he treads. Already, methinks, he is chuckling internally at these rash adventurers who have come to his own door-sill to snatch away his empire.

"'How are the bets now?' 


\section{I80 Making the American Thorougbbred}

voices.

"'Even! Even!' is echoed and re-echoed by a thousand

"'Where are your two-to-one betters, the wealthy Southrons, and especially the sharp eagle-eyed knowing ones?' " 'Clear the track, the riders are up,' is rung like a peal of thunder throughout that vast agitated concourse. What a tremendous throbbing and palpitation is going on in the breast of many a luckless wight who has staked the needful on the issue.

"Hark! the drum is tapped and they are off.

" "Angora ahead - go it Tennessee!' is now shouted in wild delight by the knowing ones, - 'where are you Kentuck?'

"'She is nowhere,' says a big double-fisted fellow who has but nine shillings on the race (a Cincinnati wager), 'Kentuck is where she always was and ever will be - behind Tennessee.'

“' Never mind,' cries a rough honest looking laborer, who has bet his month's wages on Rodolph, 'you'll see what's what before long; if Tennessee beats old Kentuck this heat I'Il bet two to one the mare's tail' drops off at the Judges' stand. Look there, my darling; hurrah, my Rodolph - by Juno he has licked her the second round, and if he hasn't run clear from under the rider's cap I wish I may be shot; and by the memory of Daniel Boone, if the bay will slacken a bit, I'll bet Rodolph can run clear out of his own skin. Go it, ye cripples! Rodolph against the world, and fling in a railroad.'

"And so, indeed Rodolph had passed the boasted heroine of the South, just like a knife, after Ioping behind her for gallantry's sake, a mile or two. The way he came around the fourth time wasn't slow, and the way Angora was distanced was nobody's business but her own, and that of the knowing ones." 
Perhaps a more intelligible account of the race would be to say that Angora was "unaccountably tired" and was distanced in the first heat, Rodolph running all the time under a strong pull; time 8:56.

"Angora, the vanquished," continued the correspondent above quoted, "was led off to her stable and Rodolph the victor, attended by a band of music, led off the multitude of joyous friends to Oakland House where he was greeted with a volley of loud and piercing plaudits.

"Old Hickory, the greatest and best, looking through the vision of second sight, foretold the triumph of Rodolph. Many thought he was playing the courtier to our state, but now they are convinced he knows more about horseracing than he ever did about the affairs of the nation."

Many similar bucolic exhibitions of overmuch joy are to be found in the Kentucky papers of that time; even the Kentucky poets made Rodolph's victory an excuse to chant their triumph in genuine "pennyrile" doggerel.

According to a Boston newspaper, \$200,000 was wagered on the result.

Immediately after this race Hugh Carlin, of Alexandra, Louisiana, offered to run Linnet (by Leviathan) against the victor, 3 or 4 -mile heats, over the Natchez, Mississippi, course for $\$ 10,000$ to $\$ 30,000$, which the owners of Rodolph refused.

Possibly before the race was run, possibly after, Angora was sold to Col. A. L. Bingaman of Natchez, Mississippi, who, rumor said, lost $\$ 40,000$ by her defeat. At any rate she was taken from Louisville to Natchez as Bingaman's property.

Rodolph, in January following, was purchased for $\$ 15,000$ by a Vicksburg company, in which Col. Osmund Claiborne was interested. Rodolph, after his victory over Angora, gave and received several challenges, and one or 


\section{I82 Making the American Thorougbbred}

two races were arranged, but none of them ever materialized. He was billed to meet Angora again on May I7, 1838, in a 2-mile heat race at Natchez; but about April I, because of lameness, it was said, paid forfeit of 500 bales of cotton, worth $\$ 10,000$, and returned to Kentucky, his Mississippi owners having sold him for $\$ 20,000$ to Lexington parties for use in the stud.

It is barely possible that Rodolph's owners feared the result of this contest with Angora who, within less than one year after her defeat at Louisville, had won a series of brilliant races in Mississippi and Louisiana, ten of which had been won without losing a heat.

At New Orleans, on March 17, I837, Angora met six competitors, several of whom were from Virginia, four of whom were sired by sons of Sir Archy, and one of whom had the same degree of relationship that she had to Pacolet. This contest, according to The Spirit of the Times, "presented one of the most brilliant and gratifying spectacles ever witnessed upon an American race course. Owing to continued rains the track was heavy, but otherwise everything was in apple-pie order. Not less than ten thousand spectators were upon the field, comprising a large portion of the intelligence, fashion and wealth of Louisiana and the neighboring states. The gay Orleanos turned out en masse to swell the concourse, and the lovely belles of that queenly city, radiant with beauty and delight, lent a most inspiriting and seductive influence to the manly and gallant sports of the Turf.

"Great numbers were prevented from attending, from the difficulty of procuring a conveyance to the course, though two trains of railroad cars and a monstrous steamer commenced their trips early in the morning. Every horse and carriage in the city was also put into requisition, notwithstanding which, the number of applicants 'oversized 
their pile.' Many persons determined to see the race were compelled to walk, as they did, under a burning sun four miles and a half; no joke, by the bye, though it shows the interest the races have excited in the city of New Orleans. The receipts on the course may be guessed at when we state that Capt. Y. N. Oliver, proprietor of the track, sent into the city in the evening three barrels and a half of dollars."

Angora was the favorite, the odds being as high as four to one on her against the freld. She carried roo pounds and won "amidst the shouts of her friends." Time 2:0 I I: 59 .

"Angora's success here," the Spirit's staff correspondent continued, "and at the last Natchez meeting, entirely removes the unfavorable opinion caused by her defeat by Rodolph at Louisville. The Leviathans have now most certainly proved themselves the fleetest and the best mile and 2-mile horses in the Southern country, beating everything they have contended against at these distances."

Crowned with the laurels of this great occasion let this product of "old Sumner" pass into history. 


\section{THE LEVIATHANS vs. THE LUZBOROUGHS AND OTHERS}

"The Luzboroughs have arrived."

So wrote Thomas Barry, of Gallatin, to The Spirit of the Times in February, I838.

And everybody in Tennessee, and in the whole South, for that matter, knew what Barry was writing about.

But now there may be some that do not know, and explanations are in order.

It started a few weeks after Gen. Desha bantered the world to test the qualities of his Leviathan filly, Angora. Before negotiations to that end could be completed, Leviathan's owner, himself, was called upon to make good his claims for the get of his famous stallion.

In January, 1836, the report reached James Jackson, owner of the imported stallion, Lapdog, that the lessees of Luzborough, at Franklin, Tennessee, had been saying bad things about Lapdog, with the intention of injuring his reputation as a sire. Jackson at once issued a challenge for a test of speed and endurance between the get of the two horses. This challenge was carried as a "standing ad" in the Nasbville Whig for several weeks and was the beginning of a bitter controversy of two months' duration between Jackson, on one side, and Thomas A. Pankey, of Franklin, and Rev. Hardy M. Cryer, on the other. Communications were printed as advertisements. In one communication, answering Cryer, Jackson said:

"We have for a long time tried to avoid Parson Cryer (officious and intermeddling as he has been), in conse- 


\section{The Leviathans vs. The Luzboroughs 185}

quence of his anomalous and irresponsible situation half parson, half horseman - if we bantered him he would plead the benefit of clergy; and as to newspaper controversy, it is his delight. We can contend with sporting men, but warring with a parson is like warring with women."

Pankey, professing to represent as their "friend," not "agent," the owners and lessees of Luzborough, declined to give Jackson the benefit that "would be derived from associating Lapdog with Luzborough," but he would consent for Luzborough's get to meet the get of some "respectable" horse. Leviathan he considered respectable, and he proposed (omitting details) a match race of 4mile heats for $\$ 5,000$, half forfeit, between the then living get respectively of Luzborough and Leviathan; each side to name three horses from whom a contestant should be chosen; the race to be run at Nashville in May, 1838 . "Now gentlemen, stand up to the mark - no dodging let us have neither flashes nor snaps."

After a counter proposition by Jackson, and a conference between the parties at the Mansion House, adjoining the Nashville Inn, in April; and after consultation with Merritt \& Merritt, Virginia owners of Luzborough; and after concessions by both sides, an agreement was finally reached, the general terms of which were as stated above.

Pankey named Picton, dam Isabella by Sir Archy; Leila, dam Sally Hope by Sir Archy, and another. Jackson named Sarah Bladen, dam Morgiana by Pacolet, and two others. The agreement was reduced to writing, security given, and the issue was joined between the House of Luzborough and the House of Leviathan. The news went forth and the talk began.

Picton - and Leila - were bred and owned by Col. William Wynn, of Virginia. Sarah Bladen was bred and owned 


\section{I86 Making the American Thorougbbred}

by Col. George Elliott, of Sumner County. All of the horses, at the time of their entry, were two years old, with reputations yet to establish. With the hope of establishing Sarah's reputation at once and for good, Col. Elliott, in July, 1836 , offered to run Sarah in a match race, 2-mile heats, the following year for $\$ 5,000$, but his banter went unaccepted.

Early in their careers it became evident that the contest would come between Sarah Bladen and Picton. The making of their records for excellence was like the building of two parallel columns of apparent equal dimensions. Picton ran in the East, Sarah Bladen in the South. Reports of the victories of one were followed in quick succession by reports of the victories of the other. For two years they were bright stars in the racing frrmament and kept the coming contest in the public mind. In addition to their parallel of victories, the bitter controversy, and the fame of Leviathan's get, there were two or three incidents that fed the flame of popular interest.

In her 3-year old form Col. Elliott sold Sarah Bladen to John R. Head of Manchester, Mississippi, for $\$ 8,000$, the highest price ever paid for a 3-year old in the United States up to that time. Head, about two months before the race, much to the surprise of everybody, sold her to Thurston \& Pryor, of Natchez, for \$5,500. Pryor was Bingaman's trainer and Thurston "his man Friday." The purchase was looked upon as being - and it was that of Colonel Bingaman.

The fact that after leaving Elliott's hands Sarah ran as the entry of James Jackson, showed the public that Jackson's influence was at work in the management of her races, and that he was grimly determined to teach Mr. Thomas A. Pankey and Rev. Hardy M. Cryer a thing or two about the House of Leviathan. A knowledge 

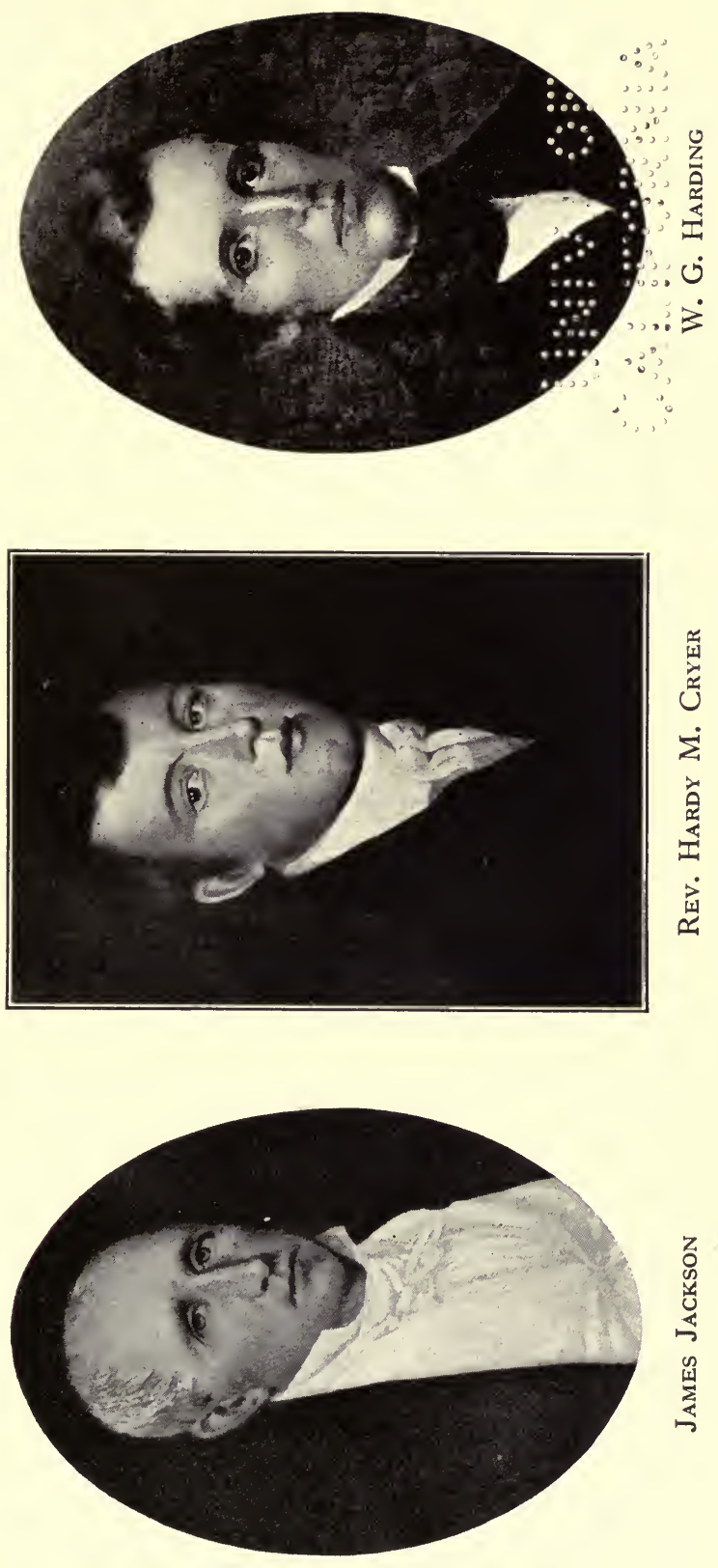


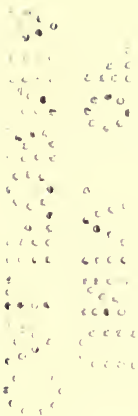


of all these circumstances is necessary to fully comprehend the stir this contest created.

In February, 1838, the three Luzboroughs reached Franklin, Tenn., to be trained for the contest, May 22. Their arrival set the experts to figuring, the partisans to arguing. On rainy days - and other days - around cross roads stores, post offices and taverns, from February even unto May, it was made clear to all attentive listeners that it would be impossible for either Picton or Sarah Bladen to Iose. Those who had been hard pressed by Old Hickory's - or Nick Biddle's - panic, now had a glorious opportunity to get on solid ground again by heeding the unselfish advice of widely divergent experts.

“"A Dukedom to a beggarly Denice,' wrote Thomas Barry, in the letter above referred to - " "A Dukedom to a beggarly Denice' that Picton gets the money. Any colt that can run four miles in 7:44 and then be well up in two other heats run in $7: 43 \frac{1}{2}-7: 56$ must be 'the very glass of fashion and mold of form.'

"This affair of honor," wrote Rev. H. M. Cryer, on April 2, "has created an unheard of degree of excitement in the whole South and West, from the mountains to the seashore; and really there is much at stake, not only in the form of bets; but the value of the stock owned by the numerous individuals in the get of the two horses is immense. It is Napoleon with his legions of honor vs. Wellington and his invincibles. Sarah Bladen and Picton seem to fill the eye of every breeder. . . . Picton looks like he was made of war-like material. . . . And it is thought here by many knowing ones that Picton will lead the circular dance from the time the music begins, or that he will urge Sarah at such a rate for the first three and a half miles that the heat of the furnace will endanger the collapsing or bursting of her boilers." 
But there were many who thought otherwise, as shown by this letter from Lucius J. Polk, written from "Hamilton Place," Mt. Pleasant, on April 7. "The betting between Picton and Sarah Bladen," said he, "still goes on, I think with increased vigor; it will be the most spirited betting race that has ever been seen in the Western country; old men and young, 'gals and boys,' are all taking a turn at it."

Sarah Bladen reached the Nashville race track about May I, to "await with patience the coming contest." A Hopkinsville sportsman who went to Nashville to look over the freld, wrote under date of May 4: "The betting about Nashville seems to be in Sarah Bladen's favor; and had Picton never won a 4-mile race, I would incline to the belief that Sarah would beat him. But his race in New York is hard to beat; but with the management of Col. Elliott, and the training of Col. Watson, and the strength and stride of Sarah, and a sandy track, the laurels may be plucked from the gallant little Luzborough."

This contest between the House of Luzborough and the House of Leviathan was the most important event in Tennessee in 1838 - in the estimation of thousands of people then living. For months before, it was the controlling factor in determining plans for the future. The conclusion of the race was the time agreed upon in advance when men would pay their debts. Trips to Texas, North Carolina, and Mississippi and other states were postponed until after the date of this contest. Horses were fattened to sell on that day, and the buying of carriages was planned to take place after the race had been run. Even Cupid had to stand aside for the time being - two young people in Maury County fixed their wedding day for "some day after the race."

These things were recorded at the time as solemn truths 
by a reputable correspondent in the midst of the scenes and inhaling their atmosphere. This correspondent's wife made a special exception of this great event and let him leave home, but only on condition that he would bring her "a handsome bonnet - 'she needed one' - and the baby a hat." Confident of his superior judgment of a horse, and overjoyed at her generosity, he promised to bring his wife two handsome bonnets and the baby a dozen hats.

"Upon arriving in town," says this unchained husband, writing in The Spirit of June 2, "I found it perfectly full; at one of the hotels I heard the proprietor telling the barkeeper that in case he had to receive more company, there was still room for six on the floor. But still they came like flocks of wild pigeons visiting the settlements; some of them doubtless resembling the pigeons in other particulars; and where pigeons abound hawks will hover, so of the latter there was at least quantum suff."

From tavern to tavern flew many and conflicting rumors, and many secrets: the "Leviathan party" were trying to buy Picton at $\$ 16,000$ and bet all they could, play or pay, against him; Picton had let down and his sinew was like a hoop; Col. Wynn had been asked about it and had answered that Picton was as fine as silk; Leila was better than Picton at any distance, anyhow, and she would be selected for the race; and, Iastly, there would be no race at all.

The truth was that Picton's right fore leg was found to be sprung which caused an enlargement in the tendon. AII efforts to remove the inflammation and ally the fever in time for the race proved futile and Pankey announced, on the day before that set for the race, that Leila would represent the blood of her sire. Then the betting commenced at 2 and 3 to $I$ on the Leviathan, which was freely 


\section{I90 Making the American Thorougbbred}

taken by the "Luzborough faction." "It was sinful," wrote the gentleman above quoted, "the way the Mississippi paper was planked up; the start was delayed until after one o'clock, apparently to give full time to every one to settle his bets; some were hedging, but all was piled up, every dollar. A large portion of the bets having been made between Picton and Sarah Bladen, and not on the match, were of course off. Tall sums had been staked on the event through all the South; one gentleman in Louisiana is said to have stood \$ 1 , 000 on it."

Sarah Bladen was described as a "beautiful creature," well formed, possessing apparently great endurance and the most perfect Leviathan that had appeared up to that time.

The day of the race was cold and rainy, but an immense crowd was on hand. The Judges were: H. Petway, Samuel Ragland of Alabama, H. L. Douglass and L. P. Cheatham; Distance Judges, Thomas Alderson and John S. McNairy; Patrol Judges, W. G. Harding, P. Higgins, H. Compton and William Gowen; Timers, E. H. Boardman, of Huntsville, Alabama, and Hugh Kirkman.

"Leila went off ahead," The Spirit's correspondent continued, "but a few bounds placed Sarah before her, Dick exerting all his strength to hold her in. She seemed to disregard the mud, or, as some one said, ran fastest where it was deepest. In half a mile the tale was told, 'the dog are dead,' said some. In a mile a blanket would have covered them both, provided it was a hundred yards long. Leila struggled hard after her but she couldn't shine, and had no link to let out; she could not keep up a perpetual brush. Sarah came out in a common canter, leaving her out the distance. Time 8:50. This solves the problem of the Leviathan's running 4-mile heats, to the satisfaction of some, at least." 
Thomas Barry, of Gallatin, did not belong to the satisfred set. Immediately after this defeat of the House of Luzborough he, as champion of the get of his stallion, Cock of the Rock, threw down the gauntlet to the House of Leviathan, and James Jackson took it up. Each named three entries from which number a contestant was to be selected for a match race to be run at Nashville on October I, as the opening event of the six day Fall meeting. It was to be a 4 -mile affair of 4 -year-olds, for $\$ 1,000$ a side, P.P.

When the time came Barry entered a bay filly out of NeIl Saunders by Wilkes' Wonder, 'taken up but a few weeks before and amiss when started." Jackson entered Exotic, a filly out of imp Refugee by Wanderer. Each entry carried 97 pounds. The track was very deep and heavy. Exotic was the favorite 3 to $\mathrm{I}$ and won easily. Time 9:40-9:33.

At this same meeting a match for $\$ 5,000$ a side, 4 -mile heats, between the get of Leviathan and the get of Bertrand, was.billed, with W. R. Peyton's Blacklock, out of Kitty Clover (by American Eclipse), 3 years, representing the Bertrands and W. J. Minor's Thrush, out of Object (by Marshal Ney), same age, representing the Leviathans. The latter being amiss paid \$2,500 forfeit.

Though prevented from running against Sarah Bladen, Picton was yet to test his speed and strength with that of a Leviathan and make amends to Tennessee sportsmen for the disappointment he had caused them. At Nashville, on Oct. I I, I839, in a race of 4-mile heats for a Jockey Club purse of $\$ 1,000$, the contestants were Picton, still owned by Col. Wynn, and entered by L. P. Cheatham; Col. George Elliott's Boyd McNairy, full brother to Sarah Bladen, entered by James Jackson; and Alex Yourie's Osceola, by Pacific, dam by O. H. Perry, entered by G.W. 


\section{I92 Making the American Thorougbbred}

Cheatham. Picton and Osceola, 5 years, carried I Io pounds, Boyd McNairy, 3 years, 86 pounds.

"All parties," wrote a staff correspondent of The Spirit of the Times, "agree in pronouncing this one of the finest races ever run over the Nashville Course. Picton was booked to win it to a certainty and was the favorite at odds against the freld, notwithstanding that his forelegs were sprung. . . . Osceola had many friends from the fact of his having recently won the 4-mile purse at Gallatin, but the main dependence of the fielders was Boyd McNairy, the own brother to Sarah Bladen. He was believed to be both stout and fast, though he never ran even a trial over two miles. He is a fine looking iron gray colt, of rather above the medium height, with long arms and powerful hocks and quarters. Osceola (better known as Sheridan) is a horse of high form and finish, nearly is hands, 3 inches high, a beautiful bay with black legs and no other white than a small star. He is the handsomest son of Pacific we have ever seen, and his performances are calculated to add new laurels to the many won by his sire."

Osceola took the lead in the first heat, kept it and won easily. He was jockeyed by McClinchey, from the stable of Lucius J. Polk. McClinchey had ridden the winner in three of the six races run during that week. Before the second heat started, Polk and Balie Peyton bought Osceola for $\$ 6,000$.

Osceola got the leati in the second hẹat, Picton being second and Boyd McNairy a bad third. So it continued for a mile and a half, when McNairy went up, lapped with Picton for 50 yards, passed him and collared Osceola. Picton was out of it. It was nip and tuck from then on between McNairy and Osceola, first one and then the other having the advantage. Soon after entering the back 
stretch McNairy challenged Osceola for the lead, "and after a spirited burst took the track and maintained it to the end, winning the heat in 8:04. The result of the heat caused something like 'a determination of blood to the head' among the betting men; the frelders had already won their money, and thinking to parole laid it out at 3 to I on McNairy with those of Picton's backers who were not broke."

And how were Balie Peyton and Lucius J. Polk feeling about that time?

"For the third heat," says The Spirit's correspondent, "McNairy led off at a racing pace, but directly gave up the track to Osceola and trailed him, laying well up with the intention of putting the issue upon a brush. Down the quarter stretch Osceola pulled to him and they came out lapped; McNairy took the track at the turn and Osceola commenced driving him; the latter drew out and lapped him for a few yards at the end of the first half mile, which had the effect of making him carry on the running at a better pace. McNairy was two lengths ahead at the second mile, but immediately he cleared the turn McClinchey called on Osceola who locked him, and a desperate struggle ensued; for sixty yards they ran neck and neck, neither seeming to gain an inch on the other; each 'did all he knew' and for a few moments the interest excited was intense. But the game and stamina of the horse at length told and he came in front and took the track. McNairy subsequently made a gallant effort to reach him, without effect, and throughout the last mile the gap widened, Osceola finally winning at his ease."

The House of Pacific had vanquished both the House of Leviathan and the House of Luzborough. Whereupon Hon. Balie Peyton proceeded to pocket his winnings and sell his interest in Osceola to Lucius J. Polk, at a profit. 


\section{THE PEYTON STAKE}

\section{“SWEEPSTAKES OF \$ 5000 EACH SUBSCRIPTION"}

"We, the undersigned, agree to run a Produce Stake with colts and fillies dropped in the spring of 1839 , over the Nashville (Tenn.) Course, Four-mile heats, on the second day of the Jockey Club meeting on said Course, in the Fall of 1843 . Sub. $\$ 5,000$ each, forfeit $\$ 1,000$. The rules of the Nashville Jockey Club to govern said race. If man, colt or filly dies, no forfeit to be claimed. Three or more to make a race; to close on the first day of Jan. 1839.

\section{"SUBSCRIBERS"}

"Balie Peyton and J. G. Chalmers name produce of Black Maria (by Eclipse, out of Lady Lightfoot by Sir Archy) and imp. Luzborough.

"B. Peyton and A. Henderson name produce of Maria Shepherd (Lilac's dam - by Sir Archy, dam by Shylock) and imp. Priam.

"James Kirkman names the produce of imp. Eliza (by Rubens, out of Little Folly by Highland Fling) and imp. Glencoe."

This agreement was printed as an advertisement in The Spirit of the Times, for the first time, May 19, 1838 . The incidents that led to it, and the events that followed, make a notable chapter in the history of the American Turf.

After a successful career extending over more than a score of years, as a breeder of thoroughbreds, John C. Stevens, of New York City, turned his attention to yachting, advertised for sale all the thoroughbreds on his farm at Flat Bush, Long Island, and shipped some of them in charge of his trainer, Isaac Van Leer, to New Orleans, hoping to find there an open market. Of the number so 
shipped was Black Maria, who, "when fit was too fleet for the fast and too stout for the strong." When led out on the levee at New Orleans, on March 29, I838, Black Maria received an ovation to which her fame well entitled her. If Balie Peyton was not in that throng of welcoming admirers his appreciation of the mare was, nevertheless, soon manifest; in company with his law partner J. S. Yerger, of Vicksburg (formerly of Nashville), and his friend Dr. J. G. Chalmers, of New Orleans, he bought her for $\$ 4,000, \$ 1,500$ less than Stevens had declined to take for her a year previous.

In the same issue of The Spirit which contained the proposition, above quoted, appeared an editorial endorsement of it.

"In Tennessee and Louisiana," Editor Porter wrote, "people will tell you that "whatever Balie Peyton says is gospel'; and he writes us that this stake must be made a National Affair. He thinks Kentucky is bound to come in, and Tennessee and Alabama, also. 'And I do not see,' writes Mr. P., 'why the gentlemen of Carolina, Georgia and the Old Dominion - of Maryland, New Jersey and New York - should hesitate to join us and make this stake the most splendid and attractive ever run in America.",

Thus Peyton's proposition went to the world in the fullness of its growth and, by general acclaim, became "the Peyton Stake."

But the mature plant had its real germ (according to the statement made by The Spirit's staff correspondent, in his account of the race) "in the rivalry and difference of opinion between the 'friends' of Glencoe and Luzborough, as to their respective merits, at the time, or shortly after, Picton had been making such havoc at the North. Mr. Van Leer, the agent of John C. Stevens, had concluded 


\section{Making the American Thorougbbred}

to send Black Maria to Glencoe, and upon the subsequent purchase of her by the Hon. Balie Peyton, it was determined that she should go into the harem of Luzborough. One of the owners of Glencoe, somewhat nettled at the change, immediately challenged with the get of Glencoe - from imp Eliza by Rubens of the same year. The proposition was accepted and subsequently converted into a sweepstake," etc., etc.

According to a statement of Mr. Alex Jackson, grandson of James Jackson, now (1916) residing in Mobile, the Peyton stake originated in a "friendly game of Boston," in Nashville. Mr. A. D. Hunt, a son-in-Iaw of James Jackson, and connected with a cotton factory at Florence, stopped over in Nashville, on his way to Kentucky, and while participating in this "friendly game of Boston" the conversation turned to race horses. The Nashville "Bostonians" ridiculed Glencoe in the strongest terms; at the same time they lauded Luzborough.

To season their conversation they proposed a wager of \$5,000 on one of Luzborough's get, against any one of Glencoe's Hunt might select, 4-mile heats, over the Nashville course. Hunt answered that he had no pecuniary interest in Glencoe, nor in any other thoroughbred, but that if the matter were submitted to Mr. Jackson he would doubtless accommodate them.

On his return to Florence, Hunt told Jackson what had occurred. Jackson took up the matter and proposed to make the contest open to the whole world, he to enter nothing but Glencoe's get.

In the one essential particular, viz., that the Peyton stake had its origin in the feeling between Jackson and the Tennessee lessees of Luzborough, the two versions above given coincide and are corroborated by the written proposition previously quoted. 

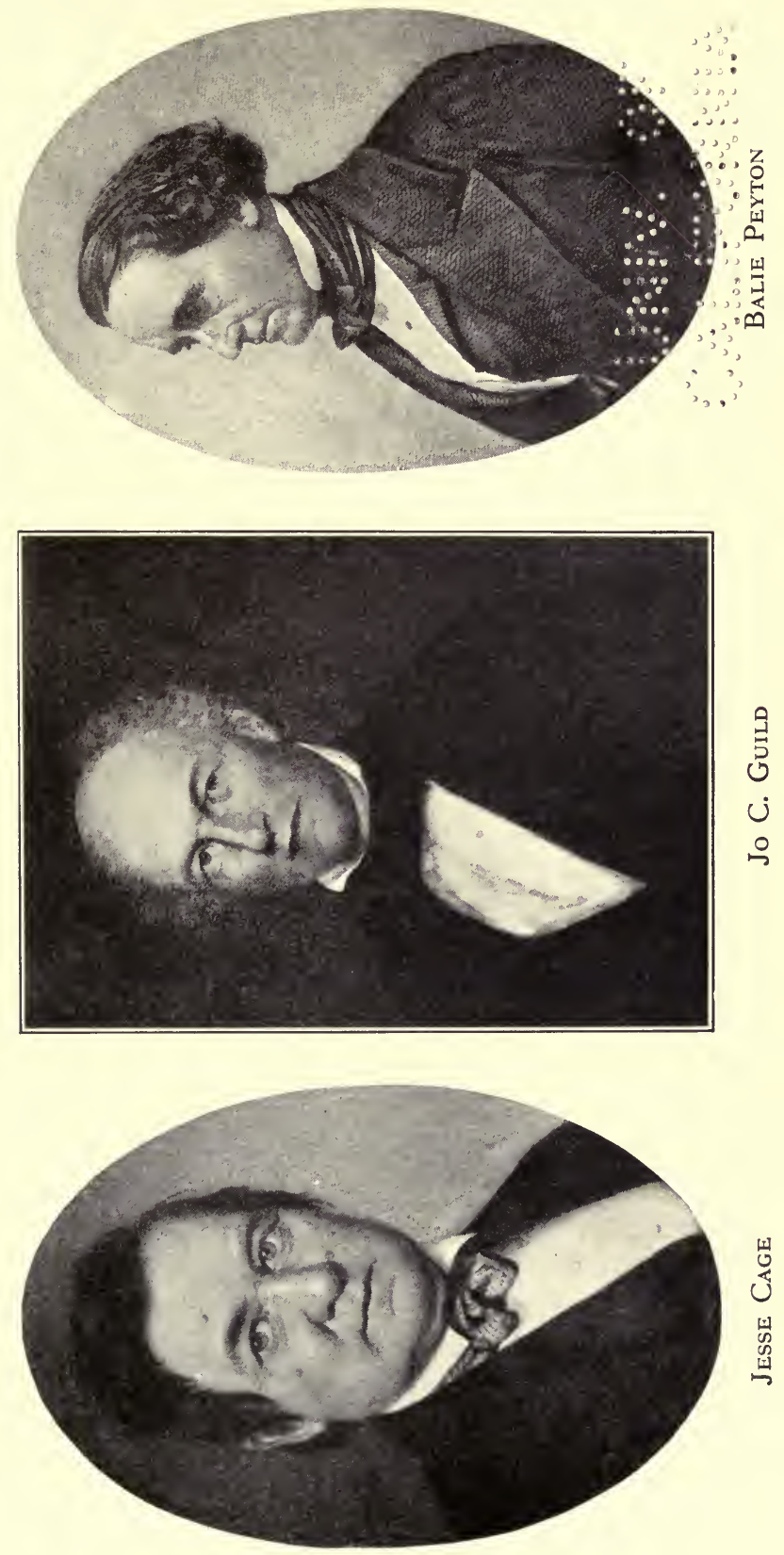


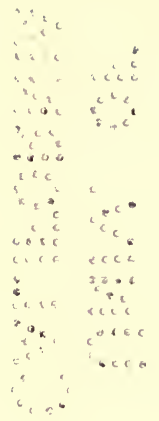


The subscribers to this stake filed lists of their entries with Hugh Kirkman, Secretary of the Nashville Jockey Club. The 3oth entry was made in a letter mailed in North Carolina on January I, I839, and was accepted, by unanimous consent of subscribers, after certificate showing date of mailing had been secured by the Secretary. After the entries were closed the complete list was officially signed by Secretary Kirkman and was carried as an advertisement in The Spirit of the Times for a year or Ionger. Quoting from Secretary Kirkman's official list the following nominations were made after the proposition previously quoted was issued to the country:

"4. Col. Wm. Wynn of Va. names the produce of Isabella by Sir Archy, and Imp. Priam.

"5. Also the produce of Trumpetta by Mons. Tonson, and Imp. Priam.

"6. Maj. Thos. J. Wells of La. names the produce of Imp. Pickle by Emilius, and Imp. Glencoe.

"7. James Jackson of Ala. names the produce of Imp. Delight by Reveller, and Imp. Glencoe.

"8. Col. Thomas Watson of Tenn. names the produce of Giantess by Imp. Leviathan, and Imp. Glencoe.

"9. John Boardman of Ala. names the produce of Imp. Miss Golborne by Lottery, and Imp. Berners' Comus.

"Iо. Wm. G. Haun of Miss. names the produce of Rattlesnake by Bertrand, and Imp. Hedgeford.

"II. Col. Geo. Elliott and H. and J. Kirkman of Tenn. name the produce of Hibernia by Sir Archy, and Imp. Leviathan.

"12. Also, the produce of Imp. Florestine by Whisker, and Imp. Leviathan.

"13. Maj. A. J. Davie of Tenn. names the produce of Imp. Doris by The Colonel, and Imp. Lurcher.

"14. Henry Wilkes of Md. names the produce of Flirtilla by Sir Archy, and Imp. Priam.

"I5. James Long of Va. names the produce of Flirtilla Jr. by Sir Archy, and Imp. Priam

“i6. P. A. Prindle of S.C. names the produce of Aggy-Down by Timoleon, and Imp. Priam. 


\section{I98 Making the American Thorougbbred}

"17. Hon. Alex. Barrow of La. names the produce of Lilac by Imp. Leviathan, and Imp. Skylark. 。

"18. Col. A. L. Bingaman of Miss. names the produce of Own Sister to Betsy Malone by Stockholder, and Woodpecker.

"19. Henry A. Tayloe of Ala. names the produce of Howa by Imp. Luzborough, and Mingo.

"20. John C. and Hugh Rogers of N.C. name the produce of Polly Peacham by John Richards, and Imp. Priam.

" 2 r. W. D. Amis and M. Hunt of Miss. name the produce of Eliza Drake by Shawnee, and Imp. Chateau Margaux.

"22. Col. Wade Hampton of S.C. names the produce of Imp. Delphine by Whisker, and Plenipotentiary.

“23. W. H. E. Merritt of Va. and L. P. Cheatham of Tenn. name the produe of Alice Riggs by Imp. Leviathan, and Imp. Skylark.

"24. John C. Beasley of Tenn. names the produce of Kathleen by Imp. Leviathan, and Imp. Skylark.

"25. Maj. W. R. Peyton of Tenn. names the produce of Black Kitty Clover by Eclipse, and Pacific.

"26. John Blevins and Samuel Carter of Ala. name the produce of Miss Medley by Medley, and Wild Bill.

"27. J. Morrison Pindell of Ky. names the produce of Marcella by Alfred, and Eclipse.

"28. Wm. H. E. Merritt and Brother of Va. name the produce of Robt. C. Williamson's Imp. mare Pera by Sultan, and Imp. Priam.

"29. Also the produce of Imp. Bustle by Whalebone, and Imp. Priam.

"3o. John C. Rodgers of N.C. names the produce of Maria West by Marion, and Andrew."

Summarizing: Priam stood to sire 9, Glencoe 4, Skylark 3, Leviathan 2, and the other horses one each. The 30 mares were believed to be as good as any 30 in America. No stake at all comparable to this had ever been made up in this country or in Europe. It created a sensation, even in England, and made Balie Peyton's name familiar to devotees of the thoroughbred, from Cumberland to Surrey.

There were seven chances that this $\$ 150,000$ would go 
to some one in Tennessee, five chances that it would go entirely, or in part, to Sumner County, and three chances that a large part of it, if not all, would be carried home to "Station Camp" by Balie Peyton or his brother, "Ran." Under such circumstances it is barely possible that the Peyton stake created as great a sensation on Station Camp Creek as it did on the Don, the Humber or the Thames.

Balie Peyton's anxiety, as well as his optimism, were displayed in letters to his friend Porter, editor of The Spirit. "Black Maria is to immortalize me yet," he wrote on January 10, 1839. In response to his "anxious inquiries" his brother "at home" had just written him that Black Maria, in the "opinion of all," was in foal.

Nearly two months later Peyton had the "pleasure of announcing" to Editor Porter that Maria Shepherd had produced Hector, on February I2, and that Rev. H. M. Cryer, after viewing his "Sir Archy shoulders" and "Tonson hocks," had pronounced him, "Sir, a prize." "The good news don't stop here," said Peyton, "Black Maria is certainly with foal. Let old Ironsides send forth her artillery, and may I not consider the change mine, and lay it out in a sugar plantation at once?"

With the arrival of Black Maria's foal on April 28, as announced in The Spirit by Peyton's sister, Mrs. G. W. Parker, the only question to be settled was the size of the sugar plantation. This had to be cut down as reports from the seven states showed, from various causes, a considerable reduction in the number of possible starters. But the winnings, even then, would be sufficient for a fair-sized plantation, and Peyton declined to throw away a certainty by accepting an offer of $\$ 6$, ooo made in June for Black Maria and her little Great Western.

The contest took place Oct. Io, 1843. "The number of the nominations," wrote "Rover" the staff correspondent 


\section{Making the American Thorougbbred}

of The Spirit of the Times, who witnessed the race, "the high breeding and promise of the colts, the character and respectability of the parties concerned, with the great value of the stakes, induced a great number from all parts of the United States to embrace the opportunity to visit for the first time, the great western Valley, to view her broad, bright streams, her fertile lands, her rising cities and teeming population - with steam boats crowding the great highway of waters, like the market wagons of the east - then landing at Nashville, one of the most picturesque and thriving cities of the West - and, as a finale to such a trip, to enjoy such a race meeting as has never before occurred in our country, and which no one can hope to witness again."

Ample arrangements had been made to take care of a large crowd.

The only unpleasant feature was the condition of the track. Incessant rain on the 7 th and 8 th, followed by wind and sun on the 9 th, had left it very heavy with sticky mud. But the day itself, "opened delightfully. The sun shone forth with cheerful effulgence, gladdening every heart and brightening every eye. The attendance was worthy the occasion. About ro o'clock the crowd took up their line of march to the race course, distant about one mile, and from that hour until I o'clock P.M. the road presented a continuous line of pedestrians, equestrians, omnibusses, carts, drays and carriages of all descriptions. Upon reaching the course the picture was perfect. The stands were crowded - the freld presented a dense mass of human beings in the highest possible glee. The ladies' stand was illumined with an array of beauty and fashion that would have moved the soul of an anchorite."

Among the distinguished strangers who honored the course with their presence were Hon. Alex. Barrow and 
Hon. Balie Peyton of Louisiana; Hon. J. J. Crittenden of Kentucky; Ex-Gov. Butler; Col. Wade Hampton and Col. Singleton of South Carolina, and Maj. John M. Huger, Robt. Purris, Esq., Capt. Nicholas Davis and Maj. Saml. Ragland of Alabama.

The Judges were Capt. Nicholas Davis, Col. Jesse Cage, of Gallatin, and L. P. Cheatham, of Nashville. Governor Pierce M. Butler, of South Carolina, and James A. Valentine acted as Timers.

When the bugle sounded the call at I o'clock only 4 of the 30 nominations came to the post, thus reducing the possible $\$ 150,000$, of 1838 , to $\$ 35,000$.

First came Alex. Barrow's ch. colt by imp Skylark out of Lilac by imp Leviathan. He had been trained in the stable of H. M. Clay and was ridden by John Ford. He was 16 hands high, " as strong as a wagon horse though not so coarse," in good condition and "his party was sanguine."

Second came Balie Peyton's Great Western, trained by Capt. John Belcher, of Virginia (who first trained Boston), to be ridden by Monk (colored). She was a dark brown, of good size, closely resembling her dam, in fine condition, and "her chance was considered a good one."

Third, came Thomas Kirkman's Glumdalditch, by Glencoe, out of Giantess by Leviathan. She had been trained by Isaac Vanleer - who had remained in the South after selling Stevens' horses - and was to be jockeyed by F. P. PaImer, alias "Barney," a native of New England. Glumdalditch was "a chestnut about $16 \frac{1}{2}$ hands high, proportionately, built in every respect and in the most perfect condition, and though a dark nag - for this was her maiden entry - her owner and friends relied upon her stride, speed and breeding for a long and bruising race."

Fourth, came Wade Hampton's Herald, got in England by Plenipotentiary, out of imp DeIphine by Whisker, but 
foaled in South Carolina. He was a dark chestnut, about I 5 hands $2 \frac{1}{2}$ inches in height, handsome, strong and symmetrically formed. "Herald could not have been quite up to the mark," owing to an injury in his right foreleg, received six weeks previously. He "was to be ridden by Sandy who had been brought from South Carolina, expressly for that purpose."

The riders - all of whom stood at the head of their profession - dressed in their new and beautiful Jockey suits, displayed themselves and their horses to great advantage while cantering up and down in front of the stand, previous to starting. They had no sooner received their orders to mount than a spirited betting took place on Herald against the freld. The Skylark was the "second favorite" at starting.

The charge of the starting Judge, Capt. Davis, was "unusually felicitous and pointed. The riders then mounted their horses and took positions as above described."

The two colts carried Ioo pounds each and the two fillies 97 pounds each. Track "very muddy and heavy."

"Rover's" account of the race as printed in The Spirit of the Times follows:

"First Heat. - An excellent start. At the tap of the drum the Skylark took the lead at a slow pace, the Glencoe filly 2d, Herald behind; this order was however changed on the back stretch by the Luzborough placing herself $2 \mathrm{~d}$, and the Glencoe filly falling back to keep company with Herald, who was then some 20 or 30 yards behind the other two. In this position they finished the ist mile in 2: $29 \frac{1}{2}$. Upon entering the $2 \mathrm{~d}$ mile the brown filly increased the pace and gave the Skylark the go-by, leading up the back stretch until the $\frac{1}{2}$ mile post, when Herald apparently mastered Sandy and made a brush, leaving the Glencoe behind, and caused an increased speed on the part of the leading nags. Upon being taken in hand, he again fell back to his partner and neither of them made an effort for the heat. At the head of the quarter stretch the Skylark again 


\section{The Peyton Stake}

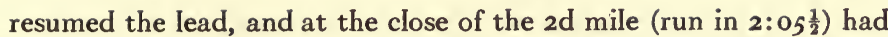
opened a gap of about 20 or 30 feet. Monk moved the filly pretty briskly around the Ist turn of $3 \mathrm{~d}$ mile, and getting fairly into straight work on the back stretch, set sail in right good earnest. The filly closed the gap before reaching the home stretch, but could not get in front. The pace seemed very slow, in closing the $3 \mathrm{~d}$ mile (2:11). The brown filly again made desperate efforts throughout the whole of the Iast mile, but to no purpose; it was evident she was mastered, and although the run she made down the last quarter stretch was very beautiful, it was scarcely close enough to be exciting - the hindmost nags pulled up quietly within the distance. The last mile was run in 2:06. The heat in $8: 52$.

"The result of the heat caused no change in the opinion of the friends of Herald, and consequently no change in the betting - Herald was still the favorite. The Skylark was thought to have won the heat by permission - the Glencoe filly was still a dark nag - the chance of Great Western was at a discount, as almost every one thought her hand had been completely shown. They all cooled off to admiration, and after the usual time came up gaily for

"The Second Heat. - Tom Mooney now took Sandy's place on HeraId, who went off with the lead - Great Western 2d, The Skylark $3 \mathrm{~d}$ - at a slow pace. The positions were unchanged during the first mile, which was run in 2:20. On reaching the back stretch of the second mile, Skylark made play, and passing Great Western, locked Herald, who shook him off a little around the next turn, and led into the quarter stretch; the speed down the home stretch was but little increased. Herald led the $2 \mathrm{~d}$ mile hard in hand in 2:17, Skylark well up. John Ford now found out that Herald could not be handled as easily as his ${ }^{1}$ antagonist, and thinking the gait did not suit him, he called upon the $^{1}$ for a little stronger head of steam, to which the animal nobly responded, ${ }^{1}$ dashed around the turn and up the back stretch; pulling again around the turn, he whirled rapidly down the home stretch, trying his persuasive eloquence. At the close of the third mile it was evident that Herald ' had the heels of him' - the time of $3 \mathrm{~d}$ mile 2:08. 'Wait and win' was not now the order of the day. The Skylark commenced the $4^{\text {th }}$ mile with the serious intention of getting home first. The pace now visibly improved, and after getting into straight work on the back side, Ford nearly locked Herald, but it was only for an instant - he shook him off readily, and led him a length or more around

${ }^{1}$ Original illegible. 


\section{Making the American Thorougbbred}

the turn. On entering the home stretch the Skylark made another. dash, but to little purpose - Herald had the heels of him and came home an easy winner of the heat. Time of $4^{\text {th }}$ mile $-2: 05$.

"Barney during the first two miles of this heat had placed himself in what might be termed a snug position to take advantage of any faux pas that might be made, or to run the Skylark for the heat, in the event of the inability of Herald to maintain his lead, and as soon as the case was explained to his satisfaction, he quietly pulled back and dropped within his distance - the Luzborough following in his wake. The heat was run in 8:50.

"The apparent ease with which Herald closed the heat, induced many to back him at 2 to I to win the race, while those who had watched with an anxious, and perhaps jealous eye, the movements of the fine Glencoe filly, now thought her chance of winning about 30 to roo, at which odds some considerable amount was laid. It was evident that she had not run a step, and her superior condition, and the skill displayed in her management, were alike the subject of admiration. In coming up for the next heat she had cooled off beautifully, and was considered by some of the best judges the only really dangerous nag in the race. Col. Singleton was free in the expression of that opinion, and wished with all his heart the race was at an end. Herald, too, came in for his share of the general approbation. He did not appear to mind the race thus far, and but for the 'dark nag,' looked very like 'the winner of the day.' The chance for the others was considered of but little importance. They are now saddled for the

"Third Heat. - Herald again took the lead, the Glencoe filly in waiting, until turning into the back stretch, when the Great Western and the Skylark, who were locked, simultaneously passed her. Great Western then took the $2 \mathrm{~d}$ place, and in this position they finished the ist mile, which was run in $2: 11$. Skylark now almost immediately passed G. W., and in swinging round the first run, she and the Glencoe ran dead locked. Great Western opened a gap on the Glencoe on the back stretch, and passing Skylark, made a dash at Herald, who shook her off; she now dropped back to Skylark, and Barney on the Glencoe now made up his mind for mischief. Upon entering the home stretch, she went up, and a simultaneous rush ensued, Herald still leading to the stand, in 2:17. Skylark now tried it on at the Glencoe (G. W. dropping behind), and they ran nose and tail to the half-mile post, when the Glencoe again gave him the go-by and prepared for a dash at Herald, which she made 
coming down the home stretch, $3 \mathrm{~d}$ mile. The speed was now greatly increased, and the contest beautiful beyond description. Barney did not quite lap Herald, but thinking he could outfoot him, took a stronger pull upon the filly, and placed himself about a length behind, at the close of the $3 \mathrm{~d}$ mile, run in 2:07. The increase of speed, put Great Western nearly out of her distance, and her position was becoming more unfortunate every step. The Skylark by persuasion kept a better place. On rounding into the back stretch, Herald again opened a gap of at least three lengths upon the Glencoe, which he kept apparently without difficulty until at the head of the quarter stretch At this point of the race, the story seemed to be told, but Barney who had been nursing his filly through all the back stretch, where the mud was deepest, and through which with Herald she could make no comparative headway, now prepared for the final struggle. He swung around the turn with great rapidity, placed himself for straight work on the hard path, on the extreme outside of the course, and taking a good pull upon the filly, drove the rowels to the head. The burst of speed which followed defies description, and is almost beyond belief - she locked him at the drawgate, and passing him almost instanter, beat him home, we are constrained to say, at her ease, by about her length, and distancing Great Western, running the 12 th mile in $1: 58$ ! The heat in $8: 33$.

"I have no words that will convey to you the feelings of the multitude. The run home was made amidst the most profound silence, which was broken only when the Glencoe passed Herald. I thought I had heard some little noise in Kentucky on such occasions, but this did indeed 'out-Herod Herod.' You have never yet heard a good old fashioned Tennessee yell. You ought to have your measure taken for one, and have it shipped by first conveyance.

"The Glencoe's Iast effort knocked aII the betting in the head, and almost any odds went a-begging; in fact, I saw nothing done in that way after the heat. Neither Herald nor the Glencoe appeared to mind the heat, and both cooled off to the admiration of all. The Skylark appeared somewhat distressed when the heat was over, but he came up boldly for the

"Fourth Heat. - This heat was almost a repetition of the last, Herald taking the lead, and keeping it most of the way, the Glencoe 2d, the Skylark behind, until the $3 \mathrm{~d}$ mile, when the Skylark challenged the Glencoe for $2 \mathrm{~d}$ place, and they ran half a mile close together, the Skylark, if any, having the advantage. On the back stretch of the 3d mile, the filly and the Skylark were dead locked, and Herald 


\section{Making the American Thorougbbred}

appeared to be leaving them, in fact opened a gap of some twenty yards upon them. This was explained by Barney, who chose to remain where he was, in the beaten path which the horses themselves had made, rather than draw out in the mud, which would throw him still farther behind. As soon as he struck upon the better ground, down the home stretch of the $3 \mathrm{~d}$ mile, she passed the SkyIark, and closed most of the gap on Herald, who led until the last quarter stretch of the $4^{\text {th }}$ mile, where Barney repeated his brush, with frightful rapidity, and beat him home by about a length in the clear. The time of the heat was 8:52.

"Thus ended the race, and thus triumphed the get of Glencoe. The day closed as it opened, and nothing occurred to mar the social harmony. The health and continued prosperity of her owner and the winner, were drunk with 'three times three' and in honor of the stake and of the gentleman whose name it bore, the gallant filly was named Peytona."

The Spirit of the Times of March 23, 1839, contains this editorial paragraph:

"We are desired to state that Col. Watson's nomination (No. 8 produce of Giantess and imp Glencoe) was foaled on the 28th Feb. It is a fine filly foal; a chestnut, with a star and no other white: measuring three feet $5^{\frac{3}{4}}$ inches."

The presumption arising from this publication and the official list of entries is that Peytona was foaled in Williamson County, Tennessee, where Thomas Watson conducted a training establishment open to the patronage of the general public. Tradition among the descendants of Thomas Kirkman, however, is to the effect that Peytona was James Jackson's entry and was foaled in Alabama. "Much could be said on both sides."

Giantess' dam was Virginia, by Sir Archy, and her grandam Virginia, by imp Dare Devil. From Diomed, Sir Archy, Leviathan and Glencoe, Peytona inherited many strains of the best blood ever known in the world; and yet in point of breeding she was but a type of the Tennessee horse of her time. 
Peytona was sluggish and awkward in slow work, but when extended her action was "express and admirable." Her stride was said to be $\mathbf{2} 7$ feet when at the top of her speed, but this was doubted by some, in view of the fact that O'Kelly's Eclipse and Flying Childers were credited with a stride of only 26 feet, while Blue Dick, Boston and Fashion could not show 23 feet. Her reach must have been unusual, for Judge Thomas Barry, who saw her run, said her majestic stride, as she came down the home stretch, created the same sensation on the mind as the sight of a great ship sailing into port. ${ }^{1}$

${ }^{1}$ For other stakes run at this meeting see Addenda I. 


\section{FASHION vs. PEYTONA}

Up to 1845 there had been four North and South matches known as the "great" matches. Two of them have been described. The other two were between Ariel and Flirtilla in 1825 and Fashion and Boston in 1842 . The ArielFlirtilla match was of 3-mile heats for $\$ 20,000$, with side bets which increased the stake to $\$ 30,000$. The FashionBoston match was of 4-mile heats for $\$ 20,000$. Both were run over the Union Course. Flirtilla was owned by Col. William Wynn, was financially backed in this contest by Dr. Wyche, of North Carolina, and was trained and managed by CoI. W. R. Johnson, who studiously eschewed lobsters and brought Flirtilla out in triumph. But his own Boston went down in defeat. The score now being even the next contest was regarded as the one that would settle the long standing sectional rivalry. This situation alone would have been enough to excite all turfdom. But, in addition, the two contestants - Fashion and Peytona - had made great names; they were believed to be evenly matched; and the fact that they, above all others, had been chosen to throw the scales to one side or the other, caused the most remarkable demonstration ever witnessed on an American race course.

Fashion was a satin-coated chestnut, with a star and a ring of white above the coronet of her left hind foot; on her right quarter she had three dark spots; was well formed; her notable points being the muscular development of her quarters, thighs and gaskins. She always ran with a loose rein, was true as steel, her isposition faultless - she could be placed anywhere. 
She was foaled April 26, 1837, and was by imp Trustee, dam Bonnets O’Blue, by Sir Charles. Bonnets O'Blue numbered among her victories a \$10,000 match with Goliah, by Eclipse, over the Union Course in 1831. Her dam was Sir Archy's daughter, Reality, "the very best race horse," said Col. Johnson, "I ever saw." CoI. Johnson had bred, trained and run Bonnets O'Blue but, unfortunately for him, had let her go into Gibbons' hands. In Fashion's veins also coursed the blood of imp Medley, Janus, Sir Peter Teazle, Highflyer, Trumpator and many other horses mentioned in this volume.

Fashion had begun her racing career Oct. 21, I840, and up to her meeting with Peytona had started 24 times, and won 23 races, 14 of which were of 4 -mile heats, 6 of 3 -mile heats and 3 of 2-mile heats; her winnings $\$ 35,600$. She was trained for all her engagements by Samuel Laird and was ridden in all of them by his son Joseph, the best jockey in the North.

She had several times beat American Eclipse's time in his race with Henry; and in her bout with Boston, she had

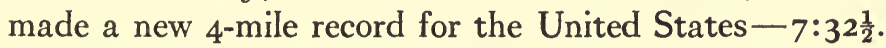
Her second heat she ran in 7:45.

Fashion was bred by William Gibbons, of New Jersey, who still owned her. Like many other breeders, North and South, Gibbons did not wager money on any race; and he had no pecuniary interest in this one. His tender of his mare to Henry K. Toler, of New Jersey, for this match was like Col.. Crowell's tender of John Bascombe to CoI. W. R. Johnson - in accordance with the usage of the times.

Peytona, since her victory at Nashville, had run only four races - three at New Orleans and one at Mobile and had won all; two were of 3-mile heats and two of 4 -mile heats. In each of her 4-mile heat races she beat 


\section{Io Making the American Thorougbbred}

her own time at Nashville: in one she ran in 7:45- 7:48 (better than Eclipse in his race with Henry) and in the other, 8:09 and 8:00. Her winnings in the four races were respectively, $\$ 1,000, \$ 300, \$ 600$ and $\$ 5,500$; her total winnings being $\$ 42,400$. She was still owned and run by Thomas Kirkman.

The contest between Fashion and Peytona took place at the Union Course on May 13, I845. It was at first proposed to make it a post match and for $\$ 20,000$ a side, but as Fashion was the only horse at the North that could contend with any chance of success against Peytona, her owner deemed it his duty to the public to decline giving his consent to such an arrangement. Subsequently he consented to her running a match against any named horse for $\$ 10,000$ a side, 4-mile heats. Forfeit money, $\$ 2,500$, was put up and on the day before that set for the race the parties met at the Astor House and each deposited \$10,000 with J. Prescott Hall, President of the New York Jockey Club.

Because of the distance between the contracting parties it had required a long time to arrange all the details of the race. One of the men most deeply interested on the side of Fashion had gone over the entire road from New York to New Orleans three times, and a large portion of it twenty times.

Fashion and Peytona, by their conquests in other fields, having added lustre to the fame of the great horses from whom they descended, had now come, in the logical order of events, to try it out with each other in a fifth great match on the ground made memorable by the four great matches of the preceding twenty years. The Union Course was twelve miles from New York and a bridgeless river flowed between them. There was only one railway between East River and the race track and its capacity was limited 

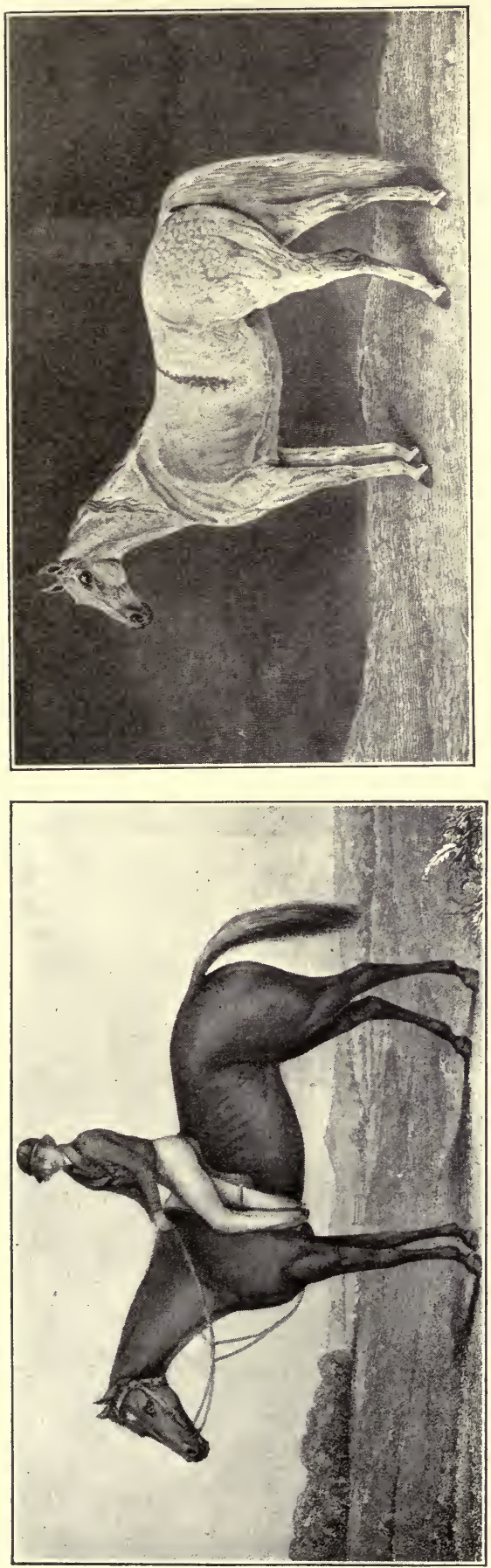

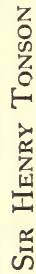

运 

to 30,000 ; the ferries were slow; the roads were dusty; yet notwithstanding these unfavorable conditions more people, it is believed, went to Union Course that day than ever assembled on any other occasion in the United States, before or since.

"Having been present at most of the large gatherings in this country," wrote Col. Webb, of The Courier and Enquirer, "we do not hesitate to say that this exceeded in number any previous assemblage of the People. We were at the Ascot races in England last year when London poured forth its tens of thousands to get a view of Queen Victoria and Prince Albert, the Emperor Nicholas and the King of Saxony. How many people were present on that occasion we do not pretend to say; but we have no hesitation in saying that there was a larger number at the Union Course yesterday."

The "sport of kings" drew a larger crowd than the kings themselves and a queen thrown in.

Some people were wicked enough to insinuate that the annual religious anniversaries in New York City had been prolonged through dilatory tactics so that members of the different societies could attend the race. And the crowd would have been larger still, if the official request of the New York legislature, Whigs and Democrats both joining in, had been granted, postponing the race three days until after the adjournment of the legislature. As it was, Mr. Greeley's Tribune estimated the attendance at 70,000; CoI. Webb said there were between 70,000 and 100,000 and others still put it 120,000 . One thing certain is that the density of the throng prevented all except those perched on high places from seeing the race.

The German turf was represented by one of the barons; Canada sent its leading turfmen and newspaper men; and so did Louisiana, and all points between. AII the 


\section{Making the American Thoroughbred}

leading trainers in the United States were there to see how the thing was done. Tennessee had its quota, among them being Col. Polk, the Chargé to Naples, and John Kirkman.

The amount of money laid out on the match was not so Iarge as might have been expected - according to The Spirit. This was accounted for by the fact that the "Southern party" expected to obtain large odds. "In this," said The Spirit, "they were not only disappointed but it is a singular fact that in every section of the country Fashion was more the favorite than she was in this City. The greatest odds ever offered here were $\$ 1,000$ to $\$ 600$, nealry a month before the race; for two weeks before the race 10 to 9 was the best that could be obtained; it was not until the evening before the race, when every one was 'snatching and eager' to lay out his money that I,000 to 700 was offered and taken on Fashion." Just before the race started bets were made 90 to 100 that Peytona would win the first heat and 100 to 75 that Fashion would win the money.

Other reports were that a half million dollars was staked on the result.

Owing to the great difficulty in clearing the course in front of the stands it was nearly half-past two o'clock before the horses could be started. B. Ogle Tayloe, of Washington City, was selected as a judge by the "friends" of Peytona, and John A. King, by the "friends" of Fashion - President J. Prescott Hall acting as associate and umpire. George L. Schuler, of New York, and J. H. Hellings, of the Camden Course, were the official timers. In drawing for the track Peytona got the inside.

Fashion was the first to make her appearance at the post; she was so much excited by the noise and crowd that she fretted a good deal, and trembled from head to 
foot, as the spectators cheered her. Young Laird, her jockey, was recognized by a purple silk jacket, with white "continuations," and a green velvet cap. "Barney," as Palmer was called, sported a blue velvet jacket, with pants and a cap like Laird's save that the latter had apparently "braved the battle and the breeze" of many a campaign. Peytona had a most determined look, and did not seem in the least "frightened from her propriety" by the tremendous din and uproar around her.

Fashion carried 123 pounds and Peytona II8.

The day was fair, temperature moderate, the course deeper in dust than ever seen before, and such was the crowd that lined both sides of the course the horses were as much shut off from air as if they had run in a vast amphitheatre.

The Spirit of the Times' account of the race follows:

"The Judges and timers took their places and the President gave the signal for the race.

"They went off with a beautiful start, and in an instant were shut out from sight by the crowds on the fences and the tops of omnibusses, of which Iast there were above a hundred on the ground! Through an occasional interstice we could barely descry them and judge of the pace, but beyond this, they were only to be seen as they came up the quarter stretch. It was quite evident from the first, that neither was disposed to make a waiting race of it. To be sure the Judges could see no more of the race than we could - not so much, 'by a good deal,' for that matter! - but what would the readers of the 'Spirit' say if we gave them an excuse like this? Our only chance was to get some good fellow to 'help us out of the snap,' which we effectually accomplished by getting our friend Conover, the trainer, into the stand. He got up on the railing, at the momentary peril of half the bones in his body, and clung by the roof, from which he could command a good view of the horses over the heads of those on the fences and carriages. Side and side the horses went down the back stretch, Laird pulling his mare on the turn, but making play again up the stretch. The ist mile was run in $\mathrm{r}: 54$, Peytona coming through ahead, with Fashion well up. On commencing the 


\section{I4 Making the American Thoroughbred}

2d mile, Fashion forced the pace again, but 'the big mare' shook her off; after ascending the hill at the half-mile post, Fashion again went up and Iaid with her this time, quite through to the stand, coming in lapt on her. This mile was run in $\mathrm{I}: 53$. All the way down the back stretch, Joe gave Fashion no let up; the two were lapped, and near the half-mile post Fashion got such a tickling from Joe Laird's heels, as to drive her up nearly to Peytona's throatlatch! There was no daylight between them as they passed the stand, having run this $3 \mathrm{~d}$ mile in I: 57 ; their rate had sensibly declined on the last quarter of the mile, and the friends of each were sanguine that in a long and severe brush their money was safe. We thought Fashion weakened in this mile; at any rate, she did not appear so full of running, nor go so strong as she ought, or as Peytona seemed to. In the fourth mile, upon getting into straight work on the rear stretch, Laird set to work in earnest, and though Barney felt the utmost confrdence in the nonpareil under him, he was not disposed to throw away a chance. The claret was tapped on both sides, but Peytona's youth, strength and stride, told, at Iast, as did her competitor's, in her match with Boston. Before reaching the hill, Peytona drew out in front, and the heat was all over but the shouting! Laird bottled up his mare around the turn, and tried it on again up the quarter stretch, but it was of no use; Peytona outfooted her, and appeared to win with something in hand, by a length in the clear, though she, as well as Fashion, got a taste of cold steel between the draw-gate and the winning post. The fourth mile was run in $1: 55^{\frac{3}{4}}$, and the heat in $7: 39 \frac{3}{4}$.

"One of our contemporaries is very naturally pleased at 'the respectability of the shout' which greeted Peytona on her winning the heat; indeed the cheering was tremendous from all parts of the course, though the defeat of Fashion 'smote heavily on the hearts of tens of thousands!'

"Both horses cooled out well; Peytona recovered earliest, but before they were brought up for the second heat, she did not appear to have any advantage. How they ever got outside of the course or back again, we cannot say; the course between the draw-gates which are very far apart, is double the width of Broadway, and it was so densely packed, that it was with great difficulty the horses were got back to the stand for the jockies to dismount and be weighed, after the ist heat.

"Fashion's friends were not very much surprised at her loss of the ist heat, and we heard no bets laid as a hedge. We subsequently 
learned, for it was impossible to get across to the Club stand, that I 00 to 70 was the current offer there on Peytona's winning the match. We had good luck in checking the 'devouring flames' of thirst among the select few by whom we were surrounded in the Judges' stand. That 'Good Samaritan' Downing - may his shadow never be less! - whose oysters are the envy of his rivals and the admiration of his customers, spied us and immediately 'understood our case!' He forthwith scrambled over carriages, horses, and the heads of all sorts of people, and by dint of great exertion of tentimes imminently perilous (to the safety of our drink!) finally tossed up to us a goblet and a bottle of iced Cbampagne! More than once we deemed his case would be a sad parallel to that of the 'certain man,' who 'went down from Jerusalem to Jericho and fell among thieves.' We shall not forget Downing until we are 'turned' into something quite as stiff and 'salty' as Lot's wife.

"Just before starting for the $2 \mathrm{~d}$ heat we understood that on the Public Stand they were betting 3,4 and 5 to 1 , on Peytona. We heard, too, that Van Leer was a good deal alarmed about Peytona's heels; she had on very light plates, and consequently was somewhat foot sore. About us the backers of Fashion, consequently, would not hedge their money, but determined to 'let it slide' on 'the old mare.' The backers of time, however, a majority of whom had lost, partially got out by staking their money on Peytona at extravagant odds. Thousands of dollars changed pockets by the fraction of the second in which the Ist heat was run under 7:40; both the official Timers, however, were supported by others, a majority of the watches making the time between $7: 39 \frac{1}{2}$ and $7: 40$. A great number of carrier pigeons were sent up within a minute of the close of the Ist heat, and the result was known in town in ten more!

"Second Heat: Another good start, Peytona leading off as before around the first turn, with Fashion nearly lapt on her. As they were near the quarter post, suddenly a tremendous shout was sent up by the people on the roofs of the stands, in the trees, and on the fences and carriages in the vicinity. 'Fasbion's abead!' shouted Conover to us - an exclamation which quickened the pulse or blanched the cheek of more than one gentleman who heard it. If we could see little of the race during the ist heat our range of vision was now still more circumscribed. Mounted men and carriages were constantly dashing across the freld from point to point, endeavoring to get ' $a$ show' of the horses, for the sides of the course were, in many instances, lined with carriages six or eight deep! Yet Conover had 


\section{Making the American Thorougbbred}

come back after the heat to occupy his old place, and never did 'a right hand man' do better service; from his place, with his head above the roof of the stand, he could telegraph all the movements of the horses, and he really acquitted himself so well that the Judges have the vanity to felicitate themselves (as we do) that they really saw the race! As we have before remarked, Barney pulled his mare out on the hard path, and resigned the deep sand to Laird if he chose to take it which he did, and that so suddenly that many supposed Fashion 'had her sure.' It was a terrible moment! We hardly recollect any circumstance, save the bolting of Blue Dick, which appeared to give such an electric shock to the spectators of a race. We heard people shout in Kentucky when Grey Eagle won a heat from Wagner, and therefore shall not brag on what we can do here; the reader may take our word for it the noise was 'pretty particular considerable,' if not more! They approach the half mile post - 'How are they now, Conover?' 'Fashion's not above a neck ahead!' 'Now Peytona gains a little!' They go up the hill - 'It's head and head with 'em!' 'Fashion still keeps it' round the turn in front of the Iate Club House. Up the stretch they come like twin bullets, Peytona appearing to care nothing for the crowd, to which she ran so close that Barney could have hit the front rank with his whip! They came through Iapt, in $1: 58$, Fashion being a head and shoulders, perhaps, in front. Throughout the whole second mile the contest was equally severe; Fashion could lead by a neck down the straight side, but Peytona's prodigious strength told at the hill, and at this point she invariably gained. The second mile was run in $1: 54$, Fashion coming in a few feet ahead as before. The spectators were hushed by the thrilling excitement of such a contest! Nothing equal to it was ever seen here before! Respiration appeared to be suspended in tens of thousands! - their very hearts seemed to beat audibly, as if viewing some stupendous convulsion of Nature! Fashion, though she could not shake off her dauntless competitor, looked very much like a winner, as she commenced the $3 \mathrm{~d}$ mile. She appeared to be in more force than in the Ist heat; Peytona, however, was apparently not in the least inclined to cut it. In entering on this $3 \mathrm{~d}$ mile Peytona got such a hint from Barney to 'go along,' that she made a slashing burst of it round the first turn to near the quarter mile post, but she did not gain a yard! 'Fashion will beat her!' exclaimed our Mentor, in most lugubrious accents, and between ourselves, 'my friendly,' [the reader,] it would have just 'raised you out of your boots,' to have witnessed the different and changed expressions of the faces 
in the Judges' stand. We felt 'sorry' for several of them - we did. The pace was 'a Iettle too diggin' to Iast much longer, one would have supposed, but then two such animals as Fashion and Peytona never come together but once, on this continent!

"Twenty yards from the quarter post, we heard, 'Peytona's gaining on her!' 'Fashion's ahead a little - about three feet difference!' 'Now Peytona goes up to her!' [This was at the hill.] 'She's head and head with her! - She leads her about a neck!' around the turn, and they swing into the quarter stretch, where Conover could distinguish neither, but we could clearly see Barney's blue jacket, and occasionally catch a glimpse of Joe Laird's. 'Spur your proud coursers hard, and ride in blood!' seemed the order of the day. Each jockey seemed the impersonation of the Centaur - as if himself and horse were one! Each was the PURDY of his party, and each rode as if for his life! It was a masterly exhibition of judgment, coolness, and science. As the horses neared and passed the stand, Peytona had the best of it, but Fashion was lapt on her; they had run the mile (the $3 \mathrm{~d}$ ) in $\mathrm{I}: 55$, thus making the time of the three miles $5: 47$, or within three seconds of the time of the first heat! Fashion let out a link around the first turn of the $4^{\text {th }}$ mile, and at the quarter post was a neck in front - they were side and side down the stretch and at the hill - the same on the turn, so that a blanket would have covered both, and now both are out of sight as they swing into the quarter stretch. 'Who's ahead?' 'Fashion, I guess, but Peytona I hope!' exclaimed some one at our elbow. No one could tell, though the longest man could see best, and both of them, but as the horses were coming 'head on' to the stand, it was impossible to say which had it - indeed it looked like anybody's race, to one who had not a good eye - but before the horses were out of sight Conover remarked, 'I believe Barney's pulling - maybe he's got something left yet!' And so it appeared, for before they reached the draw-gate, Laird drew his whip on Fashion, and gave her the spur at the same time. Barney came on steadily a few feet in front, with an eye all the time on Fashion, but giving his own mare a stab of the spur at every stroke! From the draw-gate to the stand, the contest was as determined on one side, as it was desperate on the other! AIl at once the vast assemblage is quiet - then you hear a shout - it increases as the horses come nearer - it becomes tremendous - your heart somehow gets in your throat - you try to shout yourself - a thrill - a whirlwind of excitement - the winner flies past you - the race is over! Peytona wins the heat (time $\mathrm{I}: 58 \frac{1}{4}$ ) 


\section{I 8 Making the American Thorougbbred}

and race without your hardly seeing daylight between her and her

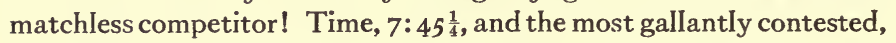
as well as the most beautiful race ever seen in this country."

With this race the long series of North and South matches ended in a blaze of glory.

Both Peytona and Fashion lived until the war period and then went out with the tide that had made them great. Peytona was buried in the garden of her owner, A. Keene Richards, in Kentucky, near the spot where Glencoe had been buried a few years before. 


\section{"THE RACE OF THE OLD KING"}

In The Nasbville Union and American, in 1873, Judge Jo C. Guild first printed his story of "The Race of the Old King." Balie Peyton took exception to that part of the story which dealt with the foul riding; and, to set matters right, Guild had the story reprinted in The Rural Sun, July 24, I873, with this explanatory footnote:

"Since the publication of 'Long Time Ago,' a detailed statement of the facts, merely touching the foul riding, has been furnished by Hon. Balie Peyton, which, in justice to him, is inserted here, as quoted, in place of what I had remembered, written and published. He was fully exonerated then and should be now for the part he played."

After Peyton's death Guild published "Old Times in Tennessee." Through oversight, or because he did not think Peyton's objections material, he put the story in his book, page 88, as originally printed in The Union and American. The story as printed here is copied from The Rural Sun, that part apparently written by Peyton being enclosed in brackets.

Editors Rural Sun: Reflecting upon the old times of Tennessee, I have concluded to give a short sketch of two races of Old King a saddle horse with which Judge Guild rode the circuit when a young lawyer. These races were made and run by Hon. Balie Peyton and Judge Guild in the fall of 1826 . They were schoolmates, young lawyers together and were very firm friends and are yet.

Now as to the first race of the Old King.

Young Guild and Peyton were on the circuit at Carthage, got a few five dollar fees, and left for their residence at Gallatin, taking the races at Hartsville in their route. They rode very fast eighteen 


\section{Making the American Thorougbbred}

miles that morning to get to the races. The OId King was a large sorrel, finely formed, of immense stride and powerful action. He was fatigued by the rapid ride, they not expecting to run him; but so soon as they arrived they were bantered for a mile race with Cook Lewis' horse, who had been in regular training, for $\$ 100$ a side, to carry 100 pounds. The young lawyers accepted the proposition, and the race came off in one hour. They had no time to plate the Old King, so they removed his shoes and cupped him. He made a splendid run and won the match in gallant style.

The young lawyers remained in Hartsville that night to enjoy their victory and the next morning started for Gallatin. Riding six miles they came to Banks' old stand where they found some strangers, and were again bantered for a race of one quarter of a mile for a purse of $\$ 200$ a side. They were conducted to the stable where they found a heavy muscled, compact horse, which they afterwards understood was a celebrated Kentucky quarter-horse, Iately brought to Tennessee. His appearance rather alarmed the keen eyes of the young lawyers. Upon a conference they knew that he was a stranger in the county, and, from his general appearance, that he was a hard customer. But at last they concluded to carry him beyond his accustomed distance and run him 600 yards for $\$ 200$ a side, each to carry 140 pounds, the race to come off in 30 days. The Old King was high spirited, restive, extremely hard to start, as weIl as ride. Balie Peyton, then being the best rider in the state, and of the right weight, the young men fixed the weight with the intent to put up the celebrated rider, Balie Peyton. The forfeit being put up the young lawyers left the courts for a season, and both being good trainers, immediately put the Old King into regular training in accordance with the then improvements in the art.

They established their headquarters at Capt. Jack Mitchell's hotel, Gallatin, where they boarded. All the paraphernalia of a regular training stable was adopted and there is no doubt that they put the horse in as fine condition for the race as the most celebrated trainer could have done.

Their old friend, the eminent John J. White, boarded at the same tavern and had a very fine Pacolet riding horse who had distinguished himself on the turf; and an old bay afflicted with the bighead, who had been turned upon the commons. The young trainers captured the old bay and made him a pack horse to go to mill and to bring hominy and oats. Desiring to give the Old King a quick motion, and to bring his driving muscles into play and to give a rapid and 
212

in

$32 x+x^{2} 2$

ic $x$ c

is a ce

is ic

is 4

i is to

tic ade

tota

ces at at

ci, coo

cc icena

sc, c5 


\section{The Race of the Old King}

quick motion for so short a race, each day they trotted him one hour. The manner of doing this was to place a rider on the Judge's old bay and run him at full speed around a circle, the rider leading the Old King, making him trot, giving him his most rapid stride.

One evening while this was going on the Judge and the young lawyers walked out upon the common. The Judge observed that one horse was going at full speed around a circle, the other following in the rear. He said, "What does that mean? They seem to be going round." At length he said, "Gentlemen, I do believe he is the old bay that the boy is riding in front." They had to admit the fact to the Judge, and endeavor to make the necessary explanations. He kindly remarked, "Now, boys, you may use the old bay moderately to go to mill; but it's too bad to run him around a circle in that way." They faithfully promised to comply with his request, which was done.

The training of the OId King went on satisfactorily.

A few days before the race Guild and Peyton desired to test the powers of their horse and to break him to go off at the word. The only reliable test they had was to run the Old King against the Judge's Pacolet horse. By great kindness he had been made gentle to ride and they knew that the Judge would not consent for him to be run with the OId King. They concluded that they would take them out by the light of the moon and run them 600 yards. Guild rode the Judge's horse and Peyton the Old King. Many were the false starts. Guild would turn the Judge's Pacolet and rush by Peyton on the OId King to get him to start rapidly. At length they got off together. The whip and spur were freely used, and each horse was fully up to his topmost speed; the result was that the OId King beat the Pacolet some 40 yards. This fully convinced the young trainers that they had an extraordinary race horse. They kept their own secrets, pushed their credit to the utmost extension in raising funds, and then borrowed several horses to bet on the race. They resolved to make a spool or spoil a horn.

The day before the race, which was to come off at Cairo, they broke up their stable and with their baggage train slowly moved upon the battle-freld with all the circumstance and pomp of glorious turf racing. They bivouaced upon the battle-field that night and their thoughts were upon the morrow.

Next morning, like the chieftains of old, they looked for omens and signs in the heavens foretelling the result of the coming contest. The approach of the great King of Day was looked for with deep 


\section{Making the American Thorougbbred}

interest - whether his great eye was full and bright or covered with dark clouds. Their horse was a red, bright sorrel; the other was a dark brown. The coming of the sun was without a cloud, resembling the beauty and brightness of the Old King, and indicating success. This gave Guild and Peyton double assurance that victory would perch upon their standard.

Their object was to get odds in the betting, at any rate even bets, as their capital was not very large. In this there was some finessing which is deemed fair on the turf.

They gave out that they had no rider. They weighed one awkward boy and then another. All the time they had their agents outbetting their money and horses, and the hour having arrived to go upon the freld, Guild announced to Peyton that there was no chance for them to procure a rider of the right weight. Then Peyton remarked that rather than there should be a failure he would mount the Old King and ride himself. So the contestants were led upon the field, and Peyton was stripped for the battle.

The Judges were selected for the start and outcome. Guild was not less distinguished as a turner than Peyton as a rider. Guild seized hold of the bit, and many were the false starts, yet he was determined never to let go until the start was a fair one. Young Peyton, with spurs and whip in hand, I saw

"rise from the ground like feather'd Mercury.

"And vaulted with such ease into his seat.

"As if an angel dropp'd down from the clouds,

"To turn and wind a fiery Pegassus,

"And witch the world with noble horsemanship."

[The owner and rider of the Kentucky horse was a famous jockey; possessing so much skill and tactics in quarter racing it was generally conceded that if once ahead the race was his, as he would suffer no horse to pass him. This fame greatly encouraged his backers and was the main consideration which determined Peyton to ride against him.

The race came off over a mile track - no fence on either side starting in a cornfield at the lower turn, passing out of the field through a wide gateway into a dense forest and up a considerable ascent around the upper turn, to the finish.

Peyton drew the inside track - no small advantage, as for two or three feet out it was the firmest ground.

The Kentucky horse had a little the most speed - just enough to enable his rider to exercise his strategy. 


\section{The Race of the Old King}

The horses went off at a dead lock, under the whip for about four hundred yards; the other rider, from the start, pressed King out of his firm track into deep ground on the inside, so that in passing the gate Peyton's knee barely missed the post. Peyton submitted to this foul riding, as he said, because he soon discovered that the horses were so nearly equal in speed that the superior size, strength and game of the OId King placed the result beyond a contingency.

As they commenced the ascent around the turn, the little quarter horse began to weaken, while the Old King, like the iron horse, kept up his lick and was about to pass, when the rider of the other horse, as a forlorn hope, caught the left rein of his bridle near the bit and attempted to force the old horse into the woods, amongst grapevines and paw-paws. Peyton, who was wide awake, perceiving this in time, braced his horse for the shock and gave the rider a sharp cut across the face, saying, "I would have done that before, as you have ridden foul all the way, but I was sure I had you."

Peyton justified the blow and charged the other party with foul riding, as was evidently the case from the tracks of the horses, which was so decided by the judges, of whom Colonel Stepp, of Kentucky, was one.]

As the Old King came to the Judges' stand a victor there was the thunder of battle in his stride and the noise of the tempest in his wing.

While hundreds of voices proclaimed that the Old King was the winner of the purse, there was a rumbling discontent proclaiming foul riding.

In these times it was of the first importance to have good and willing fighters as chiefs of staff in case of emergency. Guild and Peyton had defended them in courts, and were attended with a reliable reserve. Guild saw the difficulty and fight progressing between the riders and, like Roderick Dhu, blew his whistle and his clansmen Johnny Outlaw, Bird Fallice, and others of tried grit, were by his side. They ran 600 yards to the head of the stretch; there they found Peyton had dismounted and was heavily pressed, putting his assailants at bay with his drawn knife. Guild announced to Peyton "Here we come," and perfect order and peace were reestablished.

The judges decided that the Old King had fairly won the purse, and it was so awarded. He was led back to his stable with the triumph equal in noise and feeling to that given a Roman General upon his return from a glorious campaign. 


\section{"A DIPLOMAT IN PIGSKIN"}

Early in the summer of $1868, \mathrm{~J} . \mathrm{H}$. Wallace, author of Wallace's "American Stud Book" and editor of Wallace's Monthly, paid his first visit to Middle Tennessee. For him was in store the usual number of pleasant surprises that mark the coming of all visitors to this favored section for the first time. The first surprise that greeted Wallace was a few hours after his arrival in Nashville.

"While seated in a hotel dining-room," he wrote, "I observed a large and remarkably fine looking gentleman enter the room and cast his eyes over the guests as if looking for some one. He whispered a word to the head waiter near the door, and then started directly towards where I was seated! He was a very large man, of very commanding presence and his whole appearance at once indicated a man of distinction and mark, even among the great men of the day. His face was large and smoothly shaven, with kindliness and good feeling beaming all over it, while there was a merry twinkle playing about under his great shaggy and snow-white eyebrows that told unmistakably of his fondness for a good, hearty laugh. The whole appearance, and especially the face, impressed me as that of a remarkable man; but I had not time for further observation till he was at my table and inquired if I was Mr. Wallace? Upon receiving an affrrmative answer, he gave his hand, and also his name, Balie Peyton. This was a most agreeable surprise, for, of all the distinguished Tennesseans then living, there was no one I was so anxious to meet as the Hon. Balie Peyton. When a boy I had read of him as a politician and statesman in the days of Jackson, and as a leader to the opposition of his administration in the counsels of the nation. At a later period I had read of him as one of the great breeders and race horse men of his generation. It appeared hardly possible that the man who had filled so large a place in public affairs, thirty or forty years before, 


\section{A Diplomat in Pigskin}

should still possess so many of the marks of vigorous manhood, but the 'three score years and ten' sat lightly upon him in a hale and vigorous old age. He explained that he had only five minutes to stay, and improved the time by pressing me to pay him a visit at his home, near Gallatin, to all of which I glady acceded, and indicated the time at two or three weeks from that day."

Wallace's few days at "Station Camp" were, to use his own expression, "literally filled up with racing and political reminiscences of a past generation." One story, especially, had both a racing and a political origin. It was the joint product of Peyton's appointment as Minister to Chili and the great knowledge of all racing matters affected by one of the high ranking secretaries of the Chilian government.

This secretary "kept race horses himself," wrote Wallace, "and was known throughout the country as one of the most successful and accomplished of aIl who frequented and patronized the turf. He was a kind of Napoleon among the racing men of Chili, and some time after Mr. Peyton's arrival in that country he improved an early opportunity to escort the American minister, on a great occasion, to witness a contest between some of the most famous horses of the country. The winner belonged to the secretary, and Mr. Peyton, not being greatly impressed with the racing powers of the Chili horses, made some remark, diplomatically conveying that idea. The secretary at once wished to know if Mr. Petyon thought there were any better race horses in the United States? Mr. Peyton replied, somewhat apologetically, that the American race horse was larger and stronger, could carry more weight, and, he thought, had more speed. The Chilian, in his anxiety to catch what he thought was a novice in racing matters, dropped all the diplomatic formulas and came right to business, forthwith challenging Mr. Peyton to bring on his American horse for ten thousand a side, owners to ride. To this latter stipulation Mr. Peyton demurred, as he weighed one hundred and eighty pounds, and the Chilian only about one hundred and twenty. After a sufficient amount of diplomatic hesitation, however, he accepted the terms, and sent up to his plantation, in Tennessee, for a couple of great, strong race horses that he had bred himself, and knew all about their qualities for genera- 


\section{Making the American Thorougbbred}

tions back. There was a little stir in diplomatic and official circles, as soon as it was known that a match had been concluded between the great racing secretary and the American minister, but the people did not take much interest in it, or treated it as a joke, until the arrival of the American horses, when it became the excitement of the day, and the sporting event of the nation. The original stakes were cut up. The race was to be a dash of four miles, and the great discrepancy in the weights of the distinguished riders, and the possible inexperience of the American, made it a sure thing, in the estimation of the masses, and indeed of the whole Chili people, that the Napoleonic racing secretary must win. There were many foreign vessels in port, particularly English and American, and they were all ready to back the American horse. As a matter of national feeling the Americans would back their representative, and the English, having unbounded confidence in the superiority of the descendant of the English thoroughbred, brought out and invested their guineas most liberally. The other foreign nations took their cue from these two nations, and it was the purse of the foreigners against that of the Chilians. The aggregate amount of stakes was simply enormous. Instead of Mr. Peyton being a novice in racing matters, and not knowing how to ride, as the Chilians supposed, he had a most extensive and successful experience in the saddle. When a school boy, he told me, he had received more whippings for running off from school to ride races, than for all the other causes put together. He was sought for far and near for his skill and judgment as a rider. By this skill he was able to discount a considerable portion of the sixty pounds overweight which he was required to carry.

"At last the day arrived, and the whole Chili people were early assembled to witness and speculate on the great contest between the Chili and the American horse. The sailors were out in force, and all employments were suspended. Notwithstanding the vast amounts that had already been wagered, there were still a few more dollars left, and the foreign element was able to meet and cover them. The track was cleared and the riders mounted; Mr. Peyton, being on a great, strong son of imp Leviathan, dressed in a closely fitting jockey suit, looked the perfection of developed manhood and grace; the secretary, dressed in the style of the country, was mounted on a grey horse of great local reputation for both speed and bottom. Like the horses of the country, he was under size, and had never been tested with a genuine race horse. They got the word from the judges at the first trial, and away they went. Mr. Peyton took a 


\section{A Diplomat In Pigskin}

strong, steady pull on his horse from the start, while the secretary was disposed to hurry the pace. Thus they went, side by side, for about three quarters of a mile, when the great raking stride of the Leviathan began to tell on the little grey, and the secretary did not appear disposed to hurry the pace any more. Soon after they entered on the second mile Mr. Peyton began to discover the Chilian was in trouble, and instead of hurrying the pace he was Iaboring hard to maintain it at the present rate. After half a mile spent in breaking the heart of the little grey, by coaxing him to his best efforts, and yet unavailing, Mr. Peyton began to let his horse extend himself gradually, and after a number of desperate efforts had been renewed, over and over again, by the secretary, to keep up, Mr. Peyton let his horse open to a full, running gait, listening for the footsteps of the little grey, that he might know the effect of this diplomacy upon him. He could distinctly hear the lash of the secretary, and a suppressed oath occasionally, but the sounds of the footsteps became less and less distinct, till, at the completion of the second mile, he looked around to see where his adversary was, and as his eye fell upon him, he was pulling up his horse dead beaten. As soon as the secretary saw Mr. Peyton looking at him he dropped all diplomatic courtesy, and rising in his stirrups and shaking his fist at him fiercely, he shouted at the top of his voice, 'You go to $\mathrm{h}$-I.' Mr. Peyton galloped on the remaining two miles. The foreigners and sailors cheered most vociferously. The Chilians were so greatly astonished they were speechless for a time, and all Chili was bankrupt."

This article, first printed in Wallace's Montbly, late in I875 or early in 1876, was reprinted in The Rural Sun of Nashville, Feb. 17, 1876, from which paper the writer has copied it through the courtesy of Capt. B. M. Hord. Capt. Hord, then editor of The Rural Sun, called Peyton's attention to the article after its re-publication in The Sun, and Peyton stated to him that it was correct. If it had not been correct it is certain that Peyton, who did not hesitate to challenge the statement of a lifelong friend about a youthful escapade of 40 years gone by, would have had something to say of a man who, after accepting his hospitalities, had written falsely 
228 Making the American Thoroughbred

of an event of his maturer years; and of his official career in which he felt a just and honorable pride. With full knowledge of other versions of this incident the writer deems the evidence here stated conclusive of the facts.

Much is heard now about the duty of the United States to uplift and educate the people of other countries. Balie Peyton anticipated this propaganda by threequarters of a century - he lifted the Chilians off their feet and taught them how to win a horse race. That they paid him $\$ 10,000$ for the lesson was wholly aside from the main purpose of the contest, viz.: to establish a reputation for North American talent and blooded stock between the Andes and the Pacific. Nothing has ever happened in Chili that made her people have greater respect for the Monroe doctrine than this exemplification of the Peyton doctrine. As the Chilians jingled their coin into Peyton's coffers they were fully convinced that the United States was a "world power." 


\section{REMINISCENCES OF THE TURF}

\section{IN EIGHT NUMBERS}

From the Rural Sun, Oct. 31, 1872-Aug. 7, 1873

By Balie Peyton 



\section{I \\ GREEN BERRY WILLIAMS BEGINS HIS CAREER}

Green Berry Williams, the oldest living turfman, a resident of Gallatin, Tennessee, is now in the 95th year of his age. Although in feeble health he retains his recollection of distinguished men and horses of the olden time, in a remarkable degree.

$\mathrm{He}$ is the third son of Charles and Celia Williams; one of six children, three sons and three daughters. He was born in the year 1778, on Briar Creek, Burk County, Georgia. His father was a native of Brunswick County, Virginia, and was raised on the Roanoke River, near Eaton's Ferry. His mother, whose maiden name was Wall, was also a native of Virginia. His parents, though neither rich nor distinguished, were in easy circumstances, and, in personal character, were among the most respectable inhabitants of the colony.

Several years before the commencement of the Revolutionary War, Charles Williams and two of his wife's brothers removed with their families to Georgia, where Green Berry was born, as above stated. After the beginning of the war these immigrants suffered greatly. Both the Walls were killed, the dwellings of all were burned, and their personal property and negroes were carried off by the Tories and Indians. Mr. Williams had thus three families to support; with them he returned to Virginia, where he remained till the close of the war, and then 


\section{Making the American Thoroughbred}

again removed to Georgia, where he died, leaving Green Berry a boy.

The eldest son, Noah, was afterward sheriff of Burk County, Georgia.

The father, elder brothers and cousins of G. B. Williams were devoted to horses and owned and raced some of the swiftest quarter nags of that day, when quarter racing was the fashionable sport among the first gentlemen of the South.

It was at this time, when a small boy, that Berry Williams commenced his career as a quarter-race rider, and soon became celebrated as one of the best riders in the country. He rode many distinguished quarter horses: amongst others, Ready Money, a son of the famous Twigg (Goode's), a son of imp Janus. Ready Money never lost a race. On one occasion he made a dead heat, or drawn race, with the celebrated Georgia Bellair. He also rode the distinguished quarter-horse, Hunter's String. Quarterracing at this period was patronized by the first gentlemen of Virginia and throughout the South. We find weIl authenticated accounts of the pedigree and performances of the above mentioned horse, Goode's Twigg, attested by many of the most distinguished turfmen of the OId Dominion, who state that Twigg was a beautiful bright bay horse, heavily made, with a large blaze in his face, and two white hind feet; I4 hands I inch high, very compact, highly formed, and possessed of great muscular power, symmetry, action and strength. He was a quarterof-a-mile race horse of the very frrst class.

His speed was unknown to all his competitors and when equally weighted he was universally successful. He won immense sums of money and vast quantities of tobacco. The only horses that attempted to contend with him in his prime of life were Polly Williams and 
Paddy Whack. He ran many times with both the above horses; and was only beaten once by each of them, which was owing to the weight he carried, 108 pounds to a catch. He beat Polly Williams 8 times out of 9 for 80,000 to 100,000 pounds of tobacco. He also beat Paddy Whack I I times out of 12 for large sums of money and many hogsheads of tobacco. At one time he beat Paddy Whack at Nicholson's quarter-race paths, in Mecklenburg County, Virginia, for 80,000 pounds of tobacco, io feet, with great ease. He had previously beat Paddy two or three times for 30,000 to 50,000 pounds of tobacco. Another race was run between these horses at the same place, in 1786, for 100,000 pounds of tobacco; Twigg carrying 20 pounds extra weight, which race was won by Paddy by 18 inches. All of which, and much more to the same effect, shows the great interest then taken in quarter-racing. These facts are attested by the signatures of John Goode, Sr., Henry Delong, Henry Cradle, Edward Davis, - - Young, Samuel Goode, Jacob Bugg, Samuel Hopkins, M.D., Randal Davis and Thomas Starling, bearing date from 1787 to 1791 .

Uncle Berry inherited his love of horses, made his appearance on the turf as a quarter-race rider and became one of the most successful trainers in America. He continued to train for more than 70 years, passing through the dark ages of the turf - when legitimate course-racing was almost unknown - with a character for integrity and honor without spot or blemish, and he is now beloved by his friends and respected by all who know him.

Pope says:

"A wit's a feather, a chief's a rod

"An honest man's the noblest work of God."

If this be true - and who can gainsay it? - Uncle 
234 Making the American Thoroughbred

Berry occupies a place in the front rank of nature's noblemen. Does not the example of this venerable man demonstrate that a gentleman may participate in the amusement of the turf without lowering his character or corrupting his morals? 


\section{WILLIAMS' VIRGINIA CAREER}

After the successful issue of the Revolutionary War, turf racing was revived in the Southern States and was controlled by men of wealth, intelligence and high social position, among whom Uncle Berry formed his courteous manners and imbibed his incorruptible principles.

Regular courses were established at the principal cities in Virginia, Georgia and the Carolinas. Uncle Berry was associated with the most noted trainers as a rider, or assistant trainer, until about his 19th year, when he removed to Virginia and took charge of some of the most distinguished horses in the Old Dominion. Before leaving Georgia he rode the celebrated mare called Queen of May, beating the renowned Virginia horse, Clitus, 4-mile heats, at Augusta. He afterwards trained and rode Clitus, beating Queen of May the same distance over the same course.

Uncle Berry was quite small until after his 2oth year, but grew to be a man $s$ feet 10 inches in height, weighing I6 5 pounds. He was remarkable for symmetry and activity and muscular power. In Virginia he was first trainer for Hugh Wyllie, of Charlotte County, and in the first campaign won I,340 pounds, Virginia currency - a very successful beginning, considering the small purses which were rarely more than $\$ 300$ or $\$ 400$ for 3 and 4 -mile heats. Before he left for Tennessee, he met on the course some of the most distinguished men of Virginia, among 
236 Making the American Thoroughbred

whom was Col. Wm. R. Johnson, then quite young, who was afterwards known as the "Napoleon of the Turf." Among the celebrated horses trained by Uncle Berry was Marske (Wyllie's), by Diomed, bred by Hugh Wyllie and sold to Hon. John Randolph, for whom Uncle Berry trained him.

He also trained Ball's Florizel, by far the best and most vicious race horse of his day (if not of any day) in America. The temper of this horse was such that no one except his groom dared to enter his stall, unless he was chained up. Uncle Berry ran Marske successfully, and also won three mile heats with Hyperion, at Broad Rock.

Mr. Randolph took so much interest in this horse that he often visited the course during his training, and would sit on a horse bucket and pour out volumes of the rarest horse talk. Uncle Berry says he never met any one who knew so much and talked so well about horses.

Hyperion won his race, 3-mile heats, over the Broad Rock course; Mr. Randolph was delighted, eulogized Uncle Berry and predicted that he would make one of the first trainers in America. He offered Uncle Berry \$I,000 per annum and offered to furnish him a good house and plenty of servants (of whom he owned hundreds), one half of all he might win, and pledged himself to purchase any horse that he might designate in Virginia, if he would go to his farm, take charge of his extensive stud of thoroughbreds and train his colts.

I remarked that it was a most liberal offer and was surprised that he did not accept it.

"Oh, yes," Uncle Berry replied, "I could have made a fortune, but I was afraid of Mr. Randolph; he was given to strange fits of anger. I would as soon have been shut up in the stable with Ball's Florizel, and he unchained, as to have lived on the same farm with Mr. Randolph." 
The most important and interesting races in which Uncle Berry participated in Virginia were a sweepstake and a match, each of 4-mile heats, in which he trained and ran Ball's Florizel at Broad Rock. This stake was run in 1804 , when Florizel was three years old and all his competitors four years old - entrance $\$ 500$. In it were entered Peacemaker, by Diomed, Top Gallant, by Diomed, Lavinia, by Diomed and Amanda, by Grey Diomed (she was the dam of Duroc, sire of American Eclipse). Peacemaker being amiss did not start. Florizel won the race with great ease at two heats. Top Gallant and Lavinia were distanced.

Peacemaker and FlorizeI ran a match over the same course, 4-mile heats, $\$ 5,000$ a side, in 1805 , which was won by Florizel. His owner publicly offered to run him against any horse in the world from 600 yards to 4 -mile heats for $\$ 5,000$ or $\$ 10,000$.

His wonderful speed and endurance have been constantly cropping out in his descendants; among others, Boston, Lexington, Lecompte, Jack Malone, Muggins, Boon, Lightning, Harry Basset, Monarchist, and others too numerous to mention.

In February, I806, Uncle Berry came from Virginia to Tennessee, bringing three thoroughbred race horses Post Boy, by imp Saltram; and Dragon and Henrietta, both by imp Dare Devil. For some years he made his home at the hospitable residence of Capt. William Alexander, near Hartsville, Sumner County, who was one of the most gallant soldiers of the Revolution. He fought at the Cowpens, where he was in the hottest of the hand-tohand conflict with Tarleton's men, who left the marks of their sabres on his rifle, a weapon that was long preserved by his family as a valuable relic.

Soon after his arrival in this state Uncle Berry came 
into competition with the most remarkable man of the age and country in which he lived. Of course I mean Andrew Jackson, who for 20 years stood at the head of the turf. ${ }^{1}$ In subsequent numbers I will give some account of the competition between them, in which accounts will be brought to light some of the most interesting occurrences of the Tennessee Turf.

1 Note By J. D. A. - By way of introduction to Gen. Jackson's sketch of Truxton, copied from The American Farmer of 1829 into The Turf Register, December number, 1833, Editor Skinner of the Register said:

"General Washington and General Jackson are examples of the fondness that great military men have generally entertained for the horse and the sports of the turf. Though equally bold and graceful riders in the field, General Jackson was most successful on the course. The racing annals of the West record his numerous victories; and according to the anecdotes which are told of him, he sometimes intimidated his adversaries by the boldness of defiance, where he might not have won by the speed or bottom of his horse. He owned some of the finest racers of his day: Pacolet, Doublehead, Truxton, the Opossum filly. And it has been said, that though many horses were taken from the South, in the full assurance of overmatching him, he was never beaten in a match on his own ground. Of all the horses that won distinction under his management, the unrivalled Truxton is believed to have been his favorite: Alexander was not more attached to Bucephalus. His system of training was severe, pulling his horse to incredible hard work where his constitution would bear, and his condition demand it." 


\section{SUMNER COUNTY RACES, 1804-05}

Turf racing was introduced into Tennessee about the year 1804. The first race of note of which we have any account was a sweepstake for 3-year-olds, mile heats, \$10o entrance, which came off at Gallatin in the fall of I804, and was won by R. D. Barry's Polly Medley, by Grey Medley; she beating Gen. Jackson's Indian Queen, by imp Diomed; James Cryer's Grand Turk, by Grey Medley, and five others.

This race excited great interest and was attended by the first ladies and gentlemen, who came on horseback from the adjacent counties. Among others were Gen. Jackson, Mrs. Jackson and her nieces and namesake, Rachel Hays, the greatest belle in the country; and Gen. Hall and his beautiful young bride, Polly (the daughter of Capt. William Alexander of Revolutionary memory), after whom Polly Medley was named.

Mrs. Hall, in the 84th year of her age, is still living at the old homestead near Castalian Springs, in defending which her gallant husband, who was as brave a soldier as ever pulled a trigger in the pioneer struggle for independence, had many a desperate conflict with the Indians. This venerable lady retains, in a remarkable degree, the possession of her mental faculties, and has a vivid recollection of this race (which occurred a few weeks after her marriage) and many incidents connected with it. 


\section{Making the American Thoroughbred}

When the horses were brought on the course Mrs. Jackson, pointing to Polly Medley, said, "She is too little to run with the Indian Queen," to which Mrs. Hall (then in her 17 th year and small for her age) replied, "Horses are like people, the smallest are generally the smartest."

When the horses were about to start, a preacher residing in the vicinity bappened to arrive and made inquiries for a stray cow. At the tap of the drum Polly Medley took the track and was soon a considerable distance ahead of her competitors. The preacher, becoming greatly excited,mounted the fence and, waving his hat cried out at the top of his voice, "Look at Polly Medley! Look at Polly Medley! Look! she Ieaves" - with an oath "a blue streak behind her." The enthusiastic divine was arraigned before his church, tried and suspended for a time. I have heard this anecdote related by my father, who was present at the race and a witness on the trial.

The race was succeeded by a splendid ball given by Dr. Barry and his amiable wife, who were famous for their hospitality and sumptuous entertainments. Gen. Jackson, the most graceful dancer and most courtly gentleman of his day, opened the ball with the beautiful bride (Mrs. Hall) as his partner. Mrs. Hall and Mrs. Barry were sisters and they and their families were ever on the most intimate terms of friendship with Mrs. Jackson and the General.

Grey Medley was, I believe, the first ${ }^{1}$ thoroughbred stallion brought to Tennessee. He was bred by Gov. Ben Williams of North Carolina, purchased by Dr. R. D. Barry, brought to Tennessee and made his first season, in the year I800, at the farm of William Donelson, ten miles north of Nashville, on the Gallatin Road.

1 See pages 44, 45, and Addenda. D. 


\section{Sumner County Races}

Grey Medley was foaled in 1791; he was by imp Medley, and had a pure maternal pedigree; he was a small horse not exceeding $\mathrm{I} 5$ hands high and was said to possess a faultless form and great beauty.

The Arabian blood of Grey Medley was conspicuous in the distinguished race horse, Monsieur Tonson, and his three brothers, Sir Richard, Sir Henry, and Champion, Brown Dick, and Gamma and her numerous descendants. These families received several additional strains of Arabian blood through Pacolet (sire of the Tonson's), who was by imp Citizen, he by Pacolet (English), he by Blank, and he by Godolphin; the second dam of English Pacolet was by the Godolphin. Mary Gray, the dam of American Pacolet, was by Tippoo Saib, whose fifth dam was imp Selima, by the Godolphin.

From 1804 to 1810 Lazarus Cotton's gray gelding Greyhound, by Tayloe's Bellair (the best son of imp Medley), was greatly distinguished and considered the best race horse in Tennessee, especially at 3 and 4 -mile heats. He was under is hands high, but able to carry full weight and go the distance.

In the spring of 1805 , at Gallatin, he beat Bompard, Gen. Jackson's Indian Queen, and others, 4-mile heats, at 3 heats.

About this time, at Hartsville, he beat Truxton (when out of condition) mile heats. Maj. John Verrell, who then owned Truxton, came to Tennessee, saw Gen. Jackson and satisfied him that Truxton lost the race from being out of condition, and the General made a match on him against Greyhound for $\$ 5,000$; to be run on the same course, mile heats. Maj. Verrell was interested in the match and trained Truxton, who won the race, beating his game little competitor, an aged horse, and inferior in speed to his large, muscular, young antagonist. 


\section{Making the American Thoroughbred}

No contest on the soil of Tennessee has ever been so exciting or caused so much betting, considering the means of the people, as this race. Hundreds of horses and numerous 640 acre tracts of land were staked on the result. The old pioneers, who were accustomed to quarter-racing, and had witnessed the indomitable game and great success of Greyhound, bet their horses and lands upon him with the utmost confidence. When the race was over there was a general inquiry of, "Will you carry my saddle home for me?" and "Does your horse carry double?"

In the fall of 1805 Capt. Joseph Erwin offered to run his horse, Tanner, a son of imp Tanner, against any horse in the world, 4 -mile heats, for $\$ 5,000$ a side, the person accepting the bet to name at the post. Gen. Jackson accepted the banter and trained 16 horses, Truxton and Greyhound among them. He started Greyhound and won the race at three heats over the Clover Bottom Course.

At the same time and place Gen. Jackson had a match of $\$ 2,000$ a side in cash notes on Truxton, against Capt. Erwin's Ploughboy, 2-mile heats; but Ploughboy being amiss Capt. Erwin paid the forfeit. A misunderstanding arose concerning this last mentioned race, which was the occasion, but not the cause, of the fatal duel between Gen. Jackson and Mr. Dickinson. 


\section{PRESIDENT JACKSON'S ORDERS AND REMINISCENCES}

In the spring of 1834 , while a member of Congress, I was invited by my friend Maj. A. J. Donelson, private secretary of President Jackson, to visit without ceremony the stable of horses then being trained at Washington by himself and Maj. T. P. Andrews of the United States Army, consisting of Busirus, by Eclipse, owned by C. Irvine; Emily, by Ratler, Lady Nashville, belonging to Maj. Donelson, and Bolivia, owned by Gen. Jackson. ${ }^{1}$

I assisted in timing all the "trial runs" of the stable. As the race meeting drew near, Maj. Donelson called to notify me that the last and most important run would take place on the following morning, urging me to be on hand and saying the General and Mr. Van Buren (the Vice-President) would be present.

1 Note By J. D. A. - In a letter written from the White House February 18, 1832, by A. J. Donelson, to Stockley Donelson, this statement appears: "As to the colt training, the proper instructions have been sent to Mr. Steele [overseer at the Hermitage] who will no doubt execute them so far as to give Alexander the means. I do not understand your meaning when you say it won't do to bring them on to Baltimore. If they are promising and worth the price which Uncle [President Jackson] has put upon them and which he has been offered for two of them, I cannot see any difficulty in the way ... and do not fear the consequences of its being known that the President has consented to have his horses trained and raced if there is a prospect of his winning. I can assure you that injury on this score is imaginary, and has long since ceased to be harmful." 


\section{Making the American Thorougbbred}

Galloping out I overtook the party. The General was as calm as a summer morning. On our arrival the horses were brought out, stripped and saddled for the gallop. Busirus, an immense animal, and of prodigious muscular power, became furious and unmanageable, requiring two men to hold him for Jesse, Maj. D.'s colored boy, to mount. As soon as Busirus began "kerlariping" Gen. Jackson fired up, took command, and issued orders to everybody. To the trainer he said, "Why don't you break him of those tricks? I could do it in an hour."

Rarey ${ }^{1}$ could not have done it in a week.

I had dismounted, prepared my watch, and taken my place immediately below the Judges' stand for the purpose of timing. The General and Mr. Van Buren remained on their horses in the rear of the stand - a safe and convenient position, as the quarter stretch was enclosed on both sides down to the stand, no other part of the course being enclosed on the inside. The General, greatly excited, was watching Busirus and commanding everybody. $\mathrm{He}$ said to me, "Why don't you take your position there; you ought to know where to stand to time a horse" pointing to the place I intended to occupy in due time. I toed the mark, lever in hand, without saying a word nobody ever jawed back at Old Hickory when he was in one of his ways.

Busirus was still "kerlariping."

"Hold him, Jesse! Don't let him break down the fence. Now bring 'em up and give 'em a fair start." And flashing his eye from the enraged horse to Mr. Van Buren, who had left his safe position in the rear and ridden almost into the track below the stand, he stormed out, "Get behind me, Mr. Van Buren, they will run over you, sir."

1 A famous horse tamer of that period. 
Mr. Van Buren obeyed orders promptly, as the timer had done a moment before.

This was one of the anecdotes current among the stumpspeakers of Tennessee in the Presidential canvass of 1836 , between Mr. Van, Buren and Judge White, to illustrate Gen. Jackson's fatherly protection of Mr. Van Buren.

Lady Nashville and Bolivia were next brought out, and demeaned themselves in a most becoming manner. The trials were highly satisfactory and greatly pleased the General, whose filly, Bolivia, a descendant of his favorite horse, Truxton, was to run in an important sweepstake at the coming meeting at Washington. He left the course in the finest humor, and on his way to the White House he gave us, in a torrent-like manner, his early turf experience in Tennessee.

He was the most fluent, impressive and eloquent conversationalist I ever met, and in any company took the lead in conversation. Nobody ever seemed disposed to talk where he was. On this occasion I found him especially interesting - going back to the race of Truxton and Greyhound at Hartsville, in 1805 , and coming up to the great match between his horse Doublehead and Col. Newton Cannon's Expectation, which was run about i8 I I over the Clover Bottom Course, 4-mile heats, for $\$ 5,000$ a side, Doublehead being the winner. ${ }^{1}$

1 Note BY J. D. A. - In his racing contests Jackson seems to have been more successful in defeating his enemies than his friends. Newton Cannon was a member of the jury that acquitted Magness (or Magnus) indicted on the charge of murdering William Patton Anderson in Franklin in 1810 . Whereupon Jackson, who had taken an active interest in behalf of the prosecution and had testified for Anderson, informed Cannon that he was a "marked man." In the race referred to by Peyton, Cannon lost all his hard-earned savings and had to begin life anew. In spite of Jackson's "marking" and lifeIong opposition Cannon achieved distinction as one of the strong men of his time. He served several terms in Congress and was Governor. 
He alluded to the intense excitement and extravagant betting on the Truxton and Greyhound race; said that besides the main bet, he won $\$ 1,500$ in wearing apparel, and that his friend Patton Anderson, after betting aII his money and the horse he rode to the race, staked I $_{5}$ of the finest horses on the ground belonging to other persons, many of them having ladies saddles on their backs. "Now," said he, "I would not have done that for the world, but Patton did it, and as he won, and treated to a whole barrel of cider and a basket full of ginger cakes, he made it all right."

He recounted a thrilling incident, also, which occurred at Clover Bottom, after the race of Doublehead and Expectation, which illustrated his maxim that "rashness sometimes is policy, and then I am rash."

"After the race," said he, "I went to the stable to see the old horse cooled off (it was near the proprietor's dwelling), and about dusk, I observed Patton Anderson approaching in a brisk walk, pursued by a crowd of excited men, with several of whom I was aware he had an old feud. I was bound to make common cause with Patton, and I knew that unless I could check them we would both be roughly handled. I met them at the stile and protested against their course as unmanly, and pledged myself that Patton would meet any one of them at sunrise the next morning and give satisfaction, thus delaying them until Patton had passed into the house.

"But the leaders of the crowd swore they intended to kill him, and I saw there remained but one chance for us, and that was to bluff them off. I knew they had no cause of quarrel with me, and that they supposed I was armed. Putting my hand behind me, into my coat pocket, I opened a tin tobacco box, my only weapon, and said, 'I will shoot dead the first man who attempts to cross that 
fence'; and as their leader placed his foot on the first step, I raised my arm and closed the box with a click, very like the cocking of a pistol, - it was so dark they could not distinguish what I had in my hand, - and, sir, they scampered like a flock of deer. I knew there were men in that crowd who were not afraid to meet me or any other man; but, Mr. Van Buren, no man is willing to take the chance of being killed by an accidental shot in the dark."

I am aware that Mr. Patton, in his "Life of General Jackson," represents this tobacco box exploit as occurring in the daytime, at a long dinner table on the race course, Gen. Jackson on the top of the table, "striding tremendous to the rescue of Patton Anderson, wading knee deep in dinner." 


\section{WILLIAMS' TENNESSEE AND MISSISSIPPI CAMPAIGNS}

In the spring of 1806 Uncle Berry made a match of mile heats, $\$ 500$ a side, over the Hartsville Course, with Henrietta against Cotton's Cygent, which he won.

The old men of the neighborhood manifested great sympathy for the young stranger, and predicted that Lazarus Cotton would ruin him.

This was his first race in Tennessee, and I witnessed his last which was run over the Albion Course at Gallatin in 1862.

Shortly after the race at Hartsville Uncle Berry trained a famous quarter-race mare called Sallie Friar, by Jolly Friar, and made a match for $\$ 500$ a side which was run on Goose Creek, near the Poison Knob. Sallie was the winner; she was afterward purchased by Patton Anderson, who ran her with great success.

In the fall of 1806 Uncle Berry won with Post Boy the jockey club purse, 3-mile heats at Gallatin, beating General Jackson's Escape and others. Escape was the favorite and the General and Mrs. Jackson, who were present, backed him freely. Before this race he sold Post Boy to Messrs. Richard and William L. Alexander for $\$ 1,000$ in the event of his winning the race; after this he was withdrawn from the turf.

Here he first met Gen. Jackson and made a match with him on Henrietta against Bibb's mare for $\$ \mathrm{I}, 000$ a side, 2-mile heats, equal weights, - though the General's 
mare was two years older than Henrietta, - to come off in the spring of 1807 at Clover Bottom. The result proved that Uncle Berry underrated the horses and trainers of the Tennessee turf, as the General's mare, a thoroughbred daughter of imported Diomed, won the race.

The General, though deprived of the pleasure of being present on that interesting occasion (having been summoned as a witness in the trial of Aaron Burr at Richmond), showed that his heart was in the race, as appears from a letter to his friend Patton Anderson, dated June 16, and published in Parton's "Life of Jackson," from which I quote:

"At the race I hope you will see Mrs. Jackson: tell her not to be uneasy. I will be home as soon as my obedience to the precept of my country will permit. I have only to add as to the race that the mare of Williams' is thought here to be a first rate animal of her size: but if she can be put up she will fail in one heat. It will be then proper to put her up to all she knows at once."

This is Jacksonian. Not many men would take the responsibliity of giving orders of how to run a race at the distance of 500 miles.

This error of underrating an adversary, especially such an adversary, was a heavy blow to Uncle Berry, from which he did not fully recover until he started Haynie's Maria, mounted by Monkey Simon, against him.

Not long after this defeat he set out to search for a horse with which to beat Gen. Jackson, and purchased from Gen. Wade Hampton, of South Carolina, a gelding called Omar, bringing him to Tennessee. After recruiting his horse at Capt. Alexander's, near Hartsville, he went to Nashville and offered Gen. Jackson a match for $\$ 1,000$ a side, 3-mile heats, according to rules. This the General declined, offering, instead, the same terms as 


\section{Making the American Thorougbbred}

to weight in the former race, in which he was allowed two years' advantage; a proposition which, of course, was not accepted.

Unable to get a race in Tennessee Uncle Berry took his horse to Natchez, Miss., travelling through the swamps of the Chickasaw and Choctaw nations and entering him in a stake, 3-mile heats, \$200 entrance; but his bad luck pursued him and just before the race his horse snagged his foot and he paid forfeit. He remained near Natchez I 2 months and nursed his horse as no other man could have done, until he was perfectly restored to health and in condition for the approaching fall races of 1808 . Writing to Col. George Elliott he urged him to come to Natchez and bring 15 or 20 horses to bet on Omar, and also to bring Monkey Simon to ride him, which Col. Elliott did.

Simon's appearance on the field alarmed the trainer of the other horse who had known him in South Carolina, and suspecting that Omar was a bite, he paid forfeit.

As Simon was a distinguished character and made a conspicuous frgure on the turf of Tennessee for many years it may be well to give some account of him.

His sobriquet of "Monkey Simon" conveys a forcible idea of his appearance. He was a native African and was brought with his parents when quite young to South Carolina, before the prohibition of the slave trade took effect. In height he was 4 feet 6 inches and weighed 100 pounds. He was a hunch-back with very short body and remarkably long arms and legs. His color and hair were African, but his features were not. He had a long head and face, a high and delicate nose, a narrow but prominent forehead and a mouth indicative of humor and firmness. It was rumored that $\operatorname{Simon}$ was a prince in his native country. I asked Uncle Berry the other day if he thought it was true. He replied, "I don't know; they said so, 


\section{Tennessee and Mississippi Campaigns 25I}

and if the princes there had more sense than the rest he must have been one of 'em, for he was the smartest negro I ever saw."

Col. Elliott, speaking of Simon after his death, said he was the coolest, bravest, wisest rider he ever saw mount a horse, in which opinion Uncle Berry fully concurs.

Simon was an inimitable banjo player and improvised his songs, making humorous hits at everybody; even Gen. Jackson did not escape him. Indeed, no man was his superior in repartee.

On one occasion Col. Elliott and James Jackson, with a view to a match race for $\$ 1,000$ a side, a dash of two miles, on Paddy Cary, against Colonel Stepp's mare, consented to lend Simon to ride the mare.

Col. Stepp not only gave Simon $\$$ Ioo in the race, but stimulated his pride by saying they thought they could win races without him, whereas he knew their success was owing to Simon's riding. Somewhat offended at the idea of being lent out, and by no means indifferent to the money, Simon resolved to win the race if possible; and nodding his head said, "I'Il show 'em." The mare had the speed of Paddy and took the track, and Simon, by his consummate skill and by intimidating the other rider, managed to run him far out on the turns while he rested his mare for a brush on the stretches.

On reaching the last turn Simon found the mare pretty tired and Paddy, a game 4-miler, locked with her, and he boldly swung out so far as to leave Paddy in the fence corner. The boy came up and attempted to pass on the inside, but Simon headed him off and growled at him aII the way down the quarter stretch, beating him out by a neck.

Simon could come within a hair's breadth of foul riding and yet escape the penalty. 
252 Making the American Thorougbbred

Col. Elliott lost his temper, which he rarely did, and abused Simon, saying, "not satisfred with making Paddy run forty feet further than the mare on every turn, he must ride foul all the way down the quarter stretch." The Colonel repeated these charges until at length Simon answered him with, "Well, Col. Elliott (as he always called him), I've won many a race that way for you, and it is the first time I ever heard you object to it." 


\section{VI}

\section{WALK-IN-THE-WATER, A REMARKABLE RACER}

Much has been said and written of the tenderness and care bestowed by the Arabs on their favorite horses, but I doubt whether any Arabian since the time of the Prophet ever showed such devotion to his favorite steed, as Uncle Berry to the thoroughbreds under his care. In fact his kindly nature embraced all domestic animals. For many years he resided on a rich productive farm near Gallatin, where he trained Betsy Malone, Sarah Bladen and many other distinguished race horses; raised fine stock and fine crops and proved himself to be one of the best farmers in the neighborhood. He had pets of all kinds - huge hogs that would come and sprawl themselves to be rubbed, and game chickens that would feed from his hand, and follow him if he left home on foot - often obliging him to return and shut them up.

He raised many celebrated racers for himself and others, and so judicious was his system that at the age of two they had almost the maturity of three-year-olds.

His last thoroughbred was a chestnut filly foaled in 1859, by Lexington, dam Sally Roper (the dam of Berry), which was entered in a stake for three-year-olds, $\$ 500$ entrance, 2-mile heats, to come off over the Albion Course near Gallatin in the fall of 1862 . This filly was, of course, a great favorite with Uncle Berry. She never associated with any quadruped after she was weaned, her master being her only companion. At two years old she was 


\section{Making the American Thorougbbred}

large and muscular and very promising; and in the summer of 186I I urged Uncle Berry to send her to the race course (where I had Fannie McAlister, dam of Muggins, and several other animals in training), that she might be gentled and broken to ride. His reply was, "I have been thinking of your kind offer - I know she ought to be broke, but, poor thing! she don't know anything; she has never been anywhere, and has never even been mounted. I am afraid she will tear herself all to pieces." But he finally consented for my colored trainer, Jack Richelieu, to take her to the track. On meeting Mrs. Williams a few days afterwards I inquired for Uncle Berry. Her reply was, "He is well enough as to health, but he is mighty lonesome since the filly went away."

But of all the horses he ever owned Walk-in-the-water was his especial favorite. In the language of Burns he "Io'ed him like a vera brither." He was a large chestnut gelding, foaled in 1813, by Sir Archy, dam by Gondolah, a thoroughbred son of Mark Anthony; and these two were the only pure crosses in his pedigree; yet he was distinguished on the turf until is years old, more especially in races of 3 and 4-mile heats.

I was present when Walk, at i9 years of age, ran his Iast race, of 4-mile heats, over the Nashville Course, against Polly Powell.

Uncle Berry, several years before, had presented him to Thomas Foxhall, with a positive agreement that he would neither train nor run him again; having a twoyear-old in training Mr. Foxhall took up the old horse merely to gallop in company with him, a few weeks before the Nashville meeting.

It became well known that the mare would start for the 4-mile purse, and she was so great a favorite that no one would enter against her. 


\section{Walk-in-the-Water, a Remarkable Racer 255}

The proprietor, to prevent a "walk-over," induced Foxhall to allow him to announce Walk-in-the-water, whose name would be sure to draw a crowd. There was a Iarge attendance, and the game old horse made a wonderful race, considering his age, running a heat, and evidently losing in consequence of his want of condition.

When the horses were brought out I missed Uncle Berry and went in search of him. I found him in the grove alone, sitting on a log and looking very sad. "Are you not going up to see old Walk run?" I inquired. "No, I would as soon see a frght between my grandfather and a boy of twenty," he replied.

In the year 1827, when Walk was 14 years old, Uncle Berry took him and several colts that were entered in stakes, to Natchez, Miss., travelling by land through the terrible swamps of the Chickasaw and Choctaw nations. The colts had made very satisfactory trial runs in Tennessee, but suffered so severely from the journey that they either paid forfeits or lost their stakes; so that Walkin-the-water was the only hope for winning expenses. $\mathrm{He}$ was entered in the 4-mile race of the Jockey Club, and his only competitor was the bay Archy gelding, Blucher, I5 years old, a horse of great fame as a 4 -miler in Mississippi.

Sometime before the race the Jockey Club met and changed the rule, reducing the weight on all horses of is years or upward to roo pounds, leaving to all others their full weight or 124 pounds, 3 pounds less for mares and geldings. On the day before the race was run a motion by Col. A. L. Bingaman to rescind the rule and make the weights equal was voted down.

This extraordinary proceeding would not have been tolerated by the gentlemen who, at a later day, composed that club, but Uncle Berry protested in vain against the 


\section{${ }_{25} 6$ Making the American Thoroughbred}

injustice done him. He however concluded to run Walk, giving his half brother 21 pounds advantage in weight.

Walk had the speed of Blucher, and when the drum tapped took the track with Blucher at his side, and these two game Archys ran locked through the heat, Walk winning by half a length.

The second heat was a repetition of the first, and never was a more tremendous struggle witnessed on a race course - a blanket would have covered the horses from the tap of the drum to the close of the race.

Any man who has watched a favorite horse winning a race, out of the fire and blue blazes at that, can appreciate Uncle Berry's feelings during the terrible struggle.

The horses swung into the quarter stretch the eighth and last mile and Uncle Berry, seeing the sorrel face of his old favorite ahead, cried out at the top of his voice, "Come home, Walk, come home! Your master wants money and that badly!"

After the race he expressed his opinion of the club in no measured terms. Though habitually polite and respectful, particularly toward the authorities of a Jockey Club, he was a man of undaunted courage and ready to resist oppression irrespective of consequences; but his friends interposed and persuaded him to let the matter pass.

When he reached the stables the horses were being prepared for their night's rest, and he made them each an address.

"Jo," he said to a Pacolet colt named Jo Doan that had lost his stake in slow time, "you won't do to tie to. I've always done a good part by you. I salted you out of my hand while you sucked your mammy; you know what you promised me before we left home (alluding to a trial run) and now you have thrown me off among strangers." And he passed on, complaining of the other colts. 


\section{Walk-in-the-Water, a Remarkable Racer 257}

The groom was washing old Walk-in-the-water's legs while he stood calm and majestic, with his game, intelligent head, large brilliant eyes, inclined shoulders and immense windpipe, looking every inch a hero. When Uncle Berry came to him he threw his arms around his neck and said, bursting into tears, "Here's a poor man's friend in a distant land!"

Walk-in-the-water won more long races than any horse of his day. ${ }^{1}$

${ }^{1}$ Noт́ вy J. D. A. - Peter Faggan, called "Cabin Point," was a free man of color known to all lovers of music and dancing from James River to Roanoke, as one who "made the best bow and drew the most interesting bow." Maj. A. J. Davie, then owner of Sir Archy, was one day in the town of Halifax, N.C., and heard Jarrard Weaver ask an officer if he had collected some money due him from Peter Faggan. The officer answered that he had not and had little prospect of getting the money soon; whereupon Davie suggested that Weaver allow Faggan to pay in music. Weaver demurred. Davie next asked the privilege of cancelling the debt by permitting Weaver to breed a highly prized pacing mare he was then riding, to Sir Archy. Weaver agreed to do this; he went that day to Maj. Davie's home at New Hope, bred the mare - and Walk-in-thewater was the produce.

At 3 years of age Weaver's colt won a "corn race" so easily that he attracted the attention of Col. William Wynn, and J. D. Amis, and they, being subscribers to a post stake and having no colt to run, purchased him for $\$ 600$; he won the race. Under the name of Young Timoleon he won many hard fought victories on various tracks from Petersburg, Va., to Charleston, S.C., and was then brought to "the West" by Wade Bynum, and in various hands continued his successful career. He is said to have "travelled farther, run more long distance races, and to a greater age than perhaps any horse in the world." 


\section{VII}

\section{HAYNIE'S MARIA AGAINST THE WORLD}

Haynie's Maria was a most extraordinary race nag at all distances, probably not inferior to any that has appeared in America since her day. She was bred by Bennett Goodman, of Virginia, who moved to North Carolina where Maria was foaled in the spring of 1808 . From North Carolina Goodman removed to Tennessee and, in the fall of 1809 , sold Maria to Capt. Jesse Haynie of Sumner County. She was one of the last of imp Diomed's get, when 30 years of age. Her first dam was by Tayloe's Bellair; second dam by Symmes' Wildair; third dam by imported Othello, out of an imported mare.

She was a dark chestnut, exactly is hands high; possessing great strength, muscular power and symmetry; the perfect model of a race horse.

Maria commenced her turf career at three years of age and ran all distances from a quarter of a mile to 4-mile heats.

In the fall of i8I i she ran a sweepstake over the Nashville Course, entrance $\$ 100,2$-mile heats, beating Gen. Jackson's colt, Decatur, by Truxton; Col. Robert Bell's filly by imp Diomed; and four others; all distanced the first heat except Bell's filly.

This defeat aroused the ire and combative spirit of Gen. Jackson almost as much as did his defeat by Mr. Adams for the Presidency; and he swore "by the Eternal" he would beat her if a horse could be found in the United States able to do it. 


\section{Haynie's Maria Against the World 259}

In the fall of 1812 , over the Nashville Course, Maria won a sweepstake, $\$ 500$ entrance, 4 -mile heats, beating Col. Robert Bell's Diomed mare; a horse called Clifden; and Col. Ed Bradley's Dungannon. (Gen. Jackson was interested in Dungannon.) This was a most exciting and interesting race, especially to the ladies, who attended in great numbers; those of Davidson County with Aunt Rachel Jackson and her niece, Miss Rachel Hays, at their head, backing Dungannon; while the Sumner County ladies, Ied by Miss Clarissa Bledsoe, daughter of the pioneer hero, Col. Anthony Bledsoe, bet their last glove on little Maria.

After this second defeat, Gen. Jackson became terribly in earnest, and before he gave up the effort to beat Maria he ransacked Virginia, South Carolina, Georgia and Kentucky. He was almost as clamorous for a horse as was Richard in the battle of Bosworth Field.

He first wrote Col. William R. Johnson to send him the best 4-mile horse in Virginia, without regard to price, expressing a preference for the famous Bellair mare, OId Favorite. Col. Johnson sent him, at a high price, the celebrated horse Pacolet, by imp Citizen, who had greatly distinguished himself as a 4-miler in Virginia.

In the fall of 1813, at Nashville, Maria won a sweepstake, \$1,00o entrance, $\$ 500$ forfeit, 4-mile heats, beating Pacolet with great ease, two paying forfeits. It was said that Pacolet had received an injury in one of his four ankles.

The General, being anything but satisfied with the result, made a match on Pacolet against Maria for $\$ \mathrm{I}, 000$ a side, $\$ 500$ forfeit, 4-mile heats, to come off over the same course the fall of 1814 ; but Pacolet, being still lame, he paid forfeit.

These repeated failures only made the General more 
inflexible in his purpose and, in conjunction with $\mathrm{Mr}$. James Jackson, who then resided in the vicinity of Nashville, he sent to South Carolina and bought Tam O'Shanter, a horse distinguished in that state. The fall of 1814 Maria won, over the Nashville Course, club purse \$275, 2-mile heats, beating Tam O'Shanter, William Lytle's Royalist and two or three others.

A few days after, over the same course, she won a proprietor's purse, \$350, only one starting against her.

About this time Gen. Jackson sent to Georgia and purchased of CoI. Alston Stump-the-Dealer, but for some cause did not match him against Maria.

The General then sent to Kentucky and induced Mr. DeWett to come to the Hermitage with his mare (reputed to be the swiftest mile nag in the United States), with a view of matching her against Maria. Mr. DeWett trained his mare at the Hermitage. In the fall of 1814 , at Clover Bottom, Maria beat this mare for $\$ \mathrm{I}, 000$ a side, dash of a mile.

In the fall of 1815 Gen. Jackson and Mr. DeWett ran the same mare against Maria, dash of half a mile, for $\$ 1,500$ a side; $\$ 500$ on the first quarter, $\$ 500$ on 600 yards, and $\$ 500$ on the half mile, all of which bets were won by Maria - the last by 100 feet. This was run at Nashville.

The next week over the same course she won a match, $\$ 1,000$ a side, mile-heats, made with Gen. Jackson and Col. E.d. Ward, beating the Colonel's horse, Western Light.

Soon after this race she was again matched against her old competitor, DeWett's mare, for $\$ 1,000$ a side, over the same course (which was in McNairy's Bottom, above the Sulphur Springs), Maria giving her a distance (which was then 120 yards) in a dash of two miles. 


\section{Haynie's Maria Against the World 26r}

Col. Lynch, of Virginia, had been induced to come and bring his famous colored rider, Dick, to ride DeWett's mare.

Before the last start Uncle Berry directed his rider (also colored) to put the spurs to Maria from the tap of the drum. But to his amazement they went off at a moderate gait, DeWett's mare in the lead, making the first mile in exactly two minutes. As they passed the stand Uncle Berry again ordered his boy to go on, but the mares continued at the same rate until after they entered the back stretch, Maria still a little in the rear, when her rider gave her the spurs and she beat her competitor 180 yards, making the last mile in one minute and forty-eight seconds. AII who saw the race declared that she made the most extraordinary display of speed they ever witnessed.

When Uncle Berry demanded an explanation of his rider he learned that Dick, who professed to be a conjurer, or spiritualist, had frightened the boy by threatening that if he attempted to pass ahead of him, until after they ran a mile and a quarter, he would lift him out of his saddle, or throw down his mare by a mere motion of his whip, which the boy fully believed. Most negroes at that time, and some white people in this enlightened age, believed in these absurdities.

The speed of Maria was wonderful. She and the famous quarter-race horse, Saltram, were trained by Uncle Berry at the same time, and he often "brushed" them through the quarter-stretch, "and they always came out locked." Whichever one got the start kept the lead.

Although Gen. Jackson conquered the Indians, defeated Packenham, beat Adams and Clay, crushed the monster bank under the heel of his military boot, he could not beat Maria in the hands of Uncle Berry.

After the last race above mentioned, some Virginians 


\section{Making the American Thorougbbred}

present said that there were horses in Virginia that could beat Maria. Capt. Haynie offered to match her against any horse in the world, from I mile to 4 -mile heats, for $\$ 5,000$.

Shortly after this conversation, meeting Gen. Jackson, Capt. Haynie informed him what had passed, and the General, in his impressive manner, replied: "Make the race for $\$ 50,000$ and consider me in with you. She can beat any animal in God's whole creation."

In March, 1816, at Lexington, Kentucky, Maria beat Robin Gray (sire of Lexington's third dam) a match, mileheats, for $\$ \mathrm{I}, 000$ a side.

The next month she beat, at Cage's Race Paths, near Bender's Ferry, in Sumner County, Mr. John Childress' Woodlawn filly by Truxton, a straight half-mile, for \$I,ooo a side, giving her 60 feet. Maria won this race by 2 feet only.

This was the first race I ever saw and I was greatly impressed with the beautiful riding of Monkey Simon.

After this race Maria was taken by Uncle Berry to Waynesboro, Georgia, where she bantered the world but could not get a race. There were very few Jockey Clubs in the country at that time. In January, I8I7, Maria was returned to Capt. Haynie, in Sumner County, and soon afterward sold by him to Pollard Brown, who got her beaten in Charleston in a 4-mile heat race with Transport and Little John, when she was 9 years old. ${ }^{1}$ Maria carried overweight, ran under many disadvantages and lost the race by only a few feet.

The other day I asked Uncle Berry how he thought Maria would compare with the best horses of the present day. In reply he said:

1 Note By J. D. A. - Up to this race Maria never lost a heat. She was ridden in this race by Samuel Purdy. 


\section{Haynie's Maria Against the World 263}

"If I were forty and Maria four years of age I would not want a greater fortune than I could win with her at Fordham and Saratoga."

He thinks the improvement in training and the condition of the race tracks account for the difference in time of this and former days. He thinks if the horses of the present day were galloped in sweats 16 or 20 miles under 8 or Io Mackinaw blankets, and every morning and evening galloped 4 miles and repeated under 2 or 3 blankets, and ran their races on deep heavy tracks, as formerly, they would make slow time, and very few of them would be seen on the turf at the age of 9 years; and I agree with him.

In old times, in cases of severe fevers, doctors excluded the fresh air and wrapped their patients in blankets, and gave them warm water to drink. The first cargo of Yankee ice brought to New Orleans was thrown into the Mississippi by an order of the Mayor under advice from the medical board.

I believe that it is conceded that Flying Childers and O'Kelly's Eclipse were the fastest horses the world has ever produced; or, in the expressive language of John Randolph, "They were the swiftest quadrupeds that ever appeared on the earth."

These two horses were the "diamonds of the desert" - the pure fountains with which we are delighted to connect our thoroughbreds by the unbroken links of an extended chain.

Note By J. D. A. - Although Peyton's extended pedigree of Maria includes matter that has already been given in this volume, it is retained, unabridged, as a striking illustration of the way the thoroughbred was made, and as a convenient source of information in detail about the blood of what is believed to have been the best racer that ever circled a track in Tennessee. 


\section{Making the American Thorougbbred}

The third dam of her (Maria's) sire, imp Diomed, was by Flying Childers, and he by Darley's Arabian. (I) The seventh dam of Diomed was by Spanker, he by young Marske, he by Marske (sire of O'Kelley's Eclipse), he by Squirt, he by Bartlett's Childers (own brother to Flying Childers). (2) Diomed was by Florizel, whose third dam was by Flying Childers. (3) Florizel was by King Herod whose fourth dam was by Darley's Arabian. (4) The dam of Herod was by Blaze and he by Flying Childers. (5) The dam of Diomed was by Spectator whose third dam was by Darley's Arabian. (6) The second dam of Diomed was by Blank, whose dam was by Bartlett's Childers. Making seven courses of Darley's Arabian through Diomed, three of which are through Flying Childers and two through Bartlett's Childers.

The dam of Maria was by Tayloe's Bellair, son of imp Medley. Medley's fourth dam was by Bartlett's Childers. (I) Medley was by Gimcrack, and he by Cripple, whose second dam was by Flying Childers. Medley's second dam was by Snap, he by Snip, and he by Flying Childers.

Making three courses of Darley's Arabian through her dam, two of which are through Flying Childers and one through Bartlett's Childers.

Making in all ten crosses of Darley's Arabian in Maria's pedigree, five of which are through Flying' Childers and three through Bartlett's Childers.

Maria has the following crosses of the Godolphin Arabian:

The second dam of Diomed was by Blank and he by the Godolphin. (I) Bellair was by imp Medley, he by Gimcrack, he by Cripple and he by the Godolphin. (2) The second dam of Bellair was by black Selima, by imp Fearnought and he by Regulus, the best son of the 


\section{Haynie's Maria Against the World ${ }^{26} 5$}

Godolphin. (3) The third dam of Bellair was imp Selima by the Godolphin.

If the imported mare ${ }^{1}$ to which Maria traces could be identified she would probably add several additional crosses of these famous Arabs.

For the performances of Maria I have relied mainly upon her memoir published in the sixth volume of the "American Turf Register," which was written by Judge Thomas Barry, who obtained the facts from Capt. Haynie in his lifetime, which are corroborated substantially by Uncle Berry.

1 Bruce says she was Gen. Thomas Nelson's imp Blossom by Sloe (son of Crab), dam by Regulus. See Bцossom, this volumeJ. D. A. 


\section{VIII}

\section{TENNESSEE OSCAR, A HORSE WITHOUT A RIVAL}

Bay colt, Oscar, foaled in spring of 1814 , bred by Rev. Hubbard Saunders, of Sumner County, Tennessee, stood without a rival on the Tennessee turf in his day.

He never paid a forfeit nor lost a heat; nor did he ever meet a competitor able to put him to his top speed.

His pedigree is not only pure, but rich and choice.

He was got by Wilkes' Wonder, dam Rosey Clack by imp Saltram; - Camilla by Symmes' Wildair, the best son of imp Fearnought; - Minerva by imp Obscurity; Diana by Clodius; - Sally Painter by imp Sterling; imp Silver by Belsize Arabian; - by Croft's Partner; - Sister to Roxana by Bald Galloway; - by Akaster Turk; - by Leeds Arabian; - by Spanker.

This pedigree, in the language of my late friend, Rev. Hardy M. Cryer, "is pure as the icicle which hung at the north corner of Diana's Temple."

Oscar was a dark bay of uniform color with black points, full i 5 hands, 3 inches high, owned and run by that hightoned gentleman, Dr. Roger B. Sappington, of Nashville. He was a horse of commanding presence, possessing great power, especially in the shoulders and chest, in which he resembled the lion; high, oblique withers; short back; prominent hips; hindquarters rather light when contrasted with his shoulders and chest; stifles and hocks excellent, and limbs superior; hind feet well under him; with a head, 


\section{Tennessee Oscar, a Horse without a Rival 267}

eye and windpipe which could not be surpassed. $\mathrm{He}$ reminded me of Uncle Berry's answer to my question about the head, limbs and action of Ball's Florizel; he said, "his head was all mouth and nostrils, and he could stand with all his feet in a wash tub."

Oscar, with greatest ease, won his first race, a sweepstake, in October, 1817, over the Nashville Course, 2mile heats, \$1 oo entrance, beating Mr. James Jackson's McShane (by imported Eagle out of his imported mare, Virginia, by imported Dare Devil), and Dr. Butler's splendid filly by Pacolet. The next day he walked over the course for the Club purse.

In May, 1818, he won, over the same course, a Jockey Club purse, 4-mile heats, beating with ease Gen. Jackson's Gun Boat, by Pacolet. Gun Boat was withdrawn after the first heat.

In October, I8I8, over same course, he won the Jockey Club purse, 4-mile heats, beating with ease, at 2 heats, Mr. Morton's horse by Potomac and Col. EIliott's (Uncle Berry's) horse by imported Whip. This Whip colt belonged to Uncle Berry; his history is as follows:

Uncle Berry volunteered in Capt. John W. Byrrns' light horse company early in the Creek War and served out his term under Gen. Jackson, for which he now is, and has been for about 12 months, in the receipt of a pension of $\$ 96$ per annum, payable quarterly. He commenced to receive this pension, under the late act of Congress, in the 95th year of his age. He said to me the other day: "I am sorry the Government don't pay it all at once, for twenty-four dollars won't buy anything, and it is always gone before the next payment arrives."

When his term of service expired he was about to revolunteer, but Col. Elliott, who was then in command of a regiment in the army, persuaded him to return home 


\section{Making the American Thoroughbred}

and look after the women and children and blood-stock, which he reluctantly consented to do.

After spending sometime in Tennessee he visited a friend, CoI. Faulkner, of Garrard County, Kentucky, who invited him to examine a lot of two-year-old colts, some of which he contemplated entering in a sweepstake to come off the ensuing fall.

On returning to the house, Mrs. Faulkner inquired of Uncle Berry what he thought of her colt, to which he replied: "I consider him, Madam, the best of the Iot," at which she was very much gratified, and begged that he would enter, train and run the colt in the stake, to which he consented and won the race with ease.

He purchased this colt of Mrs. Faulkner, brought him to Tennessee, where he won several races, and was entered by Col. Elliott in the 4-mile race against Oscar, as above stated.

It was about the time of Oscar's appearance on the turf that the first Jockey Club was established at Nashville by the most distinguished men of Tennessee, amongst them Gen. Jackson, Col. Ed Ward, Gen. CarroII, James Jackson, Dr. Sappington, Dr. Shreby, Dr. McNairy, Dr. Butler, William Williams, Colonel Elliott, Newton Cannon and other leading citizens of the State.

During the absence of Col. Elliott and Uncle Berry, Dr. Sappington employed Monkey Simon to ride for him, and when the race just above mentioned came off, Simon rode Oscar against Whip, the latter owned and run by his old friends and favorites, Col. Elliott and Uncle Berry. Some uneasiness was manifested by the friends of Oscar who was high strung and difficult to control, lest Simon should suffer him to exhaust himself early, and thereby lose the race. This suspicion was altogether groundless, for Simon always rode to win, if possible; 


\section{Tennessee Oscar, a Horse without a Rival 269}

if he had a weakness it was in being too eager for success in a close contest.

At the tap of the drum Oscar went off under a tremendous head of steam, and, in spite of all Simon's exertions to restrain him, was soon 50 or 60 yards ahead, which served to increase the doubts of Simon's fidelity.

Dr. Shelby dashed across the field and ordered Simon in a most peremptory tone to hold his horse, to which Simon replied, in his characteristic style, "You d-d fool, don't you see his mouth is wide open."

And Simon would have made the same reply to Gen. Jackson under the circumstances. The General said to Simon on one occasion just before the horses started in a very important race, "Now, Simon, when my horse comes up and is about to pass you, don't spit your tobacco juice in his eyes, and in the eyes of his rider, as you sometimes do"; to which Simon replied, "Well, Gineral, I've rode a good deal agin your horses, but (with an oath) none were ever near enough to catch my spit."

On another occasion, after Maria had beaten the General's favorite, Pacolet, and when no friend dared to take a liberty with him, Simon, meeting him in a large crowd, said: "Gineral, you were always ugly, but now you're a show. I could make a fortune by showing you as you now look, if I had you in a cage where you could not hurt the people who came to look at you."

Many years ago I was riding on horseback with Col. Elliott to the Nashville races, and when we reached a point about one mile from the ferry at Nashville, on the Gallatin Road, he observed:

"Here is the place where negroes were annually hired in old times and where I have often hired Simon, who, on account of his deformity and dissipated habits, usually cost me from twelve to fifteen dollars per annum. 
"On one occasion Col. Robert C. Foster, guardian of the minor children to whom Simon belonged, conceiving it to be his duty, bid against me, and ran Simon up to thirty dollars - the then price of a good field hand.

"I concluded to drop Simon on the Colonel's hands and take the chance of hiring him privately. Simon watched the bidding with the deepest interest, as he was most anxious to remain in the stable and enjoy the fame and emoluments of riding Haynie's Maria and other distinguished winners. When I indicated that I would bid no more, Simon turned to the Colonel and said in his peculiarly sarcastic manner, with his head laid back and one eye closed, 'Colonel Foster, by G-d, I am not a-selling, but a-hirin' for only one year.' The Colonel, who was a man of high spirit and great dignity replied, shaking his cane at Simon, 'You impudent scoundrel, do you know who you are talking to?' Simon with the most aggravating coolness, replied,'I think I do, and if I am not mistaken you are the same gentleman who made a small 'speriment for Governor once"" - alluding to a race the Colonel had made for Governor under very unfavorable circumstances, in which he was badly beaten. The witticism of Simon created much mirth, amidst which Colonel Elliott got him at the next bid.

The purses at that period were unworthy of the attention of so superior a horse, and Dr. Sappington had neither the means nor disposition to travel or run him for heavy matches; Oscar was therefore, when sound in all respects and in the prime of his racing career, withdrawn from the turf and died at I I years old, the property of General R. Desha and Mr. Isaac Bledsoe, of Sumner County, where he left some fine running stock, although he never served more than two or three thoroughbred mares. 


\section{APPENDIX}

\section{LetTers from ANDrew JACKSON to Rev. Hardy M. CRYer}

A dozen or more letters written by Andrew Jackson to Rev. Hardy M. Cryer are in possession of the Tennessee Historical Society. Some of them were written before Jackson was elected President and others while he was President. These Ietters add confirmatory evidence to the generally accepted view that, as a rule, Jackson's enemies were all bad, his friends all good; that toward "neutraIs," the young, "the rank and file" and his employees, he was kind, courteous and considerate; never puffed up with pride nor affecting superiority over his friends and neighbors among the "plain people."

These letters show, aIso, that Jackson always, - even while encompassed by his enemies in Washington, - directed the details of work at the Hermitage; and that he was nearly always hard pressed for money and beset with other aggravations of farm life that tend to increase the population of cities.

AII of the letters are in Jackson's handwriting, and the portions here used are precisely as he wrote them. They relate, mostly, to the breeding of Jackson's mares to Cryer's horses, and kindred transactions.

The first letter of the collecton, written from "Gallatine" - as Jackson spelled it - "Saturday evening Aug. 18, 1827," shows that Jackson had ridden out to see Cryer, 26 years his junior; when, if the truth were known, there were many men and boys grouped around him, any one of whom would have felt honored with an order to gallop out the Long Hollow pike and tell the young minister that the hero of New Orleans would be pleased to see him in the city. Jackson was great enough to mix with the common herd and do as ordinary people. In concluding this letter he wrote: "I had a great wish to see you and hope you \& your lady can pay us the promised visit next week."

On March 6, I828, while Jackson's campaign for the Presidency was in full swing, he sent a mare to Cryer's farm; and a letter in which he promised seven other mares to Stockholder and Sir William, then at Cryer's. In this letter Jackson observed: “From the scarcity of money and the high prices at which fine horses stand, I have almost determined to abandon breeding horses and turn my attention to 
mules." He concludes: "Mrs. J. unites with me in kind respects to you and Mrs. Cryer \& believe me your friend" - etc.

By the same person that took two mares to Sir William, on May 3, 1828, Jackson wrote despairingly of the hard times and prospects for better; nobody in the Hermitage neighborhood had the money to buy Cryer's "negro wench and children"; Jackson, himself, had been forced to go to bank to get money to pay current expenses; he regretted, therefore, that he was unable to help Cryer; but added consolingly: "My Dr. Sir do not lose heart, - you have friends \& if they have not money, they have credit \& property \& will aid you in the time of need, as much as they can." The usual conclusion: "Mrs. J. joins me in kind salutations to you and your family."

Here is one in full:

“My Dr Sir

"H-ge May IIth. 1828"

"Your note of yesterday by your son was duly recd with the mare and coalt - it was too late for his return yesterday, I detained him until this morning - it is now raining, \& if it holds up in time, he will be with you this evening, should it continue to rain, I will detain him until tomorrow.

"I have the unpleasant intelligence to communicate, that this morning was found dead, the mare brought down yesterday by your son-Having company when she arrived, I only saw her at a distance, \& Charles when he put her away did not discover her being unwell - I suppose she must have died with the botts - "He that giveth hath the right to take away," and at those things I never repine - I have lost in the last 18 months, at least $\$ 3000$ woth of horses, \& my favorite gray mare, has been twice ill with the grubs, since she came from the horse-

"I hope I shall have the pleasure to see you soon, at the Hermitage therefore shall not now reply to your former letter, barely observing, that the honest and upright man, as long as humanity, virtue, \& charity exists in society, must always find friends in the day of need, - when this ceases to be so, then indeed, has the social compact failed to be what divinity intended by the wisdom of its institution.

"My health is better - I have had a severe attack, but hope in a few days to regain my usual strength, when pressing business will compel me to Alabama for a few days - before I get out, I would be glad to see you.

"With the kind salutations of Mrs. J. \& myself to you \& your family believe me your

friend

The Revd. H. M. Cryer -

Andrew Jackson

In 1830 President Jackson and his kitchen cabinet were deeply engrossed in rewarding the victors and in trying to prevent a dissolution of his official cabinet; but these perplexing matters did not 
prevent him from occasionally stealing away from Duff Green and Amos Kendall to make himself comfortable in his slippers, with his corn-cob pipe, - if tradition be true - and writing to his young clerical friend down on Station Camp Creek about "my gray stud colt, Bolivar." Jackson considered Bolivar "one of the purest blooded horses in America" - "better than any that can be got in Virginia now" - and had great hopes of him. On Jan. 10, 1830, he wrote, approving some action Cryer had taken with reference to Bolivar, and, continuing, said of him:

"I would like to get Col Elliots opinion of the propriety of training, and running him in the spring, if he tbinks well of it, - I will give him fifty dollars for training him, and when he makes the experiment, if he chooses to enter him for his own benefit, he may do so; if not I will pay the entrance, \& run him for the benefit of my son, if Col Elliot thinks his situation \& wind will justify the experiment - I am of the belief, that by nature, if his breathing had not been injured, he was one of the frrst runners ever owned in America Dunwody by neglect destroyed him as a runner \& ruined my Oscar filly also as a runner. Consult Col Elliott in wbom I bave every confidence, whether it is prudent to try him again upon the turf - if he says he will train him, \& think he can run him in credit, let him be placed wheresoever the Col may direct, say on my own farm, \& treated as he may desire until the proper time for him to take him for training. If he advises him not again to be trained, then, Sir, you will either send him to my farm or place him at a stand that you may select, advertising him at fifteen Dollars payable within the season, or twenty out \& in proportion the single leap \& insurance."

On Feb. 28, 1830, Jackson wrote another letter about Bolivar and told Cryer to apply certain money to his own use "until it may be more convenient for you" to repay it, or until "my wants may require it."

On Jan. 17, 1832, just after pulling out from under the influenza; and from under the surgeon's knife, inserted into his Ieft arm to remove a Benton slug, deposited 17 years previous; and while still wrestling "with one of the most factions corrupt oppositions in the secrete sessions of the Senate that ever disgraced any nation," Jackson wrote to "My Revd. Friend:"

"I thank you for your friendly offer of an interest in your fine Horse. But Andrew is now married, and I mean to throw the care of the farm on him, I shall never more pester myself with this worlds wealth - My only ambition is to get to the Hermitage so soon as the interest of my country and the will of the people will permit me, and there to set my House in order \& to go to sleep along side of $\mathrm{My}$ Dr Departed Wife." 
He authorized Cryer to settle a debt owing from Andrew Jackson, Jr., to "my friend Mr. Cotton," stating that he "could not rest until justice was done" Cotton. That matter settled, he added, "I give over any attention to colts and the turf," but intended "keeping up my blood stock upon my farm" and "will be happy to hear the blood of your fine horse Crusader, his size and figure." He then concludes:

"I will write you again soon, if I can, shall expect to hear from you - With a tender of my best wishes to your lady \& family \& the request that you will kiss little Rachel for me believe me your friend

Andrew Jackson"

“P. S. The Vice President is wielding his talents and showing his vindictive feelings as it regards Van Buren - But two votes he has given in Secrete Session, it is said by some of his former friends, has sunk him beneath contempt in the Senate.

"The Revd. H. M. Cryer"

Before going to South Carolina to buy Crusader, Cryer, in September, 1831, had obtained a letter of introduction from the President to Colonel Singleton, Crusader's owner. With this letter the President sent Cryer an urgent invitation to visit him at the White House.

Soon after the death of Mrs. Cryer it appears that the minister wrote to the President of the United States for advice about a second marriage. The President answered then as the President would answer now, and Cryer did accordingly. On Feb. 10, 1834, Jackson, then engaged in the great Bank Deposit fight, took time to express his approval, in tenderest terms. And then branching off on the old - yet ever new - subject of race horses, he showed signs of having expunged from the record his resolution to quit the turf. $\mathrm{He}$ asked Cryer to be on the lookout for a certain trainer and to call at the Hermitage, examine certain colts, and give his opinion of "their appearance \& promise for the turf." He then concludes:

"I have great confidence in my citizen as a stock horse and wish to bring his colts early on the turf to make him valuable as a brood horse - look at him and give me your opinion.

"Present me kindly to your Lady \& family \& kiss little Rachel for me $\&$ believe me Yr friend

The Revd. H. M. Cryer -

Andrew Jackson

"P. S. I send for your perusal Mr. Rives speech on the removal of the Deposits - The mamon of corruption is chained \& will be destroyed. A. J." 


\section{ADDENDA}

A

The illustration of Great Britain in this volume is from a photograph; the illustrations of Herod and Matchem are from steel prints obtained from Cassell \& Co. of London; all the other illustrations of horses are reproductions of steel prints that appeared in various books and magazines of the long ago. The likeness of Lexington is copied from "Frank Forester's," "The Horse of America." The likenesses here shown of Sir Archy, American Eclipse, Boston and Glencoe, appeared first in "Forester's" history; and Iater in Wallace's Stud Book, from which they are copied. The Spirit of the Times, at a cost of more than \$500, printed a steel engraving ( $12 \times 15$ inches) of Leviathan, made from a portrait now in possession of Mr. Alex Jackson of Mobile; the illustration of this horse here presented is a copy of this steel print. AII the other half tones of horses are made from steel prints that appeared in The Turf Register.

The names of the horses, painters and engravers, in the order stated, were:

SIR CHARLES (Cover Design): A. Fisher; J. Cone. THE GODOLPHIN ARABIAN: Stubbs; Cone. THE DARLEY ARABIAN: D. Dalby; J. Cone. FLYING CHILDERS: Sartorius; Longacre. MATCHEM: Eng. by J. Scott after original by W. Webb. O'Kelly's ECLIPSE: Stubbs; F. Butler. HIGHFLYER: Boulbee; Francis Humphreys. GIMCRACK: Stubbs; Longacre. CITIZEN: Clifton Thompson; Longacre. DIOMED: Cook; Longacre. SIR ARCHY: A. Fisher; Capewell \& Kimmel. TIMOLEON: T. Campbell; Bannerman. AMERICAN ECLIPSE: A. Fisher; Capewell \& Kimmel. LEVIATHAN: E. Troye; A. L. Dick. GLENCOE: C. Hancock; J. C. Buttre. BOSTON: H. DeLattre; Capewell \& Kimmel. PRIAM: B. Marshall; copied by W. W. Bannerman from original by Romney. FASHION and Joseph Laird: William Wilson; A. L. Dick. GREY EAGLE: E. Troye; A. Halbert. WAGNER and Willis, the Jockey: E. 


\section{Making the American Thoroughbred}

Troye; A. Halbert. JOHN BASCOMBE: E. Troye; F. Humphreys. LEXINGTON: I. Maurer; J. Duthie. Herod not given.

The likeness of Andrew Jackson comes second-handed from a photograph of a portrait presented by Jackson to Mr. and Mrs. Thomas Martin of Davidson County, Tennessee in December, 1814, while they were in New Orleans. This portrait was regarded as an excellent likeness of Jackson.

The half-tone illustrations here presented were made by the Capitol Engraving Co., of Nashville.

\section{B}

In 20 years the get of MARSKE won $£_{75}, 000$. SLOE, son of Crab, was never beat. POT8OS won 31 races. SIR PETER TEAZLE, according to Osborne's Hand Book of the English Turf, sired 350 winners of prizes amounting to 126,726 sovs., besides 34 cups. Imp BUZZARD (in England) sired 189 winners of prizes amounting to 52,553 sovs., besides 6 cups. SELIM, son of Buzzard, sired 152 winners of prizes amounting to $£_{55,253}$, besides the Whip and 9 cups. Died 1825. RUBENS, brother to Selim, sired $23 \mathrm{I}$ winners of $£_{73,03} \mathrm{I}$, besides 33 cups and one BowI. Died I829. Matchem's best son, CONDUCTOR, won 14 races and sired 52 winners of prizes worth $£_{21,999 .}$. TRUMPATOR, by Conductor, won 8 of 14 races and sired 207 winners of prizes worth $£ 65,74 \mathrm{I}$, besides cups, etc. Died in 1808 , aged 26. IMPERATOR, by Conductor, won 13 races and sired 31 winners. SORCERER, by Trumpator, won 16 races and sired 180 winners of prizes worth $£ 82,708$, besides 6 cups. Sorcerer's son, SOOTHSAYER, during his brief career in the stud in England, before going to Russia, got 83 winners of 29,286 sovs. Sorcerer's son, COMUS, winner of the Claret in 1813 , and 9 other races, sired 222 winners of prizes worth $£_{54,892}$, besides 3 cups. WHISKEY, by Saltram, sired 148 winners of prizes worth more than $£_{42,4}$ I6. TRAMP, by Dick Andrews, won 9 races and was regarded as the stoutest horse of his time. He sired 161 winners of 67,501 sovs. In a sketch of Tramp copied in The Turf Register in June, 1836 , from the old London sporting magazine, the amount won by Tramp's get is the same as here stated on the authority Osborne, but the number that won this amount is said to have been 91 , and their names are given. 
On the English turf, in 1840,5 of imp BELSHAZZAR'S get won 9 prizes; 4 of imp GLENCOE'S won 9; I7 of imp PRIAM'S won 55; 4 of imp ROWTON'S 35; 5 of ST. PATRICK'S won 15; I I of VELOCIPEDE'S won 22; 6 of SULTAN'S 2 i ; 5 of STUMPS' 10; 7 of PLENIPOTENTIARY'S 12; 9 of MULEY'S 19; 9 of ACTAEON'S 19; 6 of CAIN'S 16. LITTLE WONDER, by Muley, won the Derby in 1840. Crucifix, one of the three Oaks winners got by Priam, produced SURPLICE, who won the Derby and the St. Leger in 1848 .

\section{C}

Imp JUNIPER, by Babraham, won 14 of 18 races and ran second in the four he lost.

GIMCRACK, a winner, himself, of 28 of 37 races, passed his winning abilities on to succeeding generations in America, through his sons Medley and Clockfast. Medley, like Sir Archy, could get a winner on any sort of a thoroughbred mare - and some times on mares that were not thoroughbred. Clockfast, who was imported six or seven years later than Medley, was out of a mare by Regulus. Lady Lightfoot, Black Maria, Tuckahoe and Boston were among Clockfast's distinguished descendants.

Considering their careers both on the turf and in the stud the contest for first honors among all Sir Archy's sons, among breeders of their day, lay between BERTRAND and SIR CHARLES.

Up to March 3, 1827 BERTRAND had won 13 of 15 races, 6 of which were of 4 -mile heats, 3 of 3-mile heats. His two defeats were in 3-mile heat races. His contest with Aratus and Creeping Kate, 3-mile heats, at Charleston, was one of the most famous in the history of the turf. Aratus and Creeping Kate "combined" against Bertrand. In the first heat Kate ran so as to hold her distance only, leaving Aratus to take the first heat, which he did by half a length, in a desperate struggle in which he and Bertrand were never separated a length. In the second heat Aratus ran so as to hold his distance only, leaving Kate to take the heat, which she did by half a length. It was now up to Bertrand. He took the track and kept it, beating Kate by a length, Aratus again running behind to keep himself fresh for the next heat. Kate was then withdrawn and Aratus came forward to finish Bertrand who had run under 


\section{Making the American Thorougbbred}

whip and spur in all three heats. Aratus' rest during two successive heats enabled him to take the lead, Bertrand hanging to his haunches. "In the second round Bertrand made a desperate rush and ran locked with Aratus for near half a mile. Expectation ran on tiptoe at this juncture; and when at the turn Bertrand was compelled to fall in, all feared the result. On the third and last round, at the same point, Bertrand made his last push and succeeded in passing his antagonist and taking the track. Aratus now hung on his haunches until the last quarter, when the great and last effort was made, and the heat was won by Bertrand by half a length." Time $5: 48-5: 47-5: 52-5: 53$. Twelve miles, 23:20; which was half a minute better than the 12 miles (at three heats) of Eclipse and Henry, three years previous. Aratus was by Director (by Sir Archy), dam by imp Sir Harry; Creeping Kate by Sir Archy, dam by Potomac; Bertrand's dam was Eliza by imp Bedford. Eliza's dam was imp Mambrina whose dam was by Blank.

The best 2-mile time-3:43- made in the United States up to 1835 was said to have been made by GALLATIN (by imp Bedford), 3 years, in 1802; and by PEACEMAKER (by Diomed), 4 years, in 1804. See Turf Register, Vol. 7, p. 11.

Oft repeated entreaties by The Turf Register to the owners of SIR CHARLES for an account of his performances brought only a hand bill from which it appeared that he had run 26 races and won 20, 4 of which were of 4 -mile heats, 4 of 3-mile heats, 6 of 2-mile heats; in 6, distances not given. Of the races lost one was of 3-mile heats; distance of others not given. Hand bill did not state time in any instance. Sir Charles' dam was by imp Citizen; - by Commutation; - by imp Dare Devil; - by imp Shark; by imp Fearnought.

SALLY HOPE won $2 \mathrm{I}$ of 25 contests in one year. INDUSTRY, as far as known, ran 9 races and won all except his last in which he broke down. He was a horse of great speed and bottom and a fine sire. His dam was by Ball's Florizel, g. dam by Symmes' Wildair.

\section{D}

In a contribution to The Turf Register of July, 1832, one of its regular correspondents, "Panton," of Nashville, gave the names of some thoroughbred stallions said to have stood in Nashville or 
vicinity prior to 1809 . Five horses are mentioned as being there prior to 1800 . The first paragraph in the list is in these words:

“In 1788 b. h. Why NOT, son of Fearnought, brought from MaryIand to Tennessee, by General Robertson; very good."

Other horses prior to 1800 were, according to "Panton":

“' 1792, COMET (Lewis') by old Janus; good stallion. I792, JuPITER (Cross') by old Janus; good quarter racer. 1791-8, Weakley's Wildair, by Symmes' Wildair, out of a thoroughbred; very good stallion. Was exchanged to Kentucky, 1799, for Grey Alfred by Lindsay's Arabian, who stood a season or two and returned to Kentucky."

"Panton" does not give his authority for these statements.

Imp BARONET won for the Prince of Wales the Oatland stake at Ascot, I79I-92, I00 subs., I 00 guineas each. On this race the Prince took in 17,000 guineas.

From The Cartbage Gazette and Friend of the People, and from several Nashville papers, all in possession of the American Antiquarian Society of Worcester, Mass., the librarian, Mr. Clarence S. Brigham, has copied and sent names of stallions (with pedigrees as given in the advertisements), that stood in Tennessee in years not covered by papers on file in Nashville:

ALBORAK, by Truxton, dam by Maj. William Blackmore's old horse, Sterne; - by Pilgarlick, son of old Janus. Advertised by Richard Britten to stand season I8 I i on Middle Fork of Goose Creek; $\$ 4$ to $\$ 8$. Certificate by Reuben Cage.

ALPHEUS, by imp Jonah, dam Green's mare by Meade's Celer, etc., to Jolly Roger. Imp Jonah was by Escape, dam by Herod; - by Snap. In 1810, stood at John F. Moore's, Mill Creek, 5 miles from Nashville.

COLLECTOR, by Mark Anthony, dam by imp Centinel by Blank. Stood, 18ıo, at Absalom Page's, Eaton's Station, one mile north of Nashville. (Collector died in Davidson County in 1813. He was famous as sire of Snap-Dragon and Haphazard, Virginia horses.)

FORTUNATUS, ch. by imp Shark; dam by Celer; - by Capt. John Ware's Fearnought, of Goochland County, Virginia. In I804, advertised by P. W. Humphreys and John Faulkner, to stand three days each week at Maj. C. Stump's, four miles from Nashville on 


\section{Making the American Thorougbbred}

White's Creek; \$8; \$10. Advertisement of sweepstakes in same issue of this paper.

PANTALOON, by imp Pantaloon, dam Capt. Ewing's noted running mare, Kitty. Stood I8I I at Anthony Hogin's, Martin's Creek, Jackson County; \$10; \$20. Imp Pantaloon was by Herod; dam by Matchem, and was owned by Benjamin Harrison, signer of the Declaration of Independence, at his famous estate, Brandon, Virginia - or by a son of the same name.

PHENOMENON, by imp Diomed, dam by imp Master Stevens; - by Flimnap; he by imp Fearnought. Bred by Jourdan Reese, Dinwiddie County, Virginia. Season 1810 at Thomas Fowlkes', "on head waters of Dry Creek, two miles from Haysboro"; \$4 per leap.

PRESIDENT, by Goliah, dam by Dandridge's -; - by imp Janus; - by imp Traveller. Goliah by Tippoo Saib, dam by Blackburn's Why Not, son of imp Fearnought; - by imp Forester. Advertised by Simeon Buford, Season 1809. Advertised by James Hicks to stand in Franklin in 18 ro.

Buford, in advertising President in the Nashville paper, did not give his pedigree. As stated in the Carthage paper, and here shown, it is different from the pedigree given on page 52 of this volume from information obtained elsewhere.

WASHINGTON, by Comet, dam Pealon, by imp Black-andall-Black. Season 1809 at John and James Cochran's, mouth of Caney Fork River; $\$ 3$ to $\$ 12$.

YOUNG CELAH, by old Celah, dam a full blooded Eclipse mare (which Eclipse is not stated). Season 1809 at James Ware's, Goose Creek. Services: Single leap 3 barrels of corn; season, 10 barrels; to insure, 20 barrels.

YOUNG CYRON, by imp Cyron, dam William Stevenson's Arabian mare, Romping Nell. Imp Cyron by Florizel, sire of imp Diomed. Season 1810 at Morgan Williams', Carthage, and Soloman Blear's, Peyton's Creek. Services $\$ 4$ to $\$ 16$.

YOUNG DIOMED (pedigree previously given) was advertised in 1810 by John Elliott, of Brunswick County, Virginia, to stand that season at Holland's Ferry, 6 miles east of Columbia, Tenn.; \$4 per leap; $\$ 15$ to insure.

The pedigrees of Alborak, Collector and Young Diomed are the only ones above given that can be verified from stud books. Stud book compilers did not realize the extent of Massachusetts enterprise. 
Charges for services of these stallions were payable in all sorts of produce, including country linen, beeswax, saltpetre and whiskey.

\section{E}

LEXINGTON ran seven races, his only defeat being by his half brother Lecompte, in $7: 26-7: 38 \frac{3}{4}$, the best 4 -mile race to that time run in America. In a race against Lecompte's time of 7:26, on a wager of $\$ 25,000$ between the owners of the two horses, Lexington, at New Orleans, April 2, 1855, ridden by Gilbert W. Patrick, 103 Ibs. (3lbs. over weight), ran in $7: 19 \frac{3}{4}$, which remained the 4-mile record until his grandson, Fellowcraft, lowered it to $7: 19 \frac{1}{3}$, at Saratoga, in 1874 .

Lexington's dam, Alice Carneal, was by imp Sarpedon who was in the male line from O'Kelly's Eclipse, through King Fergus, Beningbrough, Orville and Emilius.

Just after the civil war, Lexington's get dominated the American turf nearly, if not fully, as much as Sir Archy's get did in their day. Two, especially, of Lexington's get - Asteroid and Kentucky were the sensations of their time. Both were grandsons of Glencoe, Asteroid being out of Nebula and Kentucky out of Magnolia. Asteroid ran only in 1864-5; won all of his twelve races; his winnings $\$ 12,800$. Kentucky, in five years, $1863-7$, inclusive, started 24 times and lost twice; his total winnings $\$ 35,950$. Both Asteroid and Kentucky were entered for the "Great Inauguration Stake," on the opening of Jerome Park, in October, 1866. Kentucky won the stake, but the result might have been different if Asteroid had not broke down in training.

Lexington was a blood bay, $15^{\frac{3}{4}}$ hands; all four feet white above the ankles; a large star; and a white stripe down his face, extending over the upper lip. According to Bruce "he was not only the best race horse America has ever produced, but the emperor of stallions." How Lexington would have fared in as many races as was run by Boston is mere conjecture. Boston's record being known, the author is inclined to agree with Busbey.

\section{F}

Of the stallions advertised in $1840-42$, inclusive, POST BOY continued at Murfreesboro during 1840-41. AMERICAN ECLIPSE was at James Swanson's, Williamson County, in 1840, and the next year at A. Whitlock's, Limestone County, Alabama. FOP stood 


\section{Making the American Thoroughbred}

at CoI. F. C. H. Miller's, Chapel Hill, in 1840 . In 1841 PICTON and imp VOLNEY were in Fayette County, and SHAKESPEARE in Davidson. In 1842 SHAKESPEARE was at Robert Hallum's, in Wilson County.

Among the new stallions introduced, $1840-1842$, were ROANOKE, by Sir Archy, dam by Cœur de Lion, who stood in Giles County; imp PUZZLE, by Reveller, dam by Juniper, who stood in Carter County; SHARK, by American Eclipse, dam Lady Lightfoot by Sir Archy, who stood at Independence, Williamson County; nine sons of Leviathan who stood in various sections; and two Arabians who stood at J. G. Smith's, Jefferson County. In I 842 imp PRIAM stood his first season in Tennessee, at L. P. Cheatham's, Robertson's Bend; service \$150. He died at Belle Meade in 1847. BAREFOOT, a St. Leger winner (by Tramp), imported into Massachusetts in 1828 , died from a snake bite at David Morrison's, Tipton County, Tennessee, in 1840. Three of his get, Clara Howard, Tramp and Ajax were prominent in Long Island stables. Imp CLARET, by imp Chateau Margaux, dam by Partizan, stood at William Y. Fuqua's, Bolivar, at \$1oo. His blood was rich in strains of Herod, Matchem, Eclipse and Snap. Claret was imported into Virginia in $\mathbf{1 8 3 4 .}$

\section{G}

The inducements offered certain sections of the United States to make use of the opportunities nature has put at their door is brought vividly to mind by Joseph Osborne's (English) Horse Breeders Hand book, $1889-90$. The author quotes another authority, Count Lehndorff, to the effect that the soil and climate of the United States "gradually restores the whole nature of the horse to its pristine vigor, and makes the American racer appear eminently qualified to exercise an invigorating influence on the constitution of the thoroughbred in the mother country, enfeebled, perhaps, by oft repeated inbreeding."

Osborne agrees with the author that the United States "appears the most promising recruiting ground for such purposes," and adds:

"The tendency to lose bone as they gain in general refinement, which becomes more conspicuous among the rank and file of our own thoroughbreds, might best be averted by a re-introduction of our old blood in new channels, from a land whose richness of herbage is so calculated to provide the Iacking quality. My own 


\section{Addenda}

observation tends to the conclusion that the finest bone comes as a rule from the best grass, which, it is well known, is raised on a limestone sub-stratum, after which that of the red sand stone has been reckoned the best. But though much of our own grass lands (particularly in Ireland) furnish good bone making material, they can scarcely compare in this particular with the wide plains of herbage in . . America . . Besides this, if I am to credit the opinion of keen observers of the young stock of America, added to those I have seen myself, bone and substance appear to be their distinguishing quality. And .... they have persistently progressed in the matter of speed."

This was written before it was known that some so-called "red sandstone" in this country was, in fact, phosphate rock, and that this bone-making phosphate enters, more or less, into all the grasses of the principal running-horse and trotting-horse counties of Middle Tennessee.

What could be made England's recruiting ground could, also, be made the recruiting ground of Continental Europe, which will be sadly in need of recruits at the close of the present war.

\section{$\mathbf{H}$}

Four pocket size stud books kept by Rev. Hardy M. Cryer, containing names of men who sent mares to Stockholder, Sir William, Arab and Luzborough, show more clearly than any other evidence the author has found, the wide extent to which the breeding of thoroughbreds prevailed among all classes, irrespective of occupation. Among the patrons of Cryer's horses were Rev. A. Martin who sent Twilight by Rifleman; Rev. Martin Clark, of the M. E. Church, who sent a sorrel filly by Conqueror; Rev, Fountain E. Pitts, of the M. E. Church, who sent a mare called Preacher; and Rev. Robert Paine, of the M. E. Church, who sent a mare by Stately.

Rev. Martin Clark lived in Rutherford County. Rev. Fountain E. Pitts was among the leaders in the church. Rev. Robert Paine - when he sent his Stately mare to Stockholder in 1827 - was Presiding elder of the Nashville District, and on his rounds from Duck river to Dover doubtless learned the necessity of having a horse that could "stay the distance." Doubtless his good steeds facilitated his good deeds and helped him to rise to the place of Bishop.

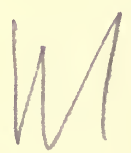




\section{Making the American Thorougbbred}

These stud books show that Cryer's horses were patronized by practically all the prominent breeders and turfmen named heretofore in this volume, from Andrew Jackson and John Catron, down, and by scores not mentioned. Among the unmentioned names that have a familiar sound to citizens of Davidson and adjacent counties are: Gallatin Donoho, William B. Lewis, Sam Bugg, Dr. Hobson, Jacob Gillespie, Dr. Tazewell Upshaw, A. H. Douglass, Joseph Lauderdale, Col. Woodfolk, Dr. Tim Walton, John Overton, Arch W. Overton, Bennett Douglass, Moses Ridley, John Carr, James House, Norvell Douglass, William H. Douglass, Dr. Franklin, Dr. Briggs, Thomas M. Hart, William Walton, Joseph Litton, William Hadley, Dr. Gentry and Capt. Gooch.

Under the head of "Lebanon Class," in one book, appear the names of Ben T. Motley, Col. Robert M. Burton, and others. Under the head "Murfreesboro Class" in one book appear the names of Charles Ready and others.

These entries show, also, that nearly all the mares were thoroughbred. An entry dated Oct. 3, I827, signed by O. Shelby and H. M. Cryer, dividing cash and accounts, shows that for Stockholder's services during that year they had already received $\$ 1,005$, and had $\$ 1,655$ coming to them. And Stockholder was only one among many.

\section{I}

At the Nashville Jockey Club's meeting, October, 1843, besides The Peyton Stake, The Cumberland Stake, \$3,670; The Trial Stake, \$9,000; The Alabama Stake, \$17,000; five other stakes aggregating \$1,970; and severaI Jockey Club purses, made up the program, the total amount of stakes and purses being more than $\$ 6 \mathrm{I}, 000$.

Of the 13 subscribers to The Cumberland Stake, for 2-year-olds, only two started: David Heinsohn's CONSUL, JR., by imp Consol, out of imp The Nun's Daughter by Filho da Puta, and Hugh John Kirkman's bay filly by imp Leviathan, out of imp Florestine by Whisker. This was a well contested race and was won in fine style by CONSUL, JR. Two-mile heats; time 4:16-4:12$4: 23$. The course "a hodge-podge of mud and water."

THE TRIAL STAKE. - The Trial Stake was run on the same day as The Cumberland Stake. This was a contest between 3-yearolds; 26 subscribers at $\$ 1,000$ each, half forfeit, or $\$ 250$ if declared by January $\mathrm{I}, \mathrm{I} 842$. Colts 86 pounds, fillies 83 pounds. Twomile heats. Three started. 
Col. Wade Hampton's b. f. MARGARET WOOD, by imp Priam, out of Maria West (Wagner and Fanny's dam) by Marion .................. Jas. Welcb.

Lucius J. Polk's (Geo. W. Cheatham \& Co.'s) ch. f. LIATUNA, by imp Ainderby, out of imp Jenny Mills by

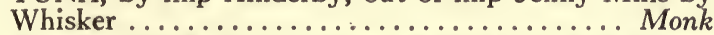
Col. Jo C. Guild's ch. f. by imp Leviathan, out of Proser-

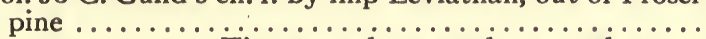
Time, $4: 04 \frac{1}{2}-4: 12 \frac{1}{2}-4: 17 \frac{1}{2}$.

3 I I

232

I 2 dist.

"The Priam filly was the favorite, but the betting was not very spirited. After several false starts they got off, the Leviathan filly cutting out the work with the favorite laying $2 \mathrm{~d}$. The Leviathan won the heat cleverly as Margaret Wood never made a stroke for it, and the Ainderby filly was unable to do more than force the running. After this heat the Leviathan filly had the call in the betting. Margaret Wood trailed to the last quarter, where she made a brilliant challenge, and after a prodigious brush won the heat on the post by half a neck only! In the $3 \mathrm{~d}$ heat Margaret Wood made all the running, and won by nearly a hundred yards."

Other nominations (all made in 1839 ) in this stake were:

James Jackson named produce of imp Gallopade and imp Glencoe. Samuel Ragland named produce of Preston's dam and Othello. Thomas Watson named produce of imp Pickle and imp Glencoe. Willis $\mathrm{H}$. Boddy named produce of Oscar's sister and imp Leviathan. L. P. Cheatham named produce of Isabella and imp Priam.

Wm. H. Polk named produce of imp Trinket and imp Ainderby. R. K. Polk named produce of Selia Burns and imp Ainderby. Nich. Davis named produce of imp Design and Count Badger.

E. H. Boardman named produce of imp Plenty and imp Consol. J. W. Camp named produce of Vanity and imp Leviathan. Hick. Lewis named produce of Salome and imp Luzborough. H. Dickerson named produce of Mary Smith and imp Leviathan. George Elliott named produce of Hibernia and imp Leviathan. than.

Samuel Ragland named produce of Othello's dam and imp Levia-

Alex. Barrow named produce of Lilac and imp Glencoe.

T. Kirkman named produce of imp Gutty and imp Glencoe.

Wm. Wynn named produce of Victoria and Picton.

E. H. Boardman named produce of Sarah Bell and imp Consol. Isaac Lane \& James Jackson named produce of an Aaron mare and imp Glencoe.

Also Isaac Lane \& James Jackson named produce of Harriet and imp Glencoe.

Thos. T. Hurt named produce of Blackbird and imp Ainderby.

W. Hampton named produce of Bay Maria and imp Priam.

John S. Corbin named produce of imp My Lady and imp Priam. 


\section{Making the American Thorougbbred}

Two Consuls, 4 Priams, 4 Ainderbys, 6 Leviaathns, 6 Glencoes; the other sires one each.

THE ALABAMA STAKE. - The best race of the three great events was The Alabama Stake, for 4-year-olds; colts 100 pounds, fillies 97 pounds. Fifteen subscribers at \$2,000 each; half forfeit or $\$ 500$ if declared by January $1,184 \mathrm{I}$; the second horse to receive back his stake. Three-mile heats. Three starting.

Lucius J. Polk's (Geo. W. Cheatham \& Co.'s) ch. c. AMBASSADOR, by Plenipotentiary, out of imp Jenny

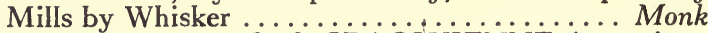
Thomas Kirkman's ch. f. CRACOVIENNE (own sister to Reel), by imp Glencoe, out of imp Gallopade by

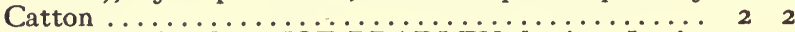

Capt. N. Davis ch. c. JOE BRADLEY, by imp Leviathan - imp Design by Tramp.............. dist. Charles Bosley's \& Henry M. Clay's gr. f. by imp Philip, out of Gamma's dam by Sir Richard ............ dist. Time, 5:59-5:54. Track tough and heavy.

"Our reporter," said The Spirit of the Times, "writes that this was one of the best races he ever witnessed. The Glencoe filly, Cracovienne, (sister to Reel, Waltz, Fandango, and Cotillion,) was the favorite at 2 to I against the field. She went off with the lead and maintained it for three quarters of a mile, when Ambassador challenged and passed her at quarter horse speed. Indeed Monk could not restrain him, and at the close of the ist mile he led the field fifty yards! At the close of the $2 \mathrm{~d}$ mile Joe Bradley was in difficulty, and the Philip filly already out of her distance. On the Iast quarter Barney brought up Cracovienne, but finding he could not reach Ambassador, he pulled up and fell just within his distance, while the other two were no wherel Joe Bradley was distanced by about two lengths, while Gamma's half sister was beaten into fits. The prejudice against the Plenipo stock served to keep Cracovienne the favorite, notwithstanding the show she made in the 1 st heat. In the $2 \mathrm{~d}$, she made several ineffectual efforts for the lead, which merely demonstrated the colt's superiority, as he was never caught, and won by 50 yards!"

Other nominations in this stake were:

James Jackson named ch. c. by imp Glencoe, out of Waxlight.

Maj. Samuel Ragland named b. f. by imp Glencoe, out of Othello's dam.

R. K. Polk named b. f. by The Colonel, out of imp Pledge.

E. H. Boardman named b. f. by imp Consol, out of imp Woful. 


\section{Addenda}

W. H. Polk named ch. c. by The Colonel, out of imp Trinket.

Jesse Cage named gr. f. by imp Leviathan, out of Fanny Maria.

Col. Geo. Elliott named ch. c. (bro. to Sarah Bladen) by imp Leviathan - Morgiana.

Geo. W. Polk named ch. f. by Glaucus, out of imp Primrose.

Col. J. W. Camp named ch. c. by imp Luzborough, out of Sally Dancey.

Oliver Towles named ch. c. by imp Leviathan, out of Molly Long. Col. Wm. Wynn named b. f. by imp Priam, out of Flirtilla Jun.

Two The Colonels, 3 Glencoes, 4 Leviathans; the other sires one each.

Among sires of nominations to both The Trial and The Alabama Stakes, note the predominance of imported blood; also note that American Eclipse, who lived until 1847, had no get among the entries.

\section{$\mathrm{J}$}

Walter O. Parmer, who came from Greenville, Alabama, to Tennessee, in $188 \mathrm{I}$, inherited from his father, Dr. C. D. Parmer, and his grandfather, Col. Ephraim Parmer, a love for the thoroughbred, and has been all his life an ardent devotee of the turf. Despite adverse legislation he has maintained the Iargest breeding establishment in the state since the passing of Belle Meade. At the dispersal of this famous stud, Mr. Parmer purchased The Commoner and about twenty of the best mares, and established them at Edenwold. Since then he has continually added mares of choicest breeding and superior individiual qualties, his latest additions of this character being 16 mares recently imported from England. His brood mares now number about 60, among them the dams of Roamer, Great Britain, Notasulga, Hessian, Johnny Blake and other noted racers.

After the death of The Commoner, in 1914, Mr. Parmer imported from England the richly bred Assagai, who is now the premier stallion at Edenwold.

Edenwold is a beautifully situated farm, easily accessible by all means of conveyance, and no visitor has to halloa at the front gate more than once to bring a cordial greeting from the hospitable proprietor. 



\section{INDEX}

American Bible Society gets North and South Matches, race winnings, 132

American Turf Register, I5-17

English Stakes, The Derby, The Oaks, The Doncaster St. Leger, I0, I I

Four-mile runners, signs of disappearance, 12, 17

Height of famous horses, 33

Importations, opposition to, 63 , 67; results of opposition, 77 , $8 \mathrm{r}, 82$; results to Tennessee stock, 72

Importations into Tennessee, 93; into Alabama, 127

Jockeys, noted, Gil Patrick, 6r, 169; Samuel Purdy, 156, 162, 262; Willis, 169, 172; Arthur Taylor, 61, 158, 173; Green Berry Williams, 178 , 232-8; Monkey Simon, 2502, 268-270

Mares, imported, before and after Revolution, 33, 34; in Tennessee, 92

Match races, methods of arranging, 13,14

Names of horses reflected events of times, is

North Alabama Breeding Establishments, 124-28, 165, et seq. origin, 151; how score stood in 1834, 153; in 1845, 208; excitement over, 155, 157, 1 59, 161, 169, 182, 210,211

Pedigrees, how preserved before days of stud books, 16

Prices for young stock and for service of stallions, comparisons, 94, 95

Purses, size of, 12

Races, in Virginia, before Revolution, 4; after Revolution, 232, et seq.

Races, popular interest and excitement aroused, I55, I57, I6I, I69, I77, I82, I87-190, 198-200, 2 I 0, 2 I I

Race courses, natural outgrowth of conditions, 4 ; number in U. S. in 1839, 9; absolutely necessary, 3

Racing districts, 12

Spirit of the Times, The, 15-17 Stallions, number of in U. S. in 1839, ro; rank of, 66-73; native and imported, comparisons, 66,68

Stallions of 1883 , tracings of to Sir Archy, American Eclipse, Glencoe, Leviathan and Luzborough, 82,83 
Stallions in Tennessee, between I 788 and 1800, 42-4, adn. D; between 1800 and 1810 , 44-53, adn. D; between I 810 and 1820, 53-58, adn. $D$; between 1820 and 1830 , 58-65; between 1830 and 1840, 73-92; subsequent to I 840,93 , adn. F

Sumner County, her pioneer breeders and foundation stock, 96-113; celebrated produce, IOI-II2; produced first 3year old in U.S. to sell for as much as $\$ 8,000$; her breeders and stock of later period, I I 2-1 20

Tennessee, adaptability to raising horses, 1, 96; English writer's opinion, adn. G; her horses of same families as English horses of same period, 10-1 2, 72, I66, 197, 198, adn. B, adn. I; supply depot for Southern States, 7, 8, I7, 104-I10; all her horses descendants of three English corner stones, 43,44 .

Thoroughbred, origin of, 18 ; live lines of descent, 23-9; modern illustrations of these lines, 93, 94

Thoroughbred, his contribution to development and material interests of South, 8; his influence on customs and habits of the people, $1-5,70$; his adaptability to war, 5 ; his influence on other blood stock industries, 8, 9, 17; moved
Westward with star of empire, 5; and beat the Constitution to Tennessee, 42,43 , adn. B Time, best 4-mile up to 1874 , adn. $\mathrm{E}$; average running in 1838,27 ; best 3 -mile up to I835, adn. C; results from improved tracks, 263

Trainers, noted, Sidney Burbridge, I76, I78; A. L. Hammond, 166, 172; Arthur Taylor, 6I; Green Berry Williams, see Jockeys; Capt. John Belcher, 6I

War, 186 $1-6_{5}$, effect of on thoroughbred industry, 84; comparisons, 83, 94, 95

\section{Noted Races in addition to those mentioned in "CONTENTS"}

Angora and several competitors, 182

Argyle and John Bascombe, I 66 Ariel and Flirtilla, 208

Bertrand, Aratus and Creeping Kate, adn. C

Boston and Fashion, 208

Boyd McNairy, Picton and Osceola, I9I

Doublehead and Expectation, 245

Greyhound and Tanner, 242

Greyhound and Truxton, 24I, 245,246

Haynie's Maria and many competitors, 258

Hiawatha and Mary WyIlie, I 17 
Polly Medley and Indian Queen, 239-40

Ploughboy and Truxton, 38-50, 242

Sir Henry Tonson and several competitors, 103

The Alabama Stake, at Nashville, adn. I

The Barry Sweepstake, at Gallatin, I I I

The Cumberland Stake, at Nashville, adn. I

The Trial Stake, at Nashville, adn. I

Wagner and Grey Eagle, I 2

Walk-in-the-Water and various competitors, 254-5

Tennessee Jockey Clubs, Race Tracks and Race Meetings

Bean's Station, I 28, 148

Bledsoe's Creek, I30

Bolivar, 128, 145

Cage's Bend, 262

Cairo, 102, 22 I

Clarksville, 128, 133, 144

Clover Bottom, 128

Columbia, 128

Cryer's, 98

Dresden, 128, 134

Fayetteville, 128, I30

Franklin, 128, 130, 133, 14 I

Gallatin, 128, 130, 134-141

Goose Creek, 248

Hartsville, 128, 134

Jackson, 1 28, 134
LaGrange, 128, 134

Madisonville, 18,128

Mansker's Creek, 130

McMinnville, 128, 145

Memphis, 128, 147

Mt. Pleasant, 128, 133, 142-4

Murfreesboro, 128, 133, 145

Nashville, 128, 130, 131, 134

Paris, 128, 133, 134

Petersburg, I 28, 134

Pulaski, 128, I30

Red Bridge, $18,128,148$

Shelbyville, 1 28, 130

Somerville, 128,146

Wilson County, 130

Winchester, I 28, 133

Some of The Notables

Ainsworth, William, 14, 91

Alderson, Thomas, 84-6, 90

Alexander, W. L., 88

Barry, R. D., 97, 240

Barry, Thomas, $84,87,88,114$, I84, I87, 191

Bell, Montgomery, 63, 122

Burford, David, 88

Cage, Jesse, I19, 201; his horses, 120

Cage, Reuben, 5 I

Campbell, Colin, 64

Cannon, Newton, 245, 268

Carrick, S. V., 90

Carroll, Gov. William, 57, 123 , I3 I, 268

Cheatham, L. P., 78, 79, 87, 89, I20, 20I, adn. F

Childress, John, 56, 262

Claiborne, Thomas, 85 
Clark, Rev. Martin, 90, adn. H

Clay, Henry, 5, 179

Cockrill, M. R., 9

Coleman, Joseph, 5 I

Cook, Henry, 88

Cook, Hal., 90

Cotton, Arthur, 88

Cryer, James, 87, 97, 98

Cryer, Rev. Hardy M., 15, 79, $85,86,87,89$, 91, 100, II416, $184,187,266$; his letters from Jackson, 27I; lists of those who patronized his stallions, adn. $\mathrm{H}$

Davie, A. J., 39, 48, 122

Desha, Robert, I, 92, 175

Donelson, A. J., 89, 166, 167, 243

Elliott, George, 54, 56, 64, 67, $76,88,89,9$ 1, 98, 100, 127, 250, et seq., 267, 269, 273

Elliston, Joseph T., 64

Ewing, Alex, 55, 57, 64

Foster, Robert C., 51, 53, 57, 270

Foxhall, Thomas, 87, 116

Gordon, Francis, 88

Gowen, W. B., 8 5

Guild, Jo C., 87; his horses, I 08,117

Harding, John, 57, 63

Harding, W. G., 3, 6, 63, 121; his horses, 121

Heiskell, F. S., 90

Hooper, I., 52

Hurt, Rev. Robert, 86, 87, I 23

Jackson, Andrew, his account of Truxton-Ploughboy race, and his advertisement of Truxton, 48; advertises Pacolet, 55; Young Truxton, 64; Bolivar, 87; tradition as to his riding races, 98; how he was like Col. W. R. Johnson, 154; his methods of training, 166; turf activities while president, $167,243,274$; at Gallatin races, 240,248 ; at Hartsville races, 241, 245; at Clover Bottom, 246, 249; efforts to beat Haynie's Maria, 55, 259, 260; his knowledge of governmental affairs and horses compared, $18 \mathrm{I}$; "sassed" by Monkey Simon, 269; his letters to Rev. H. M. Cryer, 271-4; his quarrel with Newton Cannon, 247; his opposition to race suicide, 125, 126; his orders to Van Buren, Balie Peyton and others, 243, et seq; one of promoters of Nashville Jockey Club, 268

Jackson, James, 9, 56, 67, 76, $88,124,184,268$

Jefferson, Thomas, 5, 35, 38

Johnson, William R., 39, 55, 60, 6I, 104, I5 I, 167

Kirkman Brothers, 92, 126

Kirkman, Hugh, 138, 139, 140

Kirkman, John, 212

Kirkman, Thomas, 201

Lee, Gen. H., 35

Lewis, Joel, 52

Mabry, J. A., 90, 107, 1 18, 179

Martin, Rev. A., adn. H

Martin, Thomas, 9I, adn. A 
McGavock, D., 50

McNairy, Dr., 57, 268

Miller, F. H. C., adn. F

Murray, Ennis, 86

Newsom, A. B., 59, 89, I0 I, 108

Nolen, A. T., 86, 89, $16 \mathrm{r}$

Page, Absalom, adn. D

Paine, Rev. Robert, adn. H

Parmer, Walter O., 45, 94, adn. J

Peyton, Balie, 84, 86, 108, II I, 179, 192, 199; his horses, 118 , I19

Peyton, R. H., 89, II 9

Peyton, W. R., II9

Phillips, Joseph, 50

Phillips, W. D., 65

Pillow, William, 85

Pitts, Rev. Fountain E., adn. $\mathrm{H}$ Polk, L. J., 84, 85, 92, 122, 188, 192

Polk, R. K., 92

Polk, George W., I 13

Randolph, John, 5; at EclipseHenry race, 159; his tribute to Samuel Purdy, 162; Green Berry Williams' opinion of, 236 Robertson, James, 45, adn. D

Sappington, Dr. Roger B., 58 , 266 , et seq.

Saunders, Rev. Hubbard, 55, $84,85,99$, I00, 116

Saunders, W. R., 91

Scruggs, James, 14, 148

Shelby, Dr. John, 57, 268, 269

Shelby, Orville, 58, 65, 97, 99, adn. $\mathrm{H}$

Shute, John, 52, 57, 63

Sumner, Duke W., 86, 90, 92, 124
Swanson, James, 73, adn. F

Tayloe, John, 33, 35, 36, 39

Ward, Edward, 53

Washington, George, 5, 35, 228

Weakley, Robert, 51, 53, 122, adn. D

Williams, William, 51, 52-6,

131, 268; his horses, 120

Wyllie, Geo. A., 76, I 12

Yourie, Alex P., I12, 19 I

Material References to Important Horses

Actaeon, 93, adn. B

Ainderby, 7I, 84

Albion, 93, 113 , adn. B

Alborak, adn. D

Alcaster (or Akaster) Turk, 19

Alcock Arabian, 19

Alpheus, adn. D

Amanda, 38, 237

Ambassador, 93, adn. I

Andrew Jackson, 89

Angora, 105, 107, 177, 182

Anvil (Herod), 33

Anvil (Mons Tonson), 84

Anvilina, 33

Apollo, 32

Arab, 84

Ariel, 74, 85, 208

Argyle, I04, 166

Aristotle, 32

Arminda, 36

Atalanta, 109, 118

Augusta, 34

Autocrat, 71, 84

Babraham, 23, 28, 32-5, 37

Bagdad, 63

Bald Galloway, 22, 23, 30 
Barefoot, adn. F

Baronet, 50, adn. D

Bashaw, 57

Basto, 20, 22

Bay Diomed, 64

Bedford, 38, adn. C

Beeswing, I0 I, 108

Behemoth, 84

Bellair (Cook's), 57

Bellair (Medley), 37

Bellair (Sir Archy), 89

Belgrade Turk, 19, 34

Belshazzar, 84, 277

Belsize Arabian, 32

Beningbrough, 29, 75

Bertrand, 40, 69-73, adn. C

Betsey Malone, 105, 253

Betty Leedes, 2 I

Betty Percival, 37

Big Quicksilver, 5 I

Birmingham, ro , , 106

Black-and-all-Black ley's), 122

Black Maria, 74, 109, 194, 199

Black Sophia, 100, 101, 130

Blank, 22, 24, 28, 37, adn. C

Blaze, 21, 22, 33

Blazella, 33

Bloody Buttocks Greyhound, 31

Bloody Flag, 5 I

Blossom, 31, 265

Bluster, 63

Boaster, 57

Bolivar, 38, 87, 273

Bolivia, I67, 243-5

Bompard, 52; see also 24I

Bonnets O'Blue, 209

Bosphorus, 28, 39

Boston, 61, 69-73, 109, 208, 237. adn. C
Boyd McNairy, I 10

Brilliant, 43

Brimmer, 19, 26, 30, 31

Brimmer (Clubfoot), 43

Brittania, 34

Brownlow Turk, 22

Bryan O'Lynn, 57

Bucephalus, 53

Buoy, alias Buford's Defeat, 51, I00

Burrampooter, 50

Busirus, 243

Buzzard, 24, 90, 166, adn. B

Byerly Turk, 20, 23

Cade, 22-4

Cade (Fearnought), 5 I

Cain, 93, adn. B

Careless, 21, 23

Careless (Regulus), 28

Carolinian, 85

Cartouch, 19, 33

Castianira, 39

Celer, 3 I

Champion, 100, 24I

Chanticleer, $5 \mathbf{I}$

Chatham, 38

Chatham, 43

Cherokee, 40

Chesterfield, 89

Childers (Bartlett's) 20, 22, 23, 34

Citizen, 55, 56

Citizen (Stockholder), 89

Claret, adn. F

Clockfast, 6I, adn. C

Cock of the Rock, 88

Cour de Lion, so

Collector, adn. D

Commutation, 32

Comus, I I 3 , adn. B 
Conductor, 26, 34, adn. B

Conqueror, 57

Constitution, 63

Contention, 38

Coronet, 89

Cost Johnson, I 19

Count Badger, 89

Crab, 19, 24, 28, 31, 32, 37, 39

Cramp, 89

Crawler, 50

Cripple, 22, 34, 36

Crusader, 85, 274

Cullen Arabian, 28, 32, 34

Cumberland, 64

Curwen's Bay Barb, 19, 23

Cygnet, 24

Daniel O’Connell, 109

D'Arcy Royal Mare, 24

D'Arcy White Turk, 26

D'Arcy Yellow Turk, 19

Dare Devil, 50, 237

Darley Arabian, 19, 20, 23

Delpini, 84

Dick Andrews, 78, 84

Dimple, 23, 32

Diomed, 37-9, 166

Diomed (Ragland's), 53

Diomed (Second), 53

Diomedon, 53

Dismal, 22, 23, 32

Don Quixote, 28

Dormouse, 22, 23, 33

Doublehead, 50

Dragon, 57

Dragon (Cage's), 5 I

Dungannon, 28, 38

Dungannon (Bradley's), 259

Dungannon, imp, 52

Duroc, 38, 73
Eagle, 38, 63

Eclipse, American, 68, 69-74, 82, adn. F

Eclipse (by Hall's Eclipse), 5 I

Eclipse (Hall's), 28, 38

Eclipse (Harris'), 32, 120

Eclipse (O'Kelly's), 21, 23, 26, $27,29,33,34$

Eleanor, 75,78

Election, 85, 90

Emilius, 75

Emu, 93

Espersykes, 93

Fanny Bell, I Io

Favorite, 34

Fearnought, 32, 120

Fearnought (Dandridge's), 32

Fitz-Medley, 5I

Fitz-Partner, 31

Flint, 89

Flirtilla, 34

Flirtilla (Sir Archy), 40, 6r, 208

Florizel, 24, 37

Florizel, alias Greytail, 57

Florizel (Ball's), 38, 48, 6I, 236, 237

Flying Childers, 20, 21, 25, 27, 33

Fop, 85, adn. F

Fortuna, I0I

Fortunatus, adn. D

Fox, 20, 22, 23, 30, 33

Frozenhead, 89

Gallatin, 53, 54, adn. C

Gamma, 12 I, 24 I

Gander, 87

Gaston, 89

Giles Scroggins, 85

Gimcrack, 36, adn. C

Gimcrack (Medley), 36 
Glencoe, 69-73, 79, 82, 195, Jackson, 57 adn. B

Glenroy, 89

Godolphin Arabian, 19-24

Gohanna, 29

Gohanna (Sir Archy), 40

Gold Boy, 89

Gower Stallion, 23, 33

Gracchus (Randolph's), 32

Great Britain, 94

Gresley's Arabian, 32

Grey Archy, 89

Grey Diomed (Barksdale's), 52

Grey Diomed (imp Diomed), 38

Grey Diomed (imp Medley), 38, 73

Grey Eagle, 69-73, I 12

Grey Grantham, 22, 37

Grey Medley, 44, 240

Grey Robinson, 22

Gun Powder, 90

Hautboy, 26

Havoc, 90

Helmsly Turk, 19, 32

Henry, 38, 40, 74, 155, 159

Hephestion, 90

Herod, imp, 52

Herod, or King Herod, 23, 24, $28,33,34$

Hiawatha, I17, I1 8

Highflyer, 24, 25, 29, 34, 38

Highflyer (Wildair), 32

Highlander, 90

Highlander, imp, 52

Hortensia, I 10

Hugh Lawson White, 90, 107

Imperator, 26, adn. B

Industry, 40, I 18 , adn. C

Isabella, 40, 83

Janus, 22, 28

Janus, imp, 30, 120

Jefferson, 88

Jenny Cameron, 33

Jenny Dismal, 32

Jerry, 88 , Ior

Jigg, 20, 23, 33

Jim Polk, I Io

Joe Andrews, 78

John Dawson, 88

John Malone, I Io

John Richards, 40, 154

Jolly Roger, 30, 33

Juniper, 32, adn. C

Justice, 32

King Fergus, 28, 75

King Herod (Fearnought), 32

Kitty Fisher, 33

Kosciusko, 40

Laburnam, 43

Lady Lightfoot, 40, 60

Lady Nashville, 167, 245

LaFayette, 90

Lap Dog, 88, 183

Lath, 22, 23

Lavinia, 109

Layton Barb Mare, 3I

Leadall, 43

Leedes' Arabian, 20, 37

Leviathan, 4, 8, 69-73, 75, 82, 112,184 , adn. F

Leviathan, Jr., 90

Lexington, 62, 237, adn. E

Lindsay Arabian, 34

Linnet, 106

Lottery, 90

Lurcher, 90

Luzborough, 4, 70, 7I, 78, I84, 195 
Macedonian, 90

Madam Bosley, 124

Madam Tonson, 100, II5

Madison, 38

Magnolia, 35

Makeless, 20, 24, 30, 31

Mambrino, 89

Manuella, 84, 85

Margrave, 71, 85

Maria (Haynie's), 264

Maria Shepherd, I 18, 194

Marion, 40

Mark Anthony, 31

Marlborough, 35

MarshaI Ney, 89

Marshall, or Sellaby, Turk, I9

Marske, 23, 33, 35, adn. B

Mary Gray (Roundhead), 33

Mary Gray (Tippoo Saib), 24 I

Matchem, 23, 25, 29, 34

Matchless, 22

Matchless (Fearnought), 32

Matilda, 124

Medley, 32, 36, 37, adn. C

Medoc, 4, 69-74

Melli Melli, 90

Melzar, 36

Mercury, 27

Mercury (Sir Archy), 90

Merman, 89

Merry Tom, 32

Messina, 57

Mingo, 74

Mons Tonson, 72, 100, 101, 241

Montagu (old), 26

Monticello, 38

Mordecai, 90

Morgiana, ror

Mucklejohn, 40

Muley, 75,85 , adn. B

Muzzle Diomed, 63
Nancy Bywell, 34

Napoleon, 64

Narcissa Parrish, I 10

Nashville, 64

Obscurity, 28, 86

Oglethorpe Arabian, 20

O'Kelly, 85

O'Possum Filly, 87, 88

Orphan Boy, 9I

Orville, 75

Oscar (Tennessee), 57, 266

Othello, alias Black-and-allBlack, 28, 31, 32, 35

Pacific, 86, 193

Pacolet, 33

Pacolet (Citizen), 55, $24 \mathrm{I}$

Paget's Turk, 37

Pantaloon, imp, 34, 83

Pantaloon (imp, Pantaloon) adn. D

Papillon, 25

Parasol, ror

Partner (Croft's), 19, 22, 23, 25, 30, 31, 36, 37

Partner (Morton's Traveller), 3 I

Partnership, 91

Peacemaker, 64, 237, adn. C

Pegasus, 28, 34, 63

Peggy, 34

Phenomenon, adn. D

Philip, 86

Phoenix, 58

Picton, 83,185 , et seq., adn. F

Pirate, 40

Place's White Turk, 19, 3 I

Plenipotentiary, 75, adn. B

Ploughboy, 45, 241

Post Boy, 83, adn. F

Pot8os, 28, 34, 87, 88, adn. B

Potomac, 38 
President, 52, adn. D

Priam, I1, 12, 69, 73, 75, adn. B, adn. F

Priam (imp Leviathan), 91

Prince, 34

Puzzle, adn. F

Queen of Trumps, 100

Quicksilver, 36

Rachel, 24

Rainbow, 43

Ranter, 32

Ratler (Thornton's), 86

Raven, 43

Reality, 40, 60

Regulus, 22, 24-6, 28, 31, 32

Regulus (Fearnought), 32

Roanoke, adn. F

Robin Adair, 91

Robin Hood, 91

Robin Redbreast, 34, 86

Rockingham, 25, 39

Rockingham (Partner), 3 I

Rodney, 52

Romulus, 91

Roundhead, 22, 30, 33

Rosey Clack, 99, 100

Rowton, 93, adn. B

Royal Barb Mare, 24, 32

Royalist, 50

Roxana, 22

Rubens, adn. B

Sacklowie, 93

Sally Gee, 40

Sally Hope, 40, adn. C

Saltram, 28, 34

Sampson, 2 I

Sarah Bladen, 105, 185, 253

Saxe Weimer, 91

Scota, 28, 84

Scythian, 93
SeagulI, imp, 34

Sea Gull (Sir Archy), 40

Second, 22, 33

Selim, 24, 79, adn. B

Selim (Othello), 32

Selima, 35, 37

Shakespeare, 86, adn. F

Shamrock, 93, adn. B

Shark (American Eclipse), adn. $\mathrm{F}$

Shark (Marske), 35, 38

Sir Alfred, 38

Sir Andrew, 91

Sir Archy, 38, 39-41, 66-9, 82, adn. C

Sir Archy, Jr., alias Montorio, alias, Out-of-Transport, 40, 176

Sir Arthur, 40

Sir Charles, 36, 40, 41, 69-73, I 8 , adn. C

Sir Harry, 64

Sir Henry Tonson, 87, 100, 103 , $24 \mathrm{I}$

Sir James, 64

Sir Richard Tonson, 87, Iо0, 103, 24 I

Sir Peter Teazle, 25, 28, 34, adn. B

Sir Peter Teazle (Sir Peter Teazle), 34

Sir William (Clay's), 64

Sir William-out-of-Transport, 40

Sir William (Richardson's), 64

Skylark, 9I

Skylark, imp, 87

Sloe, 28, 31, adn. B

Smolensko, 86

Snake, 19,23, 26

Snap, 22, 28, 34, 36

Snap, imp, 34 
Snip, 22

Snipe, 34

Soothsayer, adn. B

Sorcerer, 87, 93, adn. B

Soreheels, 19, 22, 24

Sour Crout, 50

Sovereign, 69-73

Spadille, 34

Spanker, 19, 23, 37

Spanking Roger, 22

Spark, 3 I

Spectator, 37

Squirrel, 19, 26

Squirt, 19, 23

Star, 34

Starling, 34

Sterling, 32

St. George, 34

St. Giles, 9 I

St. Patrick, 93, adn. B

St. Paul, 34

St. Victor Barb, 22

Stockholder, 58, 27 I

Straddling, or Lister, Turk, 19

Strickland Turk, I9

Stumps, 93, adn. B

Stump-the-Dealer (Bryan

O'Lynn), 58

Stump-the-Dealer (Diomed), 38

Sultan, 24, 79, adn. B

Sumpter, 40

Sweeper, 28

Swiss, 92

Talleyrand, 9 I

Tariff, 40

Tartar, 23, 27, 28, 33, 34

Telegraph, 9 I

Teneriffe, 93

The Poney, 108

Thoulouse Barb, 19
Timoleon, 59

Tobacconist, 9I

Top Gallant, 53

Tramp, 79, 91, adn. B

Traveller, 13, 9 I

Traveller (Morton's), 3 I

Trentham, 39

Trifle, I09, 118

Trumpator, 26, 34, 87, adn. B

Trustee, 69-73

Truxton, 48, 241, 242

Tup, 53

Vampire, 32

Vanity, 40

Velocipede, 84, adn. B

Vertumnus, 28, 34

Ving'tun, 92

Virago, 28

Virginia LaFayette, 40

Virginian, 36, 40

Virginius, 38

Volante, 34

Volney, 93, adn. F

Volunteer, 27, 34, 58, 63

Volunteer (Volunteer), 53

Wacousta, 92

Wagner, 69-72, I I 2

Walton, 92

Warlock Galloway, 39

Washington (Comet), adn. D

Washington (Pacolet), $6_{5}$

Waxy, 88

Whale, 87

Whalebone, 87, 88

Whisker, 88, 92

Whiskey, 63, adn. B

Whynot, 32, 45, adn. D

Wildair (Symmes'), 32

Wildair (Weakley's), 53, adn. D

Wild Bill, 87 
Wonder (Wilkes'), 54

Woodpecker, 24, 29, 34

Woodpecker (Bertrand), 4, II 166

Young Cade, 38

Young Celah, adn. D

Young Cyron, adn. D

Young Diomed, 52, adn. D

Young McKinney Roan, 52
Young Medley, 36, 65

Young Northumberland, 43

Young Sir Charles, 92

Young St. George, 43

Young Truxton, 64

Young Virginian, 92

Young Wonder, 65

Zamor, 92

Zelina, 107 



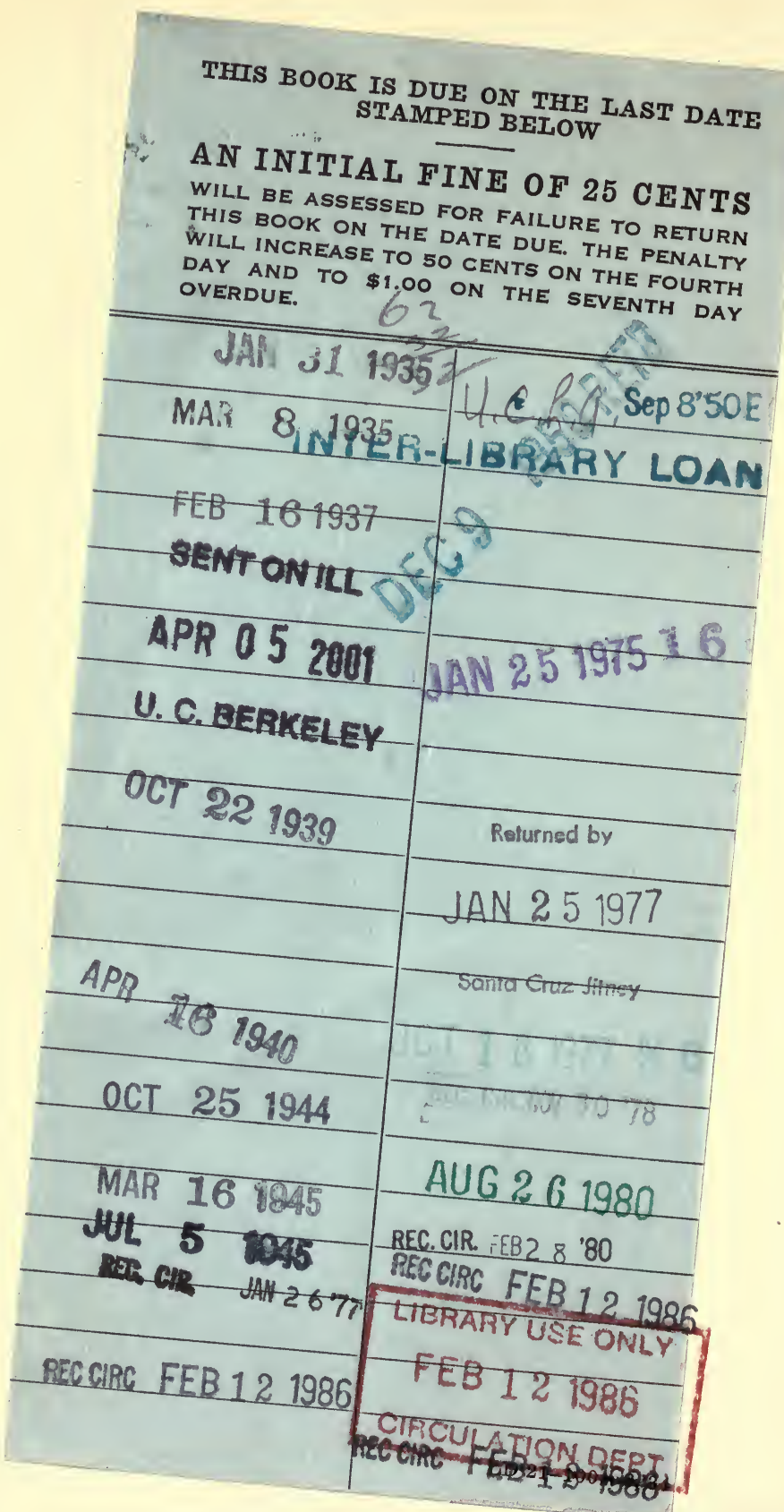


$\pm \therefore \therefore$.

696611

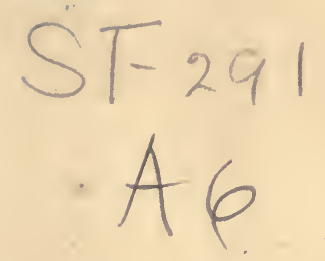

UNIVERSITY OF CALIFORNIA LIBRARY

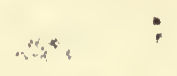


$=\pi$ 의

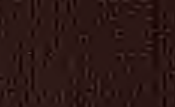

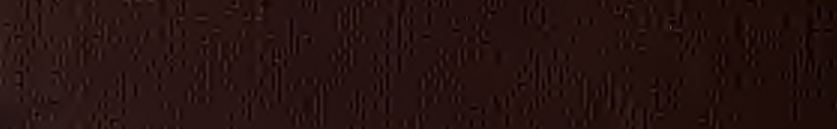

年

等

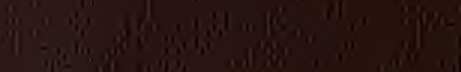

|

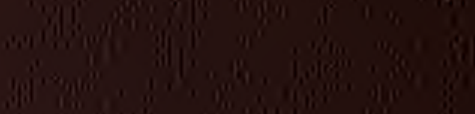

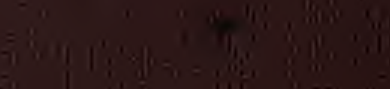
this

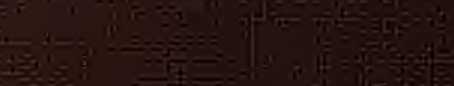

\&올요 i:

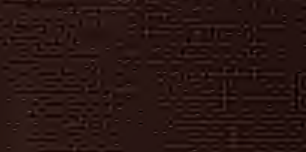

-ring

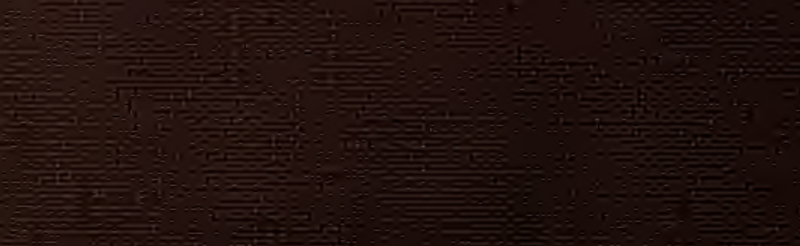

